Universidade de São Paulo Faculdade de Arquitetura e Urbanismo

\title{
A RAZÃO E OS LIMITES DAS POLÍTICAS NACIONAIS DE DESENVOLVIMENTO URBANO uma análise comparativa das proposições de 1975 e 2004
}

Marise Tissyana Parente Carneiro Adeodato 
Universidade de São Paulo Faculdade de Arquitetura e Urbanismo

\section{A RAZÃO E OS LIMITES DAS POLÍTICAS NACIONAIS DE DESENVOLVIMENTO URBANO uma análise comparativa das proposições de 1975 e 2004}

Marise Tissyana Parente Carneiro Adeodato 
Marise Tissyana Parente Carneiro Adeodato

A RAZÃO E OS LIMITES DAS POLÍTICAS NACIONAIS DE DESENVOLVIMENTO URBANO: uma análise comparativa das proposições de 1975 e 2004

Tese apresentada à Pós-graduação da Faculdade de Arquitetura e Urbanismo da Universidade de São Paulo, para obtenção do Título de Doutor.

Área de Concentração: Planejamento Urbano e Regional

Orientadora: Profa ${ }^{\underline{a}}$ Dra. Maria Lúcia Refinetti Martins Rodrigues

São Paulo 2010 
AUTORIZO A REPRODUÇÃO E DIVULGAÇÃO TOTAL DESSE TRABALHO, POR QUALQUER MEIO CONVENCIONAL OU ELETRÔNICO, PARA FINS DE ESTUDO E PESQUISA, DESDE QUE CITADA A FONTE.

E-mail: tissyana@yahoo.com.br

Adeodato, Marise Tissyana Parente Carneiro L533d A razão e os limites das Políticas Nacionais de desenvolvimento urbano: uma análise comparativa das proposições de 1975 e 2004/ Marise Tissyana Parente Carneiro Adeodato. - São Paulo, 2010.

301p.: il.

Tese (Doutorado - Área de Concentração: Planejamento Urbano e Regional - FAUUSP.

Orientadora: Maria Lúcia Refinetti Martins Rodrigues

1.Política Nacional de Desenvolvimento Urbano. 2.Políticas Urbanas. 3. Planejamento Urbano. I. Título. 


\section{FOLHA DE APROVAÇÃO}

Marise Tissyana Parente Carneiro

Adeodato

A Razão e os Limites das Políticas

Nacionais de Desenvolvimento

Urbano: uma Análise Comparativa das

Proposições de 1975 e 2004

Tese apresentada à Pós-graduação da Faculdade de Arquitetura e Urbanismo da Universidade de São Paulo, para obtenção do Título de Doutor.

Área de Concentração: Planejamento Urbano e Regional

\section{Aprovado em:}

\section{Banca examinadora:}

Prof. Dr.:

Instituição: Assinatura:

Prof. Dr.:

Instituição: Assinatura:

Prof. Dr.:

Instituição: Assinatura:

Prof. Dr.:

Instituição: Assinatura:

Prof. Dr.:

Instituição: Assinatura: 
Dedico esse trabalho ao meu Deus, à minha família, aos meus amigos e irmãos, sem o apoio dos quais nada disso seria possível, e sem o amor dos quais nada disso faria sentido.

"E ainda que tivesse o dom de profecia, e conhecesse todos os mistérios e toda a ciência, e ainda que tivesse toda a fé, de maneira tal que transportasse os montes, e não tivesse amor, nada seria".

1 Coríntios 13:2. 


\section{Agradecimentos}

Uma grande conquista nunca é um fato isolado. Ela é seguramente o resultado de muitos pequenos fatos anteriores que permitiram o alcance desse objetivo. Assim como quem conquista algo nunca está isolado também. Certamente tem por trás, ao lado, e por todos os lados, grandes conquistadores que juntamente com ele têm todo o mérito da conquista. Isso me lembra uma história da Bíblia, de uma batalha que foi vencida por um povo porque seu profeta tinha os braços sustentados por outros dois, que assim permaneceram até a vitória final:

"E acontecia que, quando Moisés levantava a sua mão, Israel prevalecia; mas quando ele abaixava a sua mão, Amaleque prevalecia. Porém as mãos de Moisés eram pesadas, por isso tomaram uma pedra, $e$ a puseram debaixo dele, para assentar-se sobre ela; e Arão e Hur sustentaram as suas mãos, um de um lado e o outro do outro; assim ficaram as suas mãos firmes até que o sol se pôs.(...) E Moisés edificou um altar, ao qual chamou: O SENHOR É MINHA BANDEIRA” Exxodo 17:11-15

Muitas pessoas sustentaram os meus braços durante essa batalha, que ora se faz em conquista. Muitos são os nomes de Arão e Hur nessa minha batalha chamada doutorado, desde o seu começo até o seu final: Michelly, Michela, Eduardo, Bernardo e Shimbo, do Mestrado na UFSCar, que me apoiaram na decisão de fazer o doutorado; Arlete, Ermínia, Rebeca, Ângela e Malu (orientadora especialíssima) e equipe da FAUUSP, que me deram oportunidades únicas de ingresso no curso e riquíssimos aprendizado e contribuições ao longo dele; Érika, Flávia, Alice, Lia, Ju, Paula, Tina, Luciana, Mariana L., Ana Paula, Ana Marta, Mari e Lícia (e Gui), amigas e irmãs do SENAC que me incentivaram e me apoiaram de diversas maneiras durante o curso; Claudia, Andréa, Avani, Nilva, Aline, Alessandra, Joana, Elaine e famílias, essas vizinhas, amigas e irmãs em Cristo que me sustentaram em oração, em cuidado, em apoio, em serviço nas horas mais difíceis da lida de ser mãe, dona-de-casa e doutoranda; assim também me sustentaram minha mãe, Ana e minha irmã, Fabíola, que abriram mão do seu tempo, do seu trabalho, da sua família, para estarem comigo nos momentos mais delicados da preparação do trabalho - só o Senhor poderá lhes compensar, minhas amadas; Mãe, a senhora é única, obrigado pelo seu amor incondicional; por isso também o meu agradecimento ao meu pai, Claudio, irmãos Claudinho, Adriano, Eli e Hermes, que abriram mão de suas queridas para que elas pudessem segurar os meus braços por um instante; por fim, meus dois tesouros mais preciosos, Jean, meu esposo amado, e Olivier, meu filhinho querido, que junto comigo viveram as maiores emoções dessa estória, e que me motivaram a manter os braços erguidos apesar das circunstâncias, e agora comigo levantam a bandeira da vitória.

Meus agradecimentos aos muitos outros e outras Arão e Hur que me sustentaram os braços em orações, em conversas, em palavras de apoio, em concessões, em informações, em orientações, em interesse, em serviço, em cuidado, em dedicação, em doação, em amor. Só tenho a agradecer a todos, e compartilhar essa conquista com cada um, que incluo como meus co-autores et alii e et aliae, porque indiretamente me ajudaram a escrever cada linha dessa tese.

E em especial, agradeço ao meu Senhor Jesus, que antes de todos se deu por mim para que eu tivesse a vida, e tem manifestado o seu amor e seu cuidado constante por mim e pela minha família, e de forma especial estendeu seu cuidado através dos muitos que enviou pra me ajudar, e operou de forma soberana transformando muitas adversidades em bênçãos ao longo desse processo. Obrigado, Senhor, eis aqui o meu altar, a ti dedico essa vitória. O SENHOR É MINHA BANDEIRA. 
Resumo

ADEODATO, M, T, P, C. A razão e os limites das políticas nacionais de desenvolvimento urbano: uma análise comparativa das propostas de 1975 e 2004. 2010. 301 p. Tese (Doutorado) - Faculdade de Arquitetura e Urbanismo, Universidade de São Paulo, São Paulo, 2010.

A presente tese busca compreender fundamentos e práticas da atuação do Estado sobre o urbano por meio das Políticas Nacionais de Desenvolvimento Urbano (PNDUs) elaboradas em dois momentos: uma no período militar, autoritário e centralizador, a PNDU de 1975, e outra na condição democrática, após a "Constituição Cidadã" de 1988, a PNDU de 2004, que assume a descentralização e tem o município como ente federativo. A pesquisa baseou-se em dados oficiais e pesquisas anteriores sobre essas políticas para investigar como foram concebidas e desenhadas pelo Estado, e se foram transpostas ou não em propostas e ações efetivas. Para isso analisou comparativamente fundamentos, razões e concepções de cada PNDU em seus contextos específicos, seus instrumentos institucionais, financeiros, legais e técnicos, bem como seus planos e programas implementados, de modo a constatar limitações que se impõem a essas Políticas. As constatações apontam para descontinuidades e continuidades, distinções e semelhanças entre as duas propostas. O autoritarismo, 0 centralismo e a ditadura de 1975 contrastam com a democratização e abertura à participação social e liberdades políticas em 2004. As proximidades se apresentam em propostas governamentais que pouco se efetivam na prática, políticas urbanas sem implementação, velhas ideologias que se revestem de novos discursos, mas se mantém sobre problemas que parecem crônicos: o clientelismo e o patrimonialismo Esse é o cenário sob o qual se pode observar as PNDUs, sem no entanto, esquecer-se que as cidades, bases sobre a qual atuam as Políticas de Desenvolvimento Urbano, são formas que refletem aspectos estruturais da sociedade e carregam o passivo de sua história e os arranjos sociais que se combinam ou se excluem, justificando e limitando a capacidade de impacto das PNDUs em seus contextos urbanos específicos.

Palavras-chave: Política Nacional de Desenvolvimento Urbano. Política Urbana. Planejamento Urbano e Regional. Política Nacional de Desenvolvimento Urbano de 1975. Política Nacional de Desenvolvimento Urbano de 2004. 
A bstract

ADEODATO, M, T, P, C. The reasons and the limits of the national policies for urban development: a comparative analysis of the proposals of 1975 and 2004 in Brazil. 2010. 301 p. Doctoral Thesis- Faculdade de Arquitetura e Urbanismo, Universidade de São Paulo, São Paulo, 2010.

This research approaches urban and regional planning in Brazil, and intends to discuss urban development policies at a federal level. The case studies employed in this work are the only two proposals of national urban policies developed in Brazil, during the years of 1975 and 2004. The research goals were defined in terms of comparatively analyzing the two referred proposals as directions to public decisions and actions towards urban and regional development. The research conclusions evidence that the distinct social, economical and political conditions of government, such as centralization/authoritarism, or decentralization/democratization, or even economic contexts can influence the contents and proposals of the urban public policies designed at federal level. There is also evidence that the manner in which the government is organized - in this instance federalism - the intergovernmental relations, the decision making process, and the institutional, technical, regulatory instruments that support each Policy may limit the implementation of the plans, programs and actions of such policies, designed to improve urban and regional development.

Key words: National Policies of Urban Development. Urban Policies. Urban and Regional Planning. National Policies of Urban Development of 1975 in Brazil. National Policies of Urban Development of 2004 in Brazil. 
Résumé

ADEODATO, M, T, P, C. Les raisons et les limites de la politique nationale de développement urbain: une analyse comparative des propositions de 1975 et 2004 au Brésil. 2010. 301 p. Thèse du Doctorat - Faculdade de Arquitetura e Urbanismo, Universidade de São Paulo, São Paulo, 2010.

Cette recherche aborde la planification urbaine et régionale au Brésil, plus précisément, elle se penche sur les études qui ont été menées sur les politiques de développement urbain à l'échelon fédéral. Les cas d'études bien définis sont les deux seules propositions de la politique nationale en milieu urbain développées au Brésil au cours des années 1975 et 2004. Les objectifs de recherche visent à analyser comparativement les deux propositions mentionnées, qui représentent les décisions du gouvernement fédéral concernant le développement urbain et régional. Les conclusions du travail démontrent que les différents contextes sociaux, économiques et politiques, comme la centralisation / autoritarisme, ou la décentralisation / démocratisation, ou encore les contextes économiques, peuvent influencer les contenus et propositions c'est à dire les «raisons d'être» des politiques urbaines fédérales. Les résultats démontrent également que l'organisation du gouvernement, tel que le fédéralisme, les relations intergouvernementales, le processus de prise de décision et les instruments institutionnels, techniques et réglementaires peuvent limiter la mise en œuvre des plans, programmes et actions des politiques nationales, ayant en vue l'amélioration du développement urbain et régional.

Mots clés: La Politique Nationale de Développement Urbain. La Politique Urbaine. Planification Urbaine et Régionale. La Politique Nationale de Développement Urbain de 1975 au Brésil. La Politique Nationale de Développement Urbain de 2004 au Brésil. 


\section{LISTA DE TABELAS, GRÁFICOS, MAPAS E FIGURAS}

\section{TABELAS}

Tabela 1 - Balanço das Resoluções Emitidas pelo Conselho das Cidades de 2004-2005

Tabela 2 - Total de cidades por região, classificadas em número de habitantes (PNDU de 1975)

Tabela 3 - Receita total arrecadada por esfera de governo no contexto da PNDU de 1975 207

Tabela 4 - Aplicações previstas para desenvolvimento urbano (1975-1979) 209

Tabela 5 - Arrecadação tributária federal de 2004-2009 215

Tabela 6 - Recursos financeiros para habitação (em R $\$ 1$ milhões) - Governo Federal 2003/2004. 216

Tabela 7 - Domicílios particulares ocupados em 1970 240

Tabela 8 - Evolução da população coberta pelo Planasa em termos de abastecimento de água, segundo regiões (1970-1991) - (em milhares)

Tabela 9 - Evolução da população coberta pelo Planasa em termos de esgotamento sanitário, segundo regiões (1970-1991) - (em milhares).

Tabela 10 - Aplicações PNCCPM - 1976 a 1982 - por regiões (previsão) . 250

Tabela 11 - Domicílios particulares ocupados em 2004 263

Tabela 12 - Distribuição dos prestadores de serviço participantes do SNIS em 2008, segundo características de atendimento. .268

Tabela 13 - Níveis de atendimento com água e esgotos dos prestadores de serviços participantes do SNIS em 2008, por região demográfica. .269

\section{GRÁFICOS}

Gráfico 1 - Balanço das Resoluções Emitidas pelo Conselho das Cidades de 20042005

Gráfico 2 - Composição do Conselho das Cidades: proporcionalidade de segmentos 96

Gráfico 3 - Crescimento anual da renda nas regiões 142

Gráfico 4 - Evolução da população total - 1950-2000 144

Gráfico 5 - Evolução da densidade demográfica regional - 1950-2000 145

Gráfico 6 - Evolução da população urbana regional - 1950-2000 147

Gráfico 7 - Distribuição nacional de cidades, por, classificadas por total de habitantes (PNDU de 1975) 
Gráfico 8 - Perfil de arrecadação das três esferas de governo de 1968 a 1972 _.......207

Gráfico 9- Aplicações previstas para o desenvolvimento urbano (1975-1979)...........210

Gráfico 10 - Evolução da participação dos níveis de governo no total da receita

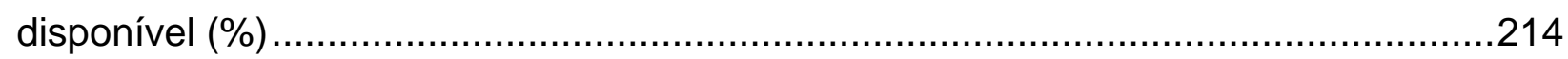

Gráfico 11 - Investimentos do PLANASA por região, no período de 1968-1974 .......244

Gráfico 12 - Abastecimento de Água - População Atendida pelo Planasa ................245

Gráfico 13 - Evolução da População Coberta pelo PLANASA em termos de

esgotamento sanitário, segundo regiões, de 1970 a 1991)

Gráfico 15 - Relação entre a quantidade de municípios de médio porte e recursos

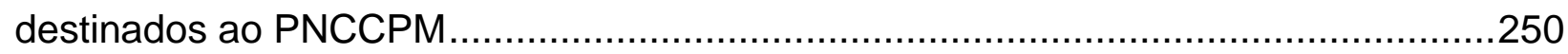

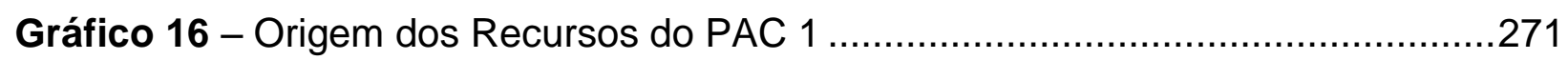

Gráfico 17 - Destino dos investimentos do PAC 1 - POR EIXO.............................272

Gráfico 18 - Volume de investimentos previstos segundo as áreas prioritárias do PAC

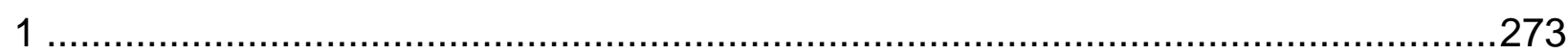

\section{MAPAS}

Mapa 1 - Mapa do desenvolvimento urbano na PNDU de 1975 ...............................72

Mapa 2 - Tipos de regiões segundo interações espaciais - PNDU de 1975 ..............138

Mapa 3 - Mapas de População Total em 2000, Evolução da População Total de 1991 a 2000 e Densidade demográfica, em 2000 .............................................................146

Mapa 4 - Mapa de População Urbana em 200, Evolução da População Urbana de

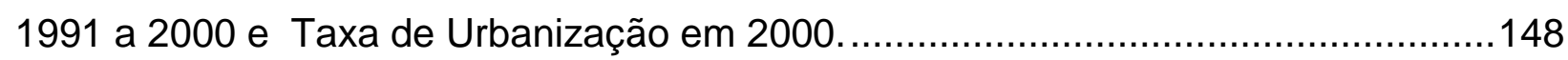

Mapa 5 - Mapa da exclusão/inclusão de São Paulo................................................149

Mapa 6 - Distribuição de população urbana em situação 1, 2 e 3 - 2000 ……............160

\section{FIGURAS}

Figura 1 - Esquema de elaboração das proposições da PNDU de 2004. .92

Figura 2 - Sistematização de distribuição de recursos entre os entes federados após a Constituição de 1988 (sistematização da autora).

Figura 3 - Conjunto habitacional do Banco Nacional da Habitação (BNH) em Ji -

Paraná (RO) .242 


\section{LISTA DE SIGLAS}

BID - Banco Interamericano de Desenvolvimento

BIRD - Banco Internacional para Reconstrução e Desenvolvimento

BNDES - Banco Nacional de Desenvolvimento Econômico e Social

BNH - Banco Nacional de Habitação

CEF - Caixa Econômica Federal

CEPAL - Comissão Econômica para a América Latina e o Caribe

CEPEU - Centro de Pesquisa e Estudos Urbanísticos da Faculdade de Arquitetura e Urbanismo da USP

CF - Constituição Federal

CNDU - Conselho Nacional de Desenvolvimento Urbano

CNPU - Comissão Nacional de Regiões Metropolitanas e Políticas Públicas

COFINS - Contribuição para o Financiamento da Seguridade Social

COHAB - Companhia de Habitação

DASP - Departamento de Administração Pública

DNOS - Departamento Nacional de Obras de Saneamento

EC - Estatuto da Cidade

ESG - Escola Superior de Guerra

FDPI - Fundo de Desenvolvimento de Programas Integrados

FDU - Fundo de Desenvolvimento Urbano

FGTS - Fundo de Garantia por Tempo de Serviço

FGV - Fundação Getúlio Vargas

FINANSA - Programa de Financiamento para o Saneamento

FINEP - Financiadora de Estudos e Pesquisas

FIPLAN - Programa de Financiamento para o Planejamento Urbano

FUNDERB - Fundos de Desenvolvimento Urbano

FUNDHAP - Fundo de Habitação popular

IBGE - Instituto Brasileiro de Geografia e Estatística

ICMS - Imposto sobre Circulação de Mercadorias e Prestação de Serviços

IOF - Imposto sobre Operações financeiras

IPEA - Instituto de Pesquisa Econômica Aplicada

IPI - Imposto sobre Produtos Industrializados

IPLAN - Instituto do Planejamento

IR/CSLL ativos - Ativos Fiscais Diferidos 
ISSQN - Imposto Sobre Serviços de Qualquer Natureza

ITBI - Imposto Sobre a Transmissão Intervivos

LRF - Lei de Responsabilidade Fiscal

MCMV - Programa Minha Casa Minha Vida

MeBAG - Programa de Metas e Bases do Governo

MINTER - Ministério do Interior

MRU - Movimento Pela Reforma Urbana

OEA - Organização os Estados Americanos

PAC - Programa de Aceleração do Crescimento

PAEG - Plano de Ação Econômica do Governo

PAR - Programa de Arrendamento Residencial

PD - Plano Diretor

PDDU - Plano Diretor de Desenvolvimento Urbano

PDL - Plano Diretor Local

PDLI - Planos de Desenvolvimento Local Integrado

PECON - Programas Estaduais de Controle de Poluição

PIN - Programa de Integração Nacional

PITURB - Programa de Integração de Transportes Urbanos

PLANASA - Plano Nacional de Saneamento

PLANHAB - Plano Nacional de Habitação (2004)

PLANHAP - Plano Nacional de Habitação Popular

PMCMV - Programa Minha Casa Minha Vida

PNCC - Programa Nacional de Capacitação de Cidades

PNCCP - Programa de Apoio às Capitais e Cidades de Porte Médio

PNCDA - Programa Nacional de Combate ao Desperdício de Água

PND - Plano Nacional de Desenvolvimento

PNDU - Política Nacional de Desenvolvimento Urbano

PNH - Política Nacional de Habitação

PPA - Plano Plurianual

PRODEPO - Projeto de Apoio ao Desenvolvimento dos Pólos Econômicos

PRODOESTE - Programa de Desenvolvimento do Centro-Oeste

PRORRURAL - Programa Especial de Crédito Rural

PROTERRA - Programa de Redistribuição de Terras do Norte e Nordeste

PROVALE - Programa Especial para o Vale do São Francisco

RIG - Relação Intergovernamental

RM - Região Metropolitana 
SAGMACS - Sociedade de Análise Gráfica e Mecanográfica Aplicada aos Complexos Sociais

SBPE - Sistema Brasileiro de Poupança e Empréstimo

SEMA - Secretaria Especial de Meio Ambiente

SERFHAU - Serviço Federal de Habitação e Urbanismo

SIMAHAB - Sistema de Informação, Avaliação e Monitoramento da Habitação

SNH - Sistema Nacional de Habitação

SNIS - Sistema Nacional de Informações sobre Saneamento

SNPLI - Sistema Nacional de Planejamento Local Integrado

SUDAM - Superintendência de Desenvolvimento da Amazônia

SUDENE - Superintendência de Desenvolvimento do Nordeste

SUS - Sistema Único de Saúde

USP - Universidade de São Paulo 


\section{SumÁRIO}

INTRODUÇÃO

CAPÍTULO 1.

1. A ÁREA DE CONHECIMENTO

1.1. A urbanização e os processos socioeconômicos de transformação das cidades 27

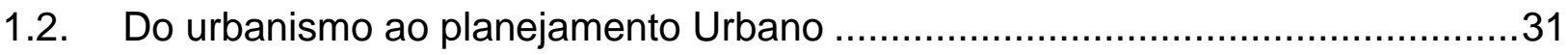

1.3. O planejamento urbano e regional: a crítica e a prática.....................................33

1.4. A política urbana: conceitos, direitos e instrumentos …...................................43

1.5. Federalismo: o sistema e o pacto .................................................................

CAPÍTULO 2

2. POLÍTICAS DE DESENVOLVIMENTO URBANO NO BRASIL ........ 54

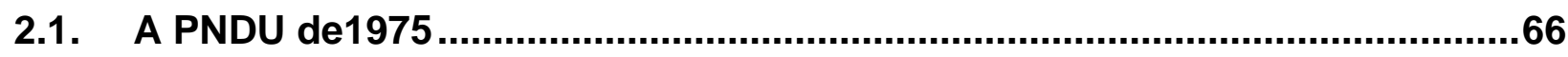

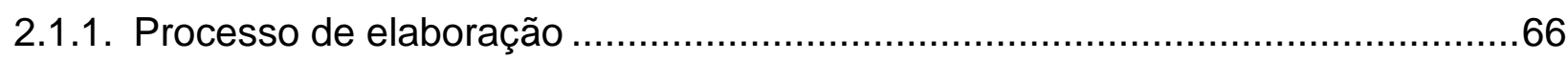



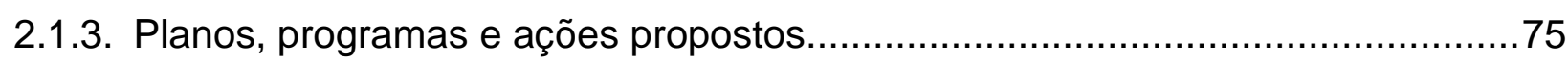

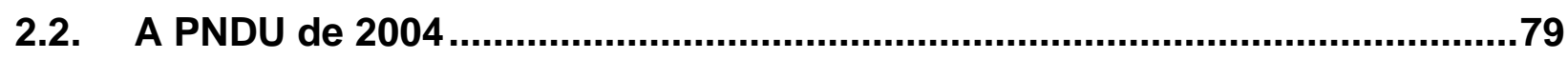

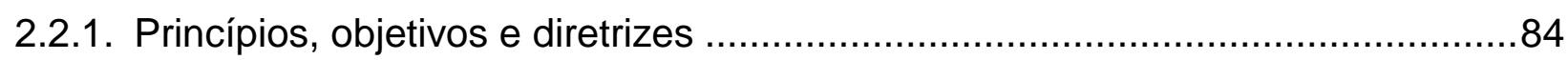

2.2.2. A sistemática de construção da nova PNDU: a busca da pactuação federativa

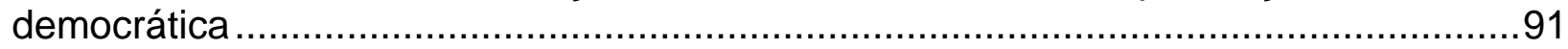

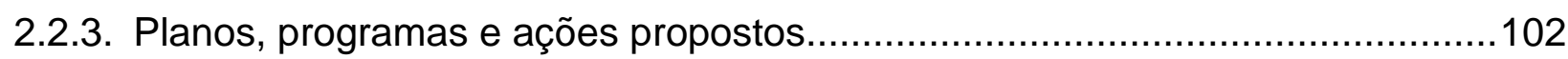

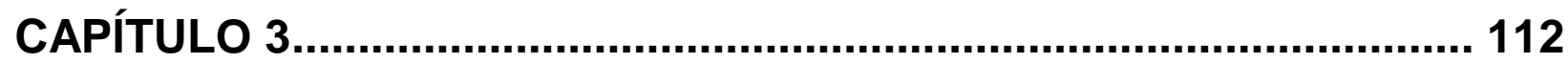

3. EIXOS COMPARATIVOS - CONTEXTOS, PRESSUPOSTOS E PRINCÍPIOS .................................................................................. 112

3.1. ASPECTOS POLÍTICOS E SÓCIO-ECONÔMICOS .......................................112

3.1.1. Contextos e debates: economias periféricas e golpes militares na América Latina

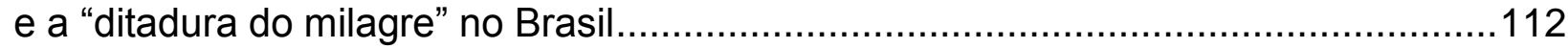

3.1.2. A PNDU de 1975: industrialização, autoritarismo e crise econômica ...............117

3.1.3. A PNDU de 2004 e um "novo" contexto: crises econômica e urbana e ausência do estado na virada neoliberal......................................................................121

3.1.4. Considerações: a influência dos contextos nas PNDUS.................................129 
3.2. QUESTÃO TERRITORIAL, REGIONAL, METROPOLITANA

3.2.1. Contextos e debates: planejamento regional, teoria dos pólos de desenvolvimento e a metropolização no Brasil...... 133

3.2.2. A PNDU de 1975: foco nas regiões e metrópoles ...........................................150

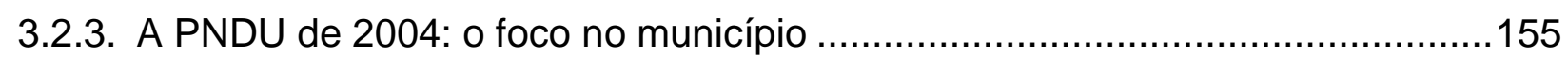

3.2.4. Considerações: planejamento territorial, desequilíbrio regional e "vazio" metropolitano. 163

3.3. A QUESTÃO FEDERATIVA................................................................170

3.3.1. Contextos e debates: federalismo e descentralização ...................................170

3.3.2. PNDU de 1975: o pacto federativo e o discurso cooperativo.............................173

3.3.3. PNDU de 2004: o pacto federativo nas discussões da nova PNDU .................175

3.3.4. Considerações sobre a competência comum e a difícil cooperação intergovernamental.

CAPÍTULO 4..................................................................................... 188

4. EIXOS COMPARATIVOS - INSTRUMENTOS .............................. 188

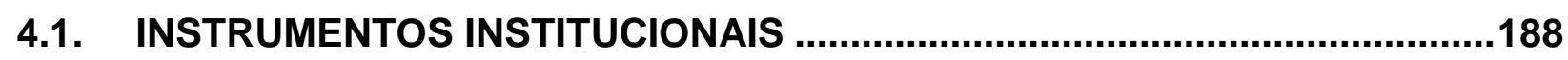

4.1.1. Relações governamentais e competências dos governos ................................189

4.1.2. A estrutura institucional da PNDU de 1975: a subordinação federativa ............192

4.1.3. A estrutura institucional da PNDU de 2004: a tentativa de pactuação federativa

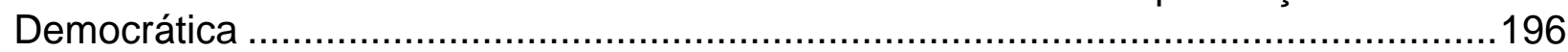

4.1.4. Considerações sobre as relações intergovernamentais no Brasil ...................202

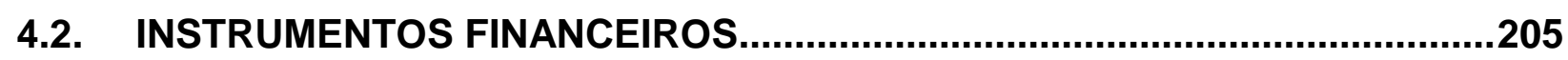

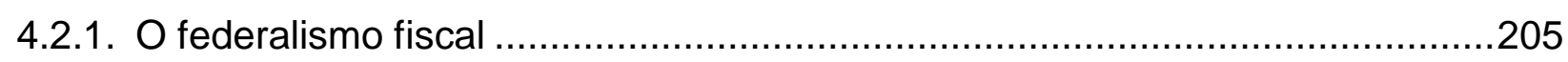

4.2.2. A PNDU de 1975: financiamento e ajustes fiscais ..........................................206

4.2.3. A PNDU de 2004: novas fontes de recursos e rearranjos fiscais ....................211

4.2.4. Considerações sobre o federalismo fiscal e a competição intergovernamental 218

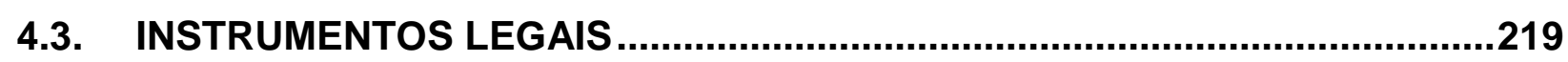

4.3.1. Institutos jurídico-urbanísticos e sua trajetória histórica no Brasil....................219

4.3.2. Legislação à época da PNDU de 1975 .......................................................220

4.3.3. Legislação à época da PNDU de 2004 .........................................................22

4.3.4. Considerações sobre a evolução dos institutos jurídico-urbanísticos e o desafio

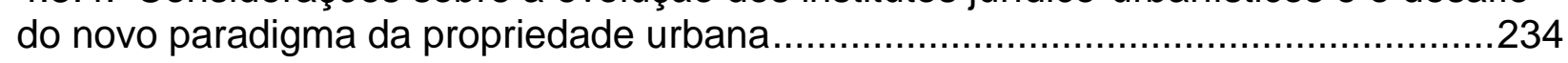

4.4. INSTRUMENTOS TÉCNICOS.............................................................235

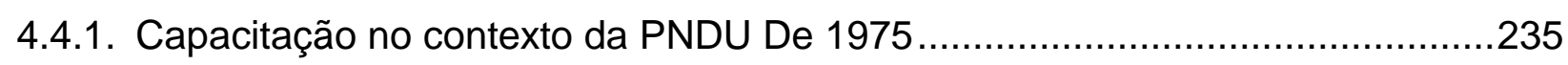

4.4.2. Capacitação no contexto Da PNDU De 2004 .............................................237 
CAPÍTULO 5.

5. EIXOS COMPARATIVOS: PLANOS, PROGRAMAS E AÇÕES IMPLEMENTADOS. 239

5.1. PLANOS, PROGRAMAS E AÇÕES DA PNDU DE 1975. .239

5.1.1. PLANHAP (Plano Nacional de Habitação Popular) .239

5.1.2. PLANASA (Plano Nacional de Saneamento) 242

5.1.3. PNCCPM (Programa Nacional de Capitais de Cidades de Porte Médio) .247

5.1.4. Plano de Complementação Urbana - Projetos CURA. 252

5.1.5. Os planos de desenvolvimento local integrado .255

5.2. PLANOS, PROGRAMAS E AÇÕES DA PNDU DE 2004 .258

5.2.1. Os Planos Diretores Participativos .258

5.2.2. Plano Nacional de Habitação 262

5.2.3. Plano de Saneamento Básico (Lei $11.445 / 2007$ Nacional do Saneamento Básico). 266

5.2.4. O Programa de Aceleração do Crescimento - PAC (1) .270

5.3. CONSIDERAÇÕES SOBRE OS PLANOS, PROGRAMAS E AÇÕES .276

CAPÍTULO 6. 278

6. CONSIDERAÇÕES FINAIS 278 
I

A presente tese busca compreender os fundamentos e práticas das Políticas Nacionais de Desenvolvimento Urbano no contexto brasileiro, por meio de duas propostas elaboradas em dois momentos: uma no período militar, autoritário e centralizador e outra na condição democrática, após a constituição de 1988, a "Constituição Cidadã", que assume a descentralização, passando o município a ser ente federativo.

As duas experiências de elaboração de políticas nacionais de desenvolvimento urbano (PNDU) a serem consideradas nessa análise são a Política Nacional de Desenvolvimento Urbano desenvolvida em 1975, Capítulo 5 do Programa de Ação do Governo na Área do Desenvolvimento Urbano, dentro do II PND - cuja fonte de referência é o documento publicado pelo Ministério do Interior $^{1}$ nesse mesmo ano, e o texto da nova PNDU, processo conduzido pelo Ministério das Cidades, a partir de 2004, para o que se utilizou como fonte de referência as publicações "Cadernos MCidades" 2 , especialmente o № 1, que trata da Política Nacional de Desenvolvimento Urbano.

Para que se possa compreender a dimensão desse objetivo, algumas considerações preliminares são necessárias.

\section{II}

A segregação sócio-espacial urbana, bem como a exclusão, a violência, a falta de moradia, e de emprego atuais são produtos de uma somatória de relações sociais e de opções políticas que atravessam a história do país.

As heranças do passado e os contingenciamentos do presente fazem da cidade um espaço intrincado no jogo de poder que se torna mais complexo à medida dos interesses dos diversos atores que disputam o território, como o capital privado, os

\footnotetext{
${ }^{1}$ MINISTÉRIO DO INTERIOR. Secretaria Geral. II Plano Nacional de Desenvolvimento; programa de ação do governo na área do desenvolvimento, 1975-79. Brasília, 1975.

${ }^{2}$ MINISTÉRIO DAS CIDADES. Cadernos MCidades: Política Nacional de Desenvolvimento Urbano.

Brasília, 2004.
} 
mercados interno e externo, as demandas sociais crescentes pela democratização do acesso ao espaço urbanizado, e o Estado, que oscila em posições ambíguas de defesa do interesse público e privado ao mesmo tempo.

Nesse processo, o Estado brasileiro acaba assumindo papéis diversos, ora como o intermediador dos conflitos sociais, ora como garantidor dos interesses privados, ora como regulador do mercado, mas sempre marcado por uma trajetória histórica de patrimonialismo e mediador das pressões sociais por mudanças no processo de apropriação privada do espaço urbano.

A herança brasileira de uma ação protecionista ao mercado pelo Estado pode ser constatada desde os tempos coloniais, onde a organização dos núcleos urbanos voltava-se para atender aos interesses agro-exportadores da Metrópole. No período da industrialização, a concentração de população e recursos, bem como a localização privilegiada de algumas regiões, revelava e reforçava a direção dos investimentos "estatais", o que acabou por fomentar um processo de agudização do desequilíbrio econômico e de concentração populacional entre as regiões.

Atualmente, a necessária redução das desigualdades no sistema urbano e regional no território brasileiro, o vazio institucional das metrópoles e a sobrecarga municipal de responsabilidades sobre o desenvolvimento urbano, demandam uma revisão da atuação do Estado, de modo que se produzam políticas e ações profícuas para o crescimento das regiões mais atrasadas, que se reconheça a metrópole como uma instância de governo necessária ao desenvolvimento urbano e regional, e que se forneçam subsídios e condições de governabilidade e autonomia municipal para as políticas de desenvolvimento urbano a serem criadas e implementadas nas cidades.

A pesquisa tem suas bases lançadas, então, justamente a partir dessa problemática dos municípios, com a conclusão da dissertação de mestrado sobre políticas públicas municipais ${ }^{3}$, em que se verificou a grande limitação dos municípios

\footnotetext{
${ }^{3}$ ADEODATO, M.T.P.C. Análise das Estratégias para o Projeto de Incorporação de Princípios e Indicadores da Sustentabilidade em Políticas Públicas no Município de Jaboticabal-SP. 2005. $276 f$. Dissertação (Mestrado em Engenharia Urbana) - Departamento de Engenharia Civil, Universidade Federal de São Carlos, São Carlos. Essa dissertação foi desenvolvida no âmbito do projeto temático de políticas públicas financiado pela FAPESP "Incorporação e Princípios e Indicadores de Sustentabilidade em Políticas Urbanas de Pequenos e Médios Municípios", implementada em parceria com a Prefeitura municipal de Jaboticabal, ficando conhecido como "Projeto Jaboticabal Sustentável", do qual participei como pesquisadora e coordenadora executiva nos anos de 2003, 2004 e 2005.
} 
na execução de políticas urbanas, mesmo diante da autonomia, recursos e atribuições específicas sobre o desenvolvimento urbano que lhe foram passadas na Constituição de 1988.

$\mathrm{Na}$ medida em que se observa em muitas circunstâncias uma grande fragilidade do poder público municipal no controle sobre o uso e ocupação do solo urbano, mediante limitações que excedem suas competências, os planos diretores e demais instrumentos de política urbana ainda se mostram insuficientes para ir além do uso funcionalista da cidade e promover o direito ao seu acesso e usufruto pela parcela dela excluída.

Decorrentes da mudança constitucional de 1988 são redefinidas as competências dos três entes federados no que diz respeito ao desenvolvimento urbano. A partir de então o governo federal deve dar as diretrizes para as políticas urbanas nacionais, e passa a ser de responsabilidade prioritária do município a execução dos planos, programas e ações propostos a partir das definições da política nacional de desenvolvimento urbano, que podem ser realizados em parceria com os demais governos. São novos contornos para as relações intergovernamentais e nova tentativa de fortalecer o fragilizado pacto federativo nacional.

A cooperação federativa sofreu um duro golpe com a centralização imposta pelo governo militar, contexto em que foi gerada a PNDU de 1975. Por outro lado, ela é elemento central para a realização da PNDU de 2004. No entanto, nas duas situações, evidencia problemas e limitações, seguindo como desafio.

As questões de pesquisa giram em torno de como foram concebidas e desenhadas as Políticas de Desenvolvimento Urbano e como seus fundamentos, razões e concepções do Estado em cada momento, foram transpostos ou não em propostas e em ações efetivas. Outro ponto central da investigação é compreender quais as limitações que se impõem a essa políticas, de caráter nacional, definidas em nível federal, mas que têm na cidade, no município, nas metrópoles e na região, seu "espaço" físico de implementação das ações.

A discussão se coloca também quanto às condições do Estado de pôr em ação seu projeto político e social que se manifesta nas políticas nacionais de desenvolvimento urbano. 


\section{III}

Num resumo do escopo conceitual da tese, tem-se que o campo de pesquisa é o do planejamento urbano e regional. A urbanização é o fenômeno que justifica a criação das PNDUs, como processo de transformação do espaço da (e pela) sociedade. A política urbana, por sua vez, é o tema central da pesquisa, a partir das propostas produzidas pelo Estado. Tendo em vista a questão da estruturação do Estado, um dos pontos da tese é a importância do federalismo nesse processo, as instituições e os atores.

A urbanização foi o processo que modificou significativamente a ocupação do solo urbano e foi a partir das conseqüências decorrentes desse fenômeno que se justificou a ação do Estado para mitigação dos problemas que passam a se acumular nas cidades.

O planejamento urbano e regional, apreendido em suas diversas abordagens, é o campo principal em que está inserida a pesquisa. É também com instrumental desse campo que se analisam os processos, contextos, produtos e impactos das PNDUS.

A política urbana, tema central da pesquisa, tem sua relação com o planejamento urbano, com o poder, com a própria política como contexto, com a economia, com a sociedade e com o Estado. Como política pública é fruto de um processo decisório que envolve interesses diversos, reflete prioridades de grupos políticos, que privilegia e exclui, e que se abre ou se fecha à participação, conforme contextos históricos. Como dependente de um processo decisório, sofre ainda os constrangimentos dos condicionantes políticos e institucionais, das "regras do jogo"” que determinam a aprovação ou não de projetos em votação.

O sistema federalista, adotado no Brasil desde a república, surge eivado de conflitos e disputas entre as oligarquias regionais. Por isso o federalismo se torna relevante no estudo de políticas públicas, pelo que aporta negociações ou ajustes entre os membros da federação na implementação de determinada política em seus diversos níveis e contextos.

Delimitando-se então a pesquisa, ficaram definidos: (i) a política urbana federal como o objeto de pesquisa; (ii) o processo de formulação, caminhos e meios para implementação de uma política urbana federal como os eventos as serem estudados (iii) as políticas nacionais de desenvolvimento de 1975 e 2004, os estudos de caso; (iv) 
e os contextos, os instrumentos e os programas, planos e ações das PNDUs, bem como justificativas e os fatores limitantes dos processos, como as categorias de comparação a serem analisadas.

Em síntese, o objetivo do trabalho foi desenvolver uma pesquisa mais extensa sobre as duas PNDUs, por meio de uma análise comparativa das duas experiências, seus contextos, suas diretrizes propostas, suas proposições enquanto planos, programas e ações, e averiguando o que foi possível transpor das diretrizes para ações por meio das políticas, programas e ações locais de desenvolvimento urbano implementados em seus respectivos contextos.

A pesquisa busca uma visão de conjunto das políticas, tanto quanto produzir análises comparativas que permitam identificar os aspectos centrais de cada uma delas, assim como semelhanças e divergências. Para tanto, considera encontrar proposições e contextos de concepção e elaboração, como também os instrumentos, planos, programas, e ações que desencadearam.

As bases de referência da pesquisa são documentos, programas, relatos e dados oficiais, ou seja, trabalha-se apenas com dados secundários, seja por relatórios ou por informações estatísticas já existentes, sempre informações de domínio público. Em complementação, recorre-se à produção acadêmica que anteriormente se ocupou dessas políticas.

A partir das questões formuladas e do material recolhido e selecionado fez-se necessário a especificação das categorias de análise, assumidas como eixos comparativos das PNDUs. A análise comparativa se desenvolve, então, segundo os seguintes eixos: contextos, pressupostos e princípios (envolvendo aspectos políticos e sócio-econômicos, a questão territorial, regional, metropolitana e a questão federativa); instrumentos (institucionais, financeiros, legais e técnicos); planos, programas, e ações.

Os resultados da pesquisa estão apresentados ao longo de seis capítulos, assim estruturados: o primeiro constituiu-se a partir dos conceitos e debates delimitadores do campo da pesquisa; o segundo, da apresentação e caracterização das PNDUs; o terceiro, quarto e quinto capítulos, de análise comparativa das PNDUs, segundo os oito eixos de análise; e o sexto capítulo apresentando algumas 
considerações finais e conclusões. A descrição mais detalhada de seus conteúdos é o que segue.

O Capítulo 1 - A ÁREA DE CONHECIMENTO investigou os aspectos conceituais que a política nacional de desenvolvimento urbano pode envolver, tratando de explorar primeiramente nesse momento a área de conhecimento que envolve a tese. A princípio apresentou-se o debate acerca do planejamento urbano e regional, limitando sua abordagem como o campo disciplinar da política urbana, tangenciando apenas um longo debate existente sobre planejamento e seus vários usos dentro do urbanismo e da política. O objetivo foi ter um panorama dos principais conceitos relacionados ao planejamento e políticas urbanas e regionais, particularizado no Brasil.

\section{No Capítulo 2 - POLÍTICAS DE DESENVOLVIMENTO URBANO NO BRASIL} delineou-se a trajetória histórica das políticas urbanas nacionais e apresentou-se descritivamente os conteúdos das PNDUs de 1975 e 2004. A primeira parte do Capítulo apresentou sucintamente um breve panorama do desenvolvimento urbano nacional, e os planos e políticas que antecederam a criação das PNDUs. Em seguida, tratou-se de sistematizar informações sobre as PNDUs, referenciando-se principalmente nas publicações oficiais de 1975 e 2004, que apresentam os princípios básicos e as diretrizes das políticas nacionais de desenvolvimento urbano propostas em cada um desses momentos, explorando os conteúdos dos documentos oficiais relativos a cada PNDU.

Os Capítulo 3, 4 e 5 abordaram os eixos comparativos das PNDUs, a partir da análise mais aprofundada de seus conteúdos.

No Capitulo 3 - EIXOS COMPARATIVOS: Contextos, pressupostos e princípios, tratou-se de se verificar os contextos político, econômico, social e territorial que se apresentavam na elaboração de cada uma das PNDUs, uma vez que esses contextos muitas vezes foram/são determinantes, condicionantes ou esclarecedores das decisões tomadas pelos policy makers. Ou seja, procurou-se investigar o que justificou ou legitimou a iniciativa do governo federal para a elaboração dessas políticas, quais os interesses predominantes, e as visões, estratégias ou discursos / ideologias que acabaram por delinear as diretrizes nacionais para o desenvolvimento urbano. O capítulo observou ainda o foco da escala espacial de cada PNDU e o tratamento de questões essenciais nesse âmbito, como a territorial, a regional, a 
metropolitana, a intra-urbana, etc. Destaca-se o tratamento dado às cidades e regiões em cada uma das políticas nacionais.

No segundo capítulo comparativo, o Capítulo 4 - EIXOS COMPARATIVOS: Instrumentos foram explorados os instrumentos institucionais, financeiros, legais e técnicos, e verificou-se: (i) o quadro institucional, ou seja, o aparato governamental e orientações gerais para as políticas urbanas; (ii) os recursos e procedimentos empregados; (iii) a legislação e regulamentação urbanas relacionadas às PNDUs; (iv) as propostas de capacitação dos agentes públicos; enfim, os instrumentos e meios disponíveis em cada contexto em que as PNDUs foram construídas.

$\mathrm{Na}$ última parte comparativa da pesquisa, o Capítulo 5 - EIXOS COMPARATIVOS: Planos, programas e ações foram estudados os desdobramentos das PNDUs em termos de planos, programas e ações.

No Capítulo 6 - CONSIDERAÇÕES FINAIS da pesquisa articulam-se as principais constatações sobre as PNDUs encontradas ao longo da tese. O Capítulo levanta ainda questões relativas ao desenvolvimento das PNDUs, como as dificuldades de integração de diferentes visões e contradições encontradas na PNDU de 1975, ou a dificuldade de se implementar os instrumentos do Estatuto da Cidade no período mais recente, por exemplo, são elementos que podem explicitar melhor as "as razões e os limites" dessas políticas. 
Capítulo 1 


\section{$\mathbf{C}_{\text {APitulo1 }}$}

\section{A ÁREA DE CONHECIMENTO}

Os temas abordados neste item são uma reflexão inicial sobre o campo de pesquisa, ou seja, os processos, fenômenos e categorias relacionados ao objetos, no caso as PNDUs, com o objetivo de delimitar a área de conhecimento e o campo de abordagem a serem considerados, a fim de se introduzirem os debates que se desenvolvem ao longo da tese.

\subsection{A Urbanização e os processos socioeconômicos de transformação das cidades}

Três fenômenos são essenciais para se compreender as grandes mudanças no espaço nos últimos séculos e décadas recentes: a revolução industrial, o avanço do capital e a globalização. O primeiro é o fenômeno de partida que abre precedentes para o segundo, e o terceiro, impacta e eleva os patamares de desenvolvimento dos demais, em termos de tecnologias, articulações e novos modos de se entender o espaço e o território.

A industrialização é o fenômeno histórico que marca de vez a transformação das relações de produção e consumo, de trabalho, de empregador e empregados, das relações sociais familiares, culturais e de lazer, do homem com a natureza, do homem com seu meio, mudanças que impactaram de forma irreversível o tratamento e a ocupação do espaço urbano.

As conseqüências das avassaladoras transformações produzidas se fazem sentir justamente no lócus principal de atuação da indústria e produto direto da sua expansão, as cidades como as conhecemos hoje, centros de produção e consumo, palco de conflitos, cenários de exclusão social e degradação ambiental.

No Brasil, sobre sua rede original de cidades vinculadas ao modelo agroexportador, a industrialização se instalou marcando uma transformação nos modos de produção e organização social e espacial urbanos. A fase industrial que chega ao 
Brasil revela-se como um reflexo do processo ocorrido nos países centrais, séculos antes. A entrada do capital privado estabeleceu novas relações sociais e novos antagonismos que serão reestruturados a partir do processo de urbanização.

No período de centralização política do regime militar, na segunda metade do século passado, o processo de urbanização tomava proporções crescentes, bem como os problemas dela decorrentes. O texto de introdução da PNDU de 1975 assim relatava a situação urbana no período: "o expressivo índice de crescimento econômico e social que se verifica no País nos últimos anos vem acarretando sensíveis modificações no sistema urbano brasileiro, especificamente nas grandes metrópoles. A urbanização, na verdade, é uma das características marcantes do processo de transformação social por que passa o Brasil" (MINISTÉRIO DO INTERIOR, 1975).

O referido documento aponta a industrialização e as chamadas "atividades produtivas" como os principais responsáveis por essas modificações no sistema urbano e nas características intra-urbanas: "As atividades produtivas vêm se desenvolvendo e crescendo rapidamente nas maiores cidades, num processo acelerado de urbanização e industrialização, dentro do qual se observam distorções, seja do ponto de vista da distribuição espacial, dominantemente litorânea, seja quanto às funções desempenhadas pelas diferentes cidades, ou ainda, quanto ao nível de qualidade dos equipamentos urbanos oferecidos à população" (Idem, p. 7).

Do ponto de vista socioeconômico, as condições oferecidas à mão-de-obra industrial, em termos de salário, moradia, transportes, equipamentos urbanos, eram extremamente precárias, como precária foi a "parte" da cidade produzida a partir dessa massa de excluídos dos ganhos (em termos quantitativos ou qualitativos) dos processos de acumulação. É o que explica Maricato:

"Os baixos salários pagos aos trabalhadores industriais brasileiros é que explicam porque um trabalhador de uma indústria que era avançada até a década de 1980 morava em favelas. Tratava-se e trata-se ainda da 'industrialização com baixos salários' que gerou uma 'urbanização com baixos salários': excluídos do mercado os trabalhadores constroem suas moradias e até mesmo seus bairros. A derrocada do Welfare State, ainda que em versão periférica, e o aumento do desemprego apenas radicalizaram essa situação nas décadas de 1980 e 1999 (MARICATO, 2010, p. 13). 
A despeito dos problemas intra-urbanos (sócio-espaciais) em agravamento no período militar e em anos subseqüentes, o foco das atenções do governo estava no desequilíbrio dos sistemas urbano e regional provocado pela diferenciação de tratamento de cada cidade, de acordo com sua função dentro do sistema produtivo nacional, tendo como preocupação de fundo a questão econômica nacional. Outro problema apontado é o das altas taxas de expansão urbana, mas concentrado em um número relativamente pequeno de cidades, principalmente nos grande centro metropolitanos.

Constatou-se que em 20 anos a população urbana do Brasil havia passado de 36\% do total da população em 1950 para 56\% em 1970 de população urbana, tendo as migrações internas contribuído significativamente para esse incremento de população urbana. Oliveira (1982) atribui esse fenômeno à formação de um grande exército de reserva criado nas cidades para atender à nova demanda de mão-de-obra da economia industrial. Defende que esse processo ocorre na cidade em virtude da pretérita divisão social do trabalho existente no campo, escravocrata e aristocrática, que não oferecia as condições demandadas pelo novo industrialismo.

Shwartz (2006) não toma como certa essa relação direta migração x inchaço urbano, considerando que num primeiro momento o campo, sim, sustenta a indústria, mas quando se moderniza (proletarização) equaliza a reprodução da força de trabalho entre cidade e campo, e cessa o fluxo migratório e o exército industrial de reserva. Para ele, o urbano está em toda parte, como tendência, pela unificação da força de trabalho em torno do capital. A urbanização da economia e da sociedade brasileiras nada mais são senão a extensão a todos os recantos e setores da vida nacional, das relações de produção capitalistas: é contraditória. Dilui-se a dicotomia campo $\mathrm{x}$ cidade, e os problemas rurais se aproximam cada vez mais dos urbanos.

Em termos de problemas urbanos, Kohlsdorf (1976) aponta que a urbanização até a década de 1950 trazia apenas alguns problemas de infra-estrutura urbana, como energia, água, esgoto etc. No entanto, o rápido crescimento demográfico tornou a situação mais problemática, chegando aos setores de transporte e habitação, e atingindo posteriormente, nas décadas de 60 e 70, problemas ambientais graves devido principalmente ao avanço da industrialização e das ocupações irregulares nos grandes centros urbanos. 
"O quadro era de: proliferação de favelas, degradação do meio ambiente, aparecimento de uma periferia carente de quase todos os serviços urbanos; a aceleração da dinâmica de substituição e sucessão de usos do solo no espaço urbano, implicando a reciclagem ou demolição de vetustas edificações, por vezes com grande valor artístico, arquitetônico ou histórico; enfim, a consciência de a modificação no quadro urbano tradicional não era algo passageiro, mas uma nova característica na vida das cidades parecia se incorporar ao cotidiano" (SERRA, 1991, p. 37).

A partir do aprofundamento das contradições sociais devido à industrialização, urbanização, êxodo rural e outros problemas apontados, uma agenda mais especificamente urbana passou a ser colocada em pauta nos planos nacionais. Apenas na década de 1960 a necessidade de se pensar os sistemas urbanos com foco maior nas recentes transformações urbanas começou a ser considerada pelo governo. Kohlsdorf (1976) aponta que "os problemas urbanos demoraram a ser considerados como necessidades de desenvolvimento devido à centralização das atividades de planejamento", como era característico da tecnocracia da época.

Serra (1991) afirma que o "processo de urbanização acelerada promoveu imediatamente uma forte pressão de demanda por espaço urbano", com destaque para a necessidade de infra-estrutura das cidades brasileiras, equipamentos sociais e urbanos e os serviços públicos, passando a ser um tema "político, administrativo e científico".

À época do regime militar, o quadro da urbanização foi se consolidando em situações cada vez mais graves e exigiam por si mais que soluções meramente físicoterritoriais pontuais e desconexas de um eixo condutor. Considerava-se que a situação demandava uma atuação sistemática e coordenada, embasadas em estudos, diagnósticos, recursos humanos capacitados, órgãos de planejamento e aparatos institucionais e legais que subsidiassem a elaboração de políticas, programas, planos e projetos para a ordenação da urbanização em curso. Essa foi discurso "montado" pelo governo federal para atuar de forma mais "presente" junto aos problemas urbanos emergentes, passando o planejamento a se constituir em uma peça importante da estratégia de governo militar.

O planejamento urbano como disciplina e como prática de governo no Brasil com origens temporalmente referenciadas ainda no período militar (como comprehensive planning) passou por um período de obsolescência na década de 1980 
com a redemocratização, pela rejeição que foi criada ao planejamento tecnocrata e racionalista militar (COSTA, 2008, p. 67).

No "vazio" que foi deixado, o projeto neoliberal dos anos 90 ganhou espaço no campo do planejamento urbano com o modelo de "planejamento estratégico" de influência externa, mas voltado mais a grandes projetos urbanos de transformação de pontos específicos das cidades, com claro comprometimento mercadológico e completamente desvirtuado do entendimento de planejamento como "processo de longo prazo, compreensivo e contínuo" que, malgrado a sua cunhagem tecnocrática militar, guardava uma base metodológica que não era necessariamente desprezível, principalmente pelos estudos desenvolvidos para diagnósticos dos problemas urbanos.

\subsection{Do urbanismo ao planejamento urbano}

Diante das novas problemáticas e novas questões de pesquisa que a urbanização e seus fenômenos interferentes trouxeram, uma mudança de visão sobre a forma de se pensar a cidade a partir dessas novas complexidades, era mais do que necessária dentro do que ainda se chamava de "urbanismo" enquanto disciplina que tratava do espaço urbano.

A começar pela industrialização, a expansão da sociedade industrial imprimiu um caráter mais crítico e reflexivo ao urbanismo, diferenciando-o do estudo das artes urbanas como se dava anteriormente, principalmente pela pretensão científica que adquiriu (CHOAY, 2005). Muitos autores entendem que a Revolução Industrial foi o "marco zero" do pensamento urbanístico, isto é, da introdução "de uma abordagem reflexiva e crítica da cidade com vistas a preparar transformações por meio de projetos" (KOHLSDORF, 1996). Para a autora:

"a industrialização estimulou não apenas a reflexão sobre a questão
urbana, mas o surgimento da nova produção de urbanistas,
correspondente também à nova ordem social. Esse profissional surgiu em
função de problemas definidos pela sociedade industrial emergente e
necessitada de cidades preparadas para garantir um modo de produção
apoiado na indústria e essa no meio urbano"(KOHLSDORF,1996, p. 7).

Segundo Monte-Mór (2008), a partir do questionamento da cidade industrial e da própria sociedade capitalista moderna o urbanismo surgiu como uma nova área de estudos e pesquisas face ao contexto tecnológico cultural dos países desenvolvidos. 
Segundo o autor, a industrialização gerou uma desordem social e urbana tal que exigia um novo olhar sobre ordenação espacial (Idem, p. 33).

O fenômeno universal da urbanização, da aglomeração, da metropolização mudou a visão dos urbanistas e planejadores sobre os problemas urbanos, vistos de modo mais sistêmico e integrado com outras categorias de estudo, como as políticas, a economia, e as relações sociais. Esse processo de produção social do espaço que dá nova forma às cidades implica ainda em relações de poder, dominação, controle social, como também da expansão espacial, organização social, de divisão social do trabalho, e abre um vasto leque de intersecções com diversos campos disciplinares (SERRA, 1991).

Um dos principais campos que a partir de então se desenvolve é dos estudos de planejamento, visando além de compreender os processos que envolvem a formação das cidades, também planificar, mensurar, direcionar a ocupação desse espaço urbano em constante mudança (KOHLSDORF, 1996). A autora afirma que a introdução do planejamento veio de encontro a idéias do urbanismo, que até então se apresentavam com propostas muito idealizadas de como as cidades deveriam ser.

Segundo Kohlsdorf (1996), historicamente o planejamento urbano data do começo do século $\mathrm{XX}$, equivalente ao planning, que era "entendido como um conhecimento racional que objetivava a tomada de decisões para conduzir os processos urbanos em direção a certas metas previamente estabelecidas". Essa ideologia, consagrada após a segunda guerra mundial, torna-se um importante ferramenta do capitalismo internacional para organização do espaço em constante transformação.

Dentre os pensamentos vigentes na época, somente uma vertente apresentouse mais crítica desse pensamento "morfológico", a crítica marxista, cujas propostas transcendiam a compreensão puramente física e territorial das cidades e passaram a trazer a discussão para os planos sociológico, político e econômico, uma vez que compreendiam o espaço como socialmente construído por meio da luta de classes.

Após um longo embate entre a prática racionalista do planejamento (influência do projeto modernista) e a crítica marxista do planejamento (influenciada fortemente pela escola de sociologia urbana francesa), uma nova perspectiva do planejamento se 
configura após a Segunda Guerra. A perspectiva de intervenção estatal sobre o processo de desenvolvimento é aceito pelos países capitalistas como uma "técnica de aplicação de políticas", até o esgotamento desse projeto no final da década de 1980 , onde toma lugar um período de descrença e crítica no tipo de planejamento urbano e regional que se desenvolveu pelo Estado nas décadas de 1960 e 1970 (PIQUET E RIBEIRO, 2008).

Esse momento onde o planejamento desenvolvido pelo Estado militar foi o instrumento de organização do espaço nacional e depois foi "rejeitado" pelos próprios planejadores, é sem dúvida um momento marcante da história nacional, onde é desenvolvida a crítica ao planejamento a partir da sua própria prática, estatal e marcadamente racional, tecnocrata e progressista.

\subsection{O planejamento urbano e regional: a crítica e a prática}

O planejamento como atividade institucionalizada pelos poderes constituídos tornou-se ferramenta para o controle político dos processos sociais. Assim consagrouse o planejamento urbano como uma das atribuições do Estado, imbricando-se o desenvolvimento urbano no jogo de regras, atores e poderes que disputarão o "domínio" dessa técnica de ordenação do espaço urbano, com a "mediação" do Estado.

Para entender melhor sobre essa relação técnico-política do planejamento, a opção aqui colocada é de tratar-se primeiramente do planejamento urbano enquanto área do conhecimento e posteriormente do planejamento como ação estatal de intervenção sobre o desenvolvimento urbano.

\section{I}

Como visto, o planejamento urbano como área de conhecimento está intrinsecamente relacionado à prática de planejamento pelo Estado. Portanto, como área de conhecimento, coloca-se em um difícil papel de promover a crítica e reflexão temática ao mesmo tempo em que se coloca como instrumento "a serviço" do Estado. Ribeiro assinala essa dificuldade da seguinte forma:

"A área do planejamento urbano e regional encontra-se submetida a pressões que atingem a evolução orgânica do ensino, como exemplifica a rápida difusão de novas orientações teóricas e de método, mesmo quando são tratados temas tradicionalmente incluídos em sua dinâmica. 
Mas, o grande exemplo de pressão relaciona-se a mudanças na administração pública e em papéis assumidos pelo Estado. Para a área, esta última frente de processos possui especial relevância, na medida em que a ação do Estado encontra-se na sua origem, constituindo, portanto, um tema irrecusável de reflexão. E mais, as atuais mudanças na ação planejadora (e planejada) ultrapassam a preocupação com o Estado, atingindo os debates contemporâneos em torno do tecido social, como demonstra a valorização do cotidiano e do lugar; das articulações entre escalas na realização" (RIBEIRO, 2002, p. 64).

A complexidade dos fenômenos envolvidos e a multiplicidade de variáveis a serem consideradas no processo de produção social do espaço urbano tornam o campo do planejamento urbano uma área do conhecimento difícil de ser trabalhada isoladamente, de encontrar lógicas precisas, respostas imediatas, modelos de soluções. Trata-se de um conhecimento em constante mudança, porquanto seu objeto, a cidade, é tão mutante quanto suas variáveis interferentes - a sociedade, a economia, a política - esses tão dinâmicos e complexos quanto a própria disciplina.

Mas desde que os processos da vida urbana se tornaram mais complexos, com as mudanças sociais e econômicas trazidas pela indústria, correntes de pensadores tentam criar "modelos" que entendem ser no "seu" momento a resposta para mitigação desses problemas. Assim, teorias espaço-centradas, sócio-centradas, Estadocentradas, com maior ou menor nível de radicalização/moderação tomaram lugar ao longo da construção do domínio do planejamento urbano e regional, ou urbanismo como era entendido, dentre as quais se destacam o urbanismo técnico-setorial, 0 globalizante político, o socialismo utópico, a escola de Chicago e o modernismo racionalista, pra citar alguns (CAMPOS FILHO, 1999).

Campos Filho destaca especialmente a influência e penetração que teve o chamado "urbanismo técnico-setorial", que se propunha a ser um "instrumento técnico de melhoria da racionalidade da organização do espaço urbano e também das qualidades estéticas desse espaço, considerando essas qualidades visuais como desvinculadas de qualquer determinação mais profunda da organização social prevalecente", e que teve grande aceitação na Europa e nos Estados Unidos pelas cidades industrializadas deterioradas no pós-guerra, influenciando posteriormente as correntes do pensamento urbanístico posteriores (CAMPOS FILHO, 1999, p. 6). 
Essas questões colocadas para melhor entender o planejamento como método e como prática pelo Estado brasileiro quando da concepção da primeira PNDU, e que certamente causou impactos no contexto da segunda PNDU.

\section{II}

No Brasil, as primeiras idéias de planejamento estatal surgiram no rastro do desenvolvimentismo econômico da década de 1950, influenciadas pelo pensamento econômico da escola cepalina ${ }^{4}$ e de organismos estrangeiros como a OEA (Organização os Estados Americanos), que eram as referências para a formação de pessoal qualificado para atuar nos órgãos de planejamento recém-criados no País. $O$ foco era econômico, e as questões de desenvolvimento urbano e regional ainda eram tratadas perifericamente, em função da atenção dada ao planejamento econômico (PIQUET e RIBEIRO, 2008).

Somente no período militar no Brasil o planejamento urbano e regional é assumido como matéria de relevância na formação sócio-tecnológica brasileira, posteriormente incorporando-se novas vertentes disciplinares e deslocando-se da fase estritamente físico-territorial do pensamento urbano. São criados vários cursos de pósgraduação stricto sensu na década de 70 , antecedidos pelos órgãos de apoio ao planejamento criados pelo governo, como o IPEA (Instituto de Pesquisa Econômicas Aplicada) e o IPLAN (Instituto do Planejamento). Sobre a tônica dos cursos, Piquet e Ribeiro explicam:

"Nesses cursos predominava a formação voltada para as questões nacionais, uma vez que o projeto dos governos militares era transformar o país em uma grande potência no final do século. Acreditava-se que a senda para o desenvolvimento poderia ser trilhada por meio da elaboração de modelos econométricos e demográficos, baseados na geopolítica e na doutrina da Segurança Nacional. A ênfase nas disciplinas quantitativas - em que a Matriz de Insumo-Produto e os princípios da Programação Linear predominavam - e a crença nos princípios do planejamento racionalista dão o 'toque de classe' nos cursos da época. Novas influências se fazem presentes no planejamento territorial, como exemplificam a política francesa de aménagement du territoire e as propostas relativas aos pólos de crescimento. Ambas tiveram ampla aceitação nos meios técnicos e serviram de base a propostas de regionalização do território nacional e a estratégias de desenvolvimento" (PIQUET e RIBEIRO, 2008, p. 55).

\footnotetext{
${ }^{4}$ Ver nota (13) sobre a Cepal.
} 
Na sua origem nacional, o planejamento enquanto prática e enquanto disciplina enfrentou a dicotomia da análise crítica versus visão estatal do planejamento, ou seja, do planejamento enquanto instrumento das políticas urbanas estatais e da reflexão, enquanto campo de conhecimento que se coloca como fomentador da renovação do conhecimento e crítico/analítico dos processos urbanos em curso.

Segundo Costa (2008), ao longo do seu processo de aprofundamento enquanto campo de conhecimento sobre o urbano, o planejamento passou primeiramente do entendimento de cidades como loci de intervenções técnicas e de remodelação no começo do século XX - encerrando-se no que Monte-Mór (citado por Costa, 2008) classificou como uma "perspectiva de uma abordagem funcional intra-sistêmica do 'progressismo', habitação, trabalho, lazer e circulação - para a ótica disciplinar, baseada na economia, sociologia, engenharia etc."

A linha chamada de "compreensiva", entendia o planejamento como processo, dentro de uma perspectiva multidisciplinar e tinha na abordagem socioeconômica e territorial suas principais disciplinas. Essa fase do planejamento também sofreu a influência do racionalismo, baseando-se na idéia de que um "método abrangente, técnico e indutivo de análise urbana, resultaria na seleção racional de objetivos e prioridades, capazes de influenciarem as decisões políticas" (Idem, p. 69).

A metodologia do planejamento compreensivo, no entanto, acaba posta de lado pela associação do planejamento racional com a tecnocracia militar. Enquanto um processo que tem como base a análise contínua e compreensiva da produção e reprodução do espaço urbano, também encontra barreiras no novo contexto políticoeconômico da redemocratização, o Estado mínimo neoliberal. Inaugura-se o período em que o imediatismo e a necessidade das trocas transescalares da globalização, transferem o foco do planejamento territorial para a "gestão urbana" e para o "planejamento estratégico" que preconizaria a inserção das cidades na nova fase competitiva do capital.

Com as mudanças nacionais e internacionais, as quais afetam diretamente a produção do espaço nas cidades, novas disciplinas são incorporadas ao debate do

\footnotetext{
${ }^{5}$ Simultânea à centralização autoritária do governo militar, a metodologia compreensiva do planejamento foi institucionalizado pelo governo como justificativa da ingerência do governo federal sobre o planejamento local, preterindo-se a técnica às decisões políticas, como se verá posteriormente.
} 
planejamento, que além da dimensão socioeconômica e territorial, passa a considerar as dimensões política (também estrutural e histórica), espacial e ambiental na análise urbana, passando da abordagem transdisciplinar para a multidisciplinar, como enfatiza Costa (2008).

Nos rastros da crise internacional do petróleo que repercutiu fortemente nos países periféricos na década de 80 , e uma vez herméticas e inócuas boa parte das propostas de planejamento (principalmente planos diretores municipais) desenvolvidas nesse período, como visto, a credibilidade do planejamento foi comprometida pela sua associação ao "modus operand?" político militar - centralizador, autoritário e pouco eficiente.

O final da década de 1980 marca, então, o início da crise do planejamento urbano e regional, segundo Scherer (1995), enquanto área de conhecimento que precisou se reposicionar mediante as mudanças estruturais que se processavam no momento: de escalas territoriais, de diretrizes econômicas e, claro, de como o Estado reagia ou se amoldava ao novo circuito internacional do capitalismo. Scherer não reduz o plano a somente um relatório técnico sem efetividade, mas o enxerga como a possibilidade de ser "uma agenda de compromisso político" governamental.

Essa "agenda de compromissos políticos" pode ser entendida também como as decisões do Estado para sua intervenção no urbano, ou seja, as decisões políticas, para o que o planejamento urbano serve tanto como ponto de partida para compreensão de uma realidade, como instrumento de ação concreta, no caso de uma política urbana.

Costa (2008, p. 72) destaca que as imprecisões conceituais do planejamento têm levado a usos diversos associados com os planos diretores, com os planos de governo, como instrumentos da política urbana, de legislação urbana, etc. $O$ autor ressalta que além da questão prática da implementação, não se pode perder a dimensão analítica do planejamento, que deve sempre pautar os processos urbanos em curso.

Entre a formulação da política, o planejamento e a execução do plano são muitos os caminhos, meandros, interesses, conflitos, articulações, negociações, que dificilmente se enquadram na rigidez e linearidade do racionalismo ou positivismo. Por 
isso, o planejamento urbano e regional, como área de conhecimento, tende a - e deveposicionar-se criticamente e propositivamente frente a práticas muitas vezes inócuas que deram margem, ou objetivamente fomentaram, o desenvolvimento urbano concentrador, segregador, excludente, reflexo de políticas urbanas igualmente concentradoras, segregadoras e excludentes, apesar dos discursos oficiais demonstrarem intenções de amenizar esse quadro urbano.

Para Martins (2003) o significado do urbanismo ou do próprio desenvolvimento urbano se concretiza quando a cidade é percebida mediante os benefícios urbanos, resultados do planejamento - por essência - da ação do Estado. Para a população excluída, a inserção - como inclusão - é prioritária. Portanto, a questão urbana tende a se mostrar mais como uma disputa por espaço social do que como um debate puramente urbanístico.

Para a autora, verifica-se que o conflito de classes se exprime "à medida que os grupos excluídos redefinem a noção de cidade conforme suas efetivas necessidades," esperando-se que os movimentos populares urbanos construam essa redefinição no sentido de ressaltar que a cidade tem papéis e funções diferentes para cada grupo. "Remete-se assim a questão urbana para mais do que uma disputa pela forma e qualidade do espaço ou uma relação reivindicatória com o Estado (mais serviços, mais equipamentos), mas para uma verdadeira disputa na sociedade" (Idem, p. 49).

Nessa disputa social o Estado é, por princípio, o regulador dos conflitos, e com isso não deixa de abrir mão de ferramentas ideológicas para cumprir seus objetivos.

\section{III}

Cintra afirma que "o planejamento, não como um arquétipo intelectual, mas como um conjunto de orientações exeqüíveis e de comportamentos reais dentro de uma maquinaria governamental, associa-se inevitavelmente ao poder" (CINTRA, 1978, p. 172). O poder não apenas como um instrumento, mas também em sua substância, ou seja, do ponto de vista "das coisas que permite aos diversos atores alcançar". Ou seja, o planejamento é associado a uma ferramenta de poder para determinado grupo de atores. 
Como preconizava Marx, o planejamento urbano entra para o rol de elementos de disputa entre os diversos atores sobre o espaço, e entre o "capital e o proletariado", uma vez que o próprio espaço urbano é colocado como objeto de disputa e lugar de conflito dos diversos interesses que nele se manifestam.

Nesses conflitos, a ideologia é um forte instrumento nas mãos do Estado, por meio do seu discurso, e o espaço urbano é uma categoria "privilegiada" de produção dessas ideologias. Villaça (2004) afirma que isso se refletiu diretamente na forma de desenvolvimento do planejamento urbano no Brasil, utilizando-se da crença na ciência ou razão e na tecnocracia como as chaves para a solução dos problemas urbanos, e essa função essencial foi dada ao Plano Diretor, que deveria cumprir esse papel "salvador".

Scherer (1995, p. 64) apresenta uma visão semelhante quando entende o planejamento também como forma de controle social, portanto, "prática conservadora, historicamente datada que constitui desde o final do século XIX alternativa implementada para a superação da crise macroestrutural do capitalismo e que só apareceu plenamente no século XIX e no Estado de Bem-Estar social".

Para a autora, planejamento não se trata apenas dos aspectos de simples previsão do futuro, encadeamento de atividades, levantamento de verbas e procedimentos de implementação, mas deve ser historicamente contextualizado, porquanto sua especificidade consiste em buscar argumentos para a legitimação da ação política do Estado. Nesse sentido, a autora defende que tanto o planejamento na acepção moderna, quanto o planejamento urbano no século XX, com a legitimação do Estado de Bem-estar Social (nos países centrais) operando os requisitos do capital monopolista financeiro, se inserem no rol de "papéis que o capital espera que o Estado cumpra para assegurar sua reprodução ampliada".

No Brasil, o planejamento urbano em seu período áureo (décadas de 60 e 70) produziu reflexão crítica e serviu à administração pública, até a sua crise, no final da década de 1970 e início dos anos 80. Nesse período de "transição", Monte-Mór (2008) destaca uma situação ambígua do planejamento urbano: a nova Constituição de 1988 determinava a obrigatoriedade de Planos Diretores, mas não havia ainda Política Nacional de Desenvolvimento Urbano que os direcionasse, fadados, portanto, a tomarem os mesmos rumos de inocuidade de outrora. 
Fazendo um balanço da história do planejamento urbano no Brasil, Rolnik (1994) registra uma trajetória marcada pela concepção de cidade e de estratégia de intervenção na política urbana que tem como base a concepção uma "visão que alia a tradição do urbanismo higienista, em sua versão funcionalista pós-Carta de Atenas, a uma Economia Política Desenvolvimentista com forte protagonismo do Estado". E vale a pena destacar ainda o que a autora coloca, a partir da visão da Economia Política, como os "pressupostos do paradigma que tem presidido as intervenções via planejamento urbano e seus instrumentos":

(i) "uma gestão urbana fundamentada por um processo estatal de tomada racional de decisões, orientado para lograr implantar uma cidade de acordo com um modelo de ordem urbana ideal, não-contraditória, oposta tecnocraticamente a uma realidade vista como anárquica;

(ii) um modelo ideal de cidade como parte de um projeto 'modernizador' e 'integrador', que tinha por objetivo eliminar as contradições geradas por um processo de urbanização rápido que implicava em desterritorialização de parte considerável da população;

('iii) garantia de fluxos contínuos de investimentos, principalmente federais, em infra-estrutura básica, garantindo as condições gerais de reprodução do capital".

Esses três pontos retratam bem as idéias e práticas que com freqüência estão subjacentes e justificam as políticas e planejamento do Estado, principalmente no contexto da primeira PNDU. Vê-se, então, que a ação planejadora do Estado tem sido permeada pela relação entre o discurso e a prática - muitas vezes contraditória - e entre a prática e a política - na maioria das vezes paralelas - com um ordenamento do espaço urbano que se efetiva tanto através do planejamento urbano quanto da política urbana, ou seja, pelas decisões e diretrizes do poder público para o desenvolvimento urbano.

Essas decisões e diretrizes podem assumir uma forma de imposição de idéias e crenças à sociedade, às vezes importados, como já se viu, de caminhos que nem sempre são os mais adequados às "soluções" dos problemas urbanos, mas atendem aos interesses da minoria privilegiada pelo Estado e seus "donos", ao que Schmidt (1983) classifica como uma "tentativa sistemática de enfrentar as externalidades causadas pela economia de mercado, e corretivos para as disfunções urbanas pelo Estado". Maricato assim pontua essa questão: 
"É engano freqüente considerar que as cidades periféricas estão num estágio mais atrasado em relação ao percurso seguido pelas cidades do mundo desenvolvido e que um esforço de gestão e condições favoráveis de governabilidade é suficiente para superar o gap entre elas. Não faltam receitas que são oferecidas por agências internacionais e consultores que têm origem nos países do norte para superar essa distância. É evidente que determinados governos urbanos, em determinadas condições políticas e econômicas, podem minorar as mazelas das cidades mais pobres e isso não é pouco importante. Mas o que se quer destacar aqui é que jamais será possível equipará-las com as cidades desenvolvidas mantendo a relação de dependência subordinada e utilizando receitas do primeiro mundo. Isto porque elas são estruturalmente diferentes e não estão em diferentes etapas de um mesmo percurso histórico rumo ao desenvolvimento" (Maricato, 2010, p. 10).

\section{IV}

Complementando-se a linha de argumentos sobre o uso ideológico do planejamento pelo Estado, não se poderia deixar de abordar o tema da geopolítica, que trata mais especificamente das estratégias de articulação política de um governo para organização territorial de uma nação, visando atender objetivos tanto internos, quanto externos de seu posicionamento político diante das relações de poder nacionais e mundiais.

Andrade entende que "o saber geopolítico compreende uma tentativa de análise científica da importância dos Estados, em face de sua extensão, da sua população e de sua posição geográfica, integradas em ideologias que procuram estimular e provocar a realização de objetivos de expansão territorial e de dominação dos Estados vizinhos que impedem ou dificultam a realização de aspirações da classe dirigente" (ANDRADE, 1989, p.7). Nessa afirmação o uso da "ideologia" no atendimento às aspirações das classes dirigentes representa bem a estratégia geopolítica brasileira utilizada desde a era varguista e reforçada no governo militar.

Desde a sua colonização até o começo do final do século XIX, a geopolítica brasileira foi utilizada pelas classes dirigentes em virtude da necessidade de definição e ampliação dos limites territoriais, tendo em vista os interesses econômicos e expansionistas principalmente. A partir do início do século $X X$, sob a influência da escola francesa, o pensamento geopolítico nacional assume contornos mais expressivos e preconizam a reordenação territorial nacional para ocupação das áreas ainda parcamente povoadas e a instalação de um Estado forte e autoritário. Não coincidentemente esse "movimento" se inicia após a instalação do Estado varguista, que cria o IBGE - Instituto Brasileiro de Geografia e Estatística, a fim de promover a 
formulação de uma política de racionalização de utilização do território nacional (ANDRADE, 1989).

Miyamoto (1995, p. 16) aponta que os estudos geopolíticos surgiram no Brasil com Elyseo de Carvalho, fazendo uma abordagem mais técnica, e mais posteriormente foram aprofundados por Everardo Backhauser, com forte viés ideológico. Segundo Bomfim (2007), pode-se dizer que houve uma escola brasileira de geopolítica, cujas formulações permearam as principais diretrizes de planejamento, associando o instrumental governamental com uma burocracia técnica emergente, num contexto em que o autoritarismo político e o militarismo estavam na situação do poder. Os principais temas desses estudos, segundo Miyamoto (Idem) seriam "a centralidade da capital nacional, a geopolítica das fronteiras e a implementação das redes de transporte para integração nacional".

O projeto ideológico que estava em voga no período militar explica o contexto, os valores e propósitos que estavam em jogo no momento ${ }^{6}$ em que as cidades, as regiões e o território nacional passavam por mudanças que demandavam uma "intervenção" estatal no direcionamento do desenvolvimento em curso. Foi no desenrolar desse contexto que se esboçaram as primeiras tentativas de desenvolvimento de um planejamento urbano e regional nacionais, em que pese toda a problemática e estigma a que ficou sujeito o planejamento urbano desse período e, por conseguinte o atendimento à necessidade de criação de uma política urbana nacional, na forma de definição de diretrizes gerais para o planejamento urbano.

Bomfim (2007), em sua pesquisa sobre a geopolítica nacional, investigou a atuação do Estado brasileiro como agente indutor da ocupação do território, ou seja, como as políticas territoriais dos governos militares se sustentaram dentro do I e II Planos Nacionais de Desenvolvimento (PND), o primeiro desenvolvido de 1971 a 1974 e o segundo de 1975 a 1979. Para o autor, estava em pauta a cristalização de uma ideologia interventora do Estado, cuja preocupação central imbuía-se da intenção de promover a ocupação territorial nacional, buscando dotar o território brasileiro de uma densa e vasta rede de comunicação. É nesse contexto, de planos econômicos e

\footnotetext{
${ }^{6}$ Apesar do destaque mais evidente do pensamento geopolítico no período militar, pode-se dizer que essa estratégia de projeção nacional no jogo do poder mundial passou a permear de forma nítida o planejamento nacional, uma vez que os planos, principalmente, econômicos e a política internacional empreendida (desde o governo Collor, Fernando Henrique e agora Lula) desde então têm logrado êxito na projeção internacional do Brasil frente à América do Sul, e agora frente ao cenário mundial.
} 
ideologia interventora de Estado, que se concebe a primeira política nacional de desenvolvimento urbano.

\subsection{A política urbana: conceitos, direitos e instrumentos}

I

A política urbana é primeiramente uma política pública, e como tal, pode designar todas as atuações do Estado e as formas de intervenção do poder público sobre a vida urbana, caracterizando uma atuação do Estado cada vez maior na forma de agir, no comportamento da Administração Pública e na coordenação e no planejamento do desenvolvimento econômico (Eros Grau citado por SAULE Jr.,1998).

Saule Jr. entende que a partir das políticas públicas são determinados o planejamento, os programas, planos de ação e projetos que consubstanciam a política urbana. O plano seria o principal instrumento de planejamento, e que "materializa a política pública, os objetivos, as diretrizes, as metas, os órgãos do sistema de gestão, os instrumentos e procedimentos da política, que devem ser estabelecidos por lei" (SAULE Jr., 1998, p.9). No campo da política urbana, isso se materializa principalmente a partir da nova Constituição de 1988, que inclui de forma específica a "Política Urbana Nacional".

Reis Filho (1996, p.10) afirma que "uma política é uma proposta de controle de um processo, isto é, dos movimentos de um conjunto de relações que apresentam regularidade, sendo sempre e necessariamente referida a um determinado conjunto de relações e aos seus movimentos, vale dizer, à evolução ou desenvolvimento de um processo". Uma política de desenvolvimento urbano seria, portanto, "um projeto de controle dos movimentos (evolução ou desenvolvimento) do processo de urbanização em uma sociedade, que pretende orientar a configuração espacial dessas relações, no que se refere ao meio urbano, e atua diretamente sobre as condições de apropriação, produção, uso e transformação do espaço urbano".

O campo de definições da política urbana passa necessariamente pela sociedade e seu território, lócus principal do conjunto de relações e das reproduções sociais a que os autores se referem, e o Estado é o mediador e regulador dessas relações na produção e reprodução do espaço urbano, sendo, portanto, propostas e 
ações reais do Estado sobre o urbano, que podem ser implementadas por diferentes instâncias (pode-se entender instâncias governativas do poder público), como afirma Villaça (2001).

Ao tratar da política urbana, Castells (1983), distingue "o político", que é a instância das reproduções sociais, e "a política", que designa o sistema de relações de poder. Para esse autor, "o espaço teórico do conceito de poder é o das relações de classe", e se define "pela capacidade de uma classe social em realizar seus interesses objetivos e específicos à custa dos outros" (Castells, 1983, p. 373-374).

No caso da política urbana a relação é entre "quem" decide, ou seja, as relações entre os atores, como "o quê" e "como" se decide, ou seja, o espaço e sua planificação. Para o autor, "o estudo da política urbana se decompõe em dois campos analíticos indissoluvelmente ligados à realidade social: a planificação urbana sob suas diferentes formas, e os movimentos sociais urbanos. Existe, portanto, por um lado, "o estudo da intervenção dos aparelhos de Estado, em todas as suas variantes, sobre a organização do espaço e sobre as condições sociais de reprodução das forças de trabalho" e, por outro, "o estudo da articulação das lutas de classe, compreendendo também a luta política, no campo de relações sociais". (Idem, p. 374).

\section{II}

As definições colocadas inserem o presente trabalho no campo dos estudos da intervenção do Estado, ao focar sua política de Desenvolvimento Urbano em dois distintos momentos: 1975 e 2004, e a partir então se reporta esse debate ao contexto nacional.

Para Serra (1991, p. 24), quando as autoridades federais no Brasil se reportam a uma política urbana, "estão falando de um conjunto de problemas, em geral reunidos sob a denominação de questão urbana", ou então se referem "à distribuição espacial das atividades econômicas e das populações". Segundo o autor, "no primeiro caso, quase sempre emergirão conflitos ao nível da autonomia municipal, no segundo caso, pode-se notar umas das mais interessantes contradições entre o discurso e a ação"7 .

\footnotetext{
7 Tendo pesquisado também sobre a PNDU de 1975, com essa afirmação Serra já introduz a problemática que permeará a pesquisa ao longo da tese: a ambigüidade do Estado e seu discurso e uso da política e do planejamento urbano.
} 
Assim como o planejamento urbano, a política pública é a própria forma de atuação do Estado, e toma seu lugar na história principalmente nos momentos em que o Estado tem que assumir de forma mais contundente, ou seja, intervencionista, o curso das decisões nos mais variados aspectos do desenvolvimento nacional, como a economia, a política e as questões sociais.

E é após a Segunda Guerra Mundial que os Estados mais tradicionais, principalmente devido a pressões sociais, avançam seu escopo de atuação sobre a ordem social, ampliando as garantias sociais à saúde, educação, habitação, inaugurando as era dos Welfare States, ou Estados de Bem-Estar Social ${ }^{8}$, com destaque principalmente para países europeus como França, Inglaterra e Alemanha (SAULE Jr.,1998).

Essa nova "onda" de garantias sociais inaugura a geração dos chamados "direitos sociais", entre eles, os direitos difusos ${ }^{9}$, nos quais se enquadra o direito à cidade (ALFONSIN, 2008). Essa inovação jurídica, no qual o Brasil se torna um dos pioneiros, traz a idéia do direito à moradia, do direito à terra, ao saneamento, ao transporte, enfim, estende aos aspectos relativos à vida urbana de qualidade a noção desses direitos, como garantias pelo Estado de acesso à cidade. Reforça-se a função social da cidade, complementada pela determinação constitucional da função social da propriedade, baseados na nova fundamentação jurídica do "direito à cidade". Segundo Alfonsin (2008), o Estatuto da Cidade, ao regulamentar o capítulo da política urbana da Constituição Federal, acabou por definir o conteúdo deste direito difuso da seguinte maneira:

Art. 20 A política urbana tem por objetivo ordenar 0 pleno desenvolvimento das funções sociais da cidade e da propriedade urbana, mediante as seguintes diretrizes gerais: I - garantia do direito a cidades sustentáveis, entendido como o direito à terra urbana, à moradia, ao saneamento ambiental, à infra-estrutura urbana, ao transporte e aos serviços públicos, ao trabalho e ao lazer, para as presentes e futuras gerações (BRASIL, 1988).

\footnotetext{
8 O Estado de Bem-estar social toma lugar no Brasil, ou pelo menos, tenta aqui se instalar, principalmente na década de cinqüenta, e vai se desmontando paulatinamente até que a força do Estado Nacional sucumbe mediante as investidas do mercado de inclinação fortemente liberal, num movimento global, mas de clara inspiração norte-americana, de supressão da escala nacional de atuação, em favor do "empresariamento das cidades" e do seu grupo de donos.

9 Segundo ALFONSIN, "o ordenamento jurídico aplicável às cidades não está mais fundado na supremacia liberal do direito de propriedade, mas na reinterpretação deste direito individual que é agora permeado por interesses difusos da sociedade, como são exemplos a função social e a função ambiental da propriedade".
} 
Conclui a autora que o "enunciado deste direito à cidade introduz no ordenamento jurídico um direito difuso, de titularidade transindividual, inteiramente novo, inclusive no cenário jurídico internacional, já que em outros países a idéia de "direito à cidade", com conteúdo jurídico, é ainda desconhecida".

A Constituição de 1988 reforçou, então, a mudança da noção do direito de propriedade, privilegiando a coletividade em detrimento da individualidade, e sentenciando o mau uso da propriedade urbana. O cumprimento da função social da cidade é matéria constitucional de primeira importância dentro do Estatuto da Cidade, lei que regulamentou o Capítulo da Política Urbana, visando que o uso do solo urbano possa atender prioritariamente as necessidades de habitação, saneamento, transporte, serviços públicos, trabalho, lazer, sendo esses os objetivos precípuos da política urbana, dentro da nova categoria dos direitos difusos (MARICATO e SANTOS JR, 2007).

Como visto, está no próprio "caput" do artigo 182 da Constituição Federal de 1988, a função da política urbana nacional, que deve "ordenar o pleno desenvolvimento das funções sociais da cidade e garantir o bem-estar de seus habitantes". A complementação do entendimento dessa função que veio posteriormente com 0 Estatuto deu mais subsídios e direcionamento ao conteúdo do artigo 182, e definiu as diretrizes gerais da política de desenvolvimento urbano e os seus "instrumentos" técnicos, financeiros, jurídicos etc.

Os instrumentos da política urbana são ferramentas essenciais para a implementação de suas diretrizes. Conceitualmente, ainda são bem inespecíficos, mas no contexto mais recente, principalmente após a aprovação do Estatuto em 2001, vêem-se muitos debates sobre os "instrumentos da política urbana" pautados pela regulamentação da nova PNDU. O Estatuto claramente determina como instrumentos gerais da política urbana os programas, planos e ações, e o próprio planejamento regional e municipal do desenvolvimento urbano, bem como os que a lei chama mais especificamente de "institutos" da política urbana.

Pelo Estatuto, os instrumentos das políticas urbanas podem ser entendidos como os elementos legais, financeiros, técnicos ou institucionais, que servem de suporte à elaboração e implementação dessas políticas. Assim, os mecanismos 
financeiros, como fundos, a distribuição e o repasse de recursos para os programas, a engenharia fiscal, compõem os instrumentos financeiros; as diversas leis relativas ao uso do solo urbano, (zoneamento, uso do solo, códigos de obra, leis orgânicas, o Estatuto), ou relativas à gestão urbana e regional (criação de metrópoles, municípios), ou de cooperações intergovernamentais, compõem os instrumentos legais; os programas, os projetos, os planos (como os Planos Diretores, que podem ser também considerados instrumentos legais), e seus mecanismos de ação e organização do solo (como a "caixa" de ferramentas do Estatuto); assim como o aparato "técnicoburocrático" a ser criado para suporte à implementação desses instrumentos.

Outra parte essencial dos chamados "instrumentos" de políticas urbanas são os relativos à parte institucional, os instrumentos de gestão, entendidos como os arranjos institucionais que deveriam facilitar o trâmite dessas políticas, uma vez que tratam do interesse "público", mas que por vezes servem de entraves à própria criação e aprovação das políticas. Esses instrumentos situam-se principalmente no campo das relações intergovernamentais e federalistas, como a capacidade de cooperação e articulação dos entes federados para tratar, gerir e solucionar problemas comuns.

\subsection{Federalismo: o sistema e o pacto}

O federalismo como forma de organização do Estado, diz respeito principalmente à relação estabelecida entre as unidades que compõem a federação, ou seja, o pacto mantido entre elas, que determinam o grau de centralização, autonomia e soberania de cada uma dos entes.

Justamente sobre essa noção de regras, Souza destaca que a mais conhecida e sintética definição de federalismo foi formulada por Elazar (1984, citado por SOUZA, 2003): self-rule/shared rule, ou seja, regras próprias/regras partilhadas. "Essa aparentemente simples definição esconde, no entanto, um sistema altamente complexo e eivado de tensões. Isto porque a construção e manutenção de um sistema político voltado para a divisão de poder territorial, tanto político como tributário, sem promover desequilíbrio entre os entes constitutivos, é tarefa intrinsecamente contraditória, gerando, portanto, conflitos e tensões" (SOUZA, 2003, p. 142). 
Segundo Abrucio (2005), três características principais compõem uma federação, de modo geral. A primeira delas é a autonomia dos governos subnacionais, admitindo-se uma multiplicidade do poder entre os demais entes, e não só do governo central. Por outro lado, a interdependência demanda a existência de um pacto cooperativo entre os governos, com certo grau de centralização necessário para a manutenção do Estado Nação, através de regras e instituições comuns. Uma terceira característica seria a idéia de república, no sentido de existência de uma "coisa pública", que é também de uma sociedade, e permite certo controle social.

Amaral Filho (2000) aponta ainda a coordenação (pela União) como um dos princípios do federalismo, e a existência de um equilíbrio estrutural, ou seja, de certa paridade entre os entes. Esse autor apresenta ainda três formas de federalismo: o piramidal, com centralização e autonomia relativa para os entes federados; a horizontal, com descentralização, autonomia e cooperação entre os entes; e o federalismo multilateral, com autonomia, cooperação (vertical, horizontal) e coordenação da União. Em todas as formas, a União tem o papel redistribuidor para manter o equilíbrio estrutural entre as partes.

Ainda segundo Amaral Filho, a forma de gestão centralizada ou descentralizada do Estado federado determina o grau de poder, de liberdade e autonomia que se permite na relação entre os governos nacionais e subnacionais. Geralmente, Estado centralizado e descentralizado são colocadas como classificações antagônicas das formas de federalismo, quando na verdade pode haver uma coexistência das mesmas, na medida em que se pode ter uma administração descentralizada, mas uma política fiscal centralizadora, bem como a existência de uma burocracia centralizada etc.

Também diz respeito a uma maior ou menor concentração de poder decisório nas mãos do governo central. Segundo Amaral Filho (2000), "seu objetivo é o de realizar uma redivisão de benefícios e obrigações dentro da qual ocorre uma maior transferência de poder e de autonomia de decisão e de gerência, do governo central para os governos subnacionais". Numa definição mais concertada entre autores, a descentralização pode ser entendida como transferência de poder decisório para 0 município ou entidades e órgãos locais. 
As federações podem ainda ser homogêneas, ou seja, há uma relativa paridade entre as unidades federadas, como é o caso dos Estados Unidos e Canadá, ou heterogêneas, como no caso brasileiro, com uma grande disparidade regional, em termos econômicos, sociais, culturais etc. A adoção do sistema federalista em uma nação visa atender, portanto, a necessidade de integração nacional, unindo os entes federados, mas mantendo a sua autonomia, a fim de fazer funcionar o Estado, dentro do que se convencionou chamar de "pacto federativo".

A idéia de "federação" em si traz à luz a noção de "pacto", de "união" de "articulação das partes (estados) com o todo (nação), por intermédio do governo central ou federal", como cita Affonso (1995, p. 57). Para esse autor, o que se entende por "pacto federativo consiste, na verdade, em um conjunto de complexas alianças, na maioria pouco explícitas, soldadas em grande parte por meio de um fundo público".

Sobre o federalismo nacional, Affonso afirma ainda que essa noção de "pacto" não é bem associada ao federalismo, e sim, a idéia de "descentralização", ligada mais aos estados e municípios, principalmente nas últimas décadas, em que se observa a fragilização do pacto federativo. Dentro desse pacto, o papel da distribuição dos recursos é a "liga", o elemento de "soldagem" da articulação nacional. Ou seja, a compreensão da configuração do federalismo fiscal nacional é essencial dentro do entendimento da organização federativa nacional.

Dentro do federalismo, as relações intergovernamentais podem ser um dos fatores que mais implicam na formulação das políticas públicas. A estrutura federalista ao mesmo tempo em que garante a divisão de poderes, por outro lado, pode dificultar a tomada de decisões, uma vez que as competências de um e de outro governo podem ser concorrentes, ou seja, pode haver interferência, na implementação de certa política. Mas, como alerta Arretche (2002), a baixa integração vertical e horizontal dos estadosmembros trazem sérios constrangimentos às mudanças de status quo, ou seja, à aprovação de políticas que tragam impactos e transformem a realidade vigente.

"A literatura comparada contemporânea considera que as características institucionais dos estados federativos operam no sentido de restringir as possibilidades de mudança do status quo. A afirmação central é que a natureza das relações vertical e horizontal em estados federativos dispersa a autoridade política e potencializa o poder de veto das minorias" (ARRETCHE, 2002, p. 431). 
No contexto brasileiro, o federalismo e as relações governamentais têm sua história claramente marcada pelas disputas entre os entes federados e pelo clientelismo na provisão de recursos e, e ainda pelas tentativas recorrentes do governo federal, mesmo em momentos de discurso "descentralizador", concentrar poderes ou criar mecanismos de subordinação dos subgovernos às decisões centrais. Seja no período ditatorial, seja na transição e "consolidação" democrática, as velhas práticas coronelistas e clientelistas de barganha entre os governos parecem assumir novas formas nas relações políticas e institucionais do país.

No contexto federalista, as várias instâncias de gestão e instituições que as regem implicam na própria decisão de existência de uma política urbana, bem como os mecanismos institucionais disponíveis para sua execução. A questão da interferência das instituições no arranjo federativo tem a ver com maior ou menor capacidade de aprovação de mudanças, levando-se em consideração as regras do jogo no funcionamento da política nacional.

Historicamente, viu-se a constante oscilação constitucional sobre a questão da centralização, devido principalmente a disputas da burocracia federal e as elites regionais na tentativa de fazer valer seus interesses específicos, o que em acordos e coalizões acabam por aproximar suas preferências e decidir pelo que for de comum acordo.

Sabe-se que para que uma política saia do mero desejo de um grupo ou de uma burocracia e venha a ser um instrumento aplicável no contexto de desenvolvimento urbano é necessária a aprovação em várias instâncias e por vários atores, de forma que os interesses dos grupos envolvidos possam ser viabilizados dentro das combinações possíveis do sistema.

Nesse contexto, ser ou não um estado federativo ou centralizado importa para a aprovação de políticas. No estado unitário, os governos locais dispõem de menos autonomia e o governo teria maior capacidade de coordenação das políticas. A estrutura quando federalista dispersa a autoridade do Estado, na medida em que os governos locais são autônomos, afetando sua capacidade coordenar as políticas, onde forças independentes podem disputar poder com as burocracias. Esta descentralização do Estado eleva os custos de ação da burocracia. Nesse caso o federalismo inibiria a formulação de políticas de âmbito nacional, favorecendo as políticas locais. 
Corroborando o que acima está dito, segundo Arretche (2004):

\begin{abstract}
"Estados federativos são encarados como propensos a produzir níveis comparativamente mais baixos de gasto social, bem como menor abrangência e cobertura dos programas sociais. Tenderiam ainda a tornar mais difíceis os problemas de coordenação dos objetivos das políticas, gerando superposição de competências e competição entre os diferentes níveis de governo, dada a relação negativa entre dispersão da autoridade política e consistência interna das decisões coletivas. Adicionalmente, a existência de uma multiplicidade de pontos de veto no processo decisório implicaria que, em Estados federativos, as políticas nacionais tenderiam a se caracterizar por um mínimo denominador comum" (Idem, p. 17).
\end{abstract}

Numa estrutura federalista e descentralizada, o papel dos atores nos processos de formulação de políticas públicas pode assumir uma importância fundamental. E essa participação ou interferência no processo torna-se proporcional ao acesso ao poder, ou pelo menos, proximidade de quem tem acesso ao poder. $\mathrm{O}$ ator como indivíduo ou como grupo tem a capacidade de influenciar as decisões ou, por meio de lobby, garantir que seus interesses sejam atendidos.

Uma reflexão sobre a influência de indivíduos ou grupo desenvolvida nas teses de Marques ${ }^{10}$ sobre as redes sociais e suas interferências nas políticas públicas destaca que a importância desses atores está na sua capacidade de realizar ações baseadas em seus destacados recursos de poder, assim como na ocupação de determinadas posições na cadeia de produção das ações do Estado (dentro e fora dele), que Ihes conferem maior ou menor capacidade de fazer com que o Estado elabore e execute políticas segundo seus interesses particulares. A centralidade da importância das redes está nas relações e posições dos indivíduos, que constituem elementos estruturais que podem influenciar escolhas, fluxo de informações, bens e recursos de poder a alterar os resultados das políticas (MARQUES, 1997).

Para Castells (1983), o poder se revela nas lutas de classe, as quais são reguladas e "intermediadas" pelo Estado. "As políticas" definidas no contexto urbano, são entendidas por esse autor como uma ação do Estado. O Estado, então, intervém no urbano, intermediando essa luta de classes, que são lutas pelo poder, através da

\footnotetext{
10 Em um contexto mais teoricamente substanciado sobre redes, a policy network é o campo das ciências políticas que estuda as relações entre as políticas públicas e as redes, e tem como foco as relações organizacionais para a explicação das influências das redes de grupos de interesse na formulação de políticas públicas frente a um determinado problema (Marques, 2006).
} 
formulação de políticas públicas ${ }^{11}$. Então, a relação da sociedade com Estado no processo de tomada de decisão pode-se dar em diferentes níveis de influência, que são delimitados pela maior ou menor possibilidade de pressão de um maioria sociedade, ou de um grupo restrito, sobre as instâncias estatais.

Pode-se dizer que esse quadro revela claramente o poder de influência de certos grupos dominantes - uma burocracia elitizada e uma oligarquia favorecida - que interfere nos processos de decisão, podendo resultar em um planejamento distorcido e desequilibrado, da maior à menor escala espacial, enquanto os alijados do poder, os demais grupos sociais, principalmente os movimentos populares, são postos à margem dos processos de planejamento territorial e urbano, e se vêem por vezes desprovidos da capacidade de influenciar os rumos do desenvolvimento urbano.

O fato de se ter instalado no poder um centralismo autoritário ou uma descentralização democrática, como é o caso dos contextos antagônicos das políticas urbanas federais em estudo, determina diretamente essa "permeabilidade" do Estado para a sociedade. A luta de classes está sempre presente e, é inerente às relações sociais, mas a negação do conflito ou a abertura ao diálogo são efeitos sentidos diretamente no processo de tomada de decisões e nos direcionamentos tomados, nas mudanças (ou não) e impactos sobre o espaço o urbano.

Nesse ponto, argumenta-se que a esfera local seria mais adequada para lidar com essas questões das cidades, por estarem mais próximas dos cidadãos, das demandas diretas dos habitantes. No entanto, apesar da autonomia dada aos municípios a partir de 1988, esse parece permanecer ainda como "elo mais fraco da corrente", pela sobrecarga de responsabilidades, e insuficiências de recursos financeiros, técnicos, institucionais etc.

\footnotetext{
${ }^{11}$ Daniel (1988, p. 26) preocupa-se em distinguir o poder político local do poder local. Para esse autor, o poder político local constitui-se em uma esfera do Estado capitalista, cujos "lugares de exercício consistem no governo e administração local e câmara municipal". Em outro momento, o autor apresenta duas categorias de poder local: o poder "econômico" local, de caráter material, representado pelo conjunto dos setores capitalistas, e o poder "social" local, de caráter mais simbólico, representado pelas classes sociais.
} 


\section{Capítulo 2}




\section{$\mathbf{C}_{\text {APitulo2 }}$}

\section{POLÍTICAS DE DESENVOLVIMENTO URBANO NO BRASIL}

No contexto histórico do planejamento e das políticas no Brasil revela-se uma ação majoritariamente marcada por políticas voltadas às minorias privilegiadas (burocracias, classes sociais, grupos políticos), seja política ou financeiramente, de uma forma geral - de coronéis a industriais e ao mercado financeiro - quase sempre ligada ao atendimento de interesses políticos e econômicos de um grupo minoritário.

Como decorrência, a organização do território nacional e a definição de diretrizes de desenvolvimento têm refletido a atuação de um Estado, ora centralizado, ora descentralizado, garantidor das condições de produção e reprodução dos interesses desses grupos privilegiados, apontando-se, porém, mudanças em períodos mais recentes, com a possibilidade de maior participação da sociedade nos processos decisórios.

O item seguinte trata então de fazer uma breve retomada dos contextos históricos das políticas urbanas e dos planos que antecederam a elaboração da primeira e segunda PNDUs.

\section{$\mathbf{I}$}

Um primeiro momento de planejamento institucionalizado ou governamental no Brasil nasce no começo do século XX, por volta das décadas de 1920 e 1930, na passagem da economia agrícola exportadora para o incipiente movimento de industrialização. O enfoque era econômico, e o "ambiente" progressista e modernista estimulava e criação e implementação de planos urbanísticos remodeladores das cidades, ou os projetos de cidades novas (Belo Horizonte e Goiânia são exemplos).

Monte-Mór destaca que já nas décadas de 30 e 40 os planejadores técnicos começaram ter uma visão da cidade a partir dos seus "problemas urbanos", buscando soluções técnicas e políticas para os problemas sociais que se avolumavam. Não 
somente a livre iniciativa privada, mas agora o Estado era um ator relevante nessas intervenções (MONTE-MÓR, 2008, p. 42). Os embates classistas, entre a nova burguesia industrial emergente e a classe operária que chegava a números cada vez mais expressivos nas cidades, também exigiam do Estado o papel de mediador desses conflitos.

Estado Novo varguista da década de 1940 assumiu então a posição dúbia de governo "populista" e patrocinador das condições de reprodução do mercado emergente, ao intermediar as relações de classe e garantir a estabilidade econômica necessária para o seu desenvolvimento. Nessa época, o urbanismo começa a assumir contornos de planejamento, inseridos no contexto político-administrativo como atividade normativa perene.

$\mathrm{Na}$ década seguinte (1950), o desenvolvimentismo do Estado concentrou esforços no incremento da industrialização interna, com capital externo, abrindo a economia nacional ao investimento de grandes grupos internacionais. Segundo Kohlsdorf (1976, p. 7), esse é o período do surgimento do planejamento econômico no Brasil, com o Estado assumindo e controlando de forma mais presente as relações econômicas, caracterizadas por uma responsabilidade crescente quanto à criação e distribuição das riquezas. Os planos desenvolvidos durante o Estado Novo representam, segundo a periodização proposta por Palazzo (citado por BOMFIM, 2007) (ver Quadro 1), um primeiro momento do planejamento nacional, caracterizado nesse período, por "políticas elitistas, clientelistas e populistas", como afirma Cintra (1978).

\section{Quadro 1 - Periodização dos planos governamentais no Brasil}

\begin{tabular}{|l|l|l|}
\hline PERIODO & PLANO & Estado Novo \\
\hline $1934-1945$ & Marcha para o Oeste e outros & $\begin{array}{l}\text { Governo Vargas, via DASP (Departamento } \\
\text { Administrativo do Serviço Público) }\end{array}$ \\
\hline $1946-1956$ & Plano Qüinqüenal, Plano de Obras & $\begin{array}{l}\text { Governo Juscelino Kubitschek e parceiros } \\
\text { internos (BNDE, CEPAL, FGV) e externos } \\
\text { (financiadores) }\end{array}$ \\
\hline $1956-1963$ & Plano de Metas & $\begin{array}{l}\text { Governo Goulart (Celso Furtado à frente como } \\
\text { economista) }\end{array}$ \\
\hline $1963-1965$ & Plano Trienal & Governo militar \\
\hline $1964-1966$ & Plano de Ação Econômica do Governo - PAEG & Governo militar \\
\hline $1968-1970$ & $\begin{array}{l}\text { Plano Estratégico de Desenvolvimento (Plano } \\
\text { de Integração Nacional PROTERRA, }\end{array}$ & \\
\hline 1970 & PROVALE, PRODOESTE, PRORRURAL, PIN & Governo militar \\
\hline $1972-1974$ & I Plano Nacional de Desenvolvimento (IPND) & Governo militar \\
\hline $1975-1979$ & II Plano Nacional de Desenvolvimento & Governo militar \\
\hline $1980-1985$ & III Plano Nacional de Desenvolvimento (cont.) & Governo de transição (abertura democrática) \\
\hline 1988 & Planos Diretores, Planos plurianuais & Governos democráticos \\
\hline
\end{tabular}

Fonte: PALAZZO, citado por BOMFIM (2007). Sistematização da autora. 
Bonfim (2007) destaca o momento mundial de ascensão desses planos nacionais, principalmente após a Segunda Guerra ${ }^{12}$ a partir dos planos do Estado novo no Brasil e, posteriormente, das políticas cepalinas ${ }^{13}$ para os países da América Latina. As políticas cepalinas preconizavam principalmente o desenvolvimento econômico dos países da América latina naquele período, visando o fortalecimento das relações econômicas entre os países latino-americanos e desses com os demais continentes.

Scherer (1995) explica que o pós-guerra desencadeou um momento de busca de alternativas de desenvolvimento social envolvendo Estado e economia de um modo diferente dos modelos até então vigentes, e esse momento coincidiu com o início do planejamento governamental no Brasil. Os planos setoriais em nível nacional para melhoria de desempenho, desenvolvidos segundo os modelos pré-existentes das economias centrais, deram lugar à prática do planejamento como técnica de governo e administração pública, com base em reflexões sobre a realidade latino-americana, encabeçadas principalmente pela escola cepalina, como referido anteriormente.

Segundo Kohlsdorf (1976), uma primeira mudança em relação ao planejamento nacional ocorreu a partir do Plano de Metas, de Kubitschek, do final da década de 50, dentro da segunda onda de planejamento no Brasil. Desenvolveu-se a partir disso uma idealização de planos nacionais de forma as integrar os diversos setores da economia brasileira, com idéias influenciadas por um corpo de técnicos e economistas que dominavam o pensamento econômico nacional nesse período. O Plano de Metas apresentava 30 metas centradas nos setores considerados estratégicos para o desenvolvimento nacional: energia, transporte, alimentos, indústrias de base, educação e no campo do "desenvolvimento urbano", a construção de Brasília, que representou o coroamento máximo do projeto urbanístico racional moderno nacional.

Na terceira fase desse planejamento, começava a se esboçar um planejamento comandado pela moderna burocracia estatal, reforçado pelo keynesianismo que

\footnotetext{
${ }^{12}$ Alguns despontes da força do planejamento estatal pelo mundo já se faziam presente no começo do século, como por exemplo, o New Deal do governo americano após o crack da bolsa em 1929 e posteriormente o Plano Marshall de recuperação das economias européias arrasadas pela guerra.

${ }^{13}$ A Comissão Econômica para a América Latina e o Caribe (CEPAL) foi criada em 25 de fevereiro de 1948, pelo Conselho Econômico e Social das Nações Unidas (ECOSOC), e tem sua sede em Santiago, Chile. A CEPAL é uma das cinco comissões econômicas regionais das Nações Unidas (ONU). Foi criada para monitorar as políticas direcionadas à promoção do desenvolvimento econômico da região latinoamericana, assessorar as ações encaminhadas para sua promoção e contribuir para reforçar as relações econômicas dos países da área, tanto entre si como com as demais nações do mundo. Posteriormente, seu trabalho ampliou-se para os países do Caribe e se incorporou o objetivo de promover o desenvolvimento social e sustentável.
} 
preconizava a intervenção do Estado na economia. No entanto, nas periferias capitalistas, como no caso do Brasil, esse "ar de modernidade" vinha carregado de conservadorismo, posto que a burocracia que estava à frente desse processo era composta pelas antigas oligarquias e elites que já comandavam o Estado anteriormente, podendo-se falar em uma "modernização conservadora" que mantinha certos padrões pré-existentes. Nesse período foi criado o Conselho de Desenvolvimento como órgão condutor do planejamento, que reunia técnicos, ministros, presidentes de órgãos e bancos, chefes de gabinetes, enfim, a "nova" burocracia estatal que seria responsável pela implementação do Plano, contando com novas instituições e órgãos como BNDE, Comissão Mista, CEPAL, etc. (ABREU, 1990).

Como motor desse planejamento estava a idéia defendida pela escola cepalina de promover a substituição de importações como forma de alavancar a industrialização dentro do nosso capitalismo tardio. No contexto de pós-guerra, essa substituição de importações promoveu uma dinâmica interna de acumulação que intensificou o intervencionismo estatal no patrocínio de ajustes das condições nacionais para o capital. A atuação do Estado sobre o urbano nesse período foi, como cunhou Celso Furtado (citado DÉAK, 2004), de "socialização das perdas e privatização dos lucros", com o Estado patrocinando grandes obras necessárias à reprodução do capitalismo e à organização espacial das regiões para instalação das indústrias e da mão-de-obra nas cidades.

Porém, segundo avalia Kohlsdorf (1976), nessa etapa ainda não se podia falar em uma preocupação real do Estado com o planejamento urbano. Mudanças na perspectiva puramente econômica do planejamento nacional se apresentaram somente no Plano Trienal, no governo militar, incluindo a perspectiva político-administrativa e social, mas com o plano seguinte, o PAEG (Plano de Ação Econômica do Governo) isso retrocedeu por um tempo.

A centralização levou o governo federal a institucionalizar oficialmente o planejamento por meio da criação de um ministério responsável pela implementação e execução do plano. Sucederam essas experiências o I e o II Plano Nacional de Desenvolvimento. É a partir desses planos que se apresenta uma preocupação maior em se tratar a questão urbana com mais atenção. 
Após os PNDs, a era dos planos nacionais de desenvolvimento exauriu-se juntamente com as crises política e econômica que se sucederam na década de oitenta. Mudanças significativas no planejamento nacional só se dariam a partir da redemocratização, da descentralização político-administrativa e de inovações apresentadas a partir da Constituição de 1988. Até esse período, pode-se dizer que o planejamento governamental priorizou diretrizes econômicas, e só posteriormente atentou para as novas demandas pelo processo de organização espacial das cidades e regiões.

Como já visto, a geopolítica foi a estratégia de planejamento territorial do Estado centralizador militar garantindo que a materialização das estratégias no espaço fosse "organizada" segundo a ordem vigente dos objetivos econômicos, visando atender os diversos interesses então em jogo, principalmente dos grupos políticos dominantes. Segundo Cintra (1978), na nova coalizão política militar, sedimentada na Escola Superior de Guerra, os líderes militares e civis debatiam os problemas nacionais e sobre eles definiam opiniões comuns, e em parcelas dos círculos tecno-burocráticos, espalhados por toda a máquina burocrática estatal, ou organizações privadas.

Pela Doutrina da Escola Superior de Guerra (ESG), o projeto político nacional se configurava em torno do tema da segurança. A base das diretrizes geopolíticas eram a política nacional, o poder nacional e os objetivos nacionais. O "poder nacional" seriam os meios econômicos, políticos, militares, sociais, geográficos e diplomáticos para garantir ou manter o poder interna e externamente de uma nação. Os "Objetivos Nacionais Permanentes" preconizados pela doutrina esguiana, eram: a democracia (?), a integração nacional, a integridade territorial e do patrimônio nacional, a paz social, progresso e soberania, e ainda, a independência política e defesa do sentido federativos, garantindo-se a autonomia municipal, o fortalecimento da estrutura econômica e a manutenção do Brasil em posição de destaque na América latina ${ }^{14}$.

Transferidas para o plano territorial, as estratégias geopolíticas esguianas, as características básicas do planejamento no período militar foram: (i) complementaridade tecnocrático-economicista e visão geopolítica militar do desenvolvimento nacional; (ii) desenvolvimento econômico-social revestido de caráter territorial; (iii) planejamento autoritário e centralizador; (iv) planejamento focado no

\footnotetext{
${ }^{14}$ Alguns desses objetivos são claramente questionáveis pela prática que foi aplicada no período, muito pelo lado do centralismo e do autoritarismo.
} 
território, com planos de integração nacional e desenvolvimento regional. Os planos estatais militares assumiram, portanto, um caráter pragmático de implementação desse ideário apoiado na geopolítica da ESG, que claramente se refletiram nos planos de desenvolvimento nacionais elaborados nesse período (BOMFIM, 2007, p.11).

É sob essa "tônica" que tem início a fase do planejamento de caráter efetivamente urbano, ou seja, para lidar com os problemas surgidos no Pós-II Guerra Mundial, e que claramente delinearam as políticas urbanas federais concebidas nesse contexto.

\section{II}

Já tendo falado anteriormente sobre o histórico dos planos nacionais, que tiveram um enfoque muito economicista, vale resgatar aqui um pouco da história dos antecedentes do planejamento urbano no Brasil, para se compreender melhor a trajetória que leva às bases referenciais e concepções nas políticas em estudo.

As primeiras preocupações quanto aos problemas urbanos no Brasil iniciaramse com um enfoque de "urbanismo", ou seja, o fato urbano era considerado sob aspectos quase que essencialmente físicos, por equipes de arquitetos ou engenheiros, de maneira pouco metódica. Segundo a autora, os planos surgiram como expressão dos princípios urbanísticos no final do séc. XIX, dentro de uma concepção urbana apenas como macro-arquitetura, com influência do racionalismo dos anos 30 de enfoque funcional da cidade (KOHLSDORF,1976).

Kohlsdorf (1976) relata ainda que o enfoque dado aos problemas urbanos pelas instituições públicas limitava-se, até a década de 60 , a uma "seção das Secretarias de Obras Públicas que, na maioria das vezes, encarregava seus engenheiros ou arquitetos da elaboração de um código de obras ou de projetos específicos de redes de infra-estrutura (abastecimento de água, canalizações de esgotos ou redes de distribuição de energia elétrica)". Inicialmente, na grande parte dos municípios brasileiros, estes serviços limitavam-se à sede do mesmo, sendo de natureza intra-urbana, não se estendendo às regiões mais periferias, rurais, ou mesmo vizinhas. 
De qualquer modo, para Monte-Mór (2008), as origens do desenvolvimento de planos urbanísticos no Brasil não fogem à regra do curso dos países periféricos, de "importação" das idéias e experiências dos países centrais. Um exemplo é o do urbanismo sanitarista que se desenvolveu na Europa e Estados Unidos no final do século XIX, dentro de um movimento de ações práticas e teóricas, tendo seqüencia no chamado urbanismo técnico e setorial, de influência francesa e americana (CAMPOS FILHO, 1999).

O urbanismo sanitarista do começo do século confundia-se com o planejamento urbano e suas ações, mas se caracterizavam por "códigos de regulamento urbanísticos quanto às edificações e 0 uso, à ocupação e ao parcelamento do solo, que equivaleriam aos atuais códigos de obras, que abrangem tanto as normas relativas às edificações, quanto às do parcelamento do solo e do seu uso, ou seja, o zoneamento" (CAMPOS FILHO, 1999, p. 6). Além do zoneamento, o projeto e a construção de cidades novas também foi outra prática bastante disseminada desde o final do século XIX.

No Brasil, a incorporação do planejamento urbano no governo se deu com o rápido processo de urbanização ocorrido no início do século $\mathrm{XX}$, onde os problemas urbanos se ampliam. Segundo Monte-Mór (2008), "as cidades brasileiras começavam a demandar ações técnicas e políticas para os problemas sociais e econômicos que se avolumavam".

$\mathrm{Na}$ busca das referências do planejamento urbano nacional, merecem destaque as experiências gaúchas com planos diretores da década de 1930, e a promoção de seminários e cursos sobre o planejamento das cidades, que geraram um movimento inicial de reflexão sobre a forma de lidar com o novo quadro urbano, esboçando rompimento com a idéia anterior para o processo contínuo de planejamento (MONTE-MÓR, 2008). "Desloca-se o problema urbano da pré-concepção ideológica formal do espaço, segundo uma análise funcional do organismo ou instrumento 'cidade', para uma visão da aglomeração urbana que demanda soluções técnicas do Estado, para ordenação do espaço em expansão, principalmente por meio de investimentos indutores e de legislação apropriada ao controle social” (Idem, p. 43).

Além da experiência gaúcha, foram destacadas pelo autor as experiências do grupo SAGMA, do Padre Lebret, uma versão brasileira do movimento francês 
"Economia e Humanismo", e do CEPEU (Centro de Pesquisa e Estudos Urbanísticos da Faculdade de Arquitetura e Urbanismo da USP), que agregaram à experiência francesa a norte-americana no desenvolvimento de planos com participação popular. Apesar da inovação desses métodos, muitos dos planos desenvolvidos acabaram sem implementação.

\section{III}

O "Seminário de Habitação e Reforma Urbana" ${ }^{15}$ realizado em 1963 no Hotel Quitandinha, em Petrópolis, reunindo arquitetos, planejadores, pesquisadores e agentes do poder público, foi um primeiro sinal de mudança na perspectiva do planejamento desenvolvido até então, e da política urbana, também inexistente até esse momento. Esse grupo defendia a necessidade de uma política mais abrangente e sistemática para os problemas urbanos (da qual a habitação deveria constituir programa estratégico, mas apenas parte do conjunto maior): "tal política deveria exprimir-se, seja num sistema de planejamento, seja num conjunto de leis e regulamentos atualizados, que substituíssem os documentos obsoletos relativos, e preenchessem os vazios que as novas necessidades tornaram evidentes nesse campo" (Cintra, 1978).

O tema da reforma urbana surge no contexto das proposições das "reformas de base" de João Goulart, antes do período militar (1964-984). Segundo Cintra (1978, p. 189), "de fato, durante a presidência de João Goulart o problema habitacional continuou sendo o ponto de partida para a questão. Já não só se reclamava um planejamento mais abrangente, mas também, reformas institucionais de longo alcance. Conseqüentemente ampliou-se a visão até então parcial do problema urbano (...). O tema reforma urbana passou a ocupar o centro do palco".

Esse processo foi interrompido pelo golpe militar de 1964, que interpôs outra visão, pautada na lógica militar. Segundo relata Cintra (1978, p. 203), a partir de então foi dada ênfase à organização hierárquica e definida com precisão, e aos cálculos estratégicos na política de governo. Nesse contexto é que começam as surgir o planos nacionais de desenvolvimento, a partir de estudos de diagnósticos realizados desde

\footnotetext{
${ }^{15}$ Apesar de não ter sido apontada uma fonte documental desse Seminário, os muitos relatos encontrados em diversas literaturas apontam esse evento como um marco para o movimento para a Reforma Urbana.
} 
1966 pelo Ministério do Planejamento sobre as áreas de saúde, previdência social, saneamento e educação.

Alguns dos planos destacavam a necessidade de medidas frente à constatação do crescimento intenso e desordenado das cidades brasileiras. A preocupação com o planejamento urbano, entretanto, decorria das situações econômicas problemáticas (desequilíbrios entre atividades econômicas e ocupação do solo urbano), reduzindo o planejamento urbano à visão da economia.

O Plano Decenal, por exemplo, de 1967, elaborado pelo IPEA, apontou bases para formulação de uma política nacional de desenvolvimento urbano, definindo as regiões-programa e os pólos de desenvolvimento. Monte-Mór (2008, p. 48) destaca o conteúdo desse Plano como abordando questões intra-urbanas, regionais e metropolitanas, considerando o autor que ele preconiza uma Política Nacional Urbana, como instrumento para alterar a estrutura de urbanização do país, com inspirações nas experiências francesa e americana. No entanto, as prioridades dadas ao "milagre econômico" fizeram com que prevalecesse o modelo centralizador de implementação das diretrizes econômicas, colocando o BNH (Banco Nacional de Habitação, criado em 1966) frontalmente contrário ao Plano Decenal e afinado com as políticas econômicas do governo.

A partir dessa experiência, pode-se dizer que se tem uma base referencial para se empreender uma política nacional de desenvolvimento urbano, buscando-se - pelo menos uma parte desses pensadores e formuladores, certamente não os militares superar a fase clientelista, particularista e distributiva a que estavam submetidas às políticas urbanas, principalmente as habitacionais, dos governos anteriores (CINTRA, 1978, p. 188) ${ }^{16}$

A outra tentativa de incorporação dos problemas urbanos no planejamento governamental, segundo esse autor, foi a inclusão de um capítulo sobre desenvolvimento regional e urbano no Programa de Metas e Bases para a Ação do Governo (MeBAG), de 1970, mas que acabou se limitando ao enfoque setorial e

\footnotetext{
${ }^{16} \mathrm{O}$ autor refere-se, por exemplo, às políticas habitacionais empreendidas desde os governos de Getúlio Vargas, de caráter extremamente populista, sem critérios de alocação, configurando-se o favor como uma prática de governo de barganha com os atores, organizações ou níveis de governo de interesse.
} 
pontual, sem uma preocupação de integração no nível do conjunto urbano, como relata Monte-Mór (2008).

O que se sucedeu a essas tentativas foi a elaboração da primeira política urbana nacional, dentro do II Plano Nacional de Desenvolvimento ${ }^{17}$. O chamado "Programa de Ação do Governo para o Desenvolvimento Urbano", segundo Monte-Mór, mudou o enfoque sobre o urbano em relação aos planos anteriores, partindo para uma tentativa de definição macro-espacial da política urbana nacional: "não mais se pretendeu montar um sistema a partir da ótica municipal, de baixo para cima, mas onde as grandes definições de investimento e planejamento serão tomadas autoritariamente, de cima para baixo, como de resto todo o sistema econômico e político montado no país" (MONTE-MÓR, 2008, p. 60).

Nesse contexto, como se verá na descrição da PNDU de 1975, o discurso era de que a centralização, o autoritarismo e a tecnocracia dos órgãos administrativos eram necessários à organização racional do espaço urbano, com investimento centralmente coordenados pelos diversos órgãos criados nos demais níveis para gerir esse processo. Afora os grandes planos setoriais em nível federal, delegava-se aos níveis inferiores, principalmente aos municípios, a elaboração de planos diretores, que acabaram sem ter uma força executiva e eficiente no atendimento aos problemas urbanos que se acumulavam no nível local (Serra, 1991).

O grande impacto do modelo de política urbana empreendida no período militar foram os altos investimentos em habitação, saneamento e infra-estrutura realizados pelo $\mathrm{BNH}$, que alcançaram proporções nunca antes vistas, em que pesem as críticas aos modelos de habitação produzidos, ao privilégio à classe média no uso dos recursos do FGTS, e da priorização do investimento em infra-estrutura também para as regiões e metrópoles mais desenvolvidas, alimentando o ciclo da desigualdade, exclusão e desequilíbrio do sistema urbano nacional, em fase de agravamento crescente.

Experimentou-se após a experiência da primeira PNDU uma atuação pouco sistemática de enfrentamento dos problemas urbanos e regionais no Brasil $^{18}$,

\footnotetext{
${ }^{17}$ Segundo Monte-Mór, o I PND não dedica parte especial ao desenvolvimento urbano e regional, apesar de considerar os aspectos espaciais regionais como integrantes fundamentais.

${ }^{18}$ Steinberger e Bruna (2001) afirmam que "desde 1985, com o advento da Nova República, deixou de existir um discurso oficial de política urbana nacional. Propostas subsidiárias para tal foram elaboradas 17 antes e depois da instalação do novo governo. Algumas até incluídas nos sucessivos planos nacionais
} 
resultando desse entendimento parcial e desarticulado da questão urbana, políticas de cunho setorial, a manutenção das políticas clientelísticas e direcionadas às classes privilegiadas e o desmonte do aparato institucional para o desenvolvimento da política urbana nacional. O planejamento urbano, da forma que vinha sendo elaborado, caiu em descrédito e na ineficácia mediante os problemas urbanos, regionais e metropolitanos em curso.

\section{IV}

Paralelamente à falência do modelo de política e planejamento do período militar, o movimento pela Reforma Urbana, iniciado na década de 1960 volta a ganhar novo fôlego com a abertura política e redemocratização após a "queda" da ditadura, sinalizando para uma mudança no entendimento da política urbana nacional.

Segundo Grazia di Grazia (2001) a questão urbana nos anos 70, dentro de um quadro de profundas desigualdades sociais, degradação ambiental e das condições de vida, surge a partir da expressão dos movimentos sociais urbanos e da institucionalização de um planejamento urbano racional e tecnocrata, conjuntura essa que permitiu, a partir a da sua negação, o desenho de condições básicas para 0 ressurgimento da bandeira pela Reforma Urbana.

Decorrente dessa mobilização dos movimentos comunitários, setoriais urbanos, intelectuais e acadêmicos, juntamente com os sindicatos é que se conseguiu, por meio de emenda popular, a inclusão do capítulo constitucional sobre a política urbana, os artigos, 182 e 183, na nova constituição de 1988. O primeiro tratou da função social da cidade e da propriedade urbana e o outro da usucapião da propriedade urbana.

No contexto da Constituição de 1988, o processo de planejamento retomou sua importância, assumindo natureza jurídica e maior formalização no processo de elaboração dos planos e políticas urbanas. O planejamento intra-urbano, como a ferramenta básica para a formulação e execução da política urbana nas cidades, passou a ser juridicamente regulamentado e definido em termos de competências dos diversos níveis federais após a nova Constituição 
Segundo SILVA (1997), "os planos urbanísticos passaram a ser aprovados por lei, assumindo características não só de um processo técnico e normativo, como também um procedimento jurídico dinâmico, que, tornando-se lei, configura uma articulação de diretrizes normativas de um plano e dá eficácia jurídica às regras concretas que ele contém".

Os planos diretores participativos, instrumentos básicos do novo modelo de política urbana adotado, obrigatório para os municípios acima de 20 mil habitantes, são os instrumentos que darão materialidade a essa normatização jurídica. O município como ente federativo teve que assumir um papel relevante na gestão e implementação da política urbana, concentrando grande parte das responsabilidades quanto às ações para melhoria da qualidade de vida nas cidades.

Como expresso na nova Carta Constitucional de 1988, a distribuição de competências de cada ente federado deu à União a responsabilidade de elaborar e executar planos nacionais e regionais de ordenação do território e de desenvolvimento econômico, bem como instituir diretrizes para 0 desenvolvimento urbano, principalmente nas áreas de saneamento, transportes e habitação.

Ficou a cargo da União o estabelecimento de diretrizes para o desenvolvimento urbano e sua responsabilidade coordenativa, ou mesmo executiva em algumas situações. A instituição de regiões metropolitanas, aglomerações urbanas e microrregiões, para integrar a organização, e o planejamento e a execução de funções públicas de interesse comum passa a ser responsabilidade dos Estados.

A aprovação do Estatuto da Cidade em 2001, que regulamentou o capítulo constitucional sobre a política urbana nacional, foi outro passo jurídico e normativo na regulamentação da Política Nacional de Desenvolvimento Urbano. O Estatuto estabeleceu os parâmetros e diretrizes da nova PNDU e, como já mencionado, ainda regulamentou instrumentos da política urbana para que o município pudesse intervir no processo de planejamento e gestão urbana e territorial.

A despeito de toda a "renovação conceitual", legal e institucional para o desenvolvimento da Política Urbana Nacional, a herança política do passado e as mudanças nos circuitos mundiais de produção, economia e comércio, e principalmente a "financeirização" da economia, são um desafio muito presente na elaboração dessa 
nova PNDU, porquanto afetam diretamente o processo de tomada de decisões, as relações capital, trabalho e Estado, e as "funções" das cidades e regiões nesse cenário.

Esse é o quadro, contado a partir do começo do século, que descreve sucintamente a trajetória do urbanismo, do planejamento estatal, dos planos urbanísticos e das políticas urbanas, tendo como foco o momento de concepção da primeira PNDU na década de 70, até a segunda PNDU, já em 2004. Isso posto, tem-se uma base para a apresentação descritiva das Políticas Nacionais de Desenvolvimento Urbano, doravante estudadas com maior aprofundamento.

\subsection{A PNDU de1975}

Considera-se na presente pesquisa como PNDU de $1975^{19}$, o capítulo 5 do Programa de Ação do Governo, dentro do II PND - cuja fonte de referência é o documento publicado pelo Ministério do Interior Conforme Steinberger e Bruna (2001, p. 44), o referido texto "Política de desenvolvimento urbano, do capítulo Desenvolvimento Urbano: Controle da Poluição e Preservação do Meio Ambiente" do II PND tem sido considerado o marco temporal da primeira política urbana nacional do Brasil, como referenciam Steinberger e Bruna:

"O item Política de desenvolvimento urbano, do capítulo Desenvolvimento Urbano: Controle da Poluição e Preservação do Meio Ambiente do II PND tem sido sagrado como marco temporal da primeira política urbana nacional do Brasil." (Steinberger e Bruna, 2001, p. 44)

\subsubsection{Processo de elaboração}

Um primeiro e importante fato a ser considerado é a natureza dessa primeira PNDU: uma política de desenvolvimento definida como uma resolução ministerial, como destaca Serra (1991), concebida e restrita ao âmbito de um ministério, o Ministério do Interior, quando o assunto "urbano" deveria envolver vários ministérios e ter força de lei.

\footnotetext{
${ }^{19}$ Essa primeira apresentação das políticas nacionais de desenvolvimento na pesquisa restringir-se-á ao escopo descritivo das mesmas, posto que as análises e comparações dar-se-ão no desenvolvimento dos capítulos posteriores. As descrições e transcrições são referentes ao Capítulo 5 "Política Nacional de Desenvolvimento Urbano" do documento descritivo do II Plano Nacional de Desenvolvimento Urbano"., com destaques por conta da autora.
} 
Considerando o contexto político ditatorial do período, o processo de elaboração da PNDU de 1975 foi conduzido de forma restrita a técnicos e especialistas em planejamento urbano e regional, num processo dito "de gabinete", conduzido unicamente pelo Ministério do Planejamento e Coordenação Geral como uma "resolução ministerial", e depois delegado para "implementação" à CNPU (Comissão Nacional de Programas Urbanos).

Era um documento normativo, indicativo de diretrizes para o planejamento urbano e intra-urbano, com inspiração européia, principalmente inglesa e francesa, segundo Souza (2004, p. 119). As influências estrangeiras eram um misto de comprehensive planning inglês, do land use americano, além do aménagement $d u$ territoire francês e sofreu influência do já longínquo racionalismo do movimento modernista (STEINBERGER E BRUNA, 2001).

No plano técnico e burocrático, o pensamento econômico e o geopolítico constituíam as "inspirações" centrais do discurso oficial, que se traduziam na busca da integração territorial, na segurança e soberania nacional, no pacto federativo, e principalmente, objetivavam o desenvolvimento econômico e social, o que se confirmava na função precípua da PNDU de desenvolver-se segundo os "Objetivos Nacionais" da ESG.

Apesar do discurso de integração nacional, pode se adiantar que prevaleceu uma ação muito setorizada do planejamento urbano, além de visão mecanicista da cidade como unidade de produção e consumo. A preocupação central colocada pelo governo para o planejador estava na minimização das diferenças regionais, tanto em termos demográficos, quanto em qualidade de vida, o que se traduzia na verdade na preocupação com o desenvolvimento econômico e industrial nacionais, como já visto (SOUZA, 2004).

\subsubsection{Pressupostos, objetivos e diretrizes}

\section{I}

A concepção da Política Nacional de Desenvolvimento Urbano de 1975 partia de uma "subordinação" à Política Nacional de Desenvolvimento Econômico e Social. As razões da PNDU, ou seja, seus pressupostos, objetivos e diretrizes deveriam alinhar-se 
à visão do II PND, pois era considera como "uma decorrência e uma condicionante deste, constituindo-se em um dos seus desdobramentos no plano espacial" (MINISTÉRIO DO INTERIOR, 1975).

No discurso oficial a importância que o Governo dava ao problema urbano se refletia na decisão de "conduzir o desenvolvimento de modo integrado e equilibrado" por meio da formulação de uma política urbana que refletisse, espacialmente, a estratégia global de crescimento e de transformação social. A PNDU devia, então, atender aos objetivos econômicos, sociais e de segurança nacional ${ }^{20}$, com intento maior de "promover a integração nacional e reduzir os desequilíbrios inter-regionais". Esses eram os dois eixos principais sobre os quais se assentavam as premissas da PNDU.

A PNDU partia também do reconhecimento da heterogeneidade contrastante do sistema urbano nacional, em termos de: (i) dimensão das unidades urbanas; (ii) dos padrões de suas distribuição espacial (iii) dos níveis de equipamento (iv) e das funções que desempenhavam. A partir disso, a PNDU deveria ser capaz de promover também "o fortalecimento e a melhor estruturação do sistema urbano do País, assim como de seus subsistemas regionais", reforçando-se mais uma vez a necessidade de adequação aos "grandes objetivos nacionais".

As diferentes tipologias urbanas deveriam ser atendidas pela PNDU de modo específico. Para as grandes cidades, deveria ser capaz de trazer melhor nível de qualidade de vida; para os núcleos dinâmicos, deveria ser capaz de promover o crescimento racionalmente ordenado; para os núcleos periféricos, trazer desenvolvimento econômico; e para áreas ainda de ocupação rarefeita, como a amazônica, dar prioridade às estratégias de ocupação. A PNDU partia do reconhecimento da metrópole e dos grandes centros urbanos como os portadores da capacidade de difusão da modernização e do desenvolvimento nacionais: "é na eficácia do desempenho das funções metropolitanas que se apóia, em grande parte, o desempenho da economia e a difusão dos impulsos de modernização".

A hipótese escolhida como eixo condutor da política foi a da "concentração regional com contenção das metrópoles nacionais e reforço das cidades de porte

\footnotetext{
${ }^{20}$ Esses objetivos foram definidos dentro da geopolítica da Escola Superior de Guerra.
} 
médio", ou, em outras palavras, o que chamaram de "desconcentração concentrada". "Essa hipótese adotava, em suas entrelinhas, um embasamento teórico pautado no equilíbrio do sistema de cidades, sustentando que, por meio desse, seria possível atingir uma qualidade de vida melhor" (STEINBERGER E BRUNA, 2001)

\section{II}

Os objetivos da PNDU dividiam-se em básicos, os seja, que determinariam a sua "razão de ser", e os específicos, que definem de modo mais peculiar as ações para consecução dos objetivos principais.

Os objetivos principais relatados no documento oficial eram de "estimular, fomentar e intensificar" políticas e ações que pudessem:

i. "Promover o fortalecimento e a melhor estruturação do sistema urbano nacional e dos subsistemas regionais, com vistas à:

a. redução dos equilíbrios existentes;

b. maior eficácia no desempenho das funções urbanas;

c. elevação dos padrões de urbanização e de qualidade da vida urbana;

ii. Racionalizar e disciplinar o uso do solo de forma a:

a. rentabilizar as múltiplas utilizações do espaço urbano" (MINISTÉRIO DO INTERIOR, 1975, p. 73).

A atenção dessa política voltava-se para a rede urbano-regional, no sentido de prover condições de seus potenciais econômicos e acomodar as demandas do mercado e da produção nas cidades, especificamente as metrópoles e cidades médias. Para isso, esses pólos deveriam ser equipados (via projeto definidos em Planos Diretores) com equipamentos e infra-estrutura, principalmente as cidades médias, e capacidade administrativa de gestão dos "serviços comuns" metropolitanos, a serem compartilhados entre os três níveis de governo.

Para as regiões mais "abaixo" na hierarquia do sistema urbano-regional (Norte e Nordeste), os incentivos eram para criação e implementação de planos de desenvolvimento urbano (com projetos de "urbanismo", saneamento) e consolidação de núcleos planejados na Amazônia; e no mais, elaboração de estudos de interesse comum ao desenvolvimento em colaborações com os demais níveis de governo e capacitação de pessoal técnico-administrativo, para formação de uma "massa crítica" sobre planejamento urbano. Assim estava literalmente escrito no texto oficial da PNDU, no item (viii): 
i. "Promover a elaboração de planos diretores para as áreas metropolitanas e projetos específicos de saneamento básico e ambiental, de transporte e de estrutura administrativa;

ii. Criar condições para implementação desses projetos e dos sistemas de administração de serviços comuns (das três esferas de poder) de peculiar interesse;

iii. Apoiar a elaboração de PDDU's (Planos Diretores de Desenvolvimento Urbano) (Norte e Nordeste) e projetos específicos de urbanismo, saneamento básico e saneamento ambiental;

iv. Estimular a consolidação dos núcleos urbanos planejados (principalmente na Amazônia);

v. Proporcionar meios para a implementação dos PDL (Plano Diretor Local) para capitais dos territórios;

vi. Patrocinar a elaboração de estudos e projetos de interesse e do desenvolvimento urbano em colaboração com governos estaduais e administrações municipais;

vii. Fomentar o treinamento de executivos das administrações municipais e estaduais (prefeitura, servidores etc.)

viii. Intensificar o aperfeiçoamento de profissionais de nível superior em cursos de pós-graduação e especialização em planejamento urbano (MINISTÉRIO DO INTERIOR, 1975, p. 74).

Pode-se dizer que de uma forma geral, o discurso que se apregoava na elaboração dessa política urbana parecia apoiar-se nas premissas:

- Planejamento urbano via planos diretores locais, metropolitanos e regionais;

- Interiorização, com composição de novos núcleos urbanos e incentivos a cidades médias;

- Parcerias intergovernamentais na implementação de planos e na elaboração de estudos;

- Capacitação de recursos humanos.

\section{III}

As estratégias e diretrizes da Política de Desenvolvimento Urbano estavam definidas de acordo com três níveis do espaço territorial: nacional regional; metropolitano e urbano-local (ou intra-urbano), que receberiam tratamentos diferenciados de prioridades segundo as estratégias e diretrizes nacionais. Além das estratégias e diretrizes nacionais, foram previstas estratégias e diretrizes regionais específicas para cada região, devido às grandes diferenças espaciais, econômicas e sociais que cada uma apresentava, e também diretrizes específicas para as recémcriadas RMs (regiões metropolitanas) e para o espaço intra-urbano.

Dada a decisão do Governo Federal de "conduzir o desenvolvimento de modo integrado e equilibrado" a política urbana deveria refletir, espacialmente, a estratégia global de "crescimento e transformação social". A PNDU deveria: (i) contribuir para a "acelerar a integração nacional e a redução das desigualdades inter e intra-regionais e 
para a ordenação e expansão do processo de ocupação produtiva; e (ii) promover a melhor estruturação do sistema urbano, com vistas à maior eficácia das funções exercidas pelas cidades..." (MINISTÉRIO DO INTERIOR, 1975, p. 75).

Para a estruturação do sistema urbano, dever-se-ia buscar a "razão de ser" de cada nível territorial, ou seja, a sua função/vocação dentro do sistema urbano. Nacionalmente, a estrutura urbana a ser "alcançada" deveria estar alinhada com os objetivos e programas de desenvolvimento nacional e regionais. Às metrópoles regionais cabia encontrar sua função no sistema em conjunto com os papéis a serem desempenhados pelas metrópoles nacionais, especialmente nas áreas de maior concentração populacional e econômica. Os pólos secundários ${ }^{21}$ eram considerados imprescindíveis_na estratégia de descentralização nacional e regional, principalmente em virtude de suas capacidades de aglomeração econômica, social ou política; e às cidades, cabia o reconhecimento de suas funções políticas, econômicas e sociais, para planejamento de suas "estruturas administrativas e configurações físico-urbanísticas".

Definido esse quadro geral de estratégias e diretrizes básicas, a outra etapa de organização da Política deveria se debruçar sobre as problemáticas regionais e definir estratégias e diretrizes regionais gerais e depois específicas para cada região ${ }^{22}$, em função de suas especificidades e estágio de urbanização característicos de cada macrorregião. Do ponto de vista de Bomfim, a estratégia de desenvolvimento urbano regional dentro da PNDU objetivava:

i."a desconcentração intra-regional do sistema urbano dominante da região sudeste, através principalmente do esforço prático de evitar o crescimento excessivo de São Paulo e do Rio de Janeiro;

ii.a ordenação do processo de desenvolvimento do sistema urbano da Região Sul, mediante a expansão ordenada das metrópoles regionais do sistema urbano e o fortalecimento dos núcleos urbanos de médio porte;

iii.a dinamização das bases econômicas do Nordeste e o reforço das atividades produtivas dos equipamentos sociais dos pólos urbanos industrializados;

iv.a promoção da urbanização nas áreas de ocupação recente ou não consolidada das regiões Norte e Centro-oeste;

v.e a organização do desenvolvimento das metrópoles e da região econômica de Brasília" (BOMFIM, 2007, p.319).

\footnotetext{
${ }^{21}$ Steinberger e Bruna (2001) levantam a hipótese de que o investimento nas cidades médias era o caminho para o equilíbrio do sistema urbano, e isso fica claro a partir da explicitação das estratégias regionais.

${ }^{22}$ Essas estratégias concentram o volume maior de "proposições" da PNDU, reforçando a importância que era dada à questão regional.
} 
As estratégias regionais específicas desdobravam-se em ações de "dinamização de funções urbanas...", "promoção da ocupação...", "controle e organização do processo...", "ordenar e ocupar...", "disciplinar a ocupação...", "coordenar investimentos..." etc. de acordo com as prioridades definidas para cada região.

O Mapa 1 mostra como essas categorias se concretizavam no mapeamento das ações por áreas de interesses específicos, transparecendo as preocupações em "conter" o afluxo populacional das regiões mais povoadas, "dinamizar" as regiões com potencial ainda pouco explorados, ocupar as regiões mais "inóspitas", e claro, a definição dos eixos de penetração para escoamento de produção, circulação de produtos, enfim, muitas ações tendo por base a "dinamização da economia", que era claramente o fito principal que motivava o planejamento das ações dentro dessa PNDU.

Mapa 1 - Mapa do desenvolvimento urbano na PNDU de 1975

II PLANO NECIONAL DE DESENVOLVIMENTO

POLITICA NACIONAL DE

DESENVOLVIMENTO URBANO

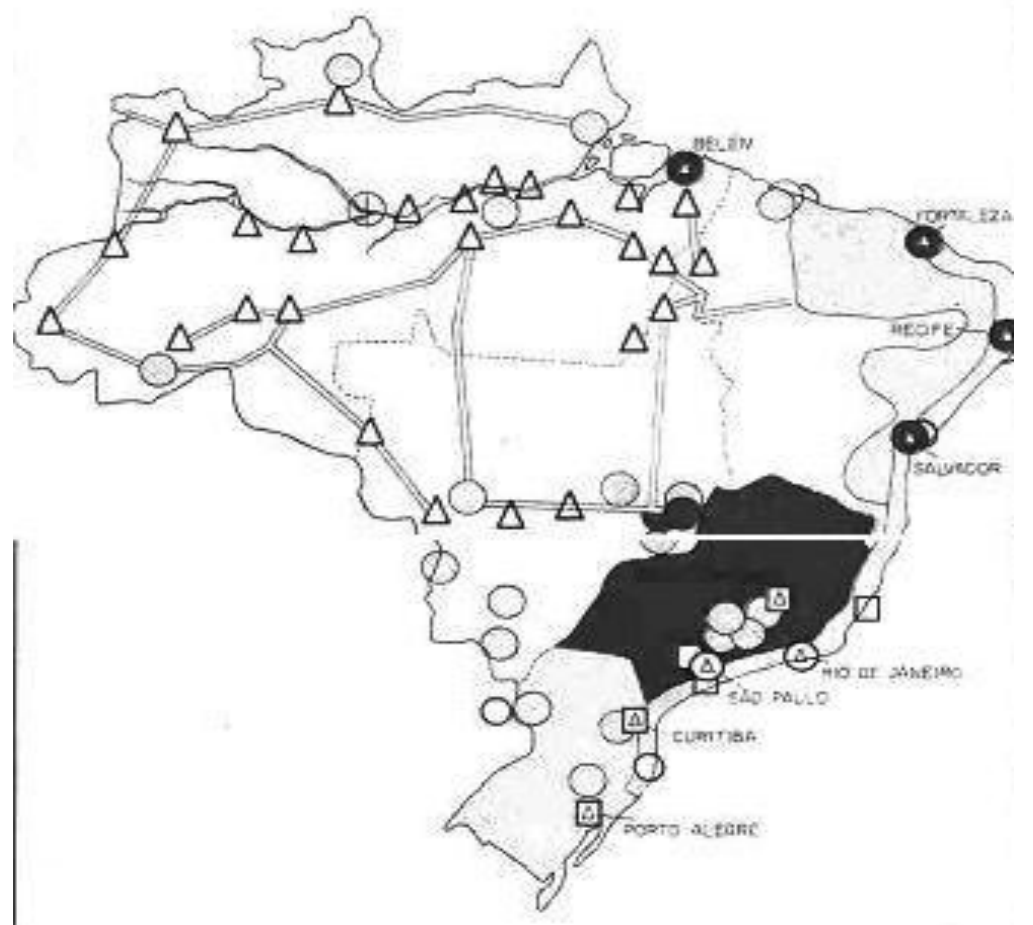
O AREA CE CONTEÇי
$\triangle$ NUCLEOS DE APOIO AO PROCESSO
$\square$ AREADE CONTROLE
$\triangle$ DE OCUPAÇÄO
- afeade disciflinae dinamizaçä́o
(1) REgICES DE TURISNO
Q hreade dinamizachio
AREAS DE PRCGRAMAS ESPECIAIS
EOXOS VIALRIOS DE PENETRAC̆ T̄O
REGICES METROPCUTANAS

Fonte: Ministério do Interior, 1975. 
As estratégias para as regiões metropolitanas partiam do pressuposto que a sua institucionalização (pelas Leis Complementares) deveria dar maior "racionalidade e eficácia ao planejamento e execução dos serviços comuns de interesse metropolitano". Com relação ao espaço intra-urbano, o Governo federal "reconhecia" a prerrogativa municipal de responsabilidade sobre o "planejamento intra-urbano", porém, colocava-se como um agente decisivo nessa "parceria intergovernamental", pela envergadura dos investimentos demandados pela urbanização acelerada e necessidade de coordenação na implementação das infra-estruturas urbanas (energia, transporte, comunicações, habitação, saneamento).

Essa "co-participação" decisiva se definia por: apoiar técnica e financeiramente o planejamento metropolitano e execução dos serviços comuns; alinhar a atuação federal às diretrizes de planejamento metropolitano e intra-urbano; e financiar os projetos prioritários de desenvolvimento urbano e metropolitano, de acordo com a PNDU.

\section{IV}

Para coordenação da PNDU, o Governo Federal criou a CNPU (Comissão Nacional de Regiões Metropolitanas e Políticas Públicas) para ser órgão responsável pelas ações em nível federal, com a missão de propor as diretrizes, estratégias e instrumentos da PNDU, bem como acompanhar e avaliar sua execução, com especial atenção sobre a implantação das regiões metropolitanas. À CNPU competia:

- "compatibilizar e adequar os instrumentos relativos à localização das funções industriais, pelo caráter altamente indutor que apresentam no processo de desenvolvimento urbano, tanto nos aspectos políticos, como econômicos e sociais;

- compatibilizar os mecanismos relativos à política financeira fiscal, que por sua origem e aplicação no meio urbano, influenciam a qualidade e nível de infra-estrutura econômica e social;

- desenvolver e aperfeiçoar os instrumentos relativos aos sistemas administrativos dos centros metropolitanos, bem como definir o seu crescimento adequado tendo em vista, também, as condições de lazer, recreação e segurança necessárias à vida social, tanto comum como individual às populações urbanas." (MINISTÉRIO DO INTERIOR, 1975, p. 77)

Na execução da PNDU, o Governo Federal deveria dispor dos mecanismos de coordenação, de ação normativa e de apoio financeiro, que se traduziam em criação de instrumentos legais, normativos e financeiros e políticas de financiamento, bem como transferências da União aos Estados e Municípios, como explicitado no documento. Os 
instrumentos legais e normativos referem-se a um conjunto de normas a serem elaboradas levando em conta as características próprias do sistema urbano nacional. Assim, previa-se a criação de instrumentos regulatórios de uso e ocupação do solo urbano (e também rural), bem como normas edilícias.:

- "regulamentação do uso do solo urbano;

- aprovação de códigos de obras e de loteamentos;

- desmembramentos realizados em áreas rurais;

- preservação da qualidade do meio-ambiente e do patrimônio histórico e paisagístico;

- regulamentação das desapropriações de terrenos urbanos;

- criação de novas regiões metropolitanas" (Idem, p. 78).

O governo federal dispunha de um forte aparato tecnocrático coordenado pelo MINTER (Ministério do Interior), que contava com órgãos como:

- IBGE (Instituto Brasileiro de Geografia e Estatística) e IPEA (Instituto de Pesquisa Econômica Aplicada), para suporte de informações e pesquisa;

- SERFHAU (Serviço Federal de Habitação e Urbanismo), para a coordenação do planejamento intra-urbano (local e municipal);

- BNH (Banco Nacional de Habitação), gestor dos fundos e investimentos, como o FNDU (Fundo Nacional de Desenvolvimento Urbano);

- SUDENE (do Nordeste) e a SUDAM (da Amazônia), como as superintendências de desenvolvimento regional

- DNOS (Departamento Nacional de Obras de Saneamento), a SEMA (Secretaria Especial de Meio Ambiente), como órgãos coordenadores das políticas setoriais;

E como instrumentos financeiros para provisão de recursos para financiamento de programas e projetos urbanos, contava-se com o:

- O programa FIPLAN (Programa de Financiamento para o Planejanento Urbano) e o FINEP para o financiamento dos planos de desenvolvimento urbano (mais para distritos e áreas industriais)

- Os Fundos de Desenvolvimento Urbano (da CEF - Caixa Econômica Federal, BNH - Banco Nacional de habitação, BB - Banco do Brasil, BNB - Banco do Nordeste, BASA - Banco da Amazônia S.A), para o apoio aos projetos urbanos

- O BNH para habitação, abastecimento de água e equipamentos comunitários;

- e com as transferências da União aos Estados e municípios.

Segundo Souza (2004), o BNH era de fato o órgão central na execução da política nacional de desenvolvimento urbano, movimentando um alto volume de recursos dos fundos urbanos, do FGTS e ainda da Caixa Econômica Federal . Na proposição original, a atuação do BNH deveria limitar-se ao campo da habitação, abastecimento de águas e equipamentos comunitários, mas este órgão foi 
paulatinamente aumentando seu campo de ação e controle sobre recursos, numa clara política de centralização da gestão dos recursos.

\section{V}

Em síntese, sobre a PNDU de 1975, Serra (1991) apresenta um quadro geral ressaltando os principais pontos que estruturaram o escopo dessa primeira Política Nacional de Desenvolvimento Urbano.

\section{POLITICA NACIONAL DE DESENVOLVIMENTO URBANO - PNDU}

OBJETIVOS

- Melhoria da qualidade de vida urbana

- Melhor distribuição espacial da população e das atividades produtivas

- Harmonização do sistema de cidades com prioridades e diretrizes regionais e setoriais

CATEGORIAS ESPACIAIS

- Área de expansão controlada

- Área de descompressão

- Área de dinamização

- Área com funções especiais

DIRETRIZES INTRA-URBANAS

- Melhorar a utilização do espaço urbano

- Prioridade para a habitação

- Melhorar os transportes urbanos

- Água e saneamento

- Meio ambiente - apoio a estados e municípios

- Patrimônio histórico e ambiental - preservação CENTROS URBANOS

- Metropolitanos - Programas de regiões metropolitanas

- Médio porte - Programa de capitais e cidade de porte médio

- Pequeno porte - Programa de cidades de pequeno porte

- Núcleos de apoio - Colonização, turismo e grandes projetos INSTRUMENTOS

- Institucionais - CNDU

- Legais

- Financeiros

- Técnicos

Fonte: SERRA (1991).

\subsubsection{Planos, programas e ações propostos}

Além dos Planos Diretores de Desenvolvimento Urbano (PDDU), planos metropolitanos e regionais, a implementação da PNDU se faria por meio também da implementação de vários programas, projetos e ações propostas dentro do "Programa de Ação do Governo para o Desenvolvimento Urbano". Os programas estavam divididos em setoriais, metropolitanos e de núcleos urbanos e regionais, e previstos 
para terem sua implementação coordenada pelos órgãos do Ministério do Interior. As áreas de abrangência dos programas eram: habitação, saneamento geral e básico, transportes urbanos, capacitação de recursos humanos, controle da poluição e preservação do meio ambiente.

O principal órgão gestor dos recursos para investimento na implementação da PNDU, o Banco Nacional de Habitação, além de boa parte de recursos próprios, deveria ter "contrapartida de entidades públicas e privadas, parcelas orçamentadas da União, transferências federais para Estados e Municípios, recursos provenientes do Fundo de Desenvolvimento Urbano (FDU) e do Fundo de Desenvolvimento de Programas Integrados (FDPI)" (MINISTÉRIO DO INTERIOR, 1975, p. 79). Segundo Serra:

"O Banco Nacional de Habitação (BNH), que já vinha sendo preparado para assumir encargos relativos ao desenvolvimento urbano, institui programas que abrangem a infra-estrutura (Plano Nacional de Saneamento-Planasa e Projeto Comunidade Urbana para Recuperação Acelerada-Cura), a implantação de novas comunidades urbanas (Projeto de Apoio ao Desenvolvimento dos Pólos Econômicos-Prodepo), o transporte de massa (Programa de Integração de Transportes UrbanosPiturb) e o planejamento urbano (Programa de Financiamento para o Saneamento-Finansa). São igualmente ligadas à questão da desconcentração urbana as propostas referentes ao fortalecimento dos centros de porte médio. Estas propostas deram origem ao 'Programa de Apoio às Capitais e Cidades de Porte Médio', do Conselho Nacional de Desenvolvimento Urbano (CNDU)" (Serra, 1991, p. 58).

No setor habitacional, o Plano Nacional de Habitação previa o investimento em recursos para construção de moradias para o "mercado popular", "econômico" e "médio superior". O PLANHAP (o Plano Nacional de Habitação Popular) contaria com aplicação de recursos das três esferas de governo dentro dos Fundos de Habitação popular, os FUNDHAPs e propunha a reestruturação das COHABs (Companhias de Habitação Estaduais). Essas companhias estaduais seriam os grandes pontos de articulação e implementação da PNDU na área de habitação.

O mercado "econômico" de habitações, que deveria equivaler à classe média baixa, receberia investimentos também sob a justificativa de haver terrenos com "adequada infra-estrutura, próximas de centros" - a localização e o preço da terra já faziam a segregação - cujos preços finais dos imóveis deveriam ser compatíveis com o nível de renda das famílias. O financiamento da habitação de alta renda se daria por meio do SBPE (Sistema Brasileiro de Poupança e Empréstimo), dos Institutos de Previdência e agentes privados, com o BNH entrando com taxas de juros mais altas 
que as de mercado para reinvestir nos mercados populares e econômicos. Ainda foram previsto programas de urbanização integrada de forma a atender os problemas surgidos com o crescimento acelerado das cidades de falta de infra-estrutura e equipamentos urbanos.

O PLANASA (Plano Nacional de Saneamento) estava para ser concluído ainda, em etapa de aperfeiçoamento dos mecanismos financeiros, administrativos, gerenciais, técnicos e de pesquisa. Estava embasado em três premissas principais, que era o abastecimento de água potável, serviços adequados de esgotos sanitários e serviços de esgotos simples. Ainda os PECON (Programas Estaduais de Controle de Poluição) previa medidas de controle de esgotamento sanitário e outro programa trabalharia no controle de enchentes e outras ações.

A SEMA (Secretaria de Meio Ambiente) definiu programas com a finalidade de conservação do meio-ambiente e uso racional dos recursos naturais, com repercussões na área urbana. É dessa época também o PROJETO RONDON, em parceria com as universidades no apoio ao treinamento técnico de pessoal das prefeituras, portanto, com impactos no nível local-municipal.

Para os Programas das Regiões Metropolitanas foram estabelecidas diretrizes básicas gerais de atuação que deveriam ser apoiadas em ações que visariam a:

- $\quad$ implantar e estruturar os sistemas de administração metropolitana;

- compatibilizar os orçamentos, investimentos, programas e projetos dos três níveis de governo, em cada região metropolitana;

- adequar as condições de infra-estrutura, saneamento básico, habitação, transportes e sistemas viários e comunicações, como suporte do fortalecimento da base econômica;

- $\quad$ adequar legislações vigente, em decorrência da institucionalização das regiões metropolitanas;

- $\quad$ prevenir e minimizar a deterioração da qualidade de vida,

- otimizar a distribuição espacial dos equipamentos urbanos em função da definição do uso do solo;

- $\quad$ elaborar Planos Diretores e estudos metropolitanos;

- criar condições para que os serviços comuns de natureza metropolitana pudessem ser tratadas em nível distinto dos serviços municipais, estaduais e federais;

- capacitar recursos humanos em problemas de planejamento metropolitano (MINISTÉRIO DO INTERIOR, 1975, p. 88).

Para cada região também foi proposto um programa específico, e destacam-se por exemplo a criação do órgão técnico para a Grande São Paulo, o GEGRAN e o 
Plano Metropolitano de Desenvolvimento Integrado desta Região, a criação do Grupo do Grupo Executivo da Região Metropolitana (GERM) de Porto Alegre e o desenvolvimento de planos preliminares (Estado e Municípios) e PMDI e planos setoriais.

Pode-se considerar uma programação bem abrangente em termos de suporte à recém-criada instância metropolitana de gestão. Mas, como se viu ao longo dos anos, houve alguns avanços, mas na sua maioria essas ações ainda não conseguiram ser efetivadas de modo sistemático e articulado entre os membros das regiões metropolitanas, sendo hoje um dos principais pontos de debate e ação da nova PNDU de 2004.

As ações intra-urbanas foram postas no escopo dos Programas de Núcleos Urbanos, definindo-se ações específicas por regiões, onde se destacaram os trabalhos de apoio às prefeituras, a estruturação de novos núcleos urbanos, atenção às migrações internas, etc., e a criação dos Sistemas Estaduais de Desenvolvimento Urbano-local, de capacitação do setor público para o enfrentamento dos problemas decorrentes da urbanização, com o objetivo de "descentralizar as funções do Governo Federal e contribuir com o desenvolvimento dessas ações nos demais níveis de governo".

\section{II}

Essas foram as principais proposta de programas, planos e ações decorrentes dos objetivos e diretrizes da PNDU - então denominado "discurso" do governo federal. Não obstante os resultados implementados nessas cidades, percebe-se que os "discursos" e propostas apontam para a busca de um equilíbrio entre os interesses voltados ao capital industrial e ao fomento das regiões mais atrativas, e o enfrentamento dos reais problemas urbanos.

Para Souza (2004), essa é uma questão básica de partida sobre a I PNDU: contradição entre o discurso da política desenvolvimento urbano e da política de desenvolvimento econômico. A primeira preconizava a integração nacional, a descentralização de investimentos, a redução dos desequilíbrios regionais, mas o II PND discursava - e punha em ação - políticas de concentração de investimentos, que 
acabavam por fomentar a desigualdade regional e o crescimento dos problemas intraurbanos. As diretrizes da PNDU claramente se chocavam com as interesses do II PND.

Por isso, os pensadores urbanos responsáveis por elaborar essas diretrizes nacionais (incluindo-se a autora), distinguiam uma política urbana de fato, representada pelas ações e investimentos que já se executavam nas cidades, de uma política urbana de direito, onde procuravam estabelecer essa visão por meio de normas, ações, diretrizes, programas e projetos tornados explícitos e públicos.

De fato, o planejamento urbano proposto - entendido como as propostas de planos diretores, metropolitanos, regionais, quando existentes - aconteceria sem muita repercussão ou impacto efetivo nos problemas urbanos, posto que na maioria das vezes os planos elaborados não passaram de relatórios técnicos recheados de diagnósticos e ações propositivas mais próximos de instrumentos de retórica que de ação efetiva.

Essa herança, de um planejamento urbano, de ações centralizadas pelo governo federal, de concentração populacional nas metrópoles, de aumento do desequilíbrio regional, de discrepância entre o discurso proposto e a ação implementada dentro de uma política federal, foi parte do legado deixado para reflexão e ação da próxima política federal.

\subsection{A PNDU de 2004}

$\mathbf{I}$

Considera-se nesse trabalho como PNDU 2004, o processo conduzido pelo Ministério das Cidades, a partir de 2004, utilizando-se como fonte de referência as publicações "Cadernos MCidades", especialmente o $N^{\circ} 1$, que trata da Política Nacional de Desenvolvimento Urbano. No entanto, a política de desenvolvimento urbano, tem sua efetiva base legal na Constituição Federal de 1988, inserida no "Capítulo II - Política Urbana", do "Título VII - Da Ordem Econômica e Financeira", definida no Artigo 182, nos seguintes termos:

"Art. 182. A política de desenvolvimento urbano, executada pelo poder público municipal, conforme diretrizes gerais fixadas em lei, tem por 
objetivo ordenar o pleno desenvolvimento das funções sociais da cidade e garantir o bem-estar de seus habitantes" (BRASIL, 1988).

A complementação desse Artigo Constitucional é a Lei 10.157/2001, o Estatuto da Cidade, que "Regulamenta os artigos. 182 e 183 da Constituição Federal, estabelece diretrizes gerais da política urbana e dá outras providências" (ESTATUTO DA CIDADE, 2001). O Artigo $2^{\circ}$ dessa lei estabelece os objetivos e diretrizes gerais que devem nortear a Política Urbana. Tendo em vista que esses objetivos e diretrizes são as premissas para elaboração da PNDU, justifica-se a transcrição integral desse Artigo (com destaques em negrito da autora) para não se perderem conteúdos importantes para posterior análise

“Art. 2 A política urbana tem por objetivo ordenar 0 pleno desenvolvimento das funções sociais da cidade e da propriedade urbana, mediante as seguintes diretrizes gerais:

I - garantia do direito a cidades sustentáveis, entendido como o direito à terra urbana, à moradia, ao saneamento ambiental, à infra-estrutura urbana, ao transporte e aos serviços públicos, ao trabalho e ao lazer, para as presentes e futuras gerações;

II - gestão democrática por meio da participação da população e de associações representativas dos vários segmentos da comunidade na formulação, execução e acompanhamento de planos, programas e projetos de desenvolvimento urbano;

III - cooperação entre os governos, a iniciativa privada e os demais setores da sociedade no processo de urbanização, em atendimento ao interesse social;

IV - planejamento do desenvolvimento das cidades, da distribuição espacial da população e das atividades econômicas do Município e do território sob sua área de influência, de modo a evitar e corrigir as distorções do crescimento urbano e seus efeitos negativos sobre o meio ambiente;

$\mathrm{V}$ - oferta de equipamentos urbanos e comunitários, transporte e serviços públicos adequados aos interesses e necessidades da população e às características locais;

$\mathrm{VI}$ - ordenação e controle do uso do solo, de forma a evitar:

a) a utilização inadequada dos imóveis urbanos;

b) a proximidade de usos incompatíveis ou inconvenientes;

c) o parcelamento do solo, a edificação ou o uso excessivos ou inadequados em relação à infra-estrutura urbana;

d) a instalação de empreendimentos ou atividades que possam funcionar como pólos geradores de tráfego, sem a previsão da infra-estrutura correspondente;

e) a retenção especulativa de imóvel urbano, que resulte na sua subutilização ou não utilização;

f) a deterioração das áreas urbanizadas;

g) a poluição e a degradação ambiental;

VII - integração e complementaridade entre as atividades urbanas e rurais, tendo em vista o desenvolvimento sócio-econômico do Município e do território sob sua área de influência;

VIII - adoção de padrões de produção e consumo de bens e serviços e de expansão urbana compatíveis com os limites da 
sustentabilidade ambiental, social e econômica do Município e do território sob sua área de influência;

IX - justa distribuição dos benefícios e ônus decorrentes do processo de urbanização;

$X$ - adequação dos instrumentos de política econômica, tributária e financeira e dos gastos públicos aos objetivos do desenvolvimento urbano, de modo a privilegiar os investimentos geradores de bem-estar geral e a fruição dos bens pelos diferentes segmentos sociais;

XI - recuperação dos investimentos do Poder Público de que tenha resultado a valorização de imóveis urbanos;

XII - proteção, preservação e recuperação do meio ambiente natural e construído, do patrimônio cultural, histórico, artístico, paisagístico e arqueológico;

XIII - audiência do Poder Público municipal e da população interessada nos processos de implantação de empreendimentos ou atividades com efeitos potencialmente negativos sobre o meio ambiente natural ou construído, o conforto ou a segurança da população;

XIV - regularização fundiária e urbanização de áreas ocupadas por população de baixa renda mediante o estabelecimento de normas especiais de urbanização, uso e ocupação do solo e edificação, consideradas a situação socioeconômica da população e as normas ambientais;

$X V$ - simplificação da legislação de parcelamento, uso e ocupação do solo e das normas edilícias, com vistas a permitir a redução dos custos e o aumento da oferta dos lotes e unidades habitacionais;

$\mathrm{XVI}$ - isonomia de condições para os agentes públicos e privados na promoção de empreendimentos e atividades relativos ao processo de urbanização, atendido o interesse social.

A determinação da função social da cidade e da propriedade urbana, certamente é o elemento fundador dessa nova concepção de políticas e planejamento urbano expressos nos fundamentos do Estatuto, e que passam a incorporar uma visão do desenvolvimento urbano que tem na cidade o seu lócus principal de ação, reforçado pelo "municipalismo" expresso na carta constitucional de 1988, também chamada "Constituição Cidadã".

Como base para a PNDU, destacam-se os princípios da gestão democrática com participação popular e a cooperação federativa nos processos de elaboração, implementação e avaliação das políticas e planejamento urbano, o que se desdobrará no lema da nova PNDU, "pactuação federativa democrática".

O desenvolvimento urbano deve levar em conta o crescimento populacional e o desenvolvimento econômico do município, observando os possíveis impactos que essa combinação pode ter na ocupação do território municipal e suas "franjas" urbanas, acompanhado de adequada provisão de infra-estrutura de transporte e equipamentos urbanos. 
O controle do uso e ocupação do solo urbano deve evitar as distorções históricas de zoneamento inadequado, ou ocupação à revelia de qualquer zoneamento, tanto pela especulação imobiliária, quanto pela desvalorização de áreas urbanizadas, ou pelos impactos de localização de determinados equipamentos. O princípio da justa distribuição de valorização urbana, bem como a aplicação equilibrada dos instrumentos urbanísticos para investimentos na cidade devem ser observados. A isonomia de condições entre agentes públicos e privados em empreendimentos urbanos devem também atender os interesses sociais.

Também no intuito de corrigir distorções do processo de desenvolvimento urbano dos últimos anos, para as áreas ocupadas por população de baixa renda a adequação de instrumentos de regularização fundiária e simplificação da legislação de uso e ocupação do solo e normas de edificação pretendem amenizar os passivos dos processos em curso.

Como parte também da regulamentação da Política de Desenvolvimento Urbano Nacional, o Estatuto também define o que compete à União nesse processo:

“Art. 3ํ Compete à União, entre outras atribuições de interesse da política urbana:

I - legislar sobre normas gerais de direito urbanístico;

II - legislar sobre normas para a cooperação entre a União, os Estados, o Distrito Federal e os Municípios em relação à política urbana, tendo em vista o equilíbrio do desenvolvimento e do bem-estar em âmbito nacional;

III - promover, por iniciativa própria e em conjunto com os Estados, o Distrito Federal e os Municípios, programas de construção de moradias e a melhoria das condições habitacionais e de saneamento básico;

IV - instituir diretrizes para o desenvolvimento urbano, inclusive habitação, saneamento básico e transportes urbanos;

$\mathrm{V}$ - elaborar e executar planos nacionais e regionais de ordenação do território e de desenvolvimento econômico e social." (ESTATUTO DA CIDADE, 2001).

É papel da União legislar em matéria de direito urbanístico (concorrentemente com os demais entes da federação, como estabelece o Art. 23 da CF) e da cooperação entre os três entes da federação para a política urbana, uma vez que o Artigo 23, além de dar as competências, também define que "Lei complementar fixará normas para a cooperação entre a União e os Estados, o Distrito Federal e os Municípios, tendo em 
vista o equilíbrio do desenvolvimento e do bem-estar em âmbito nacional" (BRASIL, 1988).

Em cooperação devem também ser promovidas iniciativas nas áreas de habitação e saneamento, bem como definir diretrizes para o desenvolvimento urbano nessas áreas, incluindo-se transporte. Por fim, o escopo da Política de Desenvolvimento Urbano a ser elaborada pela União deve prever a elaboração e execução de planos nacionais e regionais de ordenação territorial, no que concorre também com Estados, que detém também o poder de instituir e legislar sobre "regiões metropolitanas, aglomerações urbanas e microrregiões, constituídas por agrupamentos de Municípios limítrofes, para integrar a organização, o planejamento e a execução de funções públicas de interesse comum" (BRASIL, 1988) ${ }^{23}$.

Além da inclusão do capítulo constitucional da política urbana nacional em 1988, e da aprovação do Estatuto da Cidade em 2001, a criação do Ministério das Cidades em 2003 completa o ciclo de mudanças na estruturação legal e institucional que criariam o "ambiente" para proposição de uma nova PNDU.

"O Ministério das Cidades foi estruturado levando em consideração a reunião das áreas mais relevantes (do ponto de vista econômico e social) e estratégicas (sustentabilidade ambiental e inclusão social) do desenvolvimento urbano. Foram criadas quatro Secretarias Nacionais: Habitação, Saneamento Ambiental, Mobilidade e transporte urbano e Programas Urbana. Nessa estrutura, a Caixa Econômica Federal passou a ser a gestora e operadora dos recursos para o financiamento das políticas urbanas, em parceria com BNDES, principalmente na área de saneamento e transportes" (MINISTÉRIO DAS CIDADES, 2004a, p. 13).

Com sua estrutura definida, o Ministério das Cidades deu início à construção da Política Nacional de Desenvolvimento Urbano - PNDU, buscando por meio da "ação democrática, descentralizada e com participação popular", coordenar e integrar investimentos e ações focadas nos quatro setores urbanos (habitação, saneamento, transportes, e questão fundiária), agregando diversos segmentos sociais, esferas públicas e três poderes.

Assim, a estratégia para elaboração dessa Política foi de proporcionar uma discussão pública sobre temas do desenvolvimento urbano por meio de Conferências, partindo da instância de poder mais próxima do cidadão, o Município, depois seguindo

\footnotetext{
${ }^{23}$ Cf. Artigo 25, parágrafo 30 da CF de 1988.
} 
na hierarquia federal pelos Estados, até se consolidar a discussão em um amplo debate na primeira Conferência Nacional, realizada ainda em 2003, de onde saíram as primeiras proposições da PNDU, até serem consolidadas no documento oficial lançado em 2004, o qual é a base referencial dessa pesquisa.

Como resultado inicial desse movimento foram elaboradas as propostas de políticas setoriais de habitação, saneamento, transporte e mobilidade urbana, trânsito, planejamento territorial e a PNDU e foi criado o Conselho das Cidades, como instância de debates e negociação, de composição mista, para coordenação do processo de elaboração da nova PNDU.

Os princípios, objetivos e diretrizes da nova PNDU foram definidos então após as discussões da primeira Conferência Nacional das Cidades, em 2003, organizada pelo Ministério das Cidades, com ampla base de participação social. Como visto na sistemática do processo, as conferências municipais e estaduais levantaram propostas para discussão a serem levadas para o encontro nacional. Com a participação de diversos atores dos movimentos sociais, universidades e órgãos de classe, foram definidas as políticas setoriais que deveriam ser contempladas pela nova PNDU (habitação e política fundiária, saneamento ambiental, transporte e mobilidade urbana e planejamento territorial urbano).

\subsubsection{Princípios, objetivos e diretrizes}

\section{I}

O "marco lógico", ou que se poderia chamar de argumentos de partida, da nova PNDU de 2004, se apóia na idéia de que:

\footnotetext{
"a crise urbana exige uma política nacional orientadora e coordenadora de esforços, planos, ações e investimento dos vários níveis de governo e, também, dos legislativos, do judiciário, do setor privado e da sociedade civil. O que se busca é a equidade social, maior eficiência administrativa, ampliação da cidadania, sustentabilidade ambiental e resposta aos direitos das populações vulneráveis" (MINISTÉRIO DAS CIDADES, 2004a, p.7).
}

A justificativa é de que diante da necessidade de ordenar os processos urbanos em curso, direcionando e fomentando o desenvolvimento das cidades, a elaboração da nova Política Nacional de Desenvolvimento Urbano, conduzida pelo 
Ministério das Cidades, representa uma tentativa do governo federal em intervir, direcionar ou articular nacionalmente, entre governos e entre a sociedade, as políticas e ações a serem implementadas no ordenamento do território nacional e nas cidades, as ações intra-urbanas.

A idéia é de que a nova proposta de PNDU sirva como um "eixo norteador" para as ações dos poderes públicos, tendo como alicerce para a definição de políticas um "aparato institucional estável e reestruturador do urbano no País", objetivando incrementar a capacidade do Estado de formulador e gestor das políticas públicas, por meio de uma abordagem integrada das políticas setoriais, e perseguindo a construção de uma cooperação intergovernamental (pacto federativo) para elaboração e implementação da Política Nacional de Desenvolvimento Urbano, com efetiva participação democrática.

As proposições da PNDU, além da sua base técnica, ministerial e governamental ${ }^{24}$, procuram basear-se na realidade urbana a partir das reivindicações de quem vive a crise urbana, como também de quem teoriza sobre ela, e até por quem se beneficia de suas distorções. Poder-se ia dizer que é uma tentativa de construção de baixo pra cima, não de cima para baixo com anteriormente, onde o conhecimento acumulado associa-se à experiência vivida para as proposições realistas e que de fato causem algum impacto na melhoria da qualidade de vida urbana. apesar da estrutura governamental que a suporta,

\section{II}

Os princípios da nova PNDU baseiam fundamentalmente nos princípios expressos no Estatuto das Cidades de "direito à cidade", combinados com o princípio básico constitucional de "função social da cidade e da propriedade urbana".

\section{PRINCíPIOS}

- Direito à cidade;

- Moradia digna;

- Saneamento ambiental público;

- Transporte público;

- Função social da cidade e da propriedade;

- Gestão democrática e controle social;

- Inclusão social e redução das desigualdades;

\footnotetext{
${ }^{24}$ Como diz o próprio texto introdutório da PNDU, "é importante lembrar o compromisso do governo Lula com o Plano Plurianual 2004-2007 do Governo Federal, o Projeto Brasil em Três Tempos, formulado pelo Núcleo Estratégico da Presidência da República, e principalmente, as Metas do Milênio da Organização das Nações Unidas"
} 
- Sustentabilidade financeira e sócio-ambiental da política urbana;

- Combate à discriminação de grupos sociais e étnico-raciais;

- Combate à segregação urbana;

- Diversidade sócio-espacial

O direito à cidade é entendido como "direito à moradia digna, à terra urbanizada, ao saneamento ambiental, ao trânsito seguro, à mobilidade urbana, à infraestrutura e aos serviços e equipamentos urbanos de qualidade, além de meios de geração de renda e acesso à educação, saúde, informação, cultura, esporte, lazer, segurança pública, trabalho e participação" (MINISTÉRIO DAS CIDADES, 2004a, p. 77).

O princípio da função social da cidade e da propriedade urbana busca garantir a "prevalência do interesse comum sobre o direito individual de propriedade, contemplando aspectos sociais, ambientais, econômicos (de inclusão social) e a implantação combinada com os instrumentos do Estatuto da Cidade" (Ibidem). Com isso, a política de desenvolvimento urbana é colocada em um patamar de atendimento ao interesse coletivo no que dize respeito à propriedade urbana, superando, pelo menos em discurso, a prevalência dos interesses privados, calcados fortemente na função econômica (capitalista e elitista) da propriedade.

Nesse sentido, os princípios da inclusão social e da redução das desigualdades visam atender a população de baixa renda historicamente excluída dos "ganhos" do processo de desenvolvimento. Por isso o combate à segregação urbana também tem por base a redução da desigualdade histórica de ocupação do espaço, seja interurbana, intra-urbanas ou regionais, baseada também no princípio da acessibilidade à cidade e suas diversas funções - como transporte público e mobilidade, saneamento, lazer, moradia digna - como também garantia de direitos a uma cidadania ativa, por meio gestão democrática e controle social, com participação nos processos decisórios, e monitoramente da política urbana.

Pó último, o princípio da sustentabilidade financeira e sócio-ambiental da política urbana visa tanto à garantia de recursos para investimentos nos programas $\mathrm{e}$ ações da política urbana, com a participação dos três níveis de governo, bem como a proficuidade desses investimentos, elevando a eficiência dos gastos públicos em moradia, urbanização e serviços públicos urbanos, metropolitanos e regionais. 


\section{III}

Como produtos das discussões foram definidos os marcos diretivos da política urbana. Segundo o anexo do Caderno MCidades no 1, essas definições ficaram assim explicitadas em linhas gerais:

\section{DIRETRIZES}

- Políticas nacionais - formular, implementar e avaliar a PNDU e as políticas setoriais, com pacto federativo e participação, respeitando os princípios da universalidade, equidade, sustentabilidade, integralidade e gestão pública;

- Política urbana, social e de desenvolvimento - articular as políticas intersetorialmente (saúde, educação, emprego etc);

- Estrutura institucional - implementar o aparato institucional para a efetivação das decisões, com participação e descentralização;

- Participação social - promover um sistema de conferências para viabilizar a participação social na definição, execução, acompanhamento da política urbana de forma continuada;

- Políticas de desenvolvimento e capacitação técnico institucional - capacitação profissional e modernização do aparato institucional e normativo

- Diversidade urbana, regional e cultural - desenvolver programas e ações respeitando as especificidades, vocações e potencialidades de cada região, promovendo a redução das desigualdades regionais;

- Políticas abrangentes e massivas - para o enfrentamento de grandes problemas urbanos como déficit habitacional, regularização fundiária;

- Redes de cidades mais equilibradas - estruturar uma rede de cidades mais equilibradas sócio-economicamente e do ponto de vista das desigualdades regionais, a fim de promover a desconcentração e a descentralização do desenvolvimento urbano.

As principais diretrizes da Política Urbana Nacional em suma propõem: a constituição de cidades sustentáveis (provimento de terra, moradia, saneamento, serviços para os cidadãos) e democráticas (participação da sociedade nos processos de planejamento, definição de programas e projetos); a função social da propriedade urbana; a utilização de instrumentos de regulação de uso e ocupação do solo (IPTU progressivo, outorga onerosa, direito de superfície etc.), e da instituição do plano diretor como instrumento básico da política de expansão urbana; e, um elemento considerado fundamental para o pacto federativo, a cooperação entre os vários níveis de governo na implementação dessas políticas. 


\section{IV}

Os objetivos da PNDU definidos no processo de discussão têm como base o enfrentamento dos principais déficits urbanos, em termos de habitação e saneamento e passivos ambientais, a "renovação" do planejamento e da gestão urbana e territorial, tendo em vista a aplicação dos instrumentos do Estatuto da Cidade e a inclusão de novos parceiros na implementação dos programas; e os demais objetivos contemplam os princípios e diretrizes da gestão democrática e participativa, e provisão das melhoria gerais de condições de vida principalmente das populações vulneráveis e minorias.

As linhas gerais dos objetivos inicialmente definidos assim se expressam:

\section{OBJETIVOS}

- Redução do déficit habitacional - implementadas de forma ampla, com parcerias dos três governos, visando o atendimento a populações sem renda ou até 3 salários mínimos, com projetos tecnicamente adequados, em áreas urbanizadas;

- Acesso universal ao saneamento ambiental - saneamento de áreas de baixa renda em assentamentos precários, área de proteção ambiental; saneamento entendido em sentido amplo, por abastecimento, coleta de esgoto e disposição de resíduos sólidos, prevenção à poluição ambiental, visual e sonora;

- Geração integrada e sustentável da política de saneamento melhoria geral nos serviços de água, esgoto, resíduos sólidos, educação ambiental

- Mobilidade urbana com segurança - priorização do transporte coletivo, de automóveis não motorizados e dos pedestres

- Qualidade ambiental urbana - atenção às áreas ambientalmente mais vulneráveis

- Planejamento e gestão territorial - melhoria do planejamento e da gestão territorial de forma integrada, com visão de longo prazo e observando os instrumentos para a função social da propriedade urbana

- Diversificação de agentes promotores e financeiros - inclusão de novos parceiros, como cooperativas, associações comunitárias na implementação de políticas, programas e projetos de desenvolvimento urbano, habitação e gestão ambiental

- Estatuto da cidade - regulamentação do Estatuto e aplicação de seus instrumentos de política urbana, com ampla participação e melhoria na gestão e no controle do uso do solo na perspectiva de cumprimento da função social de cidade e da propriedade;

- Democratização do acesso à informação - criação de sistemas de informação acessíveis aos cidadãos, de forma a permitir o monitoramento das ações do poder público, de gastos, projetos etc;

- Geração de emprego, trabalho e renda - integração de ações de política urbana com ações de geração de emprego trabalho e renda, visando a inclusão social e aproveitamento das potencialidades regionais. 


\section{V}

Essas proposições iniciais da PNDU visam o enfrentamento de problemas mais intra-urbanos ${ }^{25}$ do que regionais, como era destaque em 1975, nas áreas de habitação, saneamento, transporte, gestão, capacitação, emprego, que devem desdobrar-se em políticas, programas e ações concretas.

O texto transparece uma visão de desenvolvimento urbano que tem no seu seu centro mais o indivíduo em si, ou seja, o espaço visto com suporte não só das relações sociais, mas da sociedade (como um coletivo de cidadão) e sua condição de vida na cidade. Abandona-se um entendimento de espaço como mero suporte de relações materiais na sua função de base para a produção, para um entendimento de que isso é apenas parte de um processo integral em várias dimensões (econômica, social, política, ambiental), que deve redundar em melhoria efetiva de qualidade de vida.

Por isso a PNDU toma como foco a cidade, mas não exclui de suas proposições as questões metropolitanas e regional, porque é nas grandes concentrações urbanas, metropolitanas e regionais, e suas assimetrias de desenvolvimento, que se encontram as origens e as conseqüências de grande parte dos problemas urbanos ${ }^{26}$ : "Repensar o desenvolvimento urbano e regional brasileiro implica em elaborar um projeto de médio e longo prazo que tenha como meta a redução das desigualdades regionais e sociais, um melhor ordenamento do território e uma visão de estratégia geopolítica que inclua nossa articulação com os países vizinhos" (MINISTÉRIO DAS CIDADES, 2004a, p. 33).

\footnotetext{
${ }^{25}$ A a questão regional aqui tangenciada recebe o destaque na Política Nacional de Desenvolvimento Regional (PNDR) em desenvolvimento pelo Ministério de Integração Regional, além de uma Política Nacional de Ordenamento Territorial (PNOT) e de Planos Estratégicos para o desenvolvimento das regiões.

26 "O crescimento da população e o rápido processo de urbanização implicaram no aumento da rede urbana, em geral, e das grandes cidades, em particular. Ao mesmo tempo houve rápido crescimento do tamanho das cidades, tendo o número de cidades com população acima de 50 mil habitantes subido de 38 em 1950 para 124, em 1970; e 409 em 2000, sendo 202 com população superior a 100 mil habitantes (mapas 1 e 2). Como muitas dessas cidades têm suas áreas urbanas contíguas a outras, amplia-se o tamanho das concentrações urbanas. Nesse sentido, existem hoje, no Brasil, 16 aglomerações urbanas com mais de 1 milhão de habitantes cada, lideradas pelas megametrópoles de São Paulo e Rio de Janeiro, mas seguidas por várias outras. Tal concentração populacional, sem o correspondente crescimento da oferta de infra-estrutura física (moradias, saneamento, transporte público), social (educação, saúde, lazer), emprego e renda, leva parte da população a viver em condições precárias, em favelas ou outras formas de assentamento onde prolifera a miséria, a degradação humana e o crime organizado" (MINISTERIO DAS CIDADES, 2004a, p. 34).
} 
Coloca-se a sociedade na condição de ator político relevante na construção desse processo, e também ressalta a responsabilidade dos três níveis de governo, na busca do "pacto federativo". Por isso, a PNDU é uma política ainda em construção, mas que pelo processo de discussão e proposições e resoluções encaminhadas e reconhecidas pelo poder público com questões que já têm sido incorporadas nas ações do Ministério das Cidades e de suas Secretarias.

As proposições da Política Urbana nacional têm sido constantemente revistas e ampliadas a cada nova discussão, com os textos básicos propositivos se aperfeiçoando e incorporando novos debates ou acentuando a importância de questões já contempladas. $\mathrm{Na} 2^{\text {a }}$ Conferência das Cidades, em linhas gerais a PNDU já apresentava os seguintes objetivos e princípios (com destaques da autora, e com inovações em itálico):

1) Estabelecer um projeto nacional que promova o desenvolvimento social, econômico e ambiental, o combate à desigualdade social, racial, de gênero, e regional. A meta é uma ocupação menos desigual do território brasileiro, com maior integração do espaço nacional, principalmente a partir do reconhecimento da diversidade e do papel das cidades como elementos essenciais para o desenvolvimento regional e do país.

2) Estabelecer diretrizes para o desenvolvimento urbano, integrando habitação, saneamento ambiental, transporte e mobilidade, baseadas nas deliberações da $1^{\text {a }}$ e $2^{\underline{a}}$ Conferência Nacional das Cidades e do Conselho das Cidades, considerando o Estatuto da Cidade (Lei 10.257/01) e o Artigo 21 da Constituição.

3) Conter a definição de urbano, rural, cidade, distritos, microrregiões, aglomerados urbanos, regiões metropolitanas e regiões integradas de desenvolvimento. Deve incluir, ainda, qualquer outro conceito que seja necessário para a correta interpretação da legislação federal, estadual e municipal.

4) Estabelecer diretrizes e prioridades para a cooperação, a coordenação e a articulação de ações intergovernamentais na área do Desenvolvimento Urbano, em particular nas matérias de competência comum entre União, estados e municípios.

5) Garantir a participação da população e de associações representativas dos vários segmentos da comunidade na formulação, execução e acompanhamento de planos, programas e projetos de desenvolvimento urbano.

6) Afirmar que os investimentos públicos em desenvolvimento urbano são de responsabilidade dos três entes federados - União, estados, Distrito Federal e municípios e devem ser aplicados para o enfrentamento das desigualdades sociais e territoriais, para a distribuição de renda e o crescimento econômico com justiça social.

7) Propor orientações para que estados e municípios formulem políticas, programas, planos e processos de seleção de projetos utilizando sistemas de informações e indicadores de livre acesso, para permitir uma análise clara da realidade social e urbana. E que também possibilitem avaliar o impacto das políticas e dos investimentos em desenvolvimento urbano, reconhecendo a exclusão territorial de contingentes populacionais, que não possuem pleno acesso a bens e serviços urbanos. 
8) Estabelecer diretrizes para a integração de políticas, planos e programas setoriais que abrangem o Desenvolvimento Urbano, bem como a sua articulação com políticas sociais, ambientais, econômicas, industriais e de infra-estrutura.

9) Definir diretrizes e prazos para a elaboração do Plano Nacional de Desenvolvimento Urbano, estabelecendo:

a) O levantamento de necessidades imediatas e futuras da população e a definição de prioridades de curto, médio e longo prazo.

b) As condições institucionais necessárias para o planejamento e a implementação de programas, projetos e ações no campo do desenvolvimento urbano, o que implica manter órgãos e quadros técnicos capacitados com estruturas físicas e apoio logístico que viabilizem uma gestão profissional e ilibada dos recursos públicos.

c) Uma agenda comum entre a União, estados e municípios para o desenvolvimento urbano" (MINISTÉRIO DAS CIDADES, 2006).

Observa-se no avanço das discussões a preocupação em se construir um projeto nacional de desenvolvimento urbano, com a integração das políticas, planos e programas setoriais, mas partindo-se das cidades como elemento estruturante do desenvolvimento regional e territorial. Para isso, propõe-se a preparação de uma base institucional e de cooperação entre os diversos entes, o pacto federativo, com o estabelecimento de uma agenda comum, garantindo-se também a continuidade da participação social no processo de desenvolvimento urbano, tomando como base o Estatuto da Cidade.

Apesar das desconfianças que sempre cercam um discurso governamental, o que pode legitimar o processo de construção da PNDU é a busca da superação, primeiramente, da sua negação enquanto política, que por muito tempo esteve ausente da agenda do governo federal, exceto pela experiência de 1975, como visto anteriormente, mas também a busca de uma "pactuação federativa e democrática", que também a difere do processo anterior, e não apenas como forma de garantir a perenidade desse processo contínuo de construção, mas também como foram de reunir condições estruturais e institucionais de superação - ou pelo menos, enfrentamento e minoração - dos passivos sociais, econômicos, políticos e ambientais dos processos de desenvolvimento urbano das últimas décadas.

\subsubsection{A sistemática de construção da nova PNDU: a busca da pactuação federativa democrática}


O contexto para elaboração das diretrizes da PNDU de 2004 foi de abertura política, descentralização administrativa e democratização. Diferentemente do processo empreendido em 1975, o processo de elaboração da política nacional de desenvolvimento teve início em 2003, com participação de representantes dos diversos setores da sociedade, bem como a colaboração dos diversos entes federados, e não se encerrou em uma resolução ministerial, mas tem se consubstanciado como um processo contínuo (até quando?), e uma agenda aberta a propostas dos mais diversos segmentos.

Para viabilizar esse debate, a sistemática de elaboração da PNDU foi estruturada a partir da realização de "conferências" primeiramente no nível municipal, sobre uma pauta pré-definida, para posterior discussão em encontro estadual e depois a participação dos "delegados" eleitos nessas conferências na Conferência Nacional, de onde resultaram proposições e resoluções para avaliação e incorporação na PNDU. A Figura 1 mostra esse esquema.



Figura 1 - Esquema de elaboração das proposições da PNDU de 2004.

Para gestão desse processo propôs-se a criação do Sistema Nacional de Desenvolvimento Urbano, que conjugue a liderança do Ministério das Cidades com as propostas da sociedade, expressas nas diretrizes e resoluções do Conselho das Cidades nas Conferências das Cidades, instancias e fóruns legítimos de debates e encaminhamentos da política de desenvolvimento urbano, traduzindo um processo de 
construção de políticas urbanas que congrega diversos setores da sociedade com o poder público, na tentativa de atender demandas diretas e concretas na formulação e implementação das políticas urbanas e dos planos diretores municipais.

O sistema, apoiado na formação de Conselhos e Fóruns, como organismos de fiscalização e debates, e a realização de Conferências, como instâncias de deliberações e proposições, se estruturou da seguinte forma:

- Conferência Nacional das Cidades

- $\quad$ Conselho Nacional das Cidades

- $\quad$ Conferência Estadual das Cidades e Distrito Federal

- $\quad$ Conselho Estadual das Cidades e Distrito Federal

- Conferência Municipal da Cidade

- Conselho Municipal da Cidade (integrando os Conselhos de Habitação, de Desenvolvimento Urbano e outros);

- $\quad$ Conferência Regional das Cidades (facultativo)

- $\quad$ Conselhos Regionais das Cidades (facultativo)

- Fórum de Integração Setorial, nos três níveis de governo com foco no desenvolvimento Urbano

- $\quad$ Fundo de Desenvolvimento Urbano, nos três níveis de governo.

- Fóruns Especiais na esfera Municipal/Regional" (MINISTÉRIO DAS CIDADES, 2008).

\section{III}

O Conselho das Cidades, criado em 2004, como já mencionado, é o principal fórum de deliberação e proposições da PNDU. O Decreto $n^{\circ}$ 5.031, de 2 de abril de 2004 dispõe sobre a composição, estruturação, competências e funcionamento do Conselho das Cidades e o define como "órgão colegiado de natureza deliberativa e consultiva, integrante da estrutura do Ministério das Cidades, que tem por finalidade estudar e propor diretrizes para a formulação e implementação da PNDU, bem como acompanhar a sua execução.

O Conselho das Cidades delibera acerca das mais diversas matérias relativas à PNDU e às ações e programas desenvolvidos pelo Ministério das Cidades por meio de suas resoluções, como decorrência do debate político e técnico realizado pelos conselheiros. Tem no total 34 resoluções homologadas. As resoluções podem ser: "recomendadas: relativas aos atos de outras unidades administrativas das esferas do Poder Público e entidades da sociedade civil; normativas: resoluções reservadas à regulamentação e normatização dos atos do ConCidades; ou administrativas: 
concernentes aos atos administrativos necessários à gestão do ConCidades" (MINISTÉRIO DAS CIDADES, 2006).

Em levantamento realizado por Maricato e Santos Jr. (2007) sobre a atuação do Conselho das Cidades entre 2004 e 2005 mostra a relevância da atuação do Conselho das Cidades por meios de suas deliberações, tendo quase $70 \%$ delas sido implementadas ou em implementação.

Tabela 1 - Balanço das Resoluções Emitidas pelo Conselho das Cidades de 2004-2005

\begin{tabular}{|l|c|c|c|c|}
\hline \multicolumn{5}{|c|}{ Deliberações Tomadas pelo Conselho das Cidades - 2004-2005 } \\
\hline Temática & Total & Implementadas & $\begin{array}{l}\text { Em } \\
\text { implementação }\end{array}$ & Sem resultados \\
\hline $\begin{array}{l}\text { Dinâmica de Funcionamento do } \\
\text { Conselho das Cidades e das } \\
\text { Conferências das Cidades }\end{array}$ & 7 & 5 & 1 & 1 \\
\hline Habitação & 5 & 4 & 1 & 0 \\
\hline Saneamento Ambiental & 7 & 4 & 1 & 2 \\
\hline Transporte e Mobilidade Urbana & $\mathbf{5}$ & 1 & 0 & 4 \\
\hline Planejamento Territorial Urbano & $\mathbf{5}$ & 2 & 2 & 4 \\
\hline $\begin{array}{l}\text { Política Econômica, Orçamento Geral da } \\
\text { União e Questões Federativas }\end{array}$ & $\mathbf{1 2}$ & 7 & 5 & 12 \\
\hline Totais & 41 & 23 & 5 & \\
\hline
\end{tabular}

Fonte: Tabulação produzida por Maricato e Santos Jr (2007) (adaptado pela autora) a partir do balanço produzido pelo Ministério das Cidades e das resoluções publicadas no Diário Oficial da União, com base nas resoluções aprovadas nas oito reuniões realizadas entre abril de 2004 até fevereiro de 2006. Observações: Na análise das resoluções, utilizando-se os seguintes critérios:

(i) Implementada: decisões que foram cumpridas pelos órgãos competentes, e produziram resultados efetivos ou parciais, conforme a resolução aprovada no Conselho das Cidades;

(ii) Em implementação: refere-se àquelas resoluções onde

as medidas estão em fase de implementação e que sua efetividade ainda não pode ser ainda plenamente avaliada;

(iii) Sem resultados: resoluções que não foram implementadas pelos órgãos governamentais responsáveis ou que, quando implementadas, não produziram resultados efetivos.

\section{Gráfico 1 - Balanço das Resoluções Emitidas pelo Conselho das Cidades de 2004-2005}

Deliberações Tomadas pelo Conselho das Cidades - 2004-2005

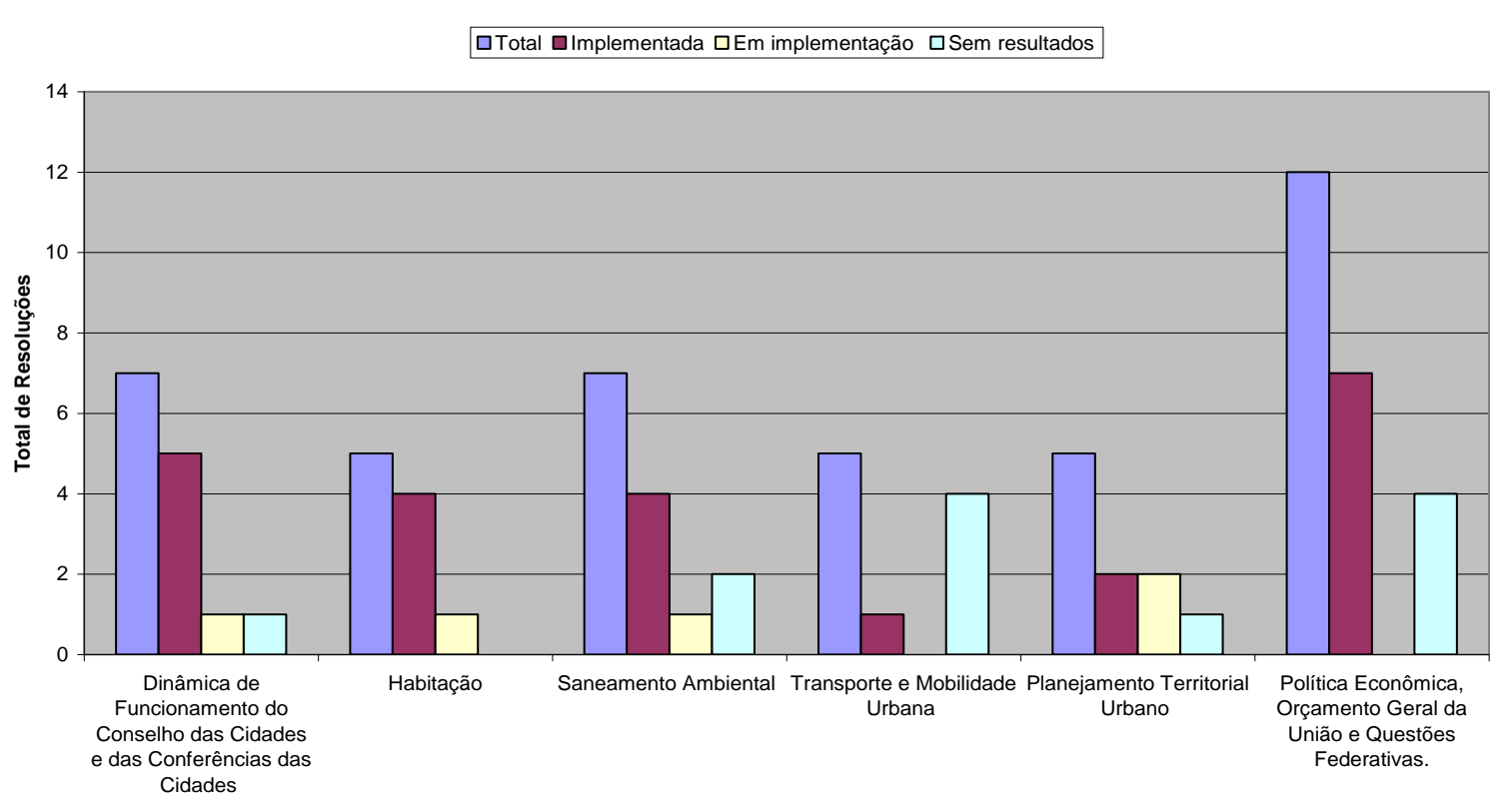


Fonte: Maricato e Santos Jr. (2007). Gráfico elaborado pela autora.

Além da PNDU, o Conselho também tem função de fazer proposições em matéria de legislação urbanística, em espacial o Estatuto das Cidades, de fomento da cooperação governamental e participação social, estimular a criação de sistemas de indicadores para avaliação e monitoramento do desenvolvimento urbano, e ainda promover estudos, debates e pesquisas sobre os resultados dos programas do Ministério das Cidades ${ }^{27}$.

"Tem se tornado um importante instrumento de gestão democrática da Política Nacional de Desenvolvimento Urbano - PNDU, viabilizando o debate em torno da política urbana de forma contínua, respeitando a autonomia e as especificidades dos segmentos que o compõem, como uma verdadeira instância de negociação em que os atores sociais participam do processo de tomada de decisão sobre as políticas executadas pelo Ministério das Cidades, nas áreas de habitação, saneamento ambiental, transporte e mobilidade urbana e planejamento territorial, por meio da articulação e negociação política, ação propositiva e qualidade técnica de debates" ${ }^{28}$.

A composição do ConCidades busca observar uma proporcionalidade entre poder público e sociedade e é constituído atualmente por 86 titulares - 49 representantes de segmentos da sociedade civil e 37 dos poderes públicos federal, estadual e municipal - além de 86 suplentes, com mandato de dois anos. A composição do ConCidades inclui além de representantes do poder público federal (ministérios e CEF, no total de 14), representantes do poder público estadual (6), o

\footnotetext{
${ }^{27}$ Segundo o Decreto são competências específicas do Conselho das Cidades: I - propor diretrizes, instrumentos, normas e prioridades da política nacional de desenvolvimento urbano; II - acompanhar e avaliar a implementação da política nacional de desenvolvimento urbano, em especial as políticas de habitação, de saneamento ambiental, de transportes e de mobilidade urbana, e recomendar as providências necessárias ao cumprimento de seus objetivos; III - propor a edição de normas gerais de direito urbanístico e manifestar-se sobre propostas de alteração da legislação pertinente; IV - emitir orientações e recomendações sobre a aplicação da Lei no $\mathbf{1 0 . 2 5 7}$, de 2001 , e dos demais atos normativos relacionados ao desenvolvimento urbano; $V$ - promover a cooperação entre os governos da União, dos Estados, do Distrito Federal e dos Municípios e a sociedade civil na formulação e execução da política nacional de desenvolvimento urbano; VI - promover, em parceria com organismos governamentais e não-governamentais, nacionais e internacionais, a identificação de sistemas de indicadores, no sentido de estabelecer metas e procedimentos com base nesses indicadores, para monitorar a aplicação das atividades relacionadas com o desenvolvimento urbano; VII - estimular ações que visem propiciar a geração, apropriação e utilização de conhecimentos científicos, tecnológicos, gerenciais e organizativos pelas populações das áreas urbanas; VIII - promover a realização de estudos, debates e pesquisas sobre a aplicação e os resultados estratégicos alcançados pelos programas e projetos desenvolvidos pelo Ministério das Cidades; IX - estimular a ampliação e o aperfeiçoamento dos mecanismos de participação e controle social, por intermédio de rede nacional de órgãos colegiados estaduais, regionais e municipais, visando fortalecer o desenvolvimento urbano sustentável; $X$ - propor as diretrizes para a distribuição regional e setorial do orçamento do Ministério das Cidades; e XI - aprovar seu regimento interno e decidir sobre as alterações propostas por seus membros.
}

${ }^{28}$ Ministério das Cidades (www.cidades.gov.br) Destaques da pesquisadora. 
poder público municipal (10), do movimento popular (19), trabalhadores (7), empresários (7), entidades profissionais, acadêmicas e de pesquisa (5) e ONG's (3), contando ainda com observadores representantes dos governos estaduais (9), que possuírem conselho das cidades, em sua respectiva unidade da federação (MINISTÉRIO DAS CIDADES, 2008).

Gráfico 2 - Composição do Conselho das Cidades: proporcionalidade de segmentos

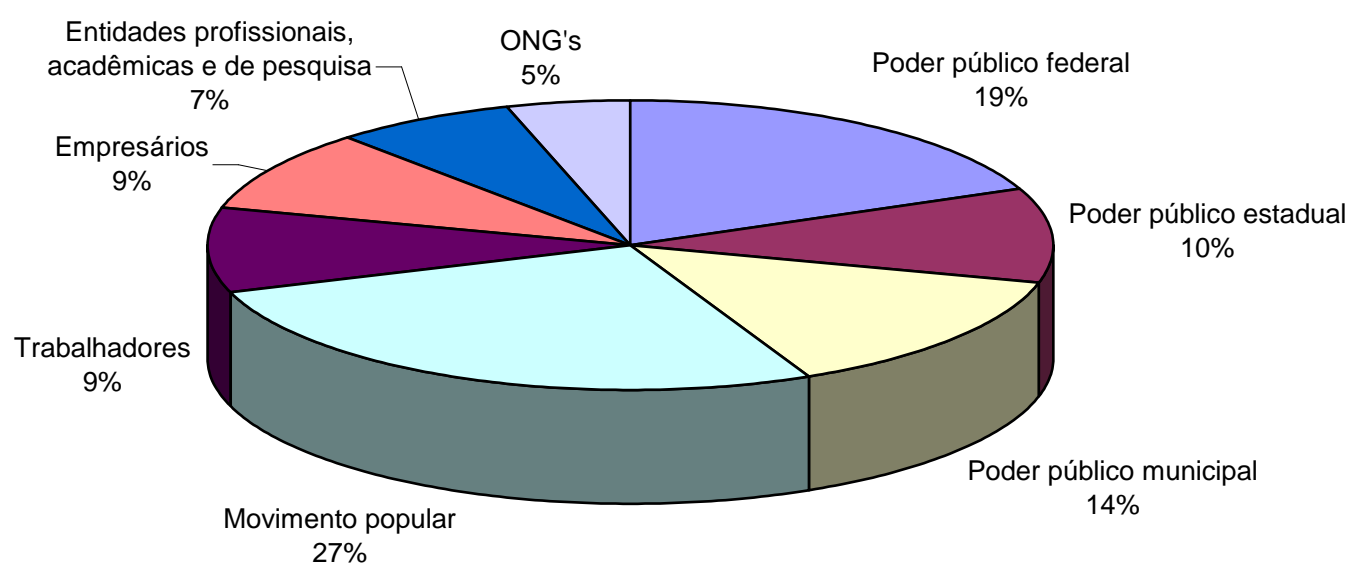

O Conselho é composto ainda por Comitês Executivos nas áreas estruturantes do Ministério das Cidades, Habitação, Saneamento Ambiental, Trânsito, Transporte e Mobilidade Urbana, e Planejamento Territorial Urbano, coordenados pelos respectivos Secretários de cada área.

Os Conselhos Estaduais não são obrigatórios, mas o Ministério das Cidades recomenda sua criação, para "garantir a estruturação mínima para que possa ser constituído o Sistema Nacional de Desenvolvimento Urbano, com articulação das instâncias de participação social entre as três esferas de governo", em que devem observar a proporcionalidade de $60 \%$ de representantes do poder público e $40 \%$ da sociedade.

No processo de elaboração da PNDU, o Conselho das Cidades tem exercido um papel fundamental na articulação e negociação entre os atores sociais e os representantes dos entes federados, viabilizando a democratização do processo de 
tomada de decisões a agregação de valor técnico, qualidade e sensibilização no atendimento às necessidades da sociedade. ${ }^{29}$

Delibera acerca das mais diversas matérias relativas à Política Nacional de Desenvolvimento Urbano - PNDU e às ações e programas desenvolvidos pelo Ministério das Cidades por meio de suas resoluções, fruto do debate político e técnico realizado pelos conselheiros. Nessa experiência, a equipe do Ministério afirma que uma das principais lições aprendidas é que "a democracia muda de qualidade quando o Poder Público se une à experiência acumulada da sociedade civil organizada e potencializa a sua participação na elaboração e execução dos programas e das políticas públicas".

De fato é marcante no contexto nacional, principalmente pelo período ditatorial vivido anteriormente, a abertura dada por um ministério federal à participação popular no processo de tomada de decisões. Como exposto pelo próprio Ministério "a estrutura do MCidades constitui hoje um paradigma, não só em território brasileiro, mas como em toda a América Latina. O movimento social formado por profissionais, lideranças sindicais e sociais, ONGs, intelectuais, pesquisadores e professores universitários foi fundamental para a criação do Ministério das Cidades" ${ }^{30}$.

A proposta de criação da Política Nacional de Desenvolvimento Urbano, além de uma determinação constitucional representa o coroamento dessas mudanças na forma de concepção, tratamento e suporte institucional para desenvolvimento de uma proposta macro de enfrentamento da crise urbana. O Ministério se propõe a um pacto social, de participação da sociedade, e um pacto federativo, de articulação dos entes federativos na formulação dessa proposta.

O texto base da nova PNDU que tem sido utilizado como referência nessa pesquisa foi primeiramente debatido e aprovado em plenária antes de ser publicado oficialmente. É sobre esse texto base da PNDU que têm se desenvolvido as demais discussões e atualizações da matéria em encontros do Conselho das Cidades e nas Conferências.

\footnotetext{
${ }^{29}$ Há críticas que ainda precisam ser devidamente fundamentadas quanto ao processo participativo, especificamente na forma de eleição dos delegados, nas votações nas conferências, na legitimidade das representações participantes, e se de fato a diversidade de atores da sociedade está representada no processo deliberativo.

${ }^{30}$ Idem ref. 33.
} 


\section{IV}

As Conferências das Cidades têm sido os fóruns principais de debates e deliberação a cerca do desenvolvimento urbano nacional.

Até 2007 foram realizadas três Conferências Nacionais, com pautas prédefinidas sobre temas diversos sobre os problemas urbanos, regionais e metropolitanos, visando definir ações para mitigação desses problemas, oportunizar o debate sobre as relações intergovernamentais e fortalecer a questão federativa, promover a participação social nos processos decisórios, e principalmente, avançar nas discussões sobre a Política Nacional de Desenvolvimento Urbano.

Como já referida, a $1^{\text {a }}$ Conferência Nacional das Cidades foi realizada em 2003, em Brasília, como as seguintes, sob o lema "Cidade Para Todos". Reuniu agentes sociais dos mais diversos segmentos, como movimentos populares, órgão de classe, parlamentares, instituições de ensino e pesquisa, empresários, todos esses atores reunidos em um amplo fórum de debates e proposições para a PNDU.

A Conferência teve por objetivos principais definir as diretrizes da PNDU e implantar o Conselho das Cidades. Nas várias conferências municipais e regionais que foram realizadas, se por um lado tiveram ampla adesão por parte dos governos estaduais e municipais, por outro, ainda há que se considerar que incorrem na possibilidade de distorções do processo, como disputas partidárias e cooptação de lideranças na eleição dos representantes para a conferência nacional. Mas certamente não se pode ignorar a mobilização que esse processo encerrou, e as proposições resultantes dos debates:

“(...) a Conferência avaliou cerca de 3.850 propostas originárias das conferências municipais e estaduais, e aprovou: (i) princípios, diretrizes, objetivos e ações da política urbana; (ii) as atribuições, a estrutura de funcionamento e a composição do Conselho das Cidades; e (iii) as diretrizes, os objetivos e as ações das políticas específicas de habitação, saneamento ambiental e mobilidade e trânsito. Por fim, ainda na Conferência, foi eleito o Conselho das Cidades formado por 71 membros e 27 observadores.(...). Avaliando o conteúdo das teses aprovadas, cremos que é possível afirmar que, de uma forma geral, as propostas aprovadas correspondem ao ideário da reforma urbana e estão em 
acordo com as principais reivindicações dos movimentos sociais ligados à reforma urbana, à habitação, ao saneamento ambiental e ao transporte" (MARICATO E SANTOS JR., 2007).

A $2^{\text {a }}$ Conferência Nacional das Cidades reforçou o tema da Reforma Urbana debateu sobre a participação e controle social, a questão federativa, a política urbana regional e metropolitana e o financiamento do desenvolvimento urbano nas Conferências Municipais, Regionais e Estaduais, que ainda elegeram o ConCidades em sua atual composição de 86 membros, dos quais $60 \%$ da sociedade e $40 \%$ do poder público ${ }^{31}$.

A transversalidade dos temas e o foco na região metropolitana também foram destaque na nessa segunda Conferência, que permitiu um avanço significativo na estruturação para elaboração da PNDU. Importante observar que a saída do Ministro Olívio Dutra teve um impacto significativo nesse processo (MARICATO e SANTOS Jr, 2007) - o que deve ser discutido mais à frente - abortando um importante aprofundamento no avanço na construção da PNDU que se estruturava nessa etapa ${ }^{32}$. Mesmo com a mudança de ministro, o processo continuou, o que se pode considerar de certa forma positivo, comprovando uma solidez na estrutura criada, apesar de o ritmo e da tônicas dos avanços terem sofrido modificações.

Deu-se seguimento à sistemática de Conferências, e realizou-se a $3^{\text {a }}$ Conferência Nacional das Cidades, em 2007, fazendo-se a mesma movimentação de conferências locais, discussões em fóruns diversos, com representantes da sociedade etc. Em termos de conteúdos para discussão, a proposta foi continuar com a construção da PNDU para o País, sem deixar de abordar temas centrais relacionados ao cotidiano da gestão do poder público nas três esferas de governo. Assim, propôs-se a discussão de temas que remetessem à capacidade de gestão dos governos locais e

\footnotetext{
${ }^{31}$ Essa relação de $40 \%$ poder público e $60 \%$ de participantes da sociedade tem sido um diretriz para a composição dos Conselhos Estaduais, Regionais e Municipais.

${ }^{32}$ Essa mudança ministerial se dá no bojo das negociações partidárias para formação de bancada de apoio ao presidente Lula, no seu segundo mandato, em 2005 (provando o que se falou sobre "presidencialismo de coalizão"). Curioso é observar que o novo ministro, Márcio Fortes, era de um partido de direita, o PP, e teve cargos ligados diretamente à presidência da República no período da ditadura militar (Membro do Grupo de Estudos sobre Direito Internacional Público e Política Internacional na Escola de Comando e Estado-Maior do Exército - 1966/67; Assistente do Secretário-Geral do Ministério das Relações Exteriores - 1965/66; Assistente do Secretário-Geral Adjunto para Organismos Internacionais do Ministério das Relações Exteriores - 1965; Chefe, substituto, da Divisão das Nações Unidas do Ministério das Relações Exteriores - 1964; Professor e Examinador dos Concursos do Instituto Rio Branco, do Ministério das Relações Exteriores - 1964/74;Redator e Revisor da equipe de elaboração das Mensagens Presidenciais ao Congresso Nacional - 1967/69)
} 
à capacidade dos governos federados de se articularem entre si, dentro do foco das relações intergovernamentais. Os temas principais foram:

Tema 1. A Política de Desenvolvimento Urbano e as Intervenções nas Cidades: Busca refletir como as políticas e os investimentos nos três níveis de governo estão contribuindo, ou não, para reverter a lógica da desigualdade e da exclusão territorial, bem como, para reverter a lógica de fragmentação e desarticulação das intervenções setoriais e intergovernamentais.

Tema 2. Capacidade e Forma de Gestão das Cidades: Busca refletir em que medida os governos estão estruturados para enfrentar os desafios de seu próprio desenvolvimento, a partir de uma reflexão sobre como as políticas e investimentos nos três níveis de governo estão contribuindo, ou não, para reverter a fragilidade do poder público em planejar o desenvolvimento e as intervenções nas cidades de forma integrada e com participação social. ${ }^{33}$

Os dados sobre os temas das Conferências Nacionais, o total de conferências estaduais e municipais realizadas e o balanço da participação dos diversos segmentos sociais nas Conferências nacionais seguem compilados nos Quadros 4, 5 e 6, que seguem. $^{34}$

Quadro 2 - Quadro-resumo sobre as Conferências Nacionais das Cidades.

\begin{tabular}{|c|c|c|c|c|}
\hline & & ADES & & \\
\hline $\begin{array}{l}\text { Conferências } \\
\text { Nacionais }\end{array}$ & Ano & Lema & Temas & Temas para debate \\
\hline $\begin{array}{l}\text { 1' Conferência } \\
\text { das Cidades }\end{array}$ & 2003 & Cidade para Todos & $\begin{array}{l}\text { Construindo uma } \\
\text { política democrática e } \\
\text { integrada para as } \\
\text { cidades }\end{array}$ & A PNDU e o Conselho das Cidades \\
\hline $\begin{array}{l}2^{\text {a }} \text { Conferência } \\
\text { das Cidades }\end{array}$ & 2005 & $\begin{array}{l}\text { Reforma Urbana: } \\
\text { Cidade para Todos }\end{array}$ & $\begin{array}{l}\text { Construindo a } \\
\text { Política Nacional de } \\
\text { Desenvolvimento } \\
\text { Urbano" }\end{array}$ & $\begin{array}{l}\text { Participação e Controle Social; Questão } \\
\text { Federativa; } \\
\text { Política Urbana Regional e Metropolitana e } \\
\text { Financiamento do Desenvolvimento Urbano }\end{array}$ \\
\hline $\begin{array}{l}\text { 3. Conferência } \\
\text { das Cidades }\end{array}$ & 2007 & $\begin{array}{l}\text { Desenvolvimento } \\
\text { urbano com } \\
\text { participação } \\
\text { popular e justiça } \\
\text { social }\end{array}$ & $\begin{array}{lrr}\begin{array}{l}\text { Avançando } \\
\text { democrática }\end{array} & \text { gestão } \\
\text { cidades } & & \text { das } \\
\end{array}$ & $\begin{array}{l}1.1 \text { - As Intervenções Urbanas e a } \\
\text { Integração de Políticas; } \\
1.2 \text { - As Intervenções Urbanas e o Controle } \\
\text { Social; } \\
1.3 \text { - As Intervenções Urbanas e os } \\
\text { Recursos; } \\
2.1 \text { - Capacidade Administrativa e de } \\
\text { Planejamento e Estrutura Institucional } \\
2.2 \text { - Receitas Municipais e Ampliação de } \\
\text { Receitas próprias }\end{array}$ \\
\hline $\begin{array}{l}4^{\text {a }} \text { Conferência } \\
\text { das Cidades }\end{array}$ & $\begin{array}{l}\text { Previsão } \\
2010\end{array}$ & $\begin{array}{l}\text { Cidade para todos } \\
\text { e todas com gestão } \\
\text { democrática, } \\
\text { participativa } \\
\text { controle social }\end{array}$ & $\begin{array}{l}\text { Os avanços } \\
\text { dificuldades para a } \\
\text { efetiva implementação } \\
\text { da Política Nacional de } \\
\text { Desenvolvimento } \\
\text { Urbano - PNDU }\end{array}$ & $\begin{array}{l}\text { - Criação e implementação de conselhos das } \\
\text { cidades, planos, fundos e seus conselhos } \\
\text { gestores nos níveis federal, estadual, } \\
\text { municipal e no Distrito Federal } \\
\text { - Aplicação do Estatuto da Cidade, dos } \\
\text { planos diretores e a efetivação da função } \\
\text { social da propriedade do solo urbano } \\
\text { - A integração da política urbana no território: } \\
\text { política fundiária, mobilidade e acessibilidade } \\
\text { urbana, habitação e saneamento } \\
\text { - Relação entre os programas }\end{array}$ \\
\hline
\end{tabular}

${ }^{33}$ INFORMAÇÕES SOBRE O PROCESSO DE REALIZAÇÃO DA $3^{\text {a }}$ CONFERÊNCIA NACIONAL DAS CIDADES. Disponível em < www.cidades.gov.br> Acesso em 10.05.2010.

${ }^{34}$ FONTES: Publicações e relatórios sobre as conferências. Disponíveis em <www.cidades.gov.br> Acesso em 10.05.2008. 


\begin{tabular}{|l|l|l|l|}
\hline & & & $\begin{array}{l}\text { governamentais - como PAC e Minha Casa, } \\
\text { Minha Vida - e a política de desenvolvimento } \\
\text { urbano }\end{array}$ \\
\hline
\end{tabular}

Quadro 3 - Balanço da realização de conferências das cidades nos Estados e Municípios.

\begin{tabular}{|c|c|c|c|c|}
\hline Etapas & Dados & 1a Conferência & 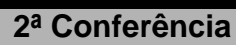 & $3^{a}$ Conferência \\
\hline \multirow[t]{4}{*}{ Preparatórias } & $\begin{array}{l}\text { Total de } \\
\text { Conferências } \\
\text { Municipais }\end{array}$ & 1430 & 869 & 1554 \\
\hline & $\begin{array}{l}\text { Total de } \\
\text { Conferências } \\
\text { Regionais }\end{array}$ & 150 & 243 & 150 \\
\hline & $\begin{array}{l}\text { Total de } \\
\text { Municípios } \\
\text { que participaram }\end{array}$ & 3457 & 3120 & 3277 \\
\hline & $\begin{array}{l}\text { Total de } \\
\text { Conferências } \\
\text { Estaduais }\end{array}$ & 27 & 27 & 27 \\
\hline Nacional & $\begin{array}{l}\text { Total de delegados } \\
\text { participantes }\end{array}$ & 2095 & 1820 & 2040 \\
\hline
\end{tabular}

Quadro 4 - Balanço da participação dos diversos segmentos na $1^{\mathrm{a}}, 2^{\mathrm{a}}$ e $3^{\mathrm{a}}$ Conferência Nacional das Cidades.

\begin{tabular}{|c|c|c|c|}
\hline SEGMENTOS & 1a Conferência & $2^{a}$ Conferência & $3^{\text {a }}$ Conferência \\
\hline $\begin{array}{ll}\text { PODER } & \text { PÚBLICO } \\
\text { FEDERAL* } & \end{array}$ & 189 & 147 & 137 \\
\hline $\begin{array}{ll}\text { PODER } & \text { PÚBLICO } \\
\text { ESTADUAL } & \end{array}$ & 232 & 167 & 200 \\
\hline $\begin{array}{ll}\text { PODER } & \text { PÚBLICO } \\
\text { MUNICIPAL } & \end{array}$ & 390 & 354 & 367 \\
\hline $\begin{array}{l}\text { MOVIMENTOS } \\
\text { POPULARES }\end{array}$ & 541 & 561 & 695 \\
\hline TRABALHADORES & 203 & 180 & 219 \\
\hline EMPRESÁRIOS & 153 & 156 & 187 \\
\hline $\begin{array}{l}\text { ENTIDADES } \\
\text { ACADÊMICAS }\end{array}$ & 190 & 89 & 145 \\
\hline $\begin{array}{l}\text { Operadores } \\
\text { concessionários públicos }\end{array}$ & 117 & & \\
\hline Concessionários privados & 80 & & \\
\hline ONGs & & 74 & \\
\hline Conselhos de Classe & & 21 & \\
\hline $\begin{array}{l}\text { Conselho Nacional das } \\
\text { Cidades }\end{array}$ & & 71 & \\
\hline TOTAIS & 2095 & 2230 & 2040 \\
\hline
\end{tabular}

* Inclui poder público executivo e legislativo 


\title{
2.2.3. Planos, programas e ações propostos
}

Os programas, planos e ações propostos da política de desenvolvimento urbano, são definidos a partir de suas "Propostas Estruturantes", que seguem a estruturação setorial do Ministério das Cidades, apesar do reconhecimento da necessidade de integração dessas políticas na PNDU ${ }^{35}$.

\author{
PROPOSTAS ESTRUTURANTES DA PNDU ${ }^{36}$ \\ I. Implementação dos instrumentos fundiários do Estatuto da Cidade \\ II. Novo Sistema Nacional de Habitação \\ III. Promoção da mobilidade sustentável e cidadania no trânsito \\ IV. Novo marco legal para o saneamento ambiental \\ V. Capacitar e Informar as cidades
}

Segue então uma breve descrição dos programas, planos e ações proposto dentro de cada setor.

\section{I}

A primeira proposta estruturante da PNDU tem na função social da cidade e da propriedade urbana o fundamento de suas ações. A questão fundiária, como elemento central nos conflitos urbanos, assume relevância ímpar nesse contexto, uma vez que é pelo valor da terra e pela apropriação privada do espaço urbano que claramente se desvirtua o princípio da função social cidade pela função econômica da propriedade e da terra urbana.

A expectativa de minoração desses quadros de segregação e espoliação urbana pela nova PNDU está na aplicação dos instrumentos do Estatuto via Planos Diretores,

\footnotetext{
35 "No reconhecimento de que políticas setoriais são indispensáveis e podem ser estruturantes do desenvolvimento urbano é fundamental entender que elas tanto mais o serão, na direção hoje pretendida, quanto mais estiverem integradas numa Política Nacional de Desenvolvimento Urbano, e que ela também se articule com outras políticas governamentais - horizontalmente, no âmbito federal, e verticalmente, na direção de estados e municípios". (MINISTERIO DAS CIDADES, 2004a , p. 55)

${ }^{36}$ As políticas estruturantes são os "braços" da PNDU, mas cada uma delas encerra uma complexa estrutura institucional e programática de suas ações que certamente exigem muito mais detalhamentos do que essa tese pode comportar. Por isso as referências aqui colocadas não encerram nem esgotam a totalidade de possibilidades analíticas desses eixos estruturante da PNDU de 2004, mas também não ignoram a sua relevância como bases de ação da política de desenvolvimento urbano.
} 
o instrumento básico do planejamento urbano municipal. Tanto o planejamento quanto a gestão municipal têm sofrido pela inocuidade e ineficiência das últimas décadas, tanto pelas heranças do planejamento territorial racional e tecnocrático do passado, quanto pela imposição de sobrecarga de competências municipais, sem as suficientes contrapartidas técnico-financeiras mediante a nova condição do muncipio de ente federado a partir de 1988.

Partindo desse quadro, o Governo Federal se coloca como agente relevante no processo de renovação do planejamento urbano através do financiamento e apoio técnico à elaboração e revisão dos Planos Diretores municipais, imperativa para municípios acima de 20 mil habitantes. Por isso a Política de Apoio à Elaboração e Revisão de Planos Diretores tem como missão "estimular os municípios a novas práticas democráticas e participativas de gestão e planejamento territorial", tendo em vista "instrumentos de captura da valorização fundiária e promoção da Habitação de Interesse Social previstos no Estatuto da Cidade" (MINISTÉRIO DAS CIDADES, 2004a, 2004b).

Dentro do eixo da política fundiária da PNDU, foi proposta a Política Nacional de Prevenção de Risco em Assentamentos Precários, para tratar das áreas de risco, com o conceito de remoção de risco das áreas de encosta - assentamento precário presente nas maiores regiões metropolitanas - entendendo-se que a remoção de favelas pode representar um custo social, político e financeiro muito maior e desgastante.

Outra proposta é a Política Nacional de Apoio à Reabilitação de Centros Urbanos, visando o aproveitamento e a ocupação de áreas centrais, com completa infra-estrutura urbana, subaproveitadas ou abandonadas, em contraposição à expansão urbana periférica pela população de baixa renda.

Dentro do escopo de "terra urbanizada para todos", prevê-se também ações no sentido de simplificação dos processos de regularização fundiária, legislativos, cartorários, urbanísticos e ambientais, para que a "cidade ilegal" ou "informal" tenha uma extensão cada vez menor de terras urbanas incluídas nessas alcunhas.

II

A herança histórica da atuação do governo federal no plano habitacional remonta desde a década de quarenta, mas tem nas décadas de 1960 e 1970, sob o 
comando do BNH, o marco de investimentos massivos na construção de habitação que deveria privilegiar o interesse social, mas que sofreu vieses diversos pelos interesses de mercado, interferindo em fatores de clientela, locacionais e de qualidade técnica das unidades produzidas para a baixa renda.

A proposta de um Novo Sistema Nacional de Habitação fundado na proposta da nova Política Nacional de Habitação tem como seu objetivo principal de ação a garantia do direito de acesso à moradia por todos os segmentos da população, principalmente os de baixa renda, historicamente desprovidas dessas garantias.

As linhas mestras de atuação da Política Nacional da Habitação são a Integração Urbana de Assentamentos Precários, a Provisão da Habitação e a Integração da Política de Habitação à Política de Desenvolvimento Urbano. Os vários programas decorrentes dessas linhas de ação se voltam à regularização da propriedade, como o programa Papel Passado, e à construção de novas unidades habitacionais de interesse social como o Programa de Apoio à Provisão Habitacional de Interesse Social.

A PNH conta com um conjunto de instrumentos para sua implementação, como - Sistema Nacional de Habitação (SNH), o Desenvolvimento Institucional, o Sistema de Informação, avaliação e monitoramento da habitação e o Plano Nacional de Habitação. O Desenvolvimento Institucional prevê a estruturação institucional dos Estados e Municípios, e a capacitação de seus agentes públicos de forma a viabilizar a descentralização das políticas habitacionais. Prevê também apoio financeiro aos subgovernos na melhoria das condições de habitação e requalificações urbana, como o Pró-Moradia, além das várias modalidades de Cartas de Crédito, com recursos do FGTS geridos pela CEF, ou financiamento direto da construção como os Programas de Arrendamento Residencial (PAR) e programas habitacionais dos Estados e Municípios, incentivados pelo programa de Apoio à Elaboração de Planos Locais de Habitação de Interesse Social.

O Sistema de Informação, Avaliação e Monitoramento da Habitação (SIMAHAB) pretende garantir a revisão permanente para possível redirecionamento da política habitacional e de seus programas. O Plano Nacional de Habitação, por sua vez, deverá estabelecer: "metas de médio e longo prazo; as linhas de financiamento; e os programas de provisão, urbanização e modernização da produção habitacional a 
serem implementados a partir das prioridades regionais de intervenção e critérios para a distribuição regional de recursos, de acordo com perfil do déficit habitacional no âmbito nacional." (MINISTÉRIO DAS CIDADES, 2004c, p. 30).

O PlanHab é ainda um plano em construção (iniciado em 2007) que deve definir as ações programáticas mais específicas dentro do setor habitacional. É parte de um processo de planejamento de longo prazo do Governo Federal, que pressupõe revisões periódicas e articulação com outros instrumentos de planejamento e orçamento, como o Plano Plurianual (PPA). "O PlanHab, quando finalizado, orientará o planejamento das ações públicas e privadas com o objetivo de melhor direcionar os recursos existentes e aqueles a serem mobilizados para o enfrentamento das necessidades habitacionais do país". ${ }^{37}$

\section{III}

A Promoção da mobilidade sustentável e cidadania no trânsito é outro eixo de atuação da PNDU que tem como objetivo mudança nos padrões de políticas públicas de transporte e trânsito centradas no automóvel para centrá-las no indivíduo, na perspectiva do que tem sido chamado de "sustentabilidade da mobilidade urbana".

Isso implica em inversões de prioridades: além do privilégio do transporte coletivo sobre o individual, "da integração das redes e modos sobre as obras isoladas e unimodais, da acessibilidade universal sobre a acessibilidade restrita, a consolidação de múltiplas centralidades sobre o reforço de poucas centralidades; o adensamento urbano sobre a extensão da cidade" (MINISTÉRIO DAS CIDADES, 2004a, p. 63).

Está em andamento desde 2007 o Projeto de Lei da Mobilidade Urbana - PL 1687/2007 que institui as diretrizes da Política de Mobilidade Urbana. A política de mobilidade urbana tem como objetivo contribuir para o acesso universal à cidade, por meio do planejamento e gestão do Sistema de Mobilidade Urbana.

A Política Nacional de Mobilidade têm como macro-objetivos o desenvolvimento urbano, a sustentabilidade urbana e a inclusão social. Com relação ao desenvolvimento urbano, a preocupação se funda sobre a integração entre transporte e controle territorial, redução das deseconomias da circulação e a oferta de transporte público eficiente e de qualidade (MINISTÉRIO DAS CIDADES, 2004d, p. 50).

\footnotetext{
${ }^{37}$ Fonte: Ministério das Cidades (www.cidades.gov.br).
} 
Os programas relativos ao trânsito e mobilidade urbana se estruturam pela prática do planejamento integrado de transporte e uso do solo urbano, a atualização da regulação e gestão do transporte coletivo urbano, a promoção da circulação não motorizada e o uso racional do automóvel. Foram definidos os programas a partir da PNDU: Programa Mobilidade Urbana; Pró-Transporte; Bicicleta Brasil; Brasil Acessível; e Pró-Mob.

O Programa de Mobilidade Urbana encerra cinco ações que abrangem desde sistemas integrados de transporte coletivo urbano à urbanização de áreas lindeiras a corredores ferroviários. O Pró-Transporte concentra ações sobre a melhoria qualitativa do transporte coletivo, desde aumento da velocidade operacional, melhoria dos pontos de parada e abrigos, a integração intermodal dos sistemas.

O programa Brasil Acessível tem o objetivo de estimular os governos a desenvolverem ações que garantam "acessibilidade para pessoas com restrição de mobilidade aos sistemas de transporte" (Idem, p. 56). O Programa Brasileiro de mobilidade por bicicleta tenta agregar o modo bicicleta às políticas de mobilidade urbana sustentável e às de inclusão social, integrando aos demais modos de transporte e reduzindo os custos de mobilidade para milhões de pessoas.

Além desses programas, o setor dos Transportes conta com a integração do Departamento Nacional de Trânsito à estrutura do Ministério das Cidades, partindo do reconhecimento dos impactos do trânsito sobre a gestão urbana. Assim, programas dentro da Política Nacional de Trânsito visam minimizar questões de segurança, congestionamentos, e disciplinamento e regulação dos diversos modos de transportes pelas vias municipais, estaduais e federais, por meio de campanhas educativas, inovações tecnológicas, e melhorias nos sistemas de gestão de competência de cada esfera governamental, com atenção especial aos Municípios (MINISTÉRIO DAS CIDADES, 2004e).

\section{IV}

No setor de saneamento, o histórico das ações do governo federal tem como referência a atuação do $\mathrm{BNH}$, assim como na habitação, na centralização de recursos e gestão da implementação do PLANASA, maior plano de investimento na área até 
então, que possibilitou o abastecimento de água e a ampliação da rede de esgotos em inúmeras cidades na década de 1970, tendo como sua base institucional de apoio as companhias estaduais e municipais de abastecimento.

Mas o crescimento do número de municípios e as ocupações periféricas das grandes cidades têm aumentado consideravelmente a demanda por saneamento básico nos últimos anos, que têm contado com políticas de investimentos irregulares no setor e sofrido com uma gestão "pulverizada" e desarticulada setorial e institucionalmente.

A busca de um novo marco para o saneamento ambiental para a nova PNDU passa tanto pela renovação do processo institucional de gestão, como pela criação de uma Política Nacional de Saneamento que possa garantir a universalização do atendimento às diversas funções encerradas no conceito de saneamento ambiental, quais sejam "abastecimento de água potável, esgotamento sanitário (coleta, tratamento e destinação final), gestão de resíduos sólidos urbanos (coleta, tratamento e disposição final), além do adequado manejo de águas pluviais urbanas, com o conseqüente controle de enchentes".

Os programas e ações propostos nesse setor visam: o enfrentamento do déficit de atendimento a esses serviços principalmente nas áreas metropolitanas e municípios de pequeno porte (Programa de Saneamento Integrado em Pequenos Municípios PSS-BIRD e Saneamento Ambiental Urbano); a recuperação ambiental de áreas degradadas (PAT-Sanear); conjugar ações estruturantes para uma gestão integrada de resíduos sólidos com capacitação de agentes públicos (Gestão Integrada de Resíduos Sólidos e Programa de Capacitação); uma gestão sustentável da drenagem urbana, para prevenção e controle dos impactos das enchentes urbanas (Drenagem Sustentável) ; combate ao desperdício de água e energia em saneamento (Programa Nacional de Combate ao Desperdício de Água - PNCDA); e programas de apoio ações de infra-estrutura urbana na área de saneamento em municípios de porte diferenciado (Programa Pró-Municípios). (MINISTÉRIO DAS CIDADES, 2004f, p.71).

\section{$\mathbf{V}$}

Com relação à capacitação de órgãos da estrutura institucional e agentes da sociedade, a gestão e implementação do programas, planos e ações decorrentes das 
demandas do desenvolvimento urbano alinhadas à PNDU certamente exige uma capacidade técnica, coordenativa e de gestão a que muitos órgãos e atores podem não corresponder adequadamente, tanto nas três esferas de poder, que contam com arranjos institucionais diversos, como na participação dos diversos seguimentos em vários desse processo:

"A capacitação de agentes públicos e sociais para as políticas públicas urbanas integradas constitui uma das tarefas mais importantes para a promoção do direito à cidade. Não se trata de desenvolver uma capacitação supostamente destituída de conteúdo político, mas de impulsionar a formação de sujeitos sociais capazes de intervir no debate sobre a política urbana e de lidar com aspectos críticos da contemporaneidade, especialmente no que diz respeito à redução das desigualdades sociais e à justa distribuição dos ônus e benefícios da urbanização" (MINISTÉRIO DAS CIDADES, 2004a, p. 68).

Tendo em vista a necessidade não só de capacitação, mas também de informação a cerca do processo empreendido, esse eixo estruturante da PNDU prevê ações que forneçam subsídios para que essas fragilidades não sejam impeditivos à implementação das diretrizes de desenvolvimento, ou não se perca de vista a necessidade da informação para capacitação, monitoramento e avaliação de suas políticas, programas e ações.

O principal meio de implementação das ações desse eixo estruturante da PNDU é o Programa Nacional de Capacitação de Cidades - PNCC, que assume um caráter transversal e intersetorial, uma vez que "promove, coordena e apóia programas e ações voltados para a capacitação de agentes públicos e sociais e para o apoio ao setor público municipal e estadual para o desenvolvimento institucional", ou seja, contempla o poder público em suas diversas esferas de atuação, a sociedade, e apóia os diversos setores, como habitação, saneamento e transportes, tanto na formação de pessoal capacitado, quanto na produção de informação aos menos capacitados.

O PNCC atua por diversos meios de capacitação, seja por seminários, oficinas, workshops, cursos presenciais ou à distância, seja no financiamento de pesquisas para produção de diagnósticos e quadros sobre a realidade do desenvolvimento urbano e publicações de apoio, seja ainda pela construção de sistemas de informações, com aportes tecnológicos, para integração de dados e disponibilização e meios acessíveis ao conjunto de interessados. 
São os seguintes os principais programas e ações do PNCC:

- "Apoio à capacitação de municípios e agentes sociais para o desenvolvimento urbano;

- Programa de Capacitação para Elaboração de Planos Diretores Participativos e Ações de Regularização Fundiária Sustentável;

- Capacitação de Equipes Municipais para Prevenção de Riscos em Assentamentos Precários;

- Programa Habitar Brasil BID - Subprograma de Desenvolvimento Institucional de Municípios;

- Programa de Modernização do Setor de Saneamento;

- Programa Nacional de Combate ao Desperdício de Água;

- Projeto de Assistência Técnica ao Programa de Saneamento Integrado para População de Baixa Renda;

- Programa de Treinamento e Capacitação à Distância em Gestão Integrada de Resíduos Sólidos;

- Programa de Ação Social em Saneamento;

- Programa de Capacitação da Secretaria Nacional de Transporte e Mobilidade Urbana;

- Programa de Capacitação do Denatran;

- Capacitação para construção de índices de qualidade de vida intraurbanos" (MINISTÉRIO DAS CIDADES, 2004a, p. 70).

\section{VII}

A PNDU, como diretriz das ações governamentais, previu programas, ações e transferências de recursos financeiros em vários âmbitos de políticas públicas

Nesses cinco primeiros anos de sua atuação, o Ministério das Cidades, observando as diretrizes básicas da PNDU, tem desenvolvido programas e ações pelos quais se conta tanto progressos significativos em algumas áreas, como habitação e saneamento, para o qual tem sido direcionada a maior parte dos investimentos, devido ao passivo histórico que recai sobre essas áreas, mas também promovendo ações de urbanização e regularização fundiária, e criação e aprovação de leis estratégicas, como o marco regulatório do saneamento e o da mobilidade urbana.

Além disso, elaboração dos planos diretores em vários municípios, programas de capacitação e modernização administrativas das prefeituras, os programas de aceleração do crescimento, os planos e fundos criados na área de habitação de 
interesse social compõem um quadro preliminar relevante de ações para o desenvolvimento urbano ${ }^{38}$.

Esses são alguns dos componentes do debate que segue sobre as políticas nacionais de desenvolvimento urbano, passando a pesquisa agora à etapa comparativa das duas políticas, sob aspectos comuns considerados relevantes para compreender suas proposições e constatar resultados e/ou impactos que cada uma trouxe em seus contextos específicos.

38 Um quadro mais detalhado sobre esses programas, projetos e ações do Ministério das Cidades a partir do início do processo de elaboração da PNDU, 2004, será desenvolvido na etapa posterior de elaboração da tese, com o objetivo de analisar com maior embasamento os pontos críticos na implementação dessas políticas. 
Capítulo 3 


\section{EIXOS COMPARATIVOS - Contextos, pressupostos e princípios}

Essa parte da pesquisa tomou forma a partir do conhecimento dos conteúdos e propostas das Políticas Nacionais de Desenvolvimento Urbano, que permitiram a identificação de questões comuns às duas PNDUs.

Cada aspecto comparativo escolhido compõe um item, e sobre cada "temática" propõe-se uma breve revisão sobre os contextos e debates acerca do tema em que esses eixos se inserem, a comparação das propostas específicas de cada PNDU e em seguida considerações gerais sobre pontos considerados mais relevantes do debate.

\subsection{ASPECTOS POLÍTICOS E SÓCIO-ECONÔMICOS}

\subsubsection{Contextos e debates: economias periféricas e golpes militares na América} Latina e a "ditadura do milagre" no Brasil

I

A partir da segunda metade do Século XX, no pós-II Guerra mundial (1945), a Guerra Fria dividiu o mundo em dois blocos que disputavam a hegemonia política e econômica mundiais, principalmente dos continentes mais subdesenvolvidos (Ásia, América - Latina, África e/ou países do sul), polarizados pelos centros desenvolvidos do norte (América do Norte e Europa principalmente). Era a disputa entre o capitalismo e socialismo, liderados pelos Estados Unidos, o primeiro bloco, e o segundo pela extinta União Soviética.

As economias periféricas antes da guerra cumpriam papéis subordinados na nova divisão internacional do trabalho, como retaguardas de matérias primas e consumidoras dos produtos industrializados dos países do centro. Até que o princípio da "autodeterminação"39 (liberdade das nações determinarem soberanamente os

\footnotetext{
${ }^{39}$ Assinado pelos países aliados na Carta das Nações em 1945, após o fim da Segunda Guerra Mundial.
} 
rumos de seu desenvolvimento) deflagrou um processo de descolonização global pelos países do Terceiro Mundo em busca do seu desenvolvimento como dos países "modelo".

Mas o patamar de "pobreza" de alguns países, ou de uma economia dependente de outros, levava à aceitação das crenças que somente pelas vias de "revolução do campesinato" ou por outra via, a "modernização" e eficiência do Estado, poderiam alavancar o desenvolvimento dessas nações subordinadas, retirando-as da "atrasada" economia agrícola exportadora para a "moderna" economia industrial capitalista produtora e consumidora (ROBSBAWN, 1995).

Fosse por via do modelo do planejamento totalmente centralizado pelo Estado, como preconizado pela União Soviética, fosse pelo modelo de "substituição de importações" apoiado pelo liberalismo americano, essa ideologia de que somente um Estado forte e centralizado seria capaz de proporcionar as transformações necessárias e implementar diretrizes econômicas encontrava eco nos países periféricos do capitalismo, principalmente na América Latina. A substituição de importações e o desenvolvimentismo foram apoiados pela Comissão para o Desenvolvimento da América Latina e Caribe (CEPAL, braço da ONU-Organização das Nações Unidas), e tiveram seus fundamentos implantados ainda na década de 1950 no Brasil.

Era também parte das teorias do pós-guerra, o pluralismo ${ }^{40}$, que defendia que "à medida que as sociedades de baixa renda fossem mais capitalistas (modernas) e menos tradicionais, elas se tornariam mais democráticas, baseada na lógica racionalista das relações, que deveria ser capaz de suplantar as instituições políticas particularistas e autoritárias (CARNOY, 1988). Essa previsão claramente não se cumpriu, e o que se viu foi o direcionamento dos Estados periféricos justamente para governos autoritários e dependentes das economias centrais. ${ }^{41}$

A partir da segunda metade do Século $X X$, os golpes militares tiveram seu lugar nos governos latino-americanos, dentre eles o Brasil. No caso brasileiro, num momento

\footnotetext{
${ }^{40}$ cf. Shumpeter (1984)

${ }^{41}$ CARNOY (1988): "o advento do autoritarismo do Terceiro Mundo não é somente uma reposta essencialmente 'necessária' para a crise - uma expressão das burguesias inerentemente frágeis do Terceiro Muncdo, e do poder do capital estrangeiro sobre aqueles Estados - mas pode ser o prenúncio da institucionalização do militarismo na periferia. Frank observa que a 'militarização do Estado e, na verdade, da democracia, sociedade, cultura e ideologia também está-se induzindo além e abaixo da superfície imediatamente visível, em um país após outro'. Frank, 1979, 42, citado por, Carnoy).
} 
de fragilidade democrática e crise econômica no início da década de 1960, um grupo de militares aproveitou-se do discurso de "defesa da democracia" e do "anticomunismo", para tomar o poder executivo nacional. Esse grupo de conservadores de extrema direita manteve-se no governo sob a égide da defesa do Estado como a instituição nacional capaz de proporcionar a sua inserção no circuito capitalista mundial, saindo definitivamente de sua condição de país "atrasado" para "moderno", daí a expressão "modernização conservadora", uma vez que se faz dentro de um contexto de conservadorismo político, sem que houvesse muitas mudanças estruturais profundas.

A ascensão dos regimes ditatoriais na América Latina nas décadas de 1960 e 1670 (Chile, Argentina, Paraguai, Uruguai, Brasil) era imbuída do intuito políticoideológico de reprimir a "esquerdização" desses governos, bem como pelo fito econômico de inserção definitiva no circuito da "modernização industrial" e do "desenvolvimentismo", que era visto como solução para a crise por que passavam boa parte desses países. Brasil e México destacaram-se como economias da América Latina que, malgrado os custos financeiros, políticos e sócio-econômicos desse processo, conseguiram fazer modernização de suas economias.

II

O centralismo autoritário, marcado pela força reguladora do Estado em praticamente todos os aspectos da vida pública (político, econômico, social, cultural), foi sem dúvida a principal marca dos governos militares durante os regimes ditatoriais latino-americanos nas décadas de 1960 e 1970.

No Brasil não foi diferente. A repressão a manifestações populares, sindicais, ou quaisquer outras contrárias ao governo, e exclusão da sociedade de qualquer processo decisório ou liberdade políticas participativa era patente e tomada como forma de conduzir com "mão de ferro" o desenvolvimento do País nos "anos de chumbo" (1968-1975).

O cerceamento das liberdades políticas, a censura sobre as manifestações culturais e artísticas, a perseguição a opositores políticos, eram escamoteados pela forte propaganda positiva do regime sobre si mesmo, disseminando a ideologia ufanista 
do "Brasil grande potência" ${ }^{42}$, com discursos que se revestiam da democratização para adquirir adeptos, enquanto na prática se aprofundavam as medidas autoritárias do regime instaurado.

Davam respaldo jurídico às arbitrariedades dessa "corte", os "Atos Institucionais" (emitidos em um total de dezessete) e seus complementos, pelos quais - País passou a ser governado. Essas peças legislativas sobrepuseram-se à Constituição Federal de 1967 e às legislações estaduais, e aos poderes judiciário e legislativo, pelo que se determinou a dissolução do Congresso por um ano, adoção do bipartidarismo (ARENA, direita, e MDB, centro-esquerda), eleições indiretas, cassações de direitos políticos e uma série de outras medidas que pudessem "engessar" os opositores do regime, e fortalecer o executivo para viabilizar suas manobras.

A centralização pelo governo federal não procurava controlar somente os seus opositores políticos internos e os movimento populares (sindicais, artísticos, intelectuais, eclesiais), mas procurava abafar também o poder das oligarquias estaduais e regionais, a fim de evitar perda de poder também nos níveis subnacionais (ABRUCIO, 2005).

No Brasil, essa não é propriamente uma relação dos dias atuais, porquanto o Estado brasileiro carrega uma herança de já nascer sob as imposições de uma metrópole pré-existente, e permanece subjugado pelo poderio econômico central em voga $^{43}$. O crescimento econômico do país é, então, em muitos momentos, balizado por interesses privados em lugar do coletivo, gerando embates entre os distintos atores e grupos sociais, entre cidades e regiões, nas disputas por investimentos e recursos, estabelecendo-se, assim, uma relação intrínseca entre economia, sociedade e território.

A tentativa de concentrar poder e cooptar lideranças nos mais diversos níveis e esferas públicas era uma prática diametralmente oposta aos discursos de "defesa da democracia", descentralização e autonomia aos demais níveis de governo. O Estado assumiu o papel de regulador das políticas e cercou-se de todo um aparato

\footnotetext{
${ }^{42}$ Reforçada pelas doutrinas da Escola Superior de Guerra, referência do projeto geopolítico nacional, como visto no Capítulo 1.

${ }^{43}$ Cf. DAIN, S. E LESSA (1982).
} 
tecnocrático e institucional para ter total controle dos processos de tomada de decisão, elaboração e implementação das políticas e diretrizes nacionais nas mais diversas áreas, mas de forma prioritária, nas políticas e planos para o desenvolvimento econômico nacional.

\section{III}

No campo econômico, com a herança do desenvolvimentismo ${ }^{44}$ e das políticas de substituição de importações do governo Juscelino Kubitschek, manteve-se a meta de crescimento da produção industrial, porém agora sobre bases nacionais (como alternativa à invasão - e evasão - do capital estrangeiro que gerou altos índices inflacionários e dívida externa no governo JK). Tinha como foco as diretrizes keynesianas de criação de grandes empresas estatais e investimento na indústria pesada (siderurgia, energia, petróleo, construção naval), além da garantia de provisão da infra-estrutura de estradas, energia, transporte, essenciais para o instalação "do progresso e do desenvolvimento" nacionais.

O "milagre" do crescimento da economia nacional experimentado entre 1968 e 1973, favorecido pelo combate à inflação e reformas estruturais, justificava a ingerência federal nos mais diversos setores, níveis de governo e escalas territoriais ${ }^{45}$. A burocracia nacional enxergava o País como uma potência emergente, pois se tinha a ilusão de que o Estado, com todos os mecanismos fiscais e monetários nas mãos, conseguiria manter o milagre e sobrepor-se às crises interna e mundial, absorvendo o .primeiro choque do petróleo. Nesse momento os esforços do governo começam a se dividir entre duas direções: uma expansionista, visando à manutenção do acelerado crescimento econômico do período anterior, e outra contencionista, propondo o controle da inflação ${ }^{46}$.

\footnotetext{
${ }^{44}$ Política Econômica do Plano de Metas "50 anos em 5".

45 "O capitalismo monopolista de Estado assume no Brasil características particulares, decorrentes da própria industrialização tardia. Há que ressaltar três traços que the conferem especificidade: a importância crucial do setor produtivo estatal, a profundidade do processo de internacionalização do sistema produtivo e a extensão do controle do Estado sobre o processo de acumulação. (BELLUZZO e MELLO, 1982, p. 144).

${ }^{46}$ Para os tecnocratas conservadores a ditadura representou uma oportunidade extraordinária para a aplicação de sua orientação pretensamente racional e eficiente à política econômica, uma vez suprimidas de um golpe quaisquer propostas alternativas enraizadas no nacional-desenvolvimentismo e as possibilidades de mobilização popular em seu apoio. A face austera exibida pelo regime durante o governo Castello Branco por um momento descortinou um horizonte favorável à implementação duradoura desse enfoque para a política econômica, estendendo-se pelo tempo que fosse necessário à obtenção de seus frutos. Contudo, como logo se viu, mesmo os ortodoxos defensores da austeridade tinham o seu apoio pelo regime e pelo empresariado condicionado ao cumprimento de promessas definidas ainda em 1964: uma redução da inflação para $10 \%$ a.a. e a retomada do crescimento a taxas ao redor de $6 \%$ a.a. quando do término do governo Castello Branco. A restauração da lucratividade do
} 
No entanto, a partir de 1973, o choque da crise internacional do Petróleo faz estremecer as bases econômicas nacionais e torna mais nítidas as fragilidades conjunturais sobre as quais se assentavam a euforia desenvolvimentista-milagrosakeynesiana. O ano de 1975 marcou o início do desmoronamento do milagre econômico e inaugurou um longo período de uma recessão que se estenderia durante toda a década de 1980 e 1990 (as chamadas décadas perdidas), até encontrar na estabilização da moeda nacional e na contenção da inflação o rumo para a retomada do crescimento nacional de forma mais sustentada ${ }^{47}$.

Tolosa (1997) acredita que os principais desafios enfrentados pelas políticas urbanas na mudança de conjuntura de crise e hiperinflação da década de 1970 / 1980 para a estabilização econômica iniciada nos anos 90 com o Real, foram relativos à oferta de serviços urbanos de infra-estrutura para as grandes cidades, pólos atrativos de produção e migrações, como pode-se confirmar

\title{
3.1.2. A PNDU de 1975: industrialização, autoritarismo e crise econômica
}

\begin{abstract}
"Para entender melhor essa política urbana é preciso considerar o seu contexto político e econômico. Foi concebida, formulada e implantada pelo Estado, especialmente por meio do Poder Executivo da União, já sob a égide da crise do planejamento desenvolvimentista (...) e ainda no auge do projeto de integração e segurança nacional (...). O país ainda estava impregnado pela conjuntura do sucesso econômico dos anos do milagre. (1967/73) e o governo pretendia manter o ritmo de crescimento, pressupondo que todos os segmentos sociais e todas as regiões do país seriam beneficiados" (STEINBERGER e BRUNA, 2001, p 45).
\end{abstract}

A condição de partida da primeira PNDU era de clara "subordinação" à política econômica estatal, expressa na afirmação do texto oficial de que "A Política Nacional de Desenvolvimento Urbano se insere no quadro atual da Política Nacional de Desenvolvimento Econômico e Social, como uma decorrência e uma condicionante dessa" (MINISTÉRIO DO INTERIOR, 1975, p. 73).

capital representava o limite de tolerância para com aquela política econômica. A afirmação de um projeto nacional cultivada por frações militares reforçava aquele limite na medida em que 0 desenvolvimento econômico era uma dimensão essencial (MACARINI, 2006).

${ }^{47}$ Mais sobre a política econômica e industrial desse período em BELLUZO, L.. G., e COUTINHO, R. (1982). 
A meta de desenvolvimento nacional e industrialização, que incluía pesado investimento em infra-estrutura, precisava além da energia e das estradas, mão-deobra barata e centros de consumo dos produtos nacionais, e não poderia ignorar o território como base da reprodução de suas condições e produção e acumulação capitalistas. O campo oferecia a mão-de-obra, mas já não poderia ser o suporte do novo paradigma de desenvolvimento, a exemplo do que aconteceu um século antes nos países centrais.

A transferência massiva das atividades produtivas do campo para cidade a partir da industrialização que entrava na sua fase de consolidação nacional refletiu-se claramente na mudança do perfil da taxa de ocupação urbana do país, que acontece justamente no entremeio das décadas de 1960 e 1970, passando de $36 \%$ de população urbana na década de 1950 para 56\% na década 1970.

Em 1973, as cidades foram responsáveis por $85 \%$ do Produto Interno Bruto nacional. As atividades produtivas se concentravam nas maiores cidades, num misto de urbanização e industrialização paralelas e "simbióticas" que geravam distorções e desequilíbrios na rede urbana nacional, seja na dinâmica de ocupação espacial do território, seja nas funções desempenhada pelas diferentes cidades, ou pela qualidade dos equipamentos urbanos oferecidos à população (MINISTÉRIO DO INTERIOR, 1975).

O ritmo acelerado desses processos, sem políticas urbanas e planejamentos territoriais de suporte, provocou um concentração do desenvolvimento econômico, e conseqüentemente, urbano e regional, diferenciando regiões de maior desenvolvimento industrial, a fragmentação do território nacional, com a composição de uma rede urbana fraca e hierarquizada, além da carência de infra-estrutura urbana básica (habitação, saneamento, transporte) nas cidades, para suportar o afluxo populacional que se acumulava nas periferias das grandes metrópoles nacionais e regionais em consolidação.

Essas "externalidades" do processo econômico sobre a urbanização direcionavam o poder público para "coordenação e otimização das potencialidades de múltiplas funções do espaço urbano, mediante a elaboração de uma política indutiva do desenvolvimento urbano", que seria a política urbana nacional. Uma política nacional que abordaria de forma mais direta os problemas urbanos, acabaria por se constituir 
mediante uma "concepção hierárquica de planos territoriais com amplitudes diversas, indo dos desenhos maiores dos planos nacionais e macrorregionais, até os mais limitados dos planos microrregionais e locais" (CINTRA, 1978).

No contexto da PNDU de 1975, o avanço dos problemas acumulados desde a década de 1950 passou a preocupar progressivamente o governo, assim como a crescente associação da temática urbana com a regional passou a ocupar cada vez mais espaço na agenda dos planos nacionais (STEINBERGER E BRUNA, 2001).

Até que a questão urbana entrasse na agenda como uma pauta específica, e não apenas diluída em outros planos, foram desenvolvidos ainda vários planos nacionais de desenvolvimento econômico, como o Plano Trienal (1963-1965), o PAEG (Plano de Ação Econômica do Governo) (1964-1966), o Plano Decenal (1967-1976), o PED (1968-1970), o de Metas e Bases para a Ação do Governo (MeBaG) (1970) e os Planos Nacionais de Desenvolvimento, o I PND (1972-1974) e o II PND, de 1975.

Todos esses planos perpassaram em algum nível a questão urbana, abordando problemas de concentração populacional, de desequilíbrio regional, de eixos de desenvolvimento, enfim, até se falando em "política de planejamento urbanístico" no PAEG, em "política nacional de desenvolvimento urbano no Plano Decenal" 48 e no PED em "política de desenvolvimento urbano integrado". Dentre esses, destacou-se o Plano Decenal, que não chegou a formular uma política urbana nacional, mas lançou as bases metodológicas para a criação da mesma (STEINBERGER e BRUNA, 2001) .

O que parecia estar no cerne das preocupações, além da perspectiva econômica dominante, eram políticas setoriais, de habitação e saneamento e principalmente de infra-estrutura voltadas em parte ao tratamento dos problemas intraurbanos, tais como a baixa densidade, o crescimento desordenado, a especulação

\footnotetext{
${ }^{48}$ Sobre esse o Plano Decenal em especifico "destaca-se que ele foi fundamental porque: a) agregou e sistematizou, pioneiramente, os vários temas que envolvem uma política urbana, até então abordados de uma maneira fragmentada; e $b$ ) serviu de base à formulação das políticas urbanas nacionais dos anos 70 e 80. Sem discordar desses destaques, uma releitura do documento possibilita encontrar razões mais perenes da sua importância, pela explicitação de duas posturas:a) considerar que uma política urbana vai além da problemática de funcionamento interno das cidades para ir ao encontro da problemática regional, via articulação com a rede de cidades, o que, em última análise, significava propugnar pela implantação de uma política nacional de organização territorial; e b) buscar a compatibilização de um modelo de ocupação do território com o processo econômico e social, via investimentos públicos e privados, tarefa que caberia aos organismos responsáveis pelo planejamento, coordenação e implantação da política de desenvolvimento nacional (STEINBERGER e BRUNA, 2001).
} 
imobiliária, o alto custo das estruturas urbanas, mas principalmente a necessidade de "equipar" as cidades maiores para o desenvolvimento econômico.

As ações exigiam uma envergadura de investimentos e de capacitação técnicoinstitucional que "justificavam" a elaboração de uma política em nível nacional no âmbito do planejamento urbano, tanto para atender à situação de momento e minorar as conseqüências dos desequilíbrios e desigualdades gerados pelas decisões políticas tomadas até então, como para garantir que a "função econômica" das metrópoles e regiões não fosse sobrepujada pelos problemas urbanos crescentes.

A preocupação era com a situação "irracional" dos problemas urbanos, mas que os mesmos eram passíveis de solução pelo emprego dos meios técnicos adequados. Ou seja, a ideologia da racionalidade do planejamento se alinha com o imperialismo, pois nos países centrais, afirma Serra (1991, p. 146), a situação dos subdesenvolvidos é apresentada também como fruto da irracionalidade e da incompetência administrativa.

O texto capitular da PNDU confirma que "embora com esses problemas, é a partir das metrópoles e dos grandes centros urbanos que se processa a difusão da modernização e do desenvolvimento, e é na eficácia do desempenho das funções metropolitanas que se apóia, em grande parte, o desempenho da economia e a difusão dos impulsos de modernização. Em vista disso, cumpre fixar objetivos específicos para o desenvolvimento dos sistemas urbanos que venham a ser considerados na própria elaboração das políticas e das diretrizes do desenvolvimento nacional" (MINISTÉRIO DO INTERIOR, 1975, p. 73).

Conforme a visão contida no II PND, as vultosas ações do Estado em infraestrutura urbana e regional eram necessárias às condições de instalação das indústrias e promoção do desenvolvimento econômico, que preconizava a "consolidação de uma sociedade industrial moderna e um modelo de economia competitiva", que custou muito endividamento, aumento da concentração de renda e da inflação que tiveram impactos sociais diretos na forma ocupação do espaço urbano e desenvolvimento regional nacionais.

Rolnik (1988) corrobora essa visão capitalista sobre o desenvolvimento afirmando que: "... como o próprio espaço urbano se torna campo de investimentos do 
capital, a pressão da classe capitalista sobre a ação do Estado se dará no sentido de beneficiar a maximização da rentabilidade de investimentos". A noção de Estado como poder público representativo dos interesses da multiplicidade de atores e não de apenas uma parte deles, dissipa-se em função do poder do mercado, principalmente nos países periféricos ou de economia emergente, sujeitos às determinações dos países centrais.

Na PNDU de 1975 os denominados planos diretores de desenvolvimento urbano tinham a função de promover a "preparação" das cidades para o desenvolvimento econômico industrial, sob a justificativa da sua modernização. O pósguerra gerou a demanda de substituição de importações, que acabou por impulsionar, dentre outros planos, a crença no milagre econômico nacional, mediante uma crise financeira internacional, provocada pela alta do petróleo. Bomfim (2007) relata que os economistas no período estavam em alta, ocupando cargos importantes e direcionando também as estratégias para o desenvolvimento nacional.

Foi então nesse contexto político e econômico que se desenhou a primeira política nacional de desenvolvimento urbano, coordenada pelo Ministério do Interior, com a proposta de ordenação do território nacional, observando diretrizes para os problemas regionais, metropolitanos e municipais. Apesar de vieses vários que se sobrepunham sobre a o escopo de suas proposições, e fatores diversos que limitaram a implementação de diretrizes dessa política, é considerada a primeira tentativa de ação coordenada do governo federal para se pensar o urbano dentro de uma visão "macro" de planejamento.

\subsubsection{A PNDU de 2004 e um "novo" contexto: crises econômica e urbana e ausência do Estado na virada neoliberal}

I

O primeiro estágio extensivo do capitalismo, regido pelo liberalismo, caracterizou-se pela expansão da produção a todo custo, na forma de maximização das forças produtivas. A segunda fase, intensiva, caracteriza-se pelo crença no progresso técnico como única fonte de expansão da produção. Enquanto nos países centrais nesse estágio o liberalismo dá lugar às sociais-democracias ou Estados de Bem-Estar social, com pesado investimento estatal na provisão de bens sociais, nos 
países latino-americanos - esse é o estágio da industrialização do pós- II Guerra - são os governos ditatoriais que tomam lugar, como visto anteriormente.

Tanto nos Welfare states como nos governos ditatoriais, o gasto público elevou-se nesse estágio do capitalismo intensivo (cf, Gráfico 8). No primeiro caso, incluída a provisão de serviços à coletividade e no segundo, com o "bolo" dos investimentos na acumulação, e o suficiente montante de investimento sociais somente para manter-se o discurso do "bem comum".

A resposta à crise que a expansão intervencionista do Estado provocou devido a gastos públicos elevados foi o ressurgimento do liberalismo sob nova forma, o neoliberalismo, como uma tentativa de recompor a primazia, e recuperar o âmbito da produção de mercadorias, renegando as formas social-democratas que acompanham o estágio intensivo que nega a crise estrutural e histórica do capitalismo e se volta às origens do liberalismo (DÉAK, 2004).

Gráfico 3 - Aumento dos gastos governamentais nos países desenvolvidos de 1880-1985

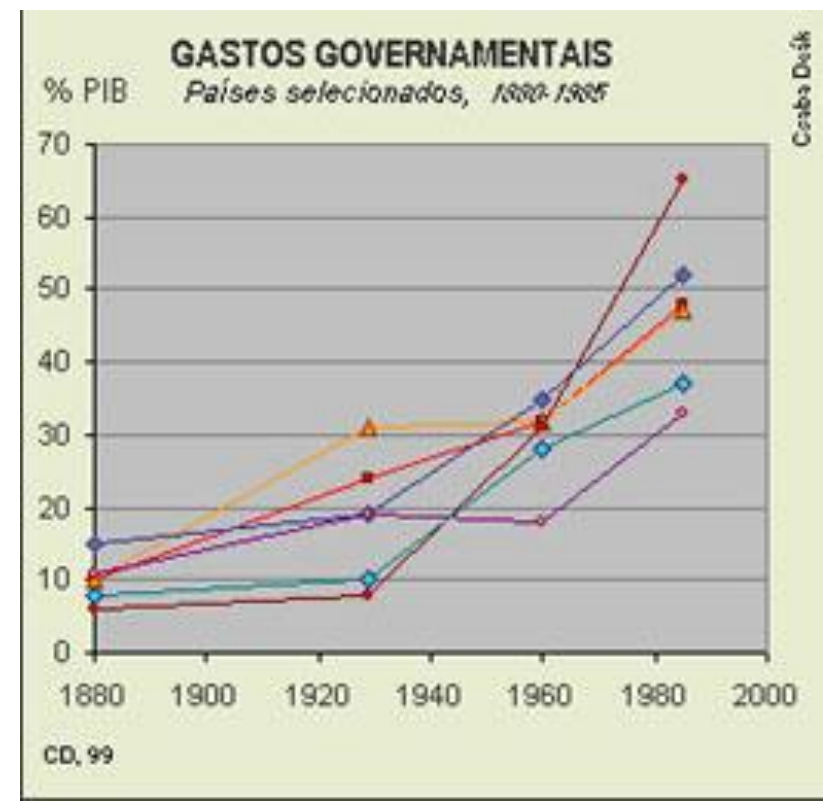

Legenda

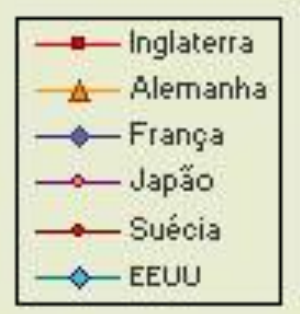

Fonte: Gráfico produzido por Csaba Déak.

As políticas neoliberais eram calcadas principalmente na redução dos gastos do Estado - o Estado mínimo - na "mercadorização", privatização e "terceirização dos serviços públicos. Tiveram lugar nos países centrais nas décadas de 1970 e 1980, e se capilarizaram nas "economias dependentes" da América Latina, como o Brasil, a partir 
da década de 1990, com amplo reforço das agências de fomento internacional, como alternativa às crises estruturais que muitos desses países estavam passando.

O movimento diretamente associado que foi fundamental para o avanço desse estágio do capitalismo, foi a globalização, ou seja, o fenômeno de "integração" mundial de mercados por meio das novas fronteiras tecnológicas de comunicação, estendendose aos mais diversos campos onde pudesse se estabelecer uma hegemonia do pensamento e da cultura do centro sobre a periferia.

Maricato (2010) caracterizou a globalização como a "ampliação internacional dos mercados revolucionada por grandes mudanças tecnológicas (movimento estrutural) combinada ao ideário neoliberal: primazia do mercado, enfraquecimento dos Estados-Nação, recuo das políticas sociais, privatizações e mercantilização dos serviços coletivos, e conseqüente aumento do desemprego e da violência".

Embora seu uso tenha se iniciado ainda na década de 1970, foi só no início deste século que o termo globalização - correspondendo grosso modo à idéia de um movimento de integração econômica de escala mundial, apoiado no desenvolvimento dos meios de comunicação e acoplado, sem maiores explicações, ao imperativo neoliberal supostamente aplicado aos maiores centros de acumulação de capital passou a ter a presença marcante no vocabulário político no Brasil.

\section{II}

Buscando alinhar-se à nova onda do capitalismo, como alternativas para a crise e uma forma de se adequar às mudanças globais surgidas na década de 1990, o País se submeteu a uma nova cartilha do poder político-econômico, o Consenso de Washington 49 "recomendado" por agentes financeiros externos para o crescimento dos países "em desenvolvimento", e seguido à risca pelos governantes do período.

O avanço do capital privado e das políticas econômicas de desenvolvimento de caráter neoliberal impõem uma política de minimização do Estado, restringindo a sua atuação enquanto agente promotor do desenvolvimento urbano, sendo este papel

\footnotetext{
${ }^{49}$ As orientações do Consenso de Washington em nada melhoraram a condição econômica do país, ao contrário, promoveram um drástico aumento da pobreza e das desigualdades sociais. Suas idéias estão hoje superadas e são criticadas pelo Dissenso de Cambridge, por Joseph Stglitz, Premio Nobel de Economia.
} 
"delegado" ao interesse privado ou à sociedade organizada. Intensificou-se a intervenção do Estado no mercado interno, mas também o incremento das desigualdades e injustiças sociais pelo desequilíbrio na distribuição de renda, refletidos diretamente no espaço intra-urbano segregado e sem uma política nacional que orientasse e reorganizasse sua instância governativa ${ }^{50}$.

A partir da década de 80 de ascensão da globalização ${ }^{51}$, derrubando-se as barreiras geográficas e econômicas pelos novos meio informacionais, e do neoliberalismo, reforçados pela cartilha do Consenso de Washington, baseando-se no laissez-faire de mercado, que preconiza a pouca intervenção do Estado e a autoregulação do mercado. Aliás, o Estado é "cooptado" mais uma vez para garantir as condições de permanência e crescimento do capital externo no mercado nacional, mediante subsídios ao interesse privado e medidas protecionistas ao mercado.

Perpetua-se a dualidade do papel do Estado, que por um lado tentava se mostra inovador, avançado, democrático, e por outro, manteve as tradicionais práticas clientelísticas, patrimonialistas, favorecendo a manutenção dos interesses privatistas e elitistas de apropriação da cidade, ou de suas áreas privilegiadas e melhor servidas. Uma contradição desoladora, mas de difícil solução, uma vez que parece inerente ao Estado esse papel duplo de garantir a acumulação do capital e intermediar os conflitos de classe.

\section{IV}

Nos anos oitenta, o processo descentralização avançou no Brasil, dando sinais de uma retomada da democratização e abertura à participação popular nos processos decisórios. A década foi marcada pelo processo de reabertura política do Estado, com o restabelecimento do pluripartidarismo. O Partido dos Trabalhadores (PT) se destacava entre as frentes de oposição, reunindo sindicalistas, intelectuais, militantes, as comunidades eclesiais de base e outros grupos para retomada do processo democrático interrompido nas décadas de 60 e 70 pela ditadura militar.

\footnotetext{
${ }^{50}$ Não por acaso, o aprofundamento de estudos sobre a "cidade ideal e a cidade real", por MARICATO, e da segregação urbana, por VILLAÇA, sintetizam o cenário que foi formado a partir de políticas excludentes e pulverizadas pelo território nacional, sem que se configurasse um planejamento axial articulado entre União, Estados e municípios para políticas e ações a serem implementadas nas cidades. Cf. Maricato (2010).
} 
Já na economia, o legado de um "milagre econômico" que não se sustentou, e de um projeto de desenvolvimento nacional calcado na substituição de importações num primeiro momento, e depois de abertura do mercado nacional ao capital estrangeiro (principalmente na década de 1990), resultou em constantes recidivas de crise nesse processo.

"Nesse cenário, os direitos sociais, econômicos e políticos, que foram conquistados através das lutas históricas dos trabalhadores, estão sendo perdidos e isso não se deve apenas, como pensam alguns ao crescimento da população urbana, mas ao fato de que esse crescimento demográfico é acompanhado pelo baixo crescimento econômico o que implica em desemprego. Na década de 1980 o crescimento brasileiro atingiu níveis negativos e ficou perto de $2 \%$ nos anos 1990 produzindo uma imensa massa de desempregados excluídos dos direitos humanos elementares". (MARICATO E SANTOS JR, 2007, p. 3)

\section{Sucessivos planos econômicos mal-sucedidos (Verão, Cruzados I e II Cruzado}

Novo), criados nas tentativas de retomada do desenvolvimento econômico geraram hiperinflação, déficit público e perda cada vez maior do poder aquisitivo do trabalhador. Em períodos mais recentes, medidas como a privatização de estatais, cortes nos gastos públicos e enxugamento da máquina estatal, já abriam o precedente para a instalação do neoliberalismo e "reducionismo econômico" do papel do Estado pela política do Estado Mínimo 52 .

Maricato e Santos Jr. (2007) dão um diagnóstico preciso desse contexto:

"A década de 1990 apresentou uma verdadeira guinada contra-reformista no Brasil. Com o início do governo Collor de Melo (1989), passando pelos dois governos de Fernando Henrique Cardoso, uma agenda de reformas econômicas estruturais de caráter neoliberal começou a ser implementada, com a adoção de políticas de liberalização econômica e a privatização de empresas estatais. Como resultado do ajuste fiscal e do rumo adotado na política econômica, o Brasil chegou ao ano 2000 como um país marcado pela contradição. Embora tendo figurado como a oitava economia do mundo o Brasil, ostenta um dos maiores índices de desigualdades sociais e de concentração de renda, com $10 \%$ dos mais ricos detendo quase metade da riqueza nacional" (MARICATO E SANTOS JR., 2007, p. 2)

\footnotetext{
52 "Um dos movimentos de resistência ao neoliberalismo no Brasil diz respeito à promoção de importante processo participativo na formulação de políticas públicas em nível nacional Além das Conferências e Conselhos Nacionais que têm ocorrido ao longo dos últimos anos como parte de sistemas institucionais, como é o caso do SUS - Sistema Único de Saúde e do SISNAMA - Sistema Nacional do Meio Ambiente, pode-se dizer que desde 2003, com o início do governo Lula, está em curso a construção de um novo modelo de gestão pública participativa." (MARICATO, E. SANTOS Jr, 2007).
} 
As escolhas políticas e econômicas ajustadas mais a uma inserção do mercado nacional no circuito do desenvolvimento financeiro-global tem seus efeitos socioeconômicos claramente sentidos sobre a desfiguração espacial das cidades, metrópoles e regiões, em processos praticamente irreversíveis de segregação urbana e assimetria de desenvolvimento regionais, restando às iniciativas de políticas urbanas nacionais um grande desafio no enfrentamento dessa crise.

\section{V}

A condição urbana nesse período associa-se aos diversos processos superpostos dos setores econômico, financeiro, político e territorial, levando a um quadro de crise urbana aguda, de serviços, de infra-estrutura, de habitação, de emprego, de violência, de degradação ambiental etc. Sobre a situação das cidades, Maricato (1996, p. 7, passim) bem expressa esse quadro em seu texto:

"De fato, as condições de vida nas grandes cidades, principalmente nas metrópoles, têm se deteriorado a olhos vistos configurando o que podemos chamar de crise urbana. De espaço de mobilidade social e lugar de acesso à diversidade cultural, melhores oportunidades de emprego e qualidade de vida, elas têm se tornado aglomerações, em grande parte depósito de pessoas, marcadas pela fragmentação, dualização, violência, poluição e degradação ambiental".

Hoje a "crise urbana" se expressa por seus números: déficit habitacional altíssimo, acompanhado não só de uma insuficiência numérica, mas de qualidade técnica e locacional das habitações produzidas, com ou sem apoio governamental; cobertura insuficiente de serviços de água e esgoto, acompanhado do acúmulo progressivo de resíduos nos aterros mal localizados, gerando problemas ambientais, de saúde, e de degradação social, pelos que deles vivem e deles se alimentam e tiram seu sustento.

Gráfico 4 - Índices urbanos gerais brasileiros, 2008.

INDICES URBANOS GERAIS BRASILEIROS EM 2008

\begin{tabular}{|l|l|}
\hline População & 180 milhões $^{*}$ \\
\hline Número de municípios & 5.561 \\
\hline Déficit habitacional & 7,2 milhões de moradias \\
\hline Água potável & 45 milhões de pessoas sem acesso \\
\hline Esgoto & 83 milhões de pessoas sem sistema \\
\hline Coleta de lixo & 12 milhões de pessoas sem acesso \\
\hline
\end{tabular}

Fonte: Ministério das Cidades *Fonte: IBGE (Conselho das Cidades: Um Exercício de Gestão Democrática, Ministério das Cidades, Brasília, 2006). 
A sanha capitalista tem seu preço. E as políticas urbanas não têm conseguido dar respostas à altura da necessidade de superação dos passivos do processo capitalista. No contexto nacional, desde a explosão urbana de meados do século, não há políticas integradas, nem planejamento continuado que atendam a contento ou que pelo menos atenuem a curva crescente desses processos. É o que conclui Maricato (1996) na continuação do texto:

\begin{abstract}
"Ao mesmo tempo, em termos institucionais, a política urbana nunca esteve entre as prioridades do Estado brasileiro mesmo na única oportunidade que mereceu uma formulação holística, durante o Regime Militar. Os sucessivos governos nunca tiveram um projeto estratégico para as cidades brasileiras envolvendo, de forma articulada, as intervenções no campo da regulação do solo urbano, da habitação, do saneamento ambiental, e da mobilidade e do transporte público. Sempre de forma fragmentada e subordinada à lógica de favorecimento que caracterizava a relação intergovernamental, as políticas urbanas foram de responsabilidade de diferentes órgãos federais".
\end{abstract}

Essa é a face da crise urbana, a realidade que acomete as cidades, as regiões, as metrópoles. Na cidade, a violência, a pobreza, a exclusão da maioria em contraste com a riqueza, a ostentação e luxo de uma minoria. Na metrópole, os governos querem desfrutar do status "metropolitano" ou "megalopolitano", mas quem assume o ônus? Nas regiões, as disputas por "atratividades" para o capital se perpetuam, e as forças a políticas regionais de reorganizam em coalizões cada vez mais fortes. Por outro lado, os movimentos de reforma urbana (apoiados por um grande grupo de intelectuais, profissionais, militantes etc) introduziram a luta por uma "socialização cada vez maior da função social da propriedade urbana".

"A negação do direito à cidade se expressa na irregularidade fundiária, no déficit habitacional e na habitação inadequada, na precariedade e deficiência do saneamento ambiental, na baixa mobilidade e qualidade do transporte coletivo e na degradação ambiental. Paralelamente, as camadas mais ricas continuam acumulando cada vez mais e podem usufruir um padrão de consumo de luxo exagerado. É no contexto dessa contradição expressa na segregação urbana que explode a violência e cresce o poder do crime organizado na cidade. Os paradigmas hegemônicos do urbanismo e do planejamento urbano têm revelado seus limites e não estão conseguindo dar respostas aos problemas contemporâneos das grandes cidades" (MARICATO, 1996).

É o descumprimento claro da função social da cidade e da propriedade urbana. Isso na visão marxista é o reflexo da luta de classes que ocorre no espaço urbano, 
onde a produção e reprodução desse espaço está condicionada à geração de mais valia aos capitalistas, e a massa de proletariados vê-se cada vez mais desprivilegiada e alijada de seu direito à cidade, ao espaço por eles também socialmente construído.

Por isso o marco lógico da nova PNDU ${ }^{53}$ parte do reconhecimento dessa crise urbana e tem como meta principal o cumprimento da função social da cidade e da propriedade, que em tese, deve se contrapor à práticas de fragmentação territorial, exclusão e segregação urbana, alta concentração de renda, limitações do poder público competente lidar com os problemas acarretados e planejamento urbano ineficaz, e incluir na sua noção de desenvolvimento urbano não somente as dimensões materiais - traduzidos no provimento da infra necessária à terra urbanizada - e imateriais desse desenvolvimento, com atenção à qualidade de vida nos espaços urbanos produzidos.

No plano regional (menos presente, mas mencionado), a PNDU busca condições de equilíbrio igualdades de crescimento econômico entre cidades e regiões no Brasil, o que passa tanto pela reconstrução de um projeto nacional de Estado, que proporcione os corretos incentivos e meios para o crescimento das regiões mais atrasadas, como também pelo aproveitamento de processos endógenos (à região) que forneçam subsídios para as políticas de crescimento a serem criadas e implementadas.

Num quadro sintético da situação socioeconômico e político brasileiro das últimas décadas, pode-se dizer que: 1) a década de setenta foi marcada pelo processo lento e gradual de abertura política, planos nacionais de desenvolvimento e um crescimento urbano acelerado; 2) nos anos oitenta, cresce o movimento pela democratização do Estado, bem como a recessão e desemprego com inflação galopante, mas desaceleração do inchaço populacional urbano; 3) de noventa em diante, tem-se a descentralização político-administrativa, o neoliberalismo econômico e a agudização da crise social e urbana.

\footnotetext{
${ }^{53}$ Como já visto, a criação de uma nova política urbana no âmbito federal dá-se somente com a nova Constituição de 1988. A nova Carta Constitucional não só determinou a criação de uma política de desenvolvimento urbano (com diretrizes fixadas em lei), a ser executada pelos municípios, como também traz a exigência do cumprimento das funções sociais da cidade e da propriedade urbana, que teriam no plano diretor seu principal instrumento de apoio (BRASIL, 1988). Cf. BRASIL. Constituição (1988). Constituição da República Federativa do Brasil, Brasília, DF, Senado, 1988.
} 
A questão é: as PNDUs, mesmo em contextos econômicos, políticos e urbanos diferenciados, conseguiram influenciar os rumos do desenvolvimento urbano em cada período? Que cidades "produziram"? Que regiões impactaram? A que interesses atenderam? Essas e outras perguntas podem encontrar indícios de repostas ou constatações ao longo das análises comparativas das PNDUs.

\subsubsection{Considerações: a influência dos contextos nas PNDUs}

Ao longo da história nacional observa-se que os movimentos de centralização e descentralização, de ditadura ou democracia, de oligarquias ou burocracias no poder, claramente se refletiram na forma de gestão urbana, e conseqüentemente, na formulação da política urbana.

A política urbana, tendo um caráter essencialmente de ordenação do desenvolvimento e expansão urbana, mantém uma (inter) dependência dos contextos político-econômico, que acabam por determinar vários aspectos dessas proposições, desde seu processo decisório à engenharia institucional para implementação de suas diretrizes. Isso se configura, por exemplo, na abertura ou não à participação da sociedade nos processos de planejamento urbano, na capacidade institucional de atendimento às demandas dos problemas urbanos e na forma de intervenção do Estado sobre as políticas urbanas.

O fato de estar-se sob uma ditadura militar em 1975 claramente denotava a exclusão da sociedade da participação do processo decisório em função do autoritarismo e ingerência do governo federal na definição das políticas. Como visto, a tônica de centralização e autoritarismo da ditadura permeou a esfera pública durante esses anos e cerceou toda e qualquer possibilidade de participação popular efetiva nas políticas públicas. No entanto, "os donos do poder", as oligarquias regionais, permaneciam como sub-centros do poder central, influenciando e favorecendo-se da estrutura patrimonialista e clientelista do Estado para se manter no centro das decisões políticas.

A formulação de políticas e o planejamento estavam a cargo de uma tecnocracia que se baseava numa visão setorizada de cidade, dividida em habitação, saneamento e transportes. Para Souza (2004, p.141), que participou como "técnica" no processo de elaboração dessa PNDU, a grande dificuldade apontada encontrada foi de 
cunho político e também metodológico. Político porque, na opinião da autora, o essencial da política, que estava subjacente ao seu significado, que era assumir a sociedade e o espaço como uma totalidade, não foi possível pela estreiteza da compreensão teórica sobre a urbanização por parte dos economistas no poder, que apresentavam uma visão contábil da sociedade, e por parte dos donos do poder, pela avidez dos interesses que representavam e que uma política urbana mais orgânica viria confrontar.

Ao longo da história nacional, viu-se muitas vezes o Estado comandado pelas forças produtivas (indústria) e posteriormente financeiras (bancos) do mercado, e a possibilidade de um Estado de bem-estar social cada vez mais ofuscada em função das demandas mercadológicas. O rumo equivocado das políticas para o desenvolvimento urbano, ou mesmo a ausência dessas, permitiu que fossem criadas "outras políticas", não oficiais, de ocupação do território ${ }^{54}$, tacitamente admitidas como forma de compensação aos "excluídos" frente ao privilégio dado ao mercado imobiliário e à elite minoritária no financiamento das estruturas e superestruturas urbanas ${ }^{55}$.

Scherer (1995, p. 64) afirma que mesmo diante da volta dos regimes democráticos na América Latina, com entendimento da importância da correlação entre as forças políticas e econômicas, com diferentes lógicas do capital, não trouxe um igual rebatimento na capacidade de formulação de projetos. Para autora, no caso brasileiro, as condições políticas sob as quais se desenvolveu aqui a prática do planejamento foram marcadas pela reprodução de modelos, assumindo o planejamento uma característica redistributiva, ainda que com critérios e prioridades variáveis, segundo os grupos políticos no poder.

Para Steinberger e Bruna (2001), na I PNDU o processo de urbanização foi considerado como determinado e não como determinante, porquanto o espaço urbano aparecia como palco de problemas e as ações da política urbana, e deveriam corrigir os efeitos nocivos do modelo de crescimento econômico adotado, com características centralizadoras, concentradoras e excludentes. Portanto, a política urbana tinha função "compensatória e corretiva". Surgiu como uma política de atendimento a carências, isto é, anti-déficit de serviços coletivos. Essa postura também visava responder a um

\footnotetext{
${ }^{54}$ MARICATO (2010). Mais sobre as (não) políticas da ilegalidade urbana, ou a "a cidade informal" podem ser encontradas em várias outras obras de Maricato.

${ }^{55} \mathrm{O}$ termo superestruturas urbanas foi emprestado de Csaba Déak.
} 
começo de perda de poder do partido do governo da ditadura (Arena) em relação à oposição (MDB), especialmente em alguns dos maiores aglomerados urbanos do país, as regiões metropolitanas.

No atual contexto, o Ministério das Cidades (2004a, p. 29), reconhece que Estados Nacionais foram e continuam sendo desafiados por forças poderosas que não são apenas externas, uma vez que estão presentes e articulam-se internamente também. Embora condenados a desempenhar papel secundário na etapa que se abre, o Estado Nacional "constitui arena e instrumento indispensável de qualquer projeto que pretenda preservar a soberania política, a cultura própria e a possibilidade de construir uma nação que escolha seus próprios caminhos".

Na política de 2004 o contexto é um tanto dúbio, porquanto ainda se observa uma forte pressão do mercado interno e externo sobre o Estado, e este ao mesmo tempo mantém um discurso constante de democratização da gestão e participação da sociedade nos processos decisórios, herança dos movimentos de luta pela Reforma Urbana dos anos 80, como se vê na assertiva do Ministério das Cidades:

\begin{abstract}
"neste âmbito, ressaltam-se os atores da sociedade civil brasileira atuantes no campo das políticas urbanas, sua mobilização e organização como atores coletivos, sua atuação em espaços públicos e em espaços institucionais, seu papel na retematização do urbano a partir dos anos 80 , especialmente no que se refere à construção da agenda de reforma urbana. Entre outros pilares, a agenda de reforma urbana assenta-se em pressupostos de democratização da gestão das cidades - mediante a participação cidadã nos processos decisórios - e na perspectiva de inclusão delineada pelo reconhecimento do direito à moradia e à cidade (MINITÉRIO DAS CIDADES, 2004a).
\end{abstract}

E ainda sobre a reforma, assume o discurso de combate às práticas tradicionais sobre as quais se assentaram o planejamento urbano das últimas décadas - incluída a visão centralizada, tecnicista e economicamente enviesada da PNDU de 1975 - na contra-mão da universalização social do direito à propriedade e à cidade para os excluídos de outrora, periféricos de hoje e, quiçá, cidadãos do amanhã.

"Construída nos domínios da sociedade civil, pela articulação de atores coletivos heterogêneos quanto a suas bases organizativas, a plataforma de reforma urbana desafia as matrizes tradicionais da cultura política brasileira e os modelos tradicionais de planejamento urbano, ou seja, desafia práticas e representações sociais. Assumem-se premissas, portanto, de constituição de novos atores coletivos da sociedade civil inscritos no campo das políticas urbanas que logram influir decisivamente 
nos seus marcos legais e instrumentos no âmbito federal (na Constituição Federal e no Estatuto da Cidade), assim como no âmbito local. Sua influência se expressa no sentido da democratização das políticas urbanas - sobretudo por meio da criação de instâncias de participação cidadã - e da cunhagem de possibilidades de justiça e inclusão socioespaciais através do emprego dos "novos" instrumentos normativos. (MINISTÉRIO DAS CIDADES, 2004a),

Também decorrente dos debates internacionais da globalização, de valorização da escala local e supressão dos Estados Nacionais, e nacionais pela nova condição do município como ente federado, e sua competência como agente promotor e executor da política de desenvolvimento urbano e campo privilegiado de experimentações das "novas" relações e instrumentos que se propõe a partir de uma construção participativa, o Ministério das Cidades entende que:

"A esfera local afirma-se como um terreno privilegiado de concretização desses avanços e experimentações que se tecem nas interseções entre o poder público e a sociedade, implicando, no caso das políticas urbanas, o delineamento de possibilidades de renovação nos seus princípios norteadores, conteúdos, instrumentos, arranjos institucionais e formas democráticas de gestão" (MINISTÉRIO DAS CIDADES, 2004a).

Esse é o contexto que se configura no desenvolvimento da atual PNDU, em processo de elaboração desde 2003. Sob o mote da "gestão urbana democrática", a sistemática empreendida para incorporação de proposições e formulações advindas de uma base ampla de discussões por vários setores da sociedade abre precedentes para que a diversidade de grupos sociais tenha mais que um direito a voz - o que, considerando-se o contexto brasileiro anterior já seria significativo - possa também deliberar sobre as decisões políticas a serem tomadas sobre os rumos do desenvolvimento urbano.

Habitação, transporte e saneamento são determinados como investimentos básicos do poder público para garantir condições mínimas de vida à população de excluídos fundiários, insistentemente direcionados para as áreas de alta renda, fomentando o processo de expulsão dos desfavorecidos da cidade legal para as periferias urbanas, a cidade real.

Mas por outro lado, a força do agente privado sobre o mercado das terras, infra-estrutura e equipamentos urbanos, mantém-se ainda com grande poder de influência e interferência sobre as políticas urbanas, especificamente na apropriação privada da terra urbanizada. Essa é outra faceta da influência da economia sobre o 
urbano, da alta concentração de renda e fundiária e exclusão territorial. Enquanto o poder público desempenha papel dúbio na tentativa de garantir a permanência e atratividade do capital externo nas cidades, cresce a massa de excluídos do direito à cidade, dos que vivem na ilegalidade dos interstícios urbanos, sem terra urbanizada.

A segregação sócio-espacial urbana, bem como a exclusão, a violência, a falta de moradia etc, se agrava à medida que os interesses do capital privado, vis-à-vis às determinações dos agentes externos para reformas pró-mercado, encontram no poder público, em qualquer escala, um aliado, parceiro ou patrocinador para a consecução de seus objetivos, na mais perfeita ordem do Estado neoliberal.

No contexto urbano, o financiamento de projetos urbanos pelo Governo Federal e por grande bancos internacionais como BIRD (Banco Internacional para Recuperação do Desenvolvimento, uma parte do Banco Mundial), BID (Banco Intermericano de Desenvolvimento), Citibank e outros provoca uma corrida de adequação do planejamento urbano às demandas desse agentes, seguindo modelos propostos para a preparação das cidades para o mercado global. Como dito por Harvey (1996), o "empresariamento urbano" gera a competição entre cidades, numa disputa por atratividade de indústrias e visibilidade mundial. É o movimento das chamadas cidades mundiais.

Entra em pauta a questão das escalas, tema emergente na agenda da globalização e do neoliberalismo, que também pressupõe a supressão da escala nacional, dos projetos de Estado-Nação, mas tem nas metrópoles e megalópes pontos cruciais nos projetos de hegemonia do capital, como o foi nas décadas passadas.

\subsection{QUESTÃO TERRITORIAL, REGIONAL, METROPOLITANA}

\subsubsection{Contextos e debates: planejamento regional, teoria dos pólos de desenvolvimento e a metropolização no Brasil}

"O que é uma política urbana definida a nível federal? Refere-se a ocorrências se passando no nível do interior das aglomerações? Ou deve se referir aos espaços existentes entre as aglomerações? Ou, em outras palavras, trata dos espaços interurbanos ou intra-urbanos? (...) uma política urbana a nível federal sempre encontra alguma perplexidade quando trata das diversas esferas de poder: federal, estadual e municipal. Quando se refere a grandes aglomerações denominadas regiões metropolitanas, as dificuldades são ainda maiores" (SERRA, 1991, p. 24). 
O acelerado processo de evolução econômica que se deu no pós-guerra e o agravamento dos desequilíbrios regionais de diversos países do centro, foram fatores responsáveis pela onda de planejamentos regionais nesse período (FRIEDMAN, 1966, citado por FERNANDES E MEDEIROS, 1978).

Como várias dessas "ondas" internacionais encontram seu lugar nos países em transição - embora com conjunturas diferenciadas - com o planejamento regional no Brasil não foi diferente, mas certamente envolvendo questões específicas de um contexto periférico da economia: "A questão básica para os países subdesenvolvidos é atingir uma alta taxa de crescimento econômico em um espaço nacional pouco articulado, pouco integrado, e cujos recurso são ineficientes" (FERNANDES e MEDEIROS, 1978, p. 51).

Dada a interferência direta dos processos econômicos sobre o território, o papel do planejamento regional no processo de desenvolvimento nacional acaba por se tornar função das transformações espaciais acarretadas pelo desenvolvimento econômico (FRIEDMAN, 1966) Para esse autor, o grau de importância dado ao planejamento urbano varia de acordo com o estágio de desenvolvimento por que passa o país.

Por exemplo, em países cuja economia estaria em fase de transição, como o Brasil, México, Venezuela, à época de suas industrializações (pós-guerra), o planejamento regional teve uma importância crítica nesse processo, onde a ênfase das políticas estaria voltada à "criação e de uma organização espacial capaz de sustentar a transição para a industrialização" (FRIEDMAN, 1966).

Mas mais do que isso. Devido ao curto intervalo de tempo em que essas transformações se processam no espaço pelas economias em transição, o que seria característico do estágio de "industrialização plena" dos países do centro (Estados Unidos, França, Inglaterra) - segundo a classificação de Friedman - nos países da periferia em "transição", algumas dessas características se adiantam e ocorrem concomitantemente ao processo em curso, provocando externalidades como: "elevado grau de dependência externa, deseconomias de aglomeração, marginalidade urbana, má alocação de recursos e investimentos públicos, etc. (FERNANDES e MEDEIROS, 1978, p. 53). 
Segundo Stür (1972), os fenômenos regionais comuns aos países da América Latina têm na sua base "as disparidades", assimetrias e desequilíbrio das redes e sistema urbano-regionais: disparidades inter-regionais com relação à renda, com subaproveitamente de recursos potenciais; disparidades interurbanas pelos altos índices de urbanização, mas com padrões assimétricos, com concentração em torno de alguns centros); disparidades urbano-rurais com mecanização - e pauperização - do campo desvinculada dos interesses da região; disparidades internacionais pela concentração do desenvolvimento nacional em regiões-pólo, e dificuldades de integração nacional, ou mesmo, internacional.

O desafio do planejamento regional, dentro do contexto do desenvolvimento nacional de uma economia periférica - no que o Brasil se enquadra - caracterizou-se pelo enfrentamento dessas distorções e assimetrias internas. O quadro a ser enfrentado resumia-se por:

(i) "concentração excessiva de atividades e de população em algumas áreas ou pontos do espaço nacional, gerando deseconomias de aglomeração e deterioração da qualidade de vida;

(ii) estagnação ou declínio econômico de regiões que, no passado, haviam experimentado relativo surto de desenvolvimento industrial;

(iii) mal ou indevido aproveitamento da dotação da dotação de recursos naturais em algumas regiões;

(iv) dificuldades à integração nacional e mesmo internacional" (FERNANDES E MEDEIROS, 1978, p. 58)

A política de desenvolvimento regional no Brasil implicou em certo tipo de ação sobre a teoria dos "pólos de desenvolvimento". Segundo essa teoria, verifica-se a tendência à aglomeração da população, das adaptações do espaço e das atividades econômicas, assim como a constatação do papel histórico das cidades na produção nacional, gerando concentração, aglomeração, investimentos numa dada localidade que pode impactar sobre sua região (Serra, 1991, p. 23). Segundo o autor no Brasil com freqüência tem-se a noção sobre difusão de hábitos de consumo ou aspectos culturais, como se o pólo fosse uma 'mancha de óleo', de onde fosse possível irradiar a 'modernização'. 
Essas políticas trazem também o pressuposto da possibilidade e da conveniência da ação do Estado, ou melhor, do Estado 'como um Estado instrumental que se transformou no sujeito da história, com a organização social do território posta como seu predicado (Gun, 1985)'” O Estado brasileiro dessa forma pretenderia, utilizando um conjunto de políticas, promover o desenvolvimento por meio da concentração dos investimentos públicos e privados em determinados pólos. Por isso a geopolítica traçou estratégias internas para o País como ocupação territorial, abertura de estradas, provisão de infra-estrutura e energia para as cidades e regiões de maior atratividade industrial, e externas, de projeção nacional perante a América Latina.

\section{II}

Como parte também dos dilemas regionais e urbanos, a metropolização como processo e as metrópoles como novo arranjos institucionais e territoriais, são uma categoria à parte que, como a região e as cidades, têm na dinâmica do modo de vida e da produção aspectos mais determinantes sobre suas condições do que o próprio aspecto territorial ${ }^{56}$.

"A metropolização configura o expressivo adensamento populacional em alguns pontos do território pela ação concentradora da dinâmica da economia" (MOURA, 2008, p. 103). A ocupação das periferias urbanas por migrantes (o exército industrial de reserva no dizeres de OLIVEIRA (1982) e excluídos do processo de acumulação - e pela concentração e mercadorização fundiária - reduziu cada vez mais os interstícios interurbanos, provocando o fenômeno da conurbação em algumas cidades principais.

Com a industrialização, esses pontos ou manchas de adensamento começam a se delinear de forma mais nítida e concentrada, com São e Rio de Janeiro apresentando-se essas cidades como os "pólos" principais dessa dinâmica. De fato, em 1970, as aglomerações de São Paulo e Rio detinham juntas cerca de $16 \%$ do total da população brasileira, e em 2000, 30 anos depois, mantiveram-se ainda com 13\%, sendo que somente São Paulo detinha 10, 5\% (MOURA, 2008.)

O processo de metropolização começava a se intensificar, e em 1973 foram criadas as nove regiões metropolitanas, entre elas, a de São Paulo (Rio de Janeiro foi

\footnotetext{
56 A definição de "Região metropolitana" utilizada pelo IBGE (1973-1999) é de "um agrupamento de municípios limítrofes, instituída por legislação, com vistas ao planejamento e execução de funções públicas de interesse comum."
} 
instituída logo depois), que se consolidava como metrópole nacional, atraindo populações de várias partes do país, bem como metrópoles regionais (Belo Horizonte, Salvador, Recife etc), que canalizavam um fluxo populacional advindo principalmente das cidades do interior de cada região.

O eixo Rio-São Paulo era o centro - a "core region" - e exercia forte "pressão negativa" no sentido de atração populacional, mas também impactava na dinamização de outras regiões próximas, como Belo Horizonte e Porto Alegre, enquanto as demais metrópoles precisavam de uma atenção maior do governo federal para alavancarem seu desenvolvimento.

De fato, via-se um rápido avanço da industrialização sobre as cidades, decorrente das mudanças ocorridas ao longo do século $X X$, de passagem de uma economia de base agro-exportadora para uma economia dinâmica de base industrial. $O$ impacto dessas mudanças no espaço foi sentido diretamente na forma de ocupação do território, na dinamização de algumas regiões, dentro do modelo centro-periferia, típico do modelo da fase de substituição de importações.

O pesado investimento estatal em infra-estrutura e os incentivos fiscais, baixos salários, e atratividades de recursos naturais de alguns estados intencionava provocar mudanças no quadro tradicional de concentração industrial no sudeste e expandir novas fronteiras econômicas para outras regiões, com as economias de aglomeração, impactando a dinâmica regional, e conseqüentemente, a dinâmica de urbanização nacional (SOUZA, 2004). Segundo a autora, eram características da urbanização brasileira na década de 70 :

- Importância crescente das cidades médias (250 a 500 mil habitantes);

- Importância crescente das cidades grandes (500mil a 2 milhões de habitantes) implicando em um processo de metropolização crescente;

- Urbanização dinâmica;

- A dinâmica da configuração territorial obedecendo às leis da prioridade da localização dos investimentos;

- Atração e absorção da mão-de-obra pelos pólos mais dinâmicos do país;

- Cerca de $50 \%$ do crescimento urbano era devido às migrações internas (entre cidades e regiões), mais do que as migrações rurais;

- Amplas e crescentes disparidades inter e intra-regionais, com: o eixo RioSão Paulo como núcleo central, com rede urbana bem consolidada; a região Nordeste com boa infra-estrutura, mas sem base econômica; e as regiões norte e centro-oeste como periferias regionais, ainda com parca ocupação. 
A região Sudeste apresentava um alto índice de urbanização, enquanto na região Norte havia um movimento inverso. Nas regiões Sul e Nordeste, com menor concentração de atividades econômicas industriais, ainda incipientes, mas mantendo ainda uma base agrícola considerável, a relação de população urbana e rural apresenta-se relativamente equilibrada. Na centro-oeste, nessa década há um pico de urbanização, com as economias de aglomeração e o deslocamento das fronteiras agrícolas para o interior do país.

O mapa abaixo mostra como estava a dinâmica regional em função das atividades econômicas.

Mapa 2 - Tipos de regiões segundo interações espaciais - PNDU de 1975

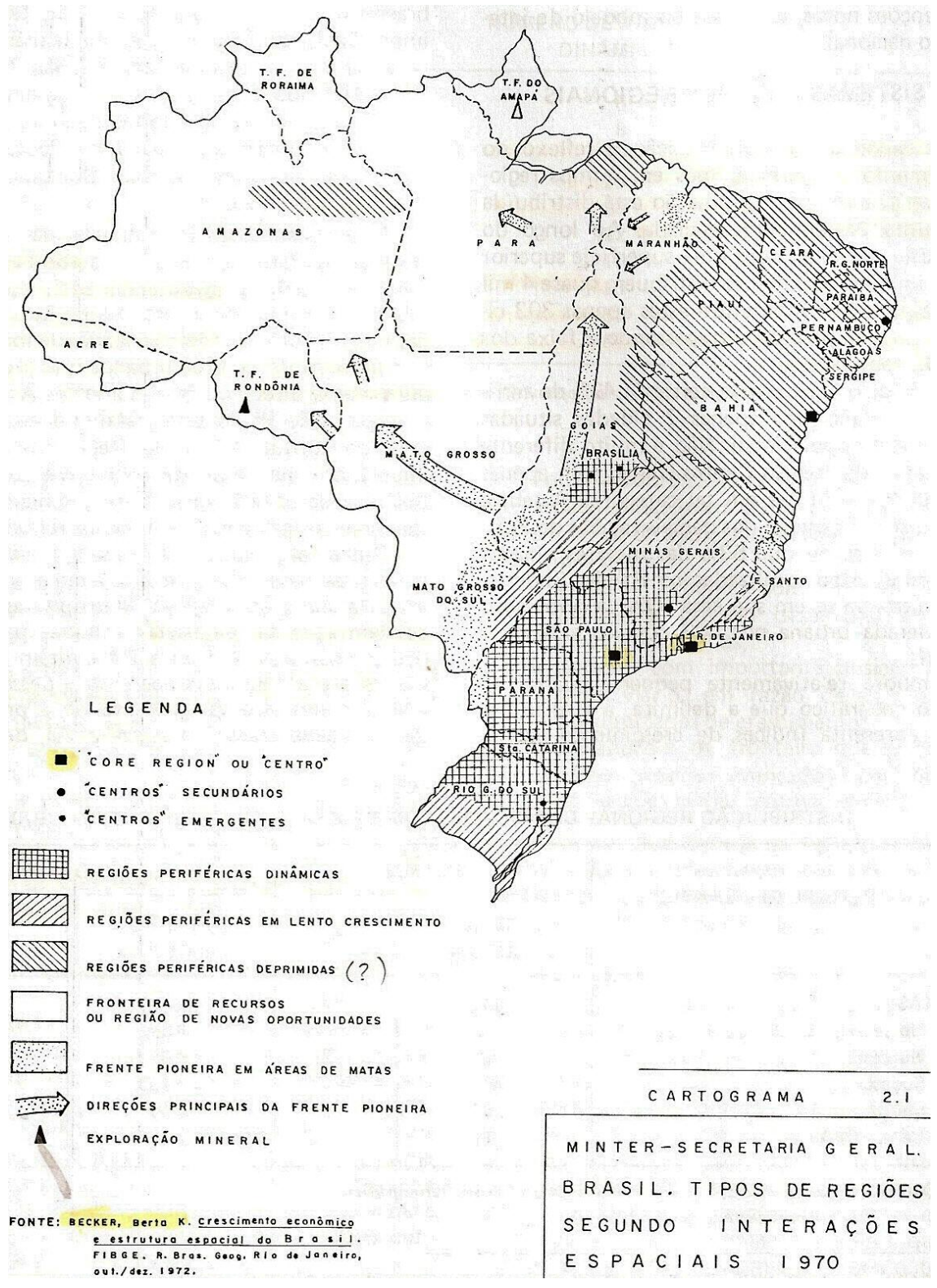

Fonte: Ministério do Interior, 1975 (Fonte do mapa referenciado no próprio mapa). 
Em função dessas dinâmicas, e ainda critérios de importância sócioeconômica, área territorial de influência, e subordinação de outros núcleos urbanos, a rede urbana brasileira estava classificada em:

- Grande metrópole nacional (São Paulo)

- Metrópole nacional (Rio de Janeiro)

- Centros metropolitanos regionais: Recife, Belo Horizonte, Salvador e Porto Alegre

- Centros macrorregionais: Curitiba, Fortaleza, Belém e Goiânia

Pela observação dessas áreas no mapa e suas áreas de influências, pode-se dizer que o desenvolvimento nacional do País concentrava-se na faixa litorânea a oeste, na costa do Atlântico, e inegavelmente na Região Sudeste, em detrimento do interior do território, principalmente Centro-oeste (nessa época ainda "fronteira de desenvolvimento" que começa a ser explorada) e Região Amazônica, parcamente desenvolvidos, ou com áreas ainda sequer ocupadas).

Como já visto, a metropolização crescente e as grandes disparidades inter e intra-regionais colocavam-se como "justificativas" para a ação centralizadora do Estado como forma de prover as soluções para os problemas urbanos. Devido ao acelerado processo de urbanização, viu-se a necessidade de se criar "pólos de desenvolvimento" secundários visando a uma descentralização que permitisse 0 aproveitamento do potencial econômico e de mão de obra das demais áreas (BOMFIM, 2007, p. 319). Nesse aspecto, as cidades médias tiveram um papel relevante dentro da estratégia de planejamento do espaço urbano-regional da década de 1970.

\section{III}

Apesar das metrópoles serem o centro primeiro de investimentos e migrações, na década de 70 tem-se um aquiescimento (não estagnação) desse incremento populacional e econômico, redirecionando o fluxo migratório do núcleo para outras cidades periféricas da metrópole, na faixa de 250 mil a 500 mil habitantes (STEINBERGER e BRUNA, 2001).

Enquanto as metrópoles nacionais e as metrópoles regionais cumpriam seu papel relevante na dinâmica interna da produção e, conseqüentemente, sofriam as decorrências da insuficiência de suporte para a instalação do contingente populacional que se instalavam em suas periferias, outros núcleos começavam a se tornar atrativos 
e cumprir papéis secundários no circuito econômico nacional, chegando em 1980, a observar-se uma tendência de crescimento de população em centros de médio porte. (Idem).

A necessidade de atenção sobre as cidades de médio porte, como centros de apoio à rede metropolitana, já era conjeturada nos planos econômicos estudos que precederam a PNDU de 1975, sob o discurso da necessidade de dinamização de outros centros regionais e desconcentração metropolitanas, apesar de posteriormente reforçar-se a concentração em ambos os sentidos, econômico e territorial.

As teorias de localização, dos pólos de crescimento e desenvolvimento, e as economias e deseconomias de aglomeração têm sua parte explicativa no processo de ascensão dos subcentros econômicos que se formaram a partir das cidades médias. As teorias de localização levavam em consideração "custo de transporte; b) forças de aglomeração; e c) forças de desaglomeração" (WEBER, 1929). Na teoria dos pólos de crescimento e desenvolvimento de Perroux (1967): “a) o crescimento é localizado, isto é, não disseminado no espaço ou no aparelho produtivo; b) o crescimento é forçosamente desequilibrado; e c) a interdependência técnica é um fator a se destacar na transmissão do conhecimento".

Os efeitos da aglomeração dizem respeito às relações de uma cadeia produtiva, o que um certo centro ou pólo pode fornecer ou proporcionar em termos de condições para instalação de um indústria ou pólo de desenvolvimento (infra-estrutura, mão-deobra, mercado consumidor), enquanto a deseconomia possibilita a transferência de atividades, principalmente em se falando de atividades industriais, de pólos mais concorridos ou "saturados" em alguns de seus fatores para centros de menor porte $e^{57}$.

Nesses contextos, as metrópoles passam da concentração à desconcentração em certa medida, enquanto as cidades médias se colocam como pólos secundários de apoio à dinamização da economia. Steinberger e Bruna ressaltam a contradição do discurso da política urbana (PNDU), que preconizava a descontração espacial e equilíbrio da rede de cidades, com a política econômica (II PND), que tinha como meta concentrar para aumentar a eficiência econômica da industrialização:

\footnotetext{
${ }^{57}$ Ainda as economias de escala e de urbanização completam esse quadro.
} 
"Além disso, a política urbana postulava desconcentração geográfica, mas a política econômica buscava um novo patamar de substituição de importações, com ênfase nos setores de bens de capital e insumos básicos, que possuíam caráter nitidamente reconcentrador em termos espaciais. Isso equivale a reconhecer uma contradição entre os discursos das políticas enfeixadas no mesmo plano de governo." (STEINBERGER E BRUNA, 2001, p. 46).

A solução da contradição estaria justamente no investimento nas cidades médias para conciliação entre as duas visões: "Para conciliar esse conflito o plano propunha favorecer a criação de pólos secundários, as cidades de porte médio, que se aproveitariam das vantagens das aglomerações existentes, ao mesmo tempo que serviriam de base a uma estruturação de apoio à formação de um sistema urbano nacional mais equilibrado" (Idem).

Apesar das análises posteriores apontarem relativo crescimento das cidades médias ao longo dos anos 1990, o desequilíbrio da rede de cidades e a assimetria e heterogeneidade regional, continuou a ser uma realidade característica do sistema urbano-regional, e o é até hoje.

\section{IV}

Industrialização e a urbanização são processos intrinsecamente relacionados que se desdobram em um quadro claro hoje: as condições de crescimento urbano e econômico diferem bastante no Brasil entre regiões e dentro delas, em níveis estaduais e municipais e impactam diretamente na capacidade de provisão de espaço profícuos não somente para o desenvolvimento de uma dada região segundo os padrões externos, mas sobretudo para a integração interna, intra-urbana, de uma massa (mãode-obra, migrantes, suburbanos, excluídos) que cresce e se aglutina à margem de qualquer processo de desenvolvimento regional ou intra-urbano.

Historicamente, pode-se dizer que esse abissal desequilíbrio regional (tanto de dinamização econômica quanto de ocupação territorial) no Brasil é herdado desde o período agrícola exportador nacional, onde as regiões produtoras concentravam maiores investimentos do Estado e atraíam maior contingente populacional ${ }^{58}$.

\footnotetext{
${ }^{58}$ Como visto, essa lógica se reproduziu e se ampliou com a entrada das indústrias no mercado nacional, bem como das atividades produtivas em escala que as acompanharam, trazendo também a modernização/mecanização do campo, que geraram outras dinâmica produtivas no campo, mesmo à margem ou complementares às atividades industriais, essencialmente urbanas.
} 
As diferenças regionais são latentes principalmente entre as regiões pobres do norte (Norte e Nordeste) e as regiões ricas do sul (Sudeste, Centro-oeste e Sul). Segundo o trabalho de Da Mata (2005) sobre os padrões de crescimento das cidades brasileiras, "o nível de renda é mais elevado em aglomerações urbanas maiores e nas Regiões Sudeste e Sul, mas um indicativo de convergência regional, com maiores taxas de crescimento em áreas pobres, é também verificado".

\section{Gráfico 5 - Crescimento anual da renda nas regiões}

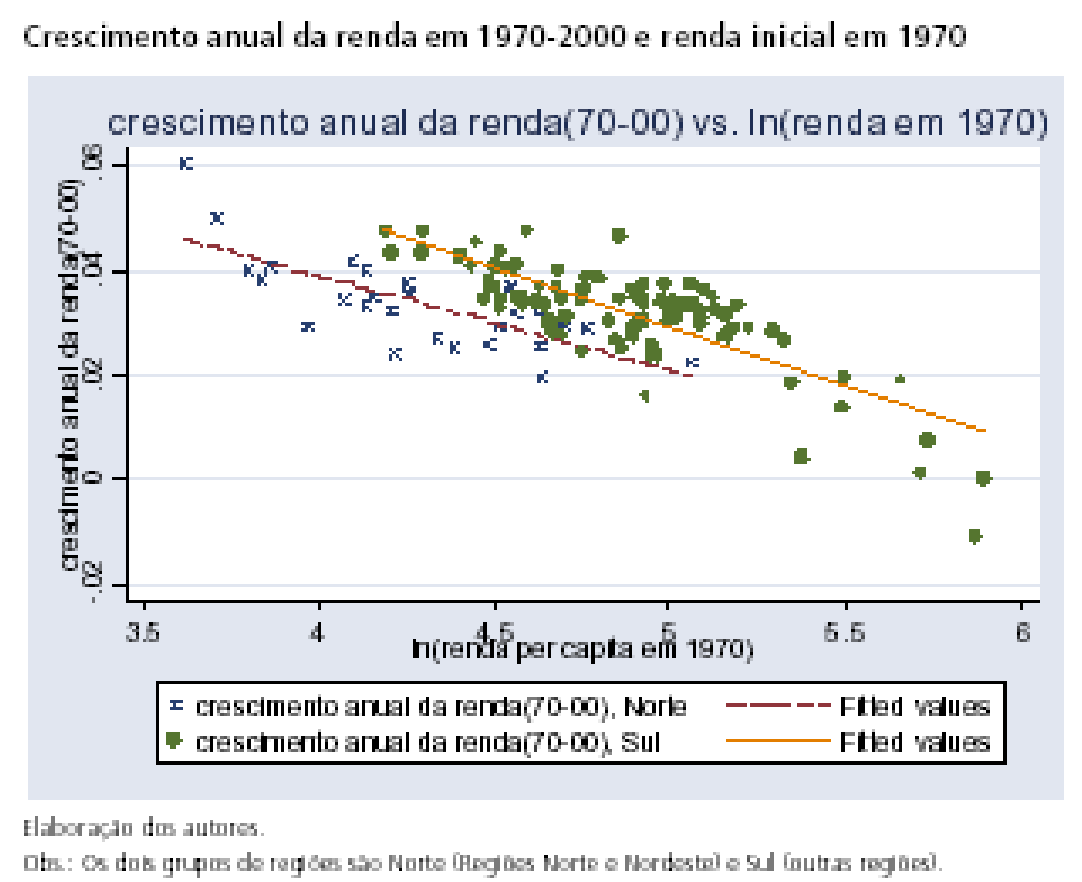

Fonte: DA MATA et al (2005)

Para o Banco Mundial (2000) - uma das agências financiadores do desenvolvimento das economias periféricas - os bens e serviços são mais eficientemente produzidos em áreas mais densamente povoadas que provêem acesso ao conjunto de mão-de-obra qualificada, redes de firmas complementares que atuam como supridoras, e uma massa crítica de clientes (conceito de economia de aglomeração).

Isso parece fazer sentido no caso de cidades como São Paulo e Rio de Janeiro no período da urbanização crescente, que reuniram (ou foram providas) de condições atrativas para o capital. As cidades nordestinas, por exemplo, sofriam, e ainda sofrem, com condições climáticas adversas por certas adversidades, carências de infraestrutura e de redes de transporte. 
Por outro lado, Da Mata (2005) também destaca que as aglomerações urbanas das Regiões Norte e Centro-Oeste estão crescendo mais do que os centros urbanos já estabelecidos do eixo Sudeste-Sul. Para os autores, a dinâmica dessas economias apresenta um processo de diversificação crescente entre grandes cidades e, de maior especialização econômica, em cidades de porte médio. Os grandes centros urbanos como São Paulo, Rio de Janeiro e Belo Horizonte, mostram uma tendência à desconcentração da atividade econômica em direção às periferias.

Quanto a esse ponto, entram discussões de causalidade: se a concentração industrial causou o desenvolvimento regional e crescimento das cidades, ou se as indústrias foram atraídas pelas melhores condições (infra-estrutura, serviços, localização geográfica) das cidades de uma região, ou se isso foi proporcionado ou incrementado pelo Estado.

O pesado investimento estatal em infra-estrutura na década de 1970 , e os incentivos fiscais, baixos salários, e atratividades de recursos naturais de alguns estados começa a provocar mudanças no quadro tradicional de concentração industrial no Sudeste e expandir novas fronteiras econômicas para outras regiões, com as economias de aglomeração, impactando a dinâmica regional, e conseqüentemente, a dinâmica de urbanização nacional. Pode-se perceber esses "focos de dinamismo" em algumas regiões, como Nordeste, em que por iniciativas dos próprios estados, oferecem subsídios fiscais para atrair indústria em conseguir alavancar algum tipo de desenvolvimento, nem que seja local e temporário.

\section{$\mathbf{v}$}

A grande mudança no perfil de ocupação territorial no Brasil dá-se entre as décadas de 1960-1970 como já visto, com a inversão da característica de população nacional, de rural para urbana, especificamente. Em cinqüenta anos (1950 a 2000) a população brasileira teve incremento de mais $200 \%$ no seu número de habitantes, acompanhada de perto pelo crescimento total da população urbana, e inversamente pela rural. A densidade demográfica brasileira, que era de $6,1 \% \mathrm{hab} . / \mathrm{km}^{2}$, passou a 19,92\% hab./km² (GIRARDI ,2008). 


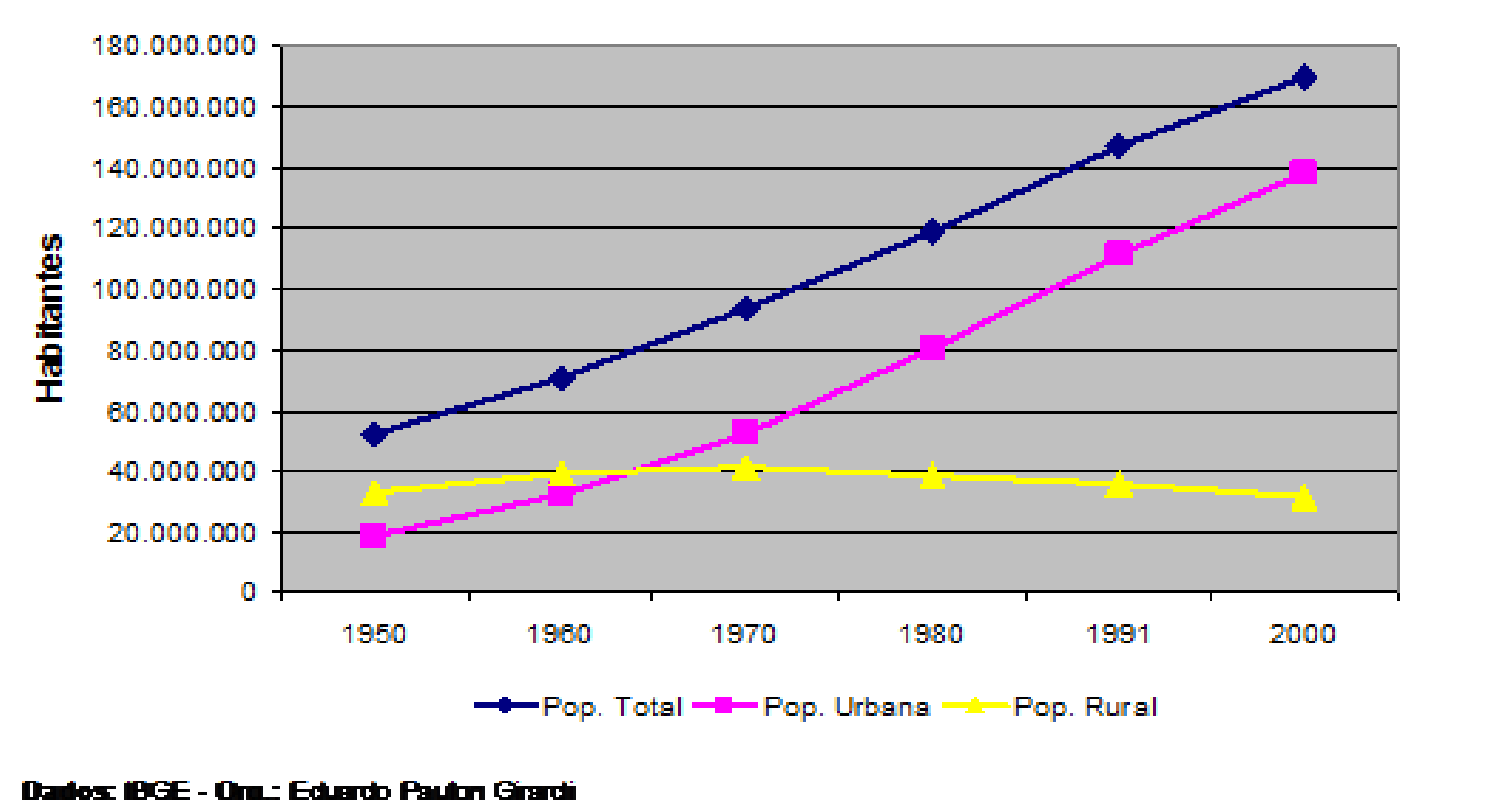

Na segunda metade do século XX o cenário nacional é de uma urbanização acelerada, com taxas crescentes de inversão populacional de rural para urbana, principalmente nas regiões de maior concentração industrial, a saber, a Sudeste. 0 Sudeste foi região que mais recebeu incremento de população devido à industrialização, mas nas últimas décadas a expansão da fronteira agrícola e modernização do campo também provocou um grande afluxo populacional nas regiões Centro-Oeste e Norte, mas com densidades ainda inferiores à média nacional.

"A diferença regional é veemente, visto que em 2000 o Sudeste, região com maior densidade demográfica, possuía 78,2 hab./km2, enquanto a densidade demográfica da região Norte era de 3,3 hab./km2. A evolução da densidade demográfica nas cinco regiões foi positiva e constante no período 1950-2000. Apenas uma pequena diferença pôde ser notada no Sudeste, com um crescimento mais acelerado a partir de 1970, e também no Nordeste, que teve diminuição no ritmo do crescimento da densidade em 1970 e manteve a progressão desde então" (GIRARDI, 2008). 
Gráfico 7 - Evolução da densidade demográfica regional - 1950-2000

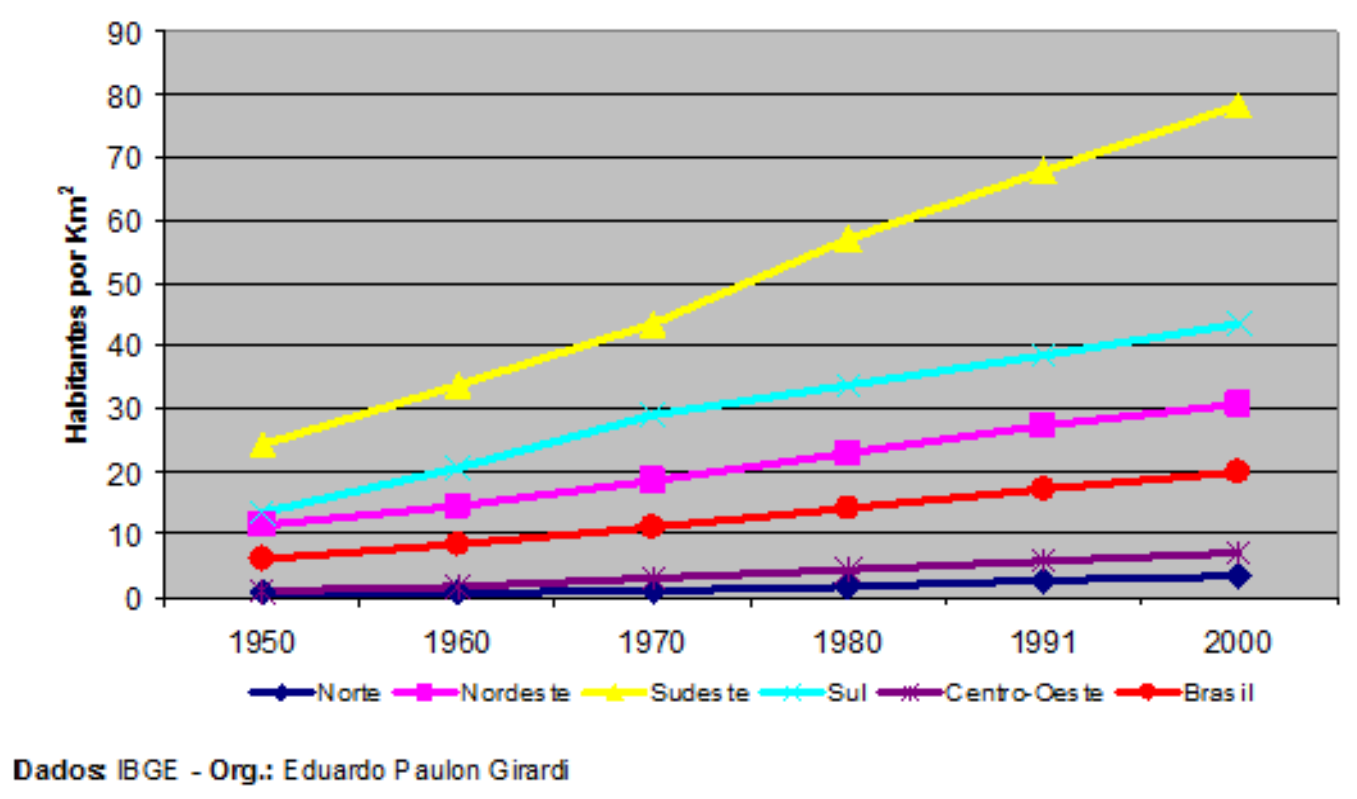

Apesar de esse processo sofrer uma desaceleração a partir de meados da década de setenta pauperização de algumas regiões e o enriquecimento de outras interferiu diretamente nos movimentos de migrações inter e intra-regionais. Outra faceta desse processo é o impacto que essas mudanças trouxeram sobre as políticas urbanas enquanto processos de tomadas de decisões, e que as decisões tomadas enquanto políticas urbano-regionais trouxeram sobre 0 inter e o intra-urbano, especificamente.

Fica claro pela leitura dos mapas (Mapa 3) que a concentração populacional se dá, sobretudo na região Sudeste e nas capitais litorâneas (principalmente capitais de Estado e regiões metropolitanas), assim como os maiores índices de densidade demográfica também refletem essa concentração de população. No entanto, em década mais recente, como pode-se ver no mapa de evolução da população, vê-se que um aumento da ocupação do território amazônico, bem como de áreas do CentroOeste. 
Mapa 3 - Mapas de População Total em 2000, Evolução da População Total de 1991 a 2000 e Densidade demográfica, em 2000

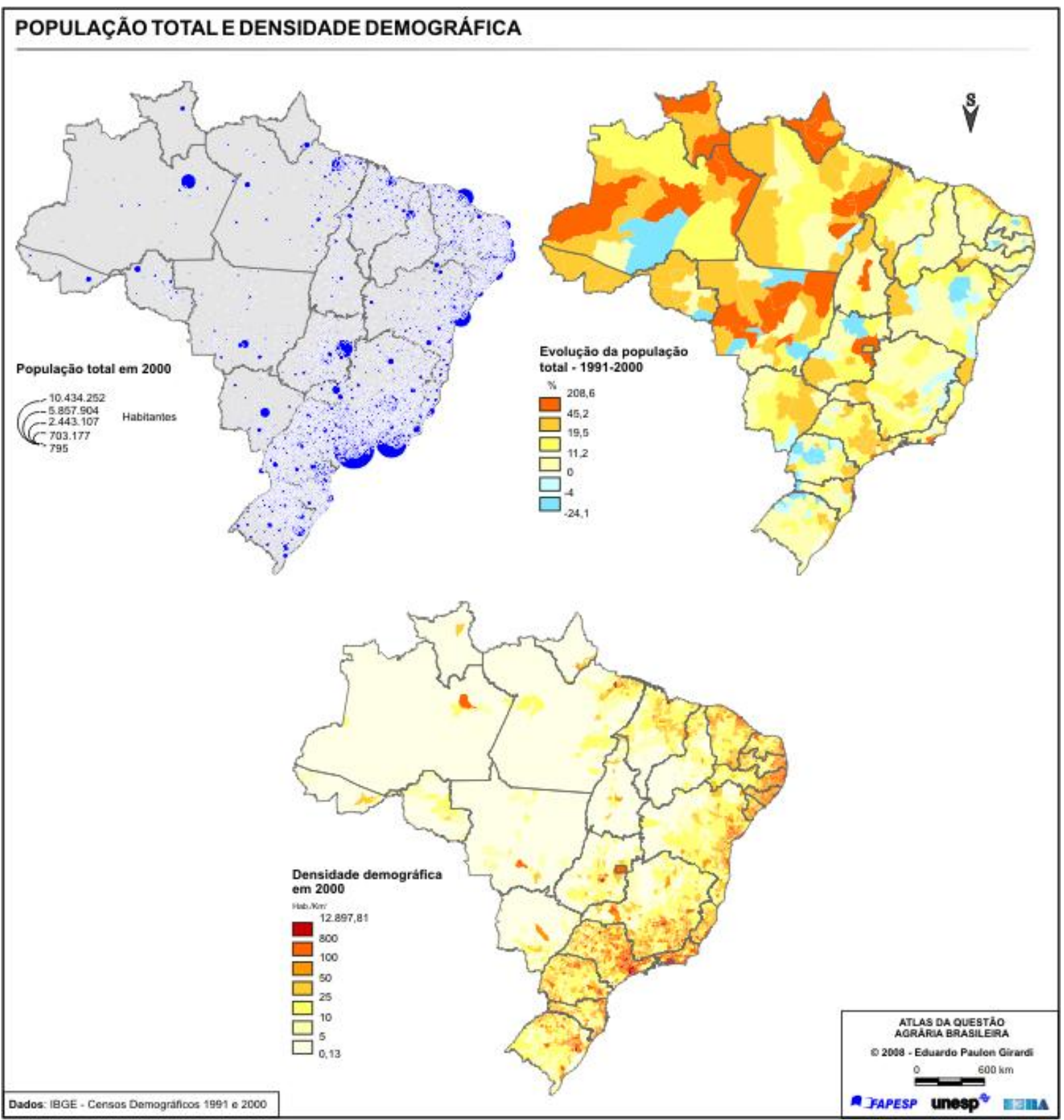

Fonte: Girardi, 2008.

Em virtude dos fluxos migratórios internos (inter e intra-regionais), as taxas de população urbana regionais também sofrem um incremento. $A$ atratividade das novas possibilidades de enriquecimento com a produção da soja, do arroz, do milho - ou seja, do agronegócio - principalmente nos estados do Centro-oeste iniciou um movimento de ocupação, não rural, mas urbana, com a criação de novas cidades, mais ainda de baixos índices de densidade demográfica. Apesar desse destaque, o grande movimento migratório ainda é para o Sudeste, mas com sinais de movimento inverso, uma vez que as deseconomias de aglomeração e atratividade das cidades de média porte confirmou-se como uma tendência nos últimos anos. 
Mas não foram apenas as migrações interregionais que alteraram as taxas de população urbana, mas também as migrações intra-regionais, com transferência de população do interior para as capitais dos Estados. Esse foi também um grande fator de contribuição para a formação das ocupações urbanas irregulares nas periferias urbanas, uma vez que a falta de perspectivas, emprego, o preço da terra "urbanizada", de políticas sociais integradas, levam a uma situação de exclusão generalizada.

Gráfico 8 - Evolução da população urbana regional - 1950-2000

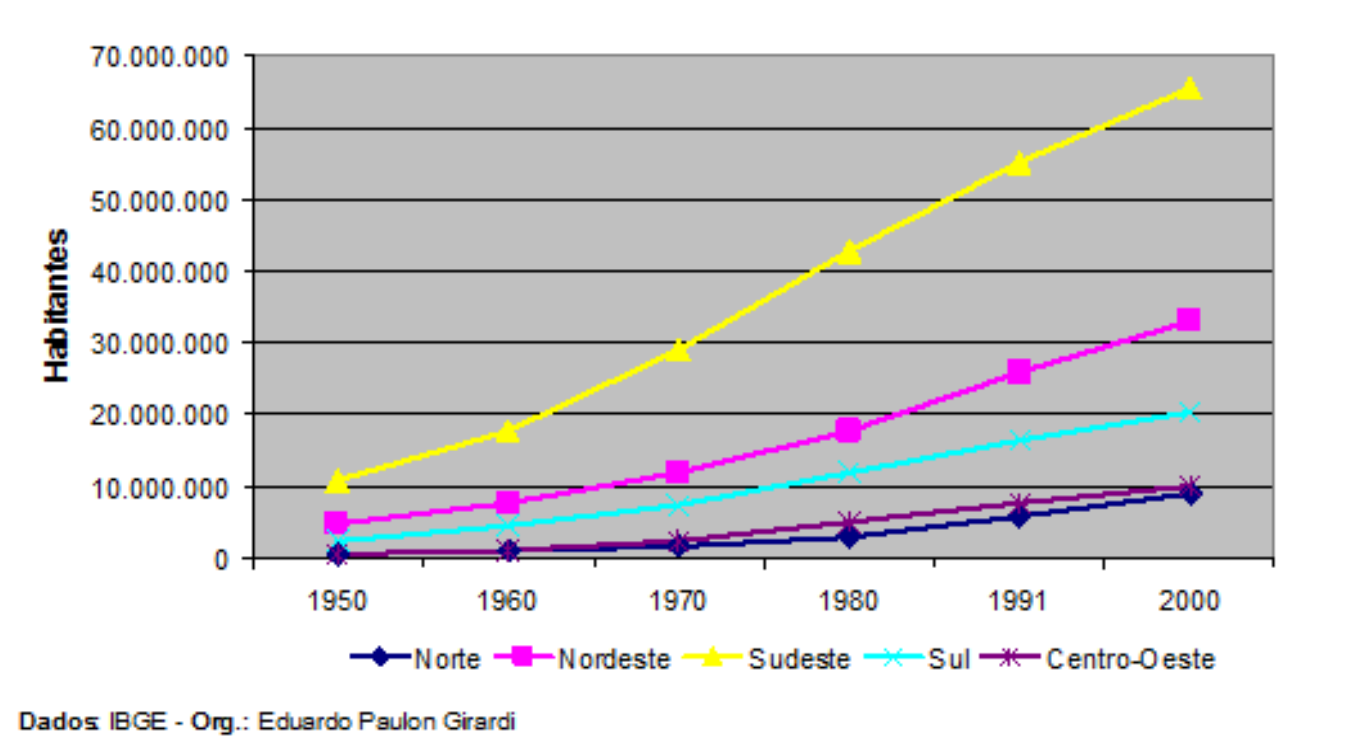

Vê-se no gráfico acima que mais uma vez que a região Sudeste apresenta o maior crescimento de população urbana entre as regiões, por razões diversas já anteriormente expostas. Isso claramente se reflete na mancha de concentração urbana, como se vê no mapa abaixo, com altas taxas de urbanização principalmente em São Paulo, Rio de Janeiro, sul de Minas, Goiás e Mato-Grosso e Mato-Grosso do Sul, enquanto nas áreas mais claras do mapa (Norte, Nordeste e boa parte do Sul) em 2000 ainda encontram-se com as mais baixas taxas de urbanização.

Fatores diversos explicam essas diferenças, mas as questões econômicas estão no cerne do desequilíbrio regional, como ver-se-á no item seguinte. 
Mapa 4 - Mapa de População Urbana em 200, Evolução da População Urbana de 1991 a 2000 e Taxa de Urbanização em 2000.

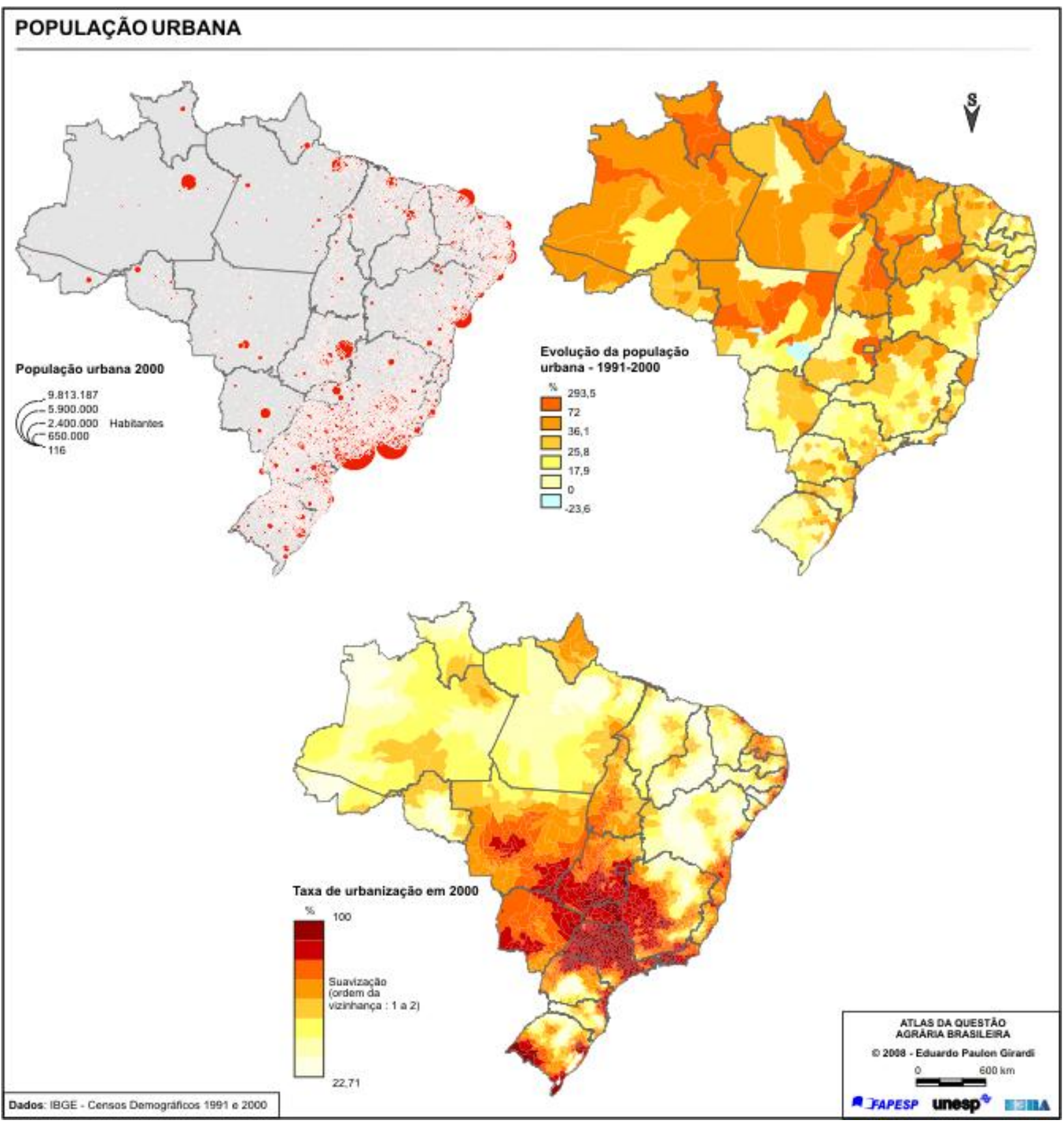

Fonte: Girardi, 2008.

É esse o quadro a ser enfrentado pela nova PNDU, que embora não tendo seu foco as políticas de desenvolvimento regional, como na PNDU de 1975, entende que a assimetria e heterogeneidade das condições de vida regionais, funcionam como elementos de atratividade ou de repulsa de parte da populacional, grande parte, que se localiza à margem dos processos produtivos e de acumulação do capital, formando uma massa de excluídos, não só economicamente, mas territorialmente, 
fundiariamente falando, uma vez que a terra se torna também mercadoria, e a terra urbanizada, um privilégio de poucos incluídos ${ }^{59}$ da cidade legal.

\section{Mapa 5 - Mapa da exclusão/inclusão de São Paulo60}

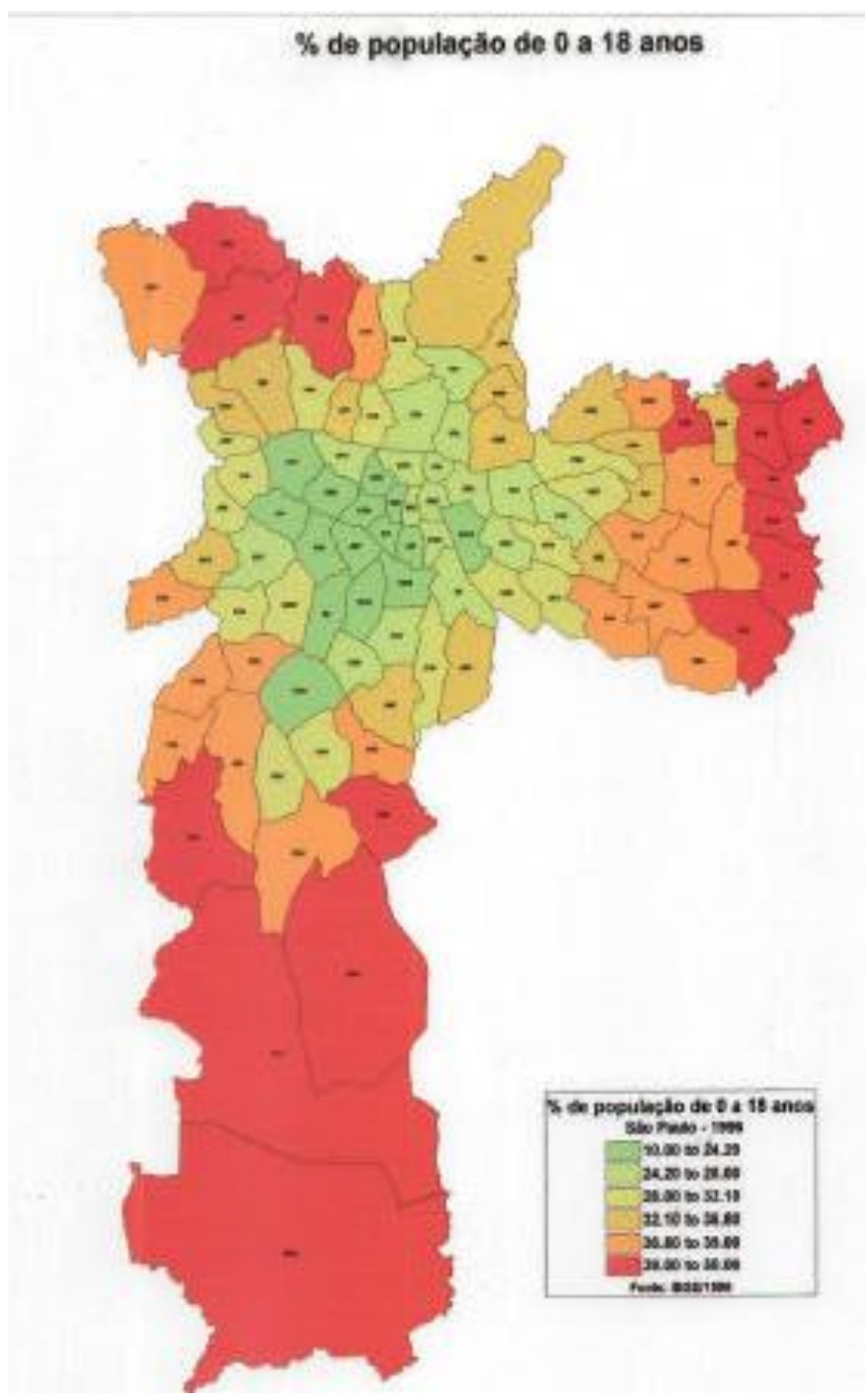

Fonte: NEPSAS Núcleo de Estudos e Pesquisas sobre Seguridade e Assistência Social da PUC/SP, 2 000. Leitura: De verde a vermelho, de excluídos a incluídos, mostrando concentração de incluídos no centro e excluídos nas "franjas" urbanas, longe do centro, ou dos corredores de valorização imobiliária, que possuem a terra mais "urbanizada" e de preço mais alto. De verde a vermelho, de excluídos a incluídos, mostrando concentração de incluídos no centro e excluídos nas "franjas" urbanas, longe do centro, ou dos corredores de valorização imobiliária, que possuem a terra mais "urbanizada" e de preço mais alto.

\footnotetext{
59 "A partir do que a ONU/PNUD discute como indicadores de desenvolvimento humano - IDH, entendeuse que a inclusão social implica em: autonomia, desenvolvimento humano, qualidade de vida, equidade. Nestas quatro utopias foi construído o Mapa da Exclusão/inclusão Social de São Paulo em 1996. A maturação desta análise exigiu que neste novo século três novas utopias the sejam agregadas: democracia; cidadania; felicidade". Mapa da Exclusão/Inclusão Social - uma metodologia. Analisar a exclusão é antes de mais nada desenhar a utopia da inclusão. NEPSAS Núcleo de Estudos e Pesquisas sobre Seguridade e Assistência Social da PUC/SP, 2000. Disponível em < http://www.dpi.inpe.br/geopro/exclusao/oficinas/metodologia mapa.pdf> Acesso em: 09.06.2010.

${ }^{60}$ De verde a vermelho, de excluídos a incluídos, mostrando concentração de incluídos no centro e excluídos nas "franjas" urbanas, longe do centro, ou dos corredores de valorização imobiliária, que possuem a terra mais "urbanizada" e de preço mais alto. Fonte (Ibidem).
} 


\subsubsection{A PNDU de 1975: foco nas regiões e metrópoles}

A PNDU era definida como "o elemento da política nacional de desenvolvimento que diz respeito ao processo de urbanização em suas dimensões inter e intra-urbana" (SERRA, 1991, p. 83). A abrangência assim, tinha a pretensão de cobrir todo o território nacional, o que demandava também impactos sociais, e obviamente tornava incompatíveis essas diretrizes com as limitadas competências do ministério responsável no momento. A PNDU de 1975 propunha uma abrangência espacial intra e interurbana, mas principalmente interurbana, no nível regional.

A idéia de que "a ocupação populacional do território se realiza em função, principalmente, do atendimento de necessidades econômicas e sociais", era o discurso da PNDU de 1975 (MINISTÉRIO DO INTERIOR, 1975, p. 14). Pelos relatos de Sousa (2004, p. 114), duas concepções de espaço dominavam o pensamento urbano brasileiro na década de setenta: uma globalista - "que procurava lidar com o espaço brasileiro como uma totalidade manifesta no território - e a setorialista, "com uma visão segmentada do urbano, entendida como a somatória da habitação, do transporte, do saneamento básico, da gestão administrativa, das finanças". Esta visão acabou por predominar na elaboração da PNDU, apesar da tentativa dos planejadores de vincular a política urbana à política global de desenvolvimento do país, para em certo sentido romper com a visão puramente setorialista.

É a partir dessa tentativa que a política é concebida dentro de um modelo territorial que congrega diretrizes de atuação para cada área diferenciada pela sua função dentro do sistema econômico e a associação a um conjunto de ações setoriais, técnicas, administrativas e institucionais que compuseram a PNDU. O desenvolvimento urbano no Brasil era, então, assumido como sendo função " (i) dos fatores de investimento na infra-estrutura econômica (ii) do sistema urbano existente (iii) da política setorial de investimento no meio urbano (iv) e da política fiscal e financeira do setor público ". Pode-se dizer que a cidade era entendida como um elemento, um ponto, dentro do sistema "funcional-econômico" urbano / regional / metropolitano nacional.

O discurso era da necessidade de fomento à industrialização das regiões mais desenvolvidas, as denominadas pólos ou centros (sudeste principalmente), e prover condições para as regiões com problemas de ocupação e desenvolvimento de suas 
funções produtivas, as periféricas, de potencial econômico e de mão-de-obra pouco aproveitados, com construção de estradas e provimento energético para instalação das indústrias e "condições" para o assentamento da mão-de-obra que certamente acompanharia o fluxo dos investimentos. O planejamento para cada região deveria ser pensado dentro da elaboração do seu Plano Diretor de Desenvolvimento Urbano.

Na PNDU de 1975 o discurso oficial demonstrava uma preocupação em se fomentar o desenvolvimento econômico das cidades-pólo e principalmente regiões e áreas metropolitanas "pouco industrializadas" - ou seu papel no circuito industrial pouco desenvolvido- ou ainda sem a sua economia de escala.

O texto capitular da primeira PNDU afirma que "embora com esses problemas, é a partir das metrópoles e dos grandes centros urbanos que se processa a difusão da modernização e do desenvolvimento, e é na eficácia do desempenho das funções metropolitanas que se apóia, em grande parte, o desempenho da economia e a difusão dos impulsos de modernização. Em vista disso, cumpre fixar objetivos específicos para o desenvolvimento dos sistemas urbanos que venham a ser considerados na própria elaboração das políticas e das diretrizes do desenvolvimento nacional" (MINISTÉRIO DO INTERIOR, 1975, P. 73).

Procurando visualizar a rede urbana brasileira congregando esses elementos funcionais com critérios de "população, importância sócio-econômica, área de influência e número de centros urbanos atraídos", o IBGE propôs a seguinte classificação espacial do sistema urbano nacional, que era levando em consideração pela PNDU (MINISTÉRIO DO INTERIOR, 1975, p. 16).

\footnotetext{
- $\quad$ Grande metrópole nacional - São Paulo;

- Metrópole Nacional - Rio de Janeiro;

- Centro Metropolitanos regionais - Recife, Belo Horizonte, Salvador e Porto Alegre;

- $\quad$ Centros macrorregionais - Curitiba, Fortaleza, Belém e Goiânia.
}

A preocupação com as regiões metropolitanas, instituídas em 1973, era patente nessa classificação. Segundo Souza (2004), na PNDU a abordagem era nitidamente metropolitana, sendo a dinâmica intra-urbana uma segunda dimensão da política urbana metropolitana. O fenômeno da conurbação, ou seja, cidades vizinhas que pela proximidade com grandes centros acabavam por serem polarizadas pelas 
atividades dessas cidades-pólos não só poderia alimentar as economias de aglomeração, como também aglomeração de problemas.

Às regiões metropolitanas também eram direcionados planos específicos, mas estimulava-se que seus problemas fossem tratados de acordo com a idéia de serviços comuns, procurando-se estabelecer uma ação integrada entre os três níveis de governo. Mas já se apontava a "dificuldade em operacionalizar uma política urbana que integrasse o sistema de cidades com as políticas setoriais", alinhando interesses dos diversos agentes sociais do poder público, privado e da sociedade.

A questão territorial, entendida aqui como o objetivo principal de integração nacional, era tratada de acordo com a geopolítica preconizada pela escola superior de guerra, sob a égide filosófica do geógrafo e estrategista Gen. Golbery do Couto e Silva. Segundo Souza, "a integração nacional tinha como base de operação o desenvolvimento regional, procurando por meio dele criar um mercado interno capaz de promover o desenvolvimento auto-sustentável e a progressiva descentralização econômica - mais uma vez em discurso - por meio dos pólos de desenvolvimento, principalmente no Nordeste e no Centro-Oeste e Amazônia" (SOUZA, 2004, p. 122),

As regiões metropolitanas eram 9, e 8 as cidades com mais de 500.000 habitantes, que polarizavam as demais cidades do País. Em 1970 o número de municípios brasileiro eram 3.985 (congregando várias cidades, vilas e pequenas aglomerações urbanas). Pela ONU (Organização das Nações Unidas), a população urbana refere-se somente aglomerados com no mínimo de 20.000 habitantes, no Brasil, então, dentro dessa classificação, tinha no período 351 núcleos nessa faixa de população, 303 cidades e 48 vilas. Para os efeitos de mapeamento desse quadro urbano nacional no momento, as cidades brasileiras foram divididas categorias segundo o tamanho de população em:

- Centros metropolitanos: acima de 500.000 habitantes

- Centros urbanos: na faixa de 50.000 a 500.000 habitantes

- Centros urbano/locais: população entre 20.000 e 50.000 habitantes

A Tabela 2, o Gráfico 8 e o Mapa 6 dão as dimensões e distribuição dos níveis de urbanização das cidades brasileiras na década de 70 . 
Tabela 2 - Total de cidades por região, classificadas em número de habitantes (PNDU de 1975)

\begin{tabular}{|l|c|c|c|c|c|c|c|}
\hline HAB/REGIOEES & $\mathbf{2 0 . 0 0 0}$ & $\mathbf{5 0 . 0 0 0}$ & $\mathbf{1 0 0 . 0 0}$ & $\mathbf{5 0 0 . 0 0 0}$ & \multicolumn{2}{c|}{ TOTAL } \\
\cline { 2 - 7 } & $<\mathbf{5 0 . 0 0 0}$ & $<\mathbf{1 0 0 0 0 0}$ & $<\mathbf{5 0 0 . 0 0 0}$ & $<\mathbf{1 . 0 0 0 . 0 0 0}$ & $\mathbf{1 . 0 0 0 . 0 0 0}$ & \\
\hline Norte & 3 & 2 & 1 & 1 & 0 & $\mathbf{7}$ \\
\hline Nordeste & 42 & 11 & 10 & 1 & 2 & $\mathbf{6 6}$ \\
\hline Sudeste & 103 & 25 & 30 & 0 & 3 & $\mathbf{1 6 1}$ \\
\hline Sul & 33 & 15 & 8 & 1 & 0 & $\mathbf{5 7}$ \\
\hline Centro-oeste & 7 & 2 & 3 & 0 & 0 & $\mathbf{1 2}$ \\
\hline BRASIL & $\mathbf{1 8 8}$ & $\mathbf{5 5}$ & $\mathbf{5 2}$ & $\mathbf{3}$ & $\mathbf{5}$ & $\mathbf{3 0 3}$ \\
\hline
\end{tabular}

Fonte: Ministério do Interior, 1975.

Gráfico 9 - Distribuição nacional de cidades, por, classificadas por total de habitantes (PNDU de 1975)

TOTAL DE CIDADES POR CLASSIFICAÇÃO

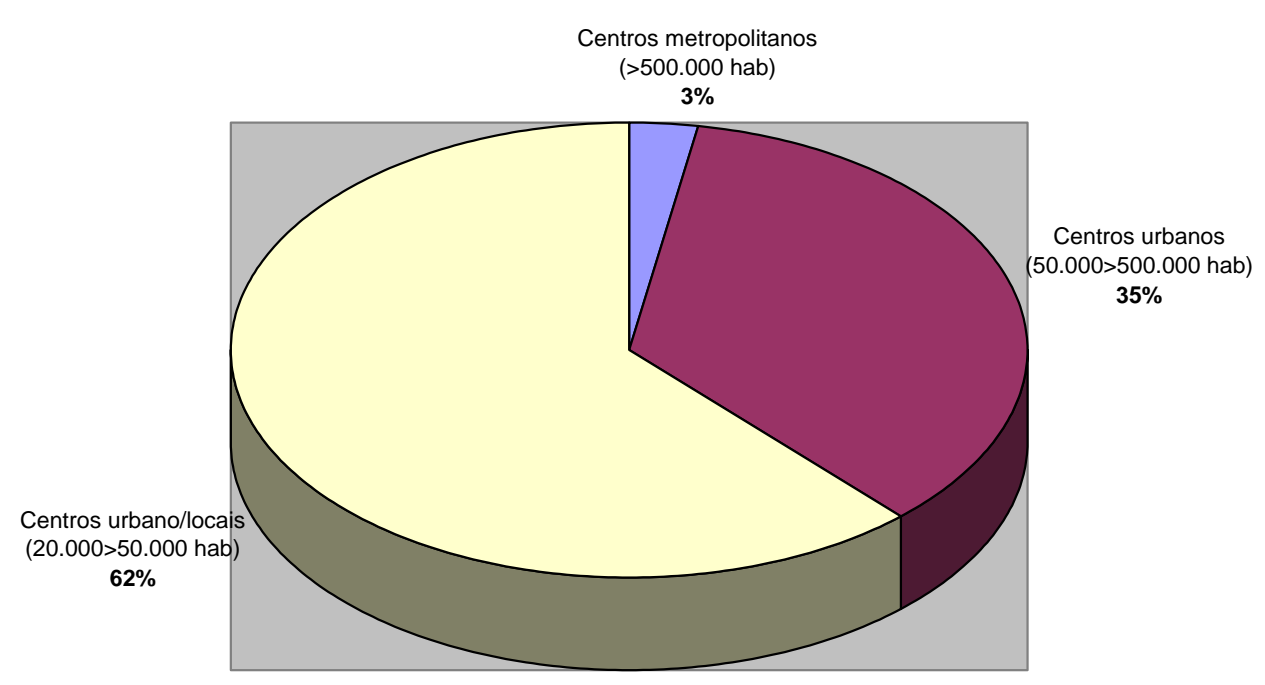


DISTRIBUIÇÃO REGIONAL DAS CIDADES BRASILEIRAS, SEGUNDO OS NÚMEROS DE HABITANTES, EM 1970 (IBGE)

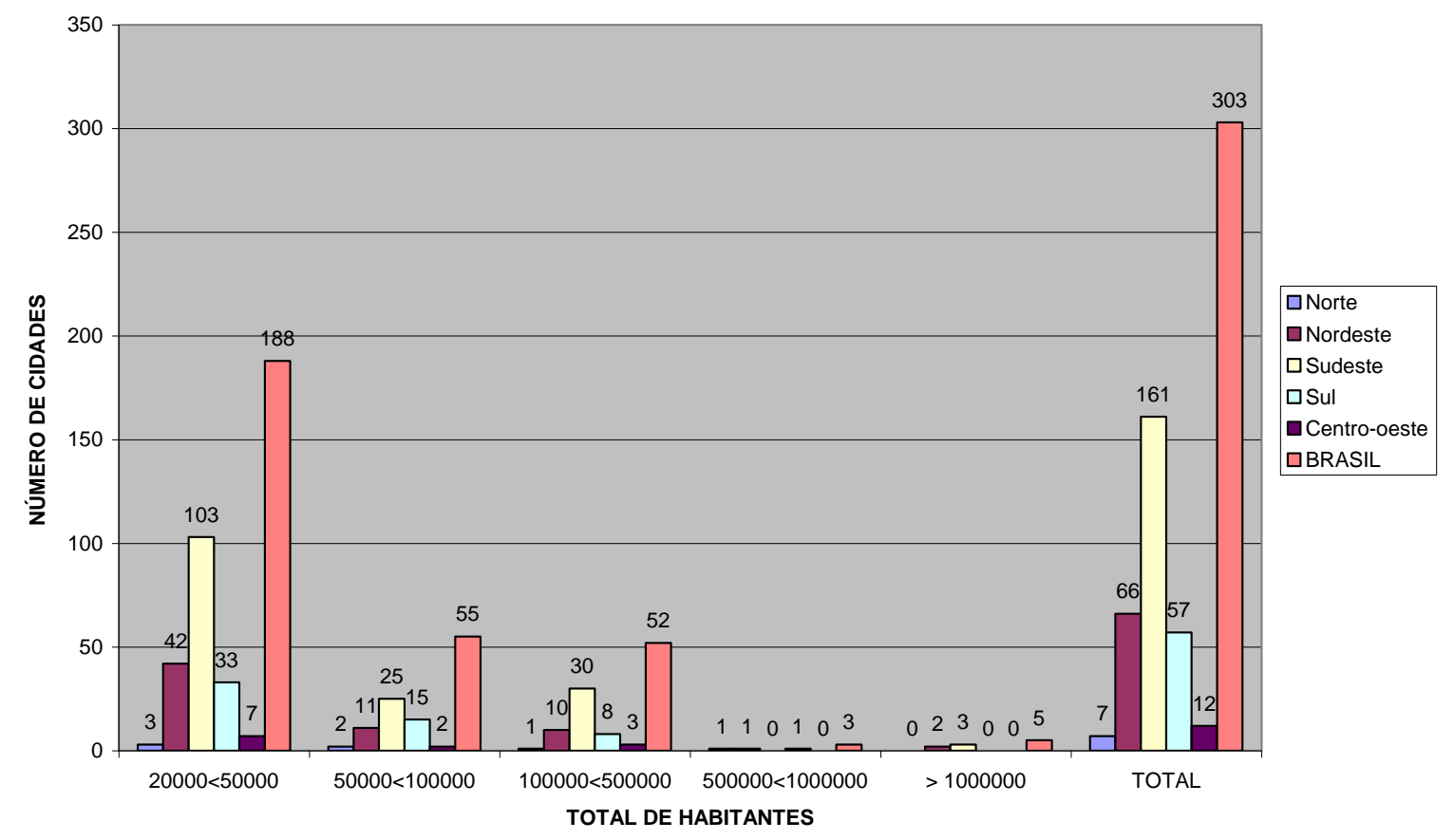

Fonte: Gráfico elaborado pela autora a partir dos dados do IBGE.

Mapa 6- Distribuição das cidades brasileiras com mais de 50000 habitantes, por classe de tamanho - 1970

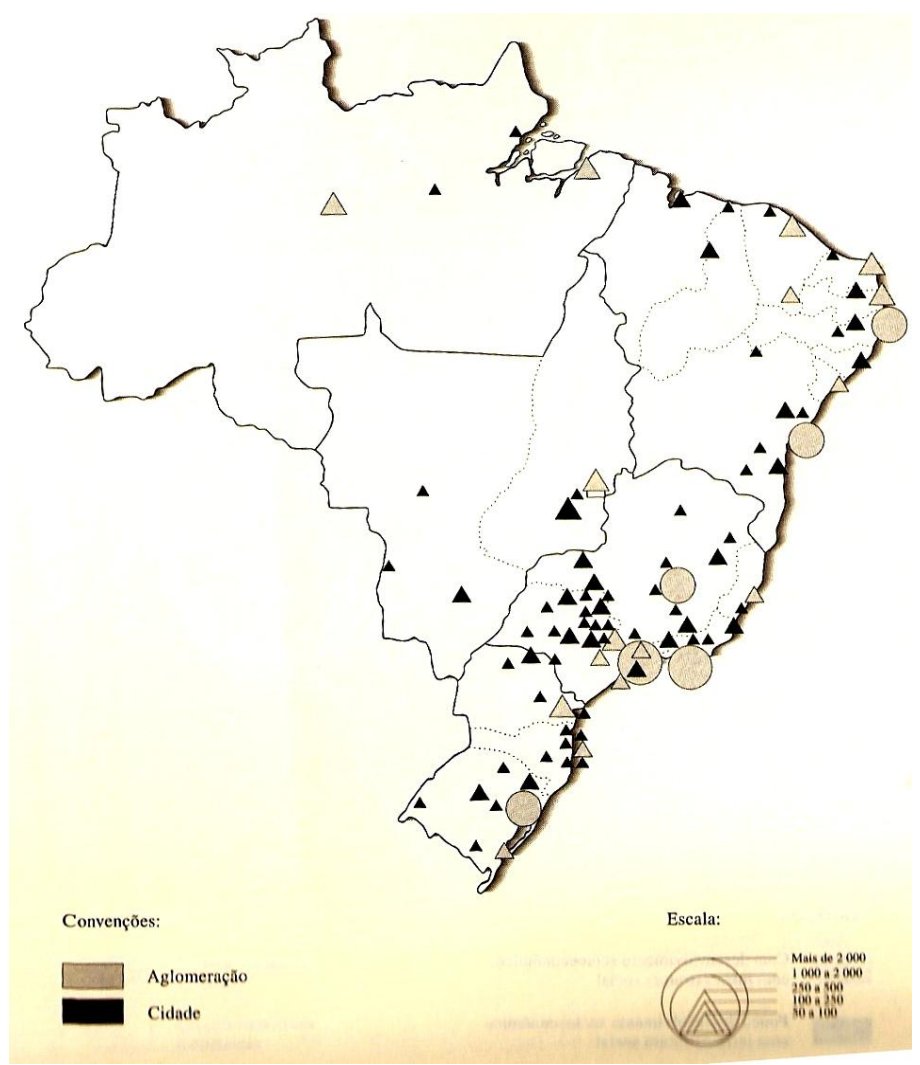

Fonte: Souza (2004). 
O tratamento do planejamento urbano ocorreu dentro de uma combinação entre o planejamento territorial e os planos diretores, o primeiro dando conta da espacialização das políticas governamentais, as regionalizações, o planejamento regional e as políticas de descentralização, enquanto os planos diretores davam conta da gestão das cidades, dentro do que se entendia por uma "análise integrada para o enfrentamento da crise urbana". Os principais setores de atuação eram a habitação e equipamentos urbanos, o planejamento territorial, o saneamento, o transporte e o meioambiente, que deveriam seguir diretrizes nacionais, regionais, metropolitanas e urbanolocais (municipais).

A ação centralizadora do Estado se justificava como forma de prover a estrutura necessária desses planos, traduzida na assertiva de que "ainda que o planejamento do espaço intra-urbano seja prerrogativa dos governos municipais, os grandes investimentos exigidos pela urbanização acelerada e as prioridades setoriais em áreas como transportes, energia, comunicações, habitação e saneamento induzem o Governo Federal a uma co-participação decisiva" (MINISTÉRIO DO INTERIOR, 1975, p. 77). Pode-se dizer que essa era tônica da "cooperação intergovernamental" preconizada no texto da PNDU.

Pode-se dizer que a PNDU de 1975 procurou - frise-se mais uma vez que em discurso - em cada uma dessas escalas " promover o fortalecimento e a melhor estruturação do sistema urbano nacional e dos subsistemas regionais, com vistas à redução dos desequilíbrios existentes; maior eficácia no desempenho das funções urbanas, e elevação dos padrões de urbanização e de qualidade da vida urbana (MINISTÉRIO DO INTERIOR, 1975). No entanto, já viu-se que na prática, as ações fomentaram o desequilíbrio regional e concentração do sistema e os planejamento intra-urbano, apesar de "bons exercícios técnicos e diagnósticos", não foram capazes de mudar os rumos da problemática urbana em ascensão.

\subsubsection{A PNDU de 2004: o foco no município}

\section{I}

A supressão da escala nacional, ou regional, ao longo das últimas décadas tem bases principalmente econômicas e financeiras. Uma dessas causas está em mudanças significativas na ordem mundial, como a globalização, e na escala nacional, 
a descentralização política, que acarretaram profundas transformações na concepção do espaço regional e da dinâmica territorial, demandando para o desenvolvimento dos Estados a reorganização das suas relações internas e externas.

Em função das novas articulações planetárias advindas com a era da informação, a globalização introduziu uma nova ordem econômica pós-industrial, percebendo-se uma "pulverização" das barreiras geográficas como marcos delimitadores de uma demanda de reordenação espacial em escala mundial. Para Vainer (2007) "hoje, a desconstituição parece atualizar-se numa espécie de conformada aceitação da fragmentação territorial que consagra a acomodação subordinada às formas contemporâneas da globalização".

Seguindo essa lógica, novas relações nas ordens econômicas e políticas advindas com a globalização e reforçadas pelo neoliberalismo determinaram novas escalas espaciais da ação política, como a global, nacional e local/regional, assinalando a superação do debate nacional $\mathrm{x}$ internacional, pelo debate local $\mathrm{x}$ global (VAINER, 2001). Vainer aponta que os globalistas defendem a esfera global como campo e arena para a ação política e decretam a falência do Estado nacional; os nacionalistas defendem a construção de um projeto nacional de Estado e a resistência à dissolução das soberanias nacionais; e os localistas defendem o local como centro de ação do global nos mais diversos aspectos de economia, política, sociedade etc.

$\mathrm{Na}$ PNDU de 1975, uma prioridade foi desenvolvimento de políticas de ocupação do território, para ocupação das áreas inóspitas ou crescimento econômico das áreas menos desenvolvidas do território nacional. No plano da política territorial, isso implicava em promover políticas de ocupação do centro-oeste e Amazônia e políticas de desenvolvimento para o norte/nordeste, tendo em vista que o eixo sudeste nesse momento já era o principal lócus da atividade econômica nacional, notadamente pelo avanço industrial e pelas políticas econômicas empreendidas para essa região. Externamente, implicava em manter o Brasil em posição privilegiada em relação às estratégias geopolíticas norte-americanas, para conter "o avanço das investidas socialistas soviéticas sobre o mundo".

Esse quadro é alterado após a redemocratização do país, a dissolução do bloco Soviético e, no plano econômico, a globalização via mercado, ao lado da fragilização dos estados nacionais. 
Os Estados Nacionais foram e continuam sendo desafiados por forças poderosas que não são apenas externas, umas vez que estão presentes e articulam-se internamente. Embora condenados a desempenhar papel secundário na etapa que se abre, o Estado Nacional constitui arena e instrumento indispensável de qualquer projeto que pretenda preservar a soberania política, a cultura própria e a possibilidade de construir uma nação que escolha seus próprios caminhos (MINISTÉRIO DAS CIDADES, 2004a, p. 29).

Tânia Bacelar (2008) critica a máxima neoliberal "pensar globalmente e agir localmente". Para a economista, autora de várias pesquisas sobre o desenvolvimento regional, "os agentes globais não querem saber de escala nacional, regulações, querem ter total liberdade nos territórios alheios. A mais contestada é a escala nacional. Afinal, aí é que a luta social conseguiu impor regulações ao capitalismo. A legislação trabalhista é nacional, assim como o salário mínimo, a moeda e o Estado. Para o capital, o território é apenas palco de operações, para mim os territórios são construções sociais. O Brasil muda e redefine sua inserção na era da globalização"

Vê-se que o debate sobre as escalas tem por trás mais que questões territoriais, mas interesses econômicos os mais diversos que acabam por se manifestar, positiva e negativamente, sobre o espaço urbano. As cidades tornam-se palco de disputas pelos mais diferentes agentes, tornando-se, portanto, o princípio e o fim do planejamento urbano.

O controle do uso e ocupação do solo urbano precisa se materializar em ações exeqüíveis de ordenamento do espaço. Para que isso ocorra de forma homogênea na heterogeneidade não pode prescindir da política urbana, formulada e executada pelo poder público, congregando aspectos físicos, de planificação, mas também políticos e sociais na definição das diretrizes para o desenvolvimento urbano.

Enquanto na década de setenta a questão regional e a metropolitana ocupavam o centro das atenções e das estratégias de planejamento nacionais, pode-se dizer que nas últimas décadas, principalmente a partir da década de 1990, com a globalização e liberalização da economia, as cidades passaram a ser a grande questão dos debates e dos embates políticos sobre o desenvolvimento urbano. Vários fatores contribuíram para esse cenário: o agravamento da crise urbana; a falência do planejamento urbano 
tradicional; a supressão da escala nacional e a valorização da escala local; para citar alguns.

A cidade torna-se então o reflexo exato do tipo de produção social do espaço urbano que estava por trás desse novo projeto "neoliberal": desigual, desequilibrada, injusta e não democrática, pelo menos na prática. O desenvolvimento urbano mais justo, equilibrado, com garantia de acesso à terra urbanizada e moradia digna à populações excluídas são as reivindicações dos movimentos de luta urbana, contrários ao ideário neoliberal, e de certa forma assumido em discurso nos governos de esquerda, primeiramente locais (prefeituras e depois Estados), e depois pelo Federal, mas em todas as escalas, certamente um discurso de difícil implementação pelos diversos interesses em jogo e conflitos existentes.

A cidade é agora disputada pelos mais diversos interesses, não só locais, mas também globais. $O$ foco nas cidades e na escala local como locus de investimento do capital financeiro, e não mais só industrial, é cenário para atratividades externas que reforçam o modelo competitivo de cidades e a inexistência de um projeto nacional de desenvolvimento urbano - ou limitado ao discurso oficial - em favor das relações transnacionais do local com o global.

A ausência de uma política nacional de desenvolvimento não só era patente no começo desse processo, principalmente na década de 1990, como se tornou uma (não) política de governo. O Estado nacional submeteu-se à cartilha neoliberal e globalizante, que praticamente anulou a escala nacional como instância de se pensar o urbano, elegendo a escala local e a "terceirização" dos serviços públicos como instância e política de governo para o provimento das demandas urbanas básicas ${ }^{61}$.

A supervalorização da escala local - a cidade ou município - como instância principal das políticas e planejamento de Estado fica constitucionalmente reforçado com a determinação dos municípios como entes da federação a partir de 1988 e do estabelecimento dos planos diretores municipais como instrumentos básicos da política urbana, desde então prenunciada. O Estatuto da cidade, a lei federal que regulamentou a política urbana nacional em 2001, como visto, estabelecendo as diretrizes para o

\footnotetext{
${ }^{61}$ Não coincidentemente explodem experiências de gestão local a partir da década de 90, engrossando um movimento dúbio de inovação na gestão, mas também de atendimento às exigências dos grandes bancos mundiais para liberar recursos para o governo nacional.
} 
desenvolvimento e as competências dos entes federados, tangencia a questão regional e metropolitana - cujo planejamento estaria a cargo do Estados - mas é de fato a escala local que prevalece como foco principal das políticas urbanas atuais.

\section{II}

Na PNDU de 2004, diferentemente do contexto de 1975, verifica-se claramente uma preocupação maior voltada ao aspecto intra-urbano do planejamento. Do legado de desequilíbrios regionais e o acirramento da crise urbana, as preocupações do governo federal se voltaram precipuamente para essa escala municipal, confirmado em 1988, pela Constituição conhecida como "municipalista", quando é dada a sua autonomia como ente federado.

"Além dos temas estruturantes da política urbana ou, mais apropriadamente, da política intra-urbana, a PNDU trata da inserção das cidades na dinâmica regional e no território nacional "(MINISTÉRIO DAS CIDADES, 2004a, p. 8)

O histórico de lutas no processo de redemocratização das políticas urbanas é também primordialmente urbano, da "Reforma Urbana", e devido à configuração atual do espaço urbano, a questão metropolitana também tem estado presente nos debates, uma vez que é na metrópole e nas suas periferias, as cidades "ilegais", que se exacerbam os conflitos urbanos e a sua pior face da desigualdade e exclusão.

Diante disso e dos imensos aglomerados urbanos que se formam nos arredores das metrópoles, como também fora delas, nos morros, em áreas distantes dos centros, em regiões inóspitas, do ponto de vista intra-urbano, a própria definição do que são esses aglomerados, ou seja, do conceito de cidade, é ainda um pouco controversa. Há cidades de 17 milhões de habitantes, como São Paulo, e há cidades com 20 mil habitantes. Há cidades com grandes extensões territoriais, há cidades lineares, com carências de todos os tipos, infra-estruturais, de serviços públicos, de equipamentos urbanos.

Como estabelecer políticas federais voltadas a minimizar os problemas urbanos se as escalas, e a complexidade dos problemas, em termos proporcionais, guardam diferenças gritantes? Justamente por ter o foco nas cidades, essa é uma preocupação que perpassa o texto da PNDU de 2004: "A definição sobre o conceito de 
cidade ou o conceito de urbano envolve aspectos demográficos, antropológicos, culturais, filosóficos, geográficos, sociais, econômicos, entre outros. É, sem dúvida, um debate muito importante, cuja clareza deverá orientar a elaboração de um novo marco legal que substitua o decreto lei 311 de 1938. (...)" (MINISTÉRIO DAS CIDADES, 2004a).

Mapa 7 - Distribuição de população urbana em situação 1, 2 e 3 - 2000

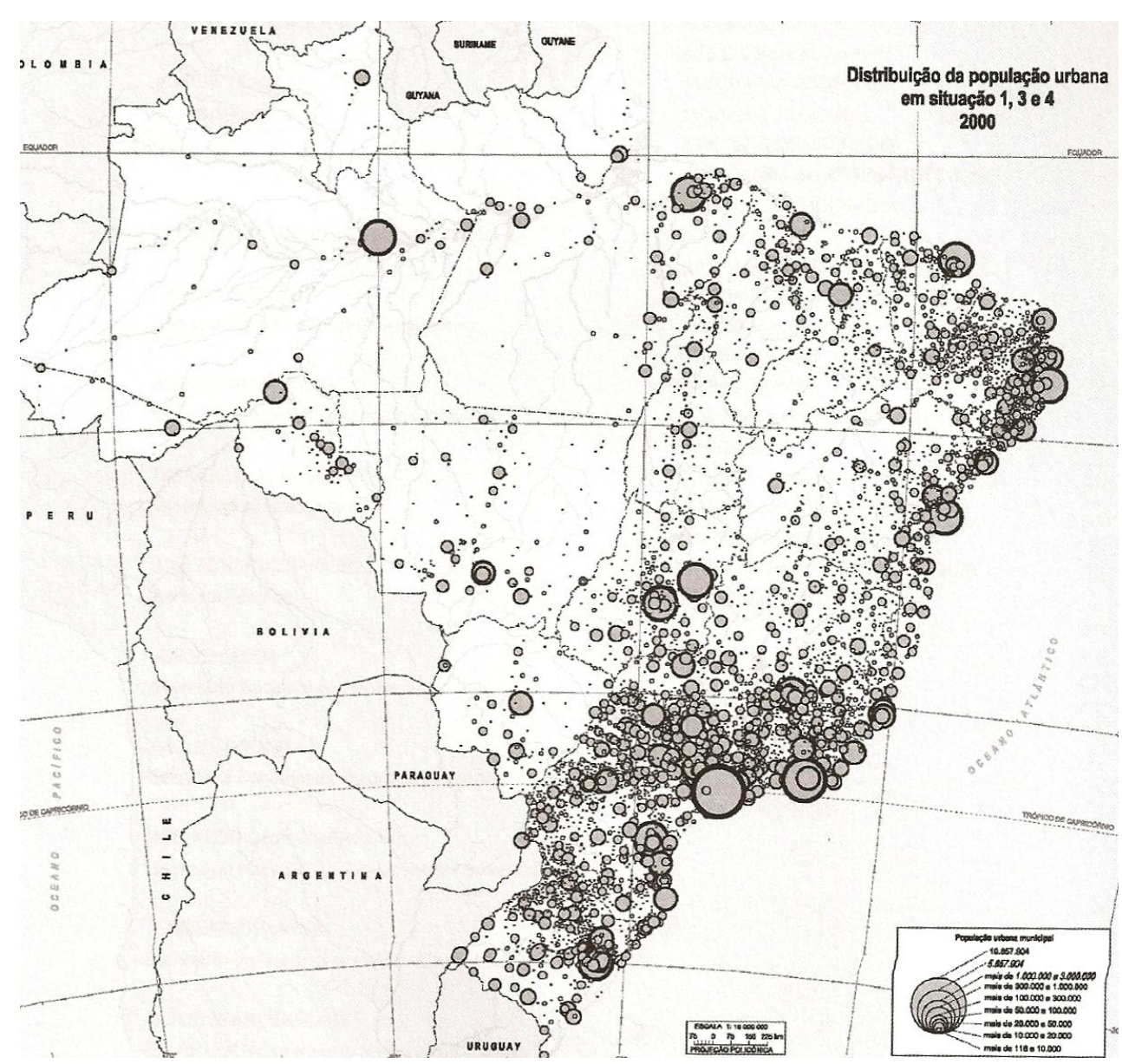

Fonte: Caderno MCidades No 1, 2004a (Mapa do IBGE).

Segundo o IBGE a população urbana é formada pelos habitantes das seguintes localizações de área:

1. "Áreas urbanizadas de cidades ou vilas: "são aquelas legalmente definidas como urbanas, caracterizadas por construções, arruamentos e intensa ocupação humana; as áreas afetadas por transformações decorrentes do desenvolvimento urbano, e aquelas reservadas à expansão urbana.” (IBGE, 2000. v.7, não pag.). 2. Áreas não-urbanizadas de cidades ou vilas: "são aquelas legalmente definidas como urbanas, caracterizadas por ocupação predominantemente de caráter rural." (IBGE, 2000. v.7, não pag.). 3. Áreas urbanas isoladas: "áreas definidas por lei municipal, e separadas da sede municipal ou distrital por área rural ou por um outro limite legal." (IBGE, 2000. v.7 não pag.)." (GIRARDI, 2008) 
A PNDU de 2004 levou em consideração esses conceitos. Pelo Mapa 7 pode-se ver que a concentração de população urbana continua litorânea, mas com mudanças significativas a partir da transferências da Capital, da continuidade da expansão da fronteira agrícola no centro-oeste e das cidades planejadas como Goiânia, Tocantins, e tantas outras não planejadas, filhas da soja, do interior do Mato-grosso e Mato-grosso do Sul, e outros núcleos que vão se formando ao redor da metrópoles, muitas delas cidades dormitórios e cidades-satélites, que ampliam o escopo da categorização.

Segundo dados do Censo 2000, 79,9\% da população brasileira reside em "área urbanizada de vila ou cidade", de acordo com a definição citada acima. Pelo Censo de 1991, 74,6\% da população residia neste tipo de setor: "considerando apenas 3 dos 8 itens ("área urbanizada de vila ou cidade" - situação 1; "área urbanizada isolada" situação 3; e "rural-extensão urbana" - situação 4), nos quais a ocupação urbana é melhor caracterizada já atingiríamos o mesmo patamar de $81 \%$ dos números divulgados pelo IBGE para 2000 e de $76 \%$ para 1991.

\begin{abstract}
"Mesmo considerando que é sempre possível mais de uma interpretação para as definições utilizadas - o que são exatamente áreas "afetadas por transformações decorrentes do desenvolvimento urbano" e áreas "reservadas à expansão urbana?" - as considerações acima nos levam a apontar que, segundo critérios próprios do IBGE e não apenas a definição legal dos municípios, os novos números da população urbana seria da mesma ordem de grandeza que os números mais amplamente divulgados. Essa constatação nos permite confirmar que o país é maciçamente urbano e é suficientemente adequada para continuarmos, por enquanto, a utilizar os números que se referem à população urbana brasileira para dar prosseguimento à elaboração da Política Nacional de Desenvolvimento Urbano." (MINISTÉRIO DAS CIDADES, 2004a, p. 84)
\end{abstract}

As políticas de apoio do governo federal ao planejamento intra-urbano se concentram em temas como: planos diretores municipais (participativos e que incorporem os instrumentos do Estatuto das cidades); regularização fundiária (para minimizar o problema da cidade ilegal, irregular e informal); prevenção de riscos em assentamentos precários (devido ao grande número de escorregamentos em encostas); reabilitação de centros urbanos (repovoamento e reutilização das áreas ociosas dos centros abandonados). Além disso, tenta promover ações interministeriais no trato da gestão e ações cooperativas entre os governos, a fim de promover o fortalecimento da federação, além das questões metropolitanas. 
Como visto, o foco da atenção espacial não se limita às políticas e ações físicoterritoriais nas cidades, mas também aos aspectos de gestão municipal, uma vez que o município tornou-se, o principal executor da política e do planejamento urbano, papel esse reforçado pelo Estatuto da Cidade.Com isso os municípios tiveram a sua autonomia legalmente garantida, porém, na prática a gestão dos problemas urbanos requer muito mais de recursos, instrumentos e respaldos institucionais que vão além das competências municipais.

O governo federal, por meio do Ministério das Cidades, comprometeu-se com a criação de políticas de apoio aos municípios e Estados quanto ao seu papel no planejamento urbano e gestão territorial (MINISTÉRIO DAS CIDADES, 2004b) ${ }^{62}$. "O papel do governo federal na viabilização de sua implementação é fundamental, não apenas porque este concentra parcela significativa dos meios de financiamento à implementação dessa política, mas também em função da conhecida fragilidade técnico-institucional de boa-parte dos municípios para levar a cabo essa importante tarefa" (MINISTÉRIO DAS CIDADES, 2004b).

\section{III}

Apesar de ter uma base fortemente municipalista, é fato que a PNDU de 2004 não ignora em seu conteúdo a importância central das metrópoles no desenvolvimento econômico e urbano do País.

Terreno de contrastes, onde a alta concentração da riqueza produz uma alta concentração de pobreza, a metrópole congrega em sua espacialidade algumas das piores distorções de ocupação do solo urbano. E não se pode esquecer, que a metrópole, apesar de remeter à referência sempre regional, tem sua centralidade polarizada pelo município-sede, pólo, centro, seja como for a denominação, é o centro da exacerbação dos conflitos e interesses dos diversos atores que disputam seus espaços e vantagens de aglomerações.

Por isso a atenção da nova PNDU se volta também para a construção de uma política nacional para as metrópoles, direcionando uma série de medidas, tanto de

\footnotetext{
62 Esse discurso, de "apoio" do governo federal aos demais níveis de governo, porque não têm recursos nem aparato institucional para "dar conta da tarefa", mesmo que na melhor das intenções e sendo de fato algo necessário, não pode deixar de ser registrado como bem próximo do discurso utilizado na primeira PNDU para justificar a ação centralizadora e autoritária do governo federal.
} 
investimentos em infra-estrutura para as metrópoles, como relativas à gestão metropolitana, como de incentivo ao planejamento físico-territorial dessas regiões, prevendo instrumentos de regulação dos usos do solo, zoneamento industrial, habitação e infra-estrutura, em consonância com os Planos Diretores locais.

Essa perspectiva de "gestão integrada" metropolitana, integrando espacialidades múltiplas e problemáticas de dimensões também múltiplas e diferenciadas,, tem sido o grande "gargalo" da questão metropolitana nas últimas décadas, sem que tenha recebido devida atenção dos poderes públicos envolvidos, ou seja, a cooperação das três esferas de governo para superação desse vazio institucional.

Cabe ressaltar de qualquer forma que, a partir da criação do Ministério das Cidades, em 2003, se a Política de Desenvolvimento Urbano cabe a ele, a questão territorial em escala mais ampla foi atribuída ao Ministério da Integração Nacional e à Secretaria de Assuntos Estratégicos, vinculada à Presidência da República.

\subsubsection{Considerações: planejamento territorial, o desequilíbrio regional e "vazio" metropolitano}

\section{I}

Segundo Vainer (2007), "a história recente do planejamento territorial no Brasil poderia ser narrada como uma trajetória continuada, embora não linear, de desconstituição política, evidenciada no desaparecimento progressivo da questão regional da agenda nacional, e operacional, com a desmontagem dos aparatos institucionais que, na segunda metade do século passado, foram implantados pelo governo federal para conceber e implementar políticas, planos e projetos cujo objetivo explicitamente enunciado era o ordenamento territorial e a redução das desigualdades regionais, mas esvaziados de função e sentido, tornaram-se em nichos de articulação de interesses paroquiais e de reprodução de elites quase sempre decadentes".

O período a que se refere Vainer é o que vai da década de 50 ao final da década de 70 , de promoção do desenvolvimento de grandes planos estruturantes do espaço nacional, de preocupação com o ordenamento territorial e redução dos desequilíbrios regionais. Nesse período foram criadas as regiões metropolitanas, como mais uma escala de organização territorial, devido à aglomeração de cidades em torno 
de uma cidade-pólo, que atraíam grandes contingentes populacionais em torno de suas atividades econômicas.

A questão das escalas estava bem presente. Como dito, estavam em voga: a questão regional, com os programas de desenvolvimento regional e superintendências regionais financiadores de tal desenvolvimento; a questão metropolitana, com a criação das novas metrópoles, carentes, no entanto, de instâncias de planejamento e gestão adequadas a essa escala; a rede urbana nacional, sem uma política nacional que integrasse e equilibrasse o desenvolvimento urbano pelo país; e a cidade em si, como centro do planejamento local integrado, mas onde se manifestavam de forma exacerbada os principais problemas decorrentes da urbanização em marcha.

Apesar das várias escalas, a dicotomia "urbano-regional" é que predomina em termos de planejamento urbano, falando-se em uma "moldura urbano-regional para o desenvolvimento nacional" (CINTRA, 1978: 181). Para o período, Cintra defende que "estariam em jogo decisões em duas amplas frentes, uma delas voltada para a rede urbana nacional, vista como um todo, a ser alvo de políticas de ocupação territorial, e a outra voltada para as próprias cidades como lugares onde as atividades setoriais, principalmente levando-se em conta a sua proximidade física, se tornam interdependentes". O foco de atenção voltado para as cidades em si, ou seja, o planejamento intra-urbano sobressaindo-se ao planejamento nacional ou regional tornou-se uma realidade que se confirmou ao longo dos anos, seguindo a tendência de transformação das cidades em centros da produção e reprodução por excelência das demandas do capital, em suas diversas fases.

A força executiva das políticas urbanas estava concentrada nas localidades, nos municípios. Havia por parte da União, uma "notável ausência de decisões importantes e de políticas unificadas quanto aos problemas urbanos. Em outras palavras, tendo crescido as cidades e tendo-se formado áreas metropolitanas, o corte urbano não foi incorporado à formulação de políticas públicas federais como um critério dotado do mesmo grau de convicção característicos dos planejamentos global e setorial (ou funcional) para a concepção, organização e administração de programas e, para a alocação de recursos" (CINTRA, 1978, p.180)

Segundo diagnóstico na nova PNDU, "até os anos 90, a diretrizes de desenvolvimento urbano regional privilegiaram, inicialmente, a concentração de 
investimentos e de esforços de planejamento nas nove regiões metropolitanas instituídas na década de 70, para as quais foram criadas agências técnicas de planejamento." (p. 36)

Visto como se deu historicamente a atuação em termos de política e planejamento urbano e territorial, observa-se que dada a intervenção enviesada do Estado, procurando garantir as condições para produção e reprodução do capital nas cidades, o planejamento urbano no Brasil produziu um tipo de organização espacial que, em lugar de mediar relações de classe e garantir o equilíbrio da relação entre o público e privado, fomentou as condições de apropriação privada do espaço, em detrimento do público, e agravou o distanciamento e o antagonismo entre as classes.

É interessante aqui pontuar a opinião de Bacelar (2008), citando Lídia Goldenstein (1994), sobre duas observações muito importantes para compreender o papel desempenhado pelo Estado brasileiro na montagem de processos concentradores e geradores de desigualdades. Uma diz respeito ao papel do Estado como provedor, não dos interesses sociais, mas dos interesses industriais e desenvolvimentistas, e outra, decorrente desta, de fomentador das desigualdades sociais e regionais.

Sobre a primeira característica, Bacelar diz, inicialmente, que "aqui atuou um Estado desenvolvimentista, que foi o grande patrocinador da expansão da atividade econômica nos anos recentes". Como apresentado anteriormente, esse foi o período dos grandes investimentos estatais em infra-estrutura (estradas, comunicação, energia) e preparação das cidades para receber o desenvolvimento industrial.

Bacelar destaca que nesse mesmo período, o Estado de bem-estar social se desenvolvia em outras áreas do mundo, mas o Brasil nunca teve um Estado essencialmente provedor de educação, saúde, saneamento básico etc., mas sim que construía estradas, montava sistemas de comunicação, estatizava empresas para modernizá-las e ofertar insumos básicos muitas vezes a preços mais baratos que os custos de produção e assim por diante.

Para ela, o "Estado brasileiro foi o grande condutor do que os marxistas chamariam 'desenvolvimento das forças produtivas'. Foi esta a tarefa principal que o Estado atribuiu a si próprio, especialmente na passagem do Brasil agrário-industrial, no 
século XX". Essa orientação estratégica, aliás, aparece nos lemas dos diversos governos:'Fazer cinqüenta anos em cinco', de Juscelino Kubitschek, ou 'construir o Brasil grande potência', do período militar. Foram estes os grandes slogans que orientaram a presença do Estado na vida social do país. Por isso mesmo, tem-se um Estado muito ausente no campo social.

Todos os meios, toda a energia, estavam concentrados na tarefa de construir a oitava economia industrial do mundo ou o Brasil grande potência." E pelo que foi visto nos textos anteriores, um Estado ausente não só no campo social, mas urbano também, pela clara inversão de prioridades e interesses mediante as investidas do interesse privado. Não pode-se dizer que se construiu a oitava economia do mundo, mas que se deixou de construir cidades mais organizadas e justas, bem como um desenvolvimento territorial mais equilibrado.

Com isso, a economista acredita que o Estado desenvolvimentista brasileiro tem outra característica: é um Estado desenvolvimentista conservador. E justifica por que: "Este é um país que consegue aumentar significativamente a produção agrícola, colocar cerca de $80 \%$ da população nas cidades em menos de meio século e ser um grande produtor de alimentos, sem fazer reforma agrária. Tal façanha foi possível porque a base agropecuária transbordou para o Centro-Oeste.

Nessa região, foi preciso construir cidades, levar estradas, montar sistemas inteiros de comunicação e de armazenagem - tudo isso a custo elevado - para não mexer com a estrutura de propriedade nas áreas de ocupação já consolidadas. Eis aí uma marca do Estado brasileiro como agente histórico da produção de desigualdades, tanto sociais quanto regionais. Em escassos momentos, o Estado desenvolvimentista brasileiro conduziu políticas regionais ativas e contribuiu para amenizar a trajetória da produção e reprodução das desigualdades entre as regiões ou assistiu suas empresas produtivas investirem na desconcentração da base industrial no amplo território do país."

Cintra (1978, p. 177) afirma que quando se colocam interesses nacionais em jogo, da sociedade como um todo, "eles são interpretados e defendidos pelo prisma particular das coalizões de elite, históricas e concretas, cujos interesses, em tais circunstâncias particulares, podem sobrepor-se aos interesses da nação e ser vistos como coincidentes com estes". 
A opinião de Bacelar (op. cit) confirma o quadro da desigualdade regional crescente a partir das décadas de sessenta e setenta, e apesar do discurso da geopolítica na época objetivar o equilíbrio e redução das desigualdades regionais, o planejamento estatal desenvolvido desde então não tem sido capaz de se transformar em políticas e projetos eficazes para o desenvolvimento regional e urbano. Assim, pode-se considerar que as políticas e planejamento do Estado, desde o período militar, com as estratégias geopolíticas , e mais recentemente, com as novas "regras do jogo" após a constituição de 1988 foram marcada pelos interesses de uma pequena burocracia ou externos, bem como gerador de grandes desigualdades, intra-urbanas e inter-regionais.

Para Tolosa (1997),

"convém não esquecer que a tendência da economia brasileira é no sentido da integração cada vez maior do sistema de cidades, e, por essa razão, a maioria dos problemas metropolitanos acaba dependendo de medidas implementadas fora do perímetro da grande metrópole. Isso significa dizer que, nos sistemas com alto grau de interdependência interna, os efeitos das medidas de política econômica implementadas no vértice superior da hierarquia urbana são rapidamente transmitidos para a base da pirâmide de tamanhos urbanos. Desse raciocínio, conclui-se que a solução dos graves desequilíbrios metropolitanos normalmente transcende o poder de decisão das autoridades locais e requer um enfoque nacional para a problemática urbana." (TOLOSA, 1997, p. 16)

\section{III}

As metrópoles dentro da federação representam uma instância criada pela "força" da necessidade em função da grande concentração populacional e aglomerado de cidades, mas principalmente criadas como parte do plano estratégico de modernização conservadora imposto no período militar, no qual as metrópoles cumpririam função de plataformas de acumulação recebendo os investimentos federais a partir de sua cidade-pólo e cidades médias.

No entanto, a política urbana estratégica de gestão de espaços urbanos "privilegiados" (do ponto de vista de investimentos, mas caóticos de várias outras maneiras) como as metrópoles não evoluiu no mesmo do período de sua criação na década de setenta. Esclareça-se que o ritmo de aparelhamento e apoio para 
institucionalizar a metrópole como instância governativa dos problemas comuns de dada região, como era a proposta da década de setenta quando foram criadas, não evoluiu de forma compatível com a ampliação do número de RMs criadas e com o conseqüente volume de problemas acumulados.

Diferentemente do que aconteceu na década de setenta, quando o governo federal criou as nove primeiras regiões metropolitanas, e as aparelhou com órgãos de gestão e planejamento (por que tinha interesse direto no desenvolvimento dessas regiões), após a nova constituição de 1988 os Estados passaram a ter esse "poder" de criar RMs, que passaram a ser criadas discricionariamente como para dar um "status" de destaque a determinado movimento de aglomeração de cidades com um potencial econômico (seja industrial, serviço, turístico etc), com o fim de atrair políticas de investimento para a região.

As RMs que contam com uma agência metropolitana "viva e ativa" são poucas, predominando uma "governança multilateral" que conta com as intervenções dos governos federal, Estadual e dos próprios municípios membros, com organizações não governamentais, com atores da sociedade, conselhos, agências multilateriais, bancos internacionais, enfim, uma gama de atores fazem parte do "imbróglio" que se tornou a gestão metropolitana e as determinações e execuções de políticas urbanas para a região.

Além desse vários atores que participam ou podem requerer participação no seu processo de gestão, as RMs dependem de recursos do governo federal, são regidas pelos estados que, como dito, detêm o poder de criá-las e determinarem as ações executivas nessa instância territorial. Mas o fato de não terem um identidade governativa definida, ou seja, nem estado, nem município, mas uma alglomerado de municípios, uma macrorregião, dificultam a criação de uma identidade metropolitana local, ou seja, de entrar nas agendas públicas e sociais para criação de políticas específica ou conjuntas.

É o que se vê na prática, com raras exceções, de total despreocupação ou falta de empenho em se trabalhar questões conjuntas dentro das RMs. Em relato sobre a participação municipal, um técnico de uma prefeitura de município de médio porte integrante de uma importante RM do interior de São Paulo, afirma que foi criada uma Câmara Temática de Planejamento da RM para se ter encontros mensais sobre temas 
de interesse comum dos municípios, mas segundo o técnico, a participação tem sido baixíssima, comparecendo em torno de $20 \%$ dos municípios membros e, que devido à ausência de participantes, os encontros estão praticamente extintos, e crê que seja difícil que se desenvolvam trabalhos ou projetos conjuntos, pela falta de interesse patente dos participantes.

Segundo Souza (2003) as RMs e as agências criadas para sua gestão padeceram dos conflitos de competência entre esferas de governo e entre unidades da mesma esfera, ou seja, conflitos e tensões nas relações inter e intra-governamentais. No entanto, a autora entende que "conflitos de competência, de jurisdição, de poder e por recursos financeiros são da natureza mesma do sistema federativo e das relações intergovernamentais, ainda que em situações de alta centralização, como a registrada no regime militar".

As RMs perderam espaço com a democratização, argumenta a autora, que justifica essa situação pela teria do path dependency, sendo a política autoritária e centralizadora que concebeu as metrópoles a causa desse "trauma" que bloqueou os desenvolvimento institucional das metrópoles, e afetou a trajetórias das escolhas políticas posteriores, especificamente na constituinte de 1988, em que o objeto principal do planejamento urbano e controle de uso do solo se concentrou na escala territorial da cidade, ou seja, toda força e responsabilidade aos municípios.

É argumento também da autora que as teorias federalistas tradicionais não comportam a análise "espaços territoriais que possuem garantias constitucionais próprias", ou seja, os municípios, que devido à autonomia recebida na Constituição de 1988, quando formam um terceiro centro de poder territorial, e acabam descolados das jurisdições estaduais e, por assim dizer, assumindo vida própria.

A autora defende que no caso da RMs, a consideração dessa dimensão territorial do federalismo se torna particularmente importante, porquanto é nessa dimensão que se concretizam as relações intergovernamentais, de tensão e conflito, bem como "a dinâmica da economia política, dos partidos políticos e da cultura política devem se agregar a outras manifestações territoriais do federalismo, tais como a distribuição de poder dentro do Legislativo e entre níveis de governo, o papel do Judiciário, a alocação de recursos fiscais e de responsabilidades e as garantias constitucionais dos entes que compõem a Federação" (Souza, 2003, p.143). 
As RMs constituem, então, mais uma instância governativa dentro das já tensas e conflitantes relações intergovernamentais, que com a entrada de novos atores e parceiros nos processos de decisão, negociação e implementação de políticas publicas, posiciona as regiões metropolitanas dentro de um "governo de múltiplo nível", que conta ainda com os condicionantes do regime político e institucional que não "evoluíram" a partir do contexto de criação das RMs, mas incorporam novos elementos fiscais, tributários, territoriais, de poder etc, requerendo uma reengenharia políticoinstitucional (ainda por ser "descoberta"), que possa dar conta dessa complexa instância de gestão regional dentro do federalismo que é a metrópole.

\subsection{A QUESTÃO FEDERATIVA}

\subsubsection{Contextos e debates: federalismo e descentralização}

I

O federalismo brasileiro nasceu juntamente com a proclamação da república, com clara inspiração no federalismo norte-americano. No entanto, a história da formação da nação brasileira difere em muito das colônias inglesas, sendo marcada pela dominação externa da metrópole colonial portuguesa e internamente pelas elites oligárquicas regionais.

Oliveira (1995) destaca um aspecto essencial que esteve presente na formação da federação americana e esteve claramente ausente na formação da federação brasileira: um movimento que nasce da consciência de cidadania ${ }^{63}$. Segundo ele, esse foi, e continua sendo, o grande diferencial que dá sentido à federação de um país, que no Brasil, parece persistir mais um sentimento "antifederalista", que um sentimento nacional federalista. Para ilustrar, a massa da população brasileira mal sabe do que se trata uma federação.

Segundo Abrucio (2005), isso se explica porque o Estado brasileiro nasce de cima para baixo, ou seja, a União antes dos estados, diante da necessidade do governo central (Imperial) impor limitações e regras ao poder latente das oligarquias subnacionais. Essa disputa entre governo central e os demais governos foi

\footnotetext{
${ }^{63}$ WESTPHAL afirma que o que é crucial para a compreensão do federalismo americano é que desde 1787 o sistema federal norte-americano tem sido moldado por uma sociedade dinâmica e alterado pelos pensamentos de milhões de homens e mulheres (WESTPHAL, J., 1995).
} 
característico da formação federal brasileira, e afeta diretamente o pacto federativo, dando lugar a uma altercação por controle de recursos, em lugar da interdependência e cooperação entre as unidades.

Amaral Filho (2000) defende a tese de que não há uma fragilidade da federação brasileira, mas sim uma configuração "imperfeita" baseada na inobservância ou descumprimento dos princípios básicos inerentes ao federalismo, como a coordenação (controle pela União) e a cooperação entre os entes federados. Há quem conteste essa tese, uma vez que essa "imperfeição" é a característica própria do federalismo nacional, que pior que essa característica seria a assimetria entre as suas unidades. A trajetória histórica do federalismo no Brasil apresenta avanços e retrocessos de centralização e descentralização do Estado, expressando momentos de controle ou abertura política na relação entre governos nacionais e subnacionais. Esse autor caracteriza como "pendular" o movimento do federalismo brasileiro, observando o conteúdo das cartas constitucionais e o tipo de governo impresso a partir delas.

A constituição de 1934, por exemplo, apresenta um misto de Estado forte com discurso de descentralização (atendendo ao desejo das oligarquias regionais). Porém, as tensões sociais da época diante da "ameaça comunista" instaurou o Estado Novo em 1937 com uma nova Constituição que garantia mais poderes ao Estado fortemente centralizado e politicamente repressor, sob a justificativa da integração e desenvolvimento nacionais. Após a segunda guerra mundial, a pressão da elite industrial por mais liberdade na economia, aliada aos efeitos "democratizantes" do pósguerra no Brasil, levaram à queda da ditadura varguista, e à promulgação de uma nova Constituição em 1946, de cunho mais liberal, democrata e descentralizador (BRASIL, 2010).

O contexto seguinte foi de disputas partidárias de esquerda e direita, entre interesses de trabalhadores e elites industriais, dentro de planos nacionalistas e desenvolvimentistas comandados e patrocinados pelo governo. Forças centralizadoras e descentralizadoras disputavam o poder, até que o golpe militar de 1964, que instaurou a ditadura centralizadora e repressora da liberdade de expressão e da democracia. A Constituição de 1967 corroborou essa centralização pelo governo federal, mas incorporou novos elementos ao pacto federativo: dividiu as responsabilidades dos entes federados; criou os fundos de participação dos 
municípios; e criou mecanismos de correção das desigualdades regionais na forma de incentivos fiscais.

\section{II}

Nas décadas mais recentes, a descentralização e a democratização foram características marcantes do contexto político nacional. A descentralização foi um tema central da agenda da democratização nos anos 1980, como reação à concentração de decisões, recursos financeiros e capacidade de gestão no plano federal, durante os vinte anos de autoritarismo político e burocrático. Essa foi a tônica que deu lugar à constituinte de 1988, que instituiu a democratização e a descentralização do Estado, criando mais um ente federativo, o município, ao qual foi transferido autonomia e responsabilidades sobre processos administrativos e serviço públicos.

Nessas circunstâncias, a descentralização foi defendida tanto em nome da ampliação da democracia quanto do aumento da eficiência do governo e da eficácia de suas políticas. Supunha-se que o fortalecimento das instâncias subnacionais, em especial dos municípios, permitiria aos cidadãos influenciar as decisões e exercer controle sobre os governos locais, reduzindo a burocracia excessiva, o clientelismo e a corrupção (ALMEIDA, 2005).

No entanto, a continuidades dessas práticas no poder público levou a crer que as peculiaridades do arranjo federativo brasileiro estavam muito além da dicotomia centralização x descentralização. Affonso (1995) afirma que a questão central seria entender "qual descentralização e, principalmente, para quê descentralizar". Para o autor, "trata-se de como organizar mais descentralizadamente uma federação assentada sobre tão profundas disparidades regionais mantendo, contudo, articulação, a sua sinergia econômica, social e cultural, que é, em última instância, a sua razão de existir. Embora descentralizada, a nossa Federação ainda não possui um novo perfil e modus operandi definidos, persistindo diversas lacunas ou vazios nas divisões de competências entre as esferas de governo" (op. cit. , p. 68).

A nova constituição determinou com mais clareza as atribuições dos entes federados, e manteve como base a partilha fiscal da constituição anterior, mas certamente com alterações porque incluiu-se os municípios no repasses. Porém, as novas determinações constitucionais de descentralização de poderes ainda não foram 
suficientes para superação dos tradicionais problemas de desequilíbrios verticais e horizontais marcantes da história federativa nacional.

A razão dos desequilíbrios federativos para Prado (2006) ${ }^{64}$ pode estar na ampliação das responsabilidades do Estado, principalmente no campo social, e na duração da crise econômica, que conduziram a um forte aumento da carga tributária e a um certo engessamento no orçamento nacional. Quanto aos estados e municípios, a multiplicação de transferências ficou vinculada a políticas definidas nacionalmente, aumentando a intervenção do governo federal nas decisões dos demais entes com respeito ao uso de recursos orçamentários, limitando as possibilidades de materialização dos benefícios usualmente associados à descentralização fiscal.

Para Affonso (1995), o processo como vem ocorrendo a descentralização, a horizontalização da disputa (entre estados e municípios) e sua generalização são características marcantes do conflito federativo. $\mathrm{O}$ autor defende a existência de uma crise federativa, que teria origens internas e externas. As causas internas estariam na estruturação sócio-econômica nacional e as externas particularmente na globalização, esta agravando ainda mais a desintegração regional pela supressão da escala nacional e negociação direta do exterior com as regiões e cidades, aguçando o espírito competitivo e não cooperativo da federação, e a perda da capacidade articuladora e reguladora da União.

\subsubsection{PNDU de 1975: O pacto federativo e o discurso cooperativo}

Considerando a questão federativa dentro da estratégia geopolítica para a PNDU de 1975, a "proposta" era de manter a autonomia dos municípios na relação com os demais entes. O pacto federativo se efetivaria na articulação dos três entes federativos na criação de condições para implementação dos projetos de infraestrutura, e o desenvolvimento de estudos e projetos para o desenvolvimento urbano, mais especificamente os planos diretores. Essas diretrizes eram traduzidas no discurso oficial por:

• "Apoiar técnica a e financeiramente a institucionalização do
planejamento e a execução dos serviços comuns de interesse

${ }^{64}$ PRADO, Sérgio. Equalização e federalismo fiscal: uma análise comparada. Konrad Adenauer. Rio de Janeiro, 2006 
metropolitano, bem como estimular o planejamento municipal e os programas estaduais de desenvolvimento urbano;

- Adequar a atuação dos órgãos federais às diretrizes do planejamento metropolitano e intra-urbano, particularmente no que diz respeito ao uso do solo;

- Apoiar financeiramente os projetos prioritários de desenvolvimento urbanos e de interesse metropolitano (habitação, saneamento, transportes urbanos, controle de poluição etc.), de acordo com a política nacional de desenvolvimento (MINISTÉRIO DO INTERIOR, 1975, p. 77).

A base dessa cooperação se assentava sobre a idéia da gestão dos "serviços comuns”, principalmente para gestão dos problemas metropolitanos. Para o município, o apoio federal deveria ser dado no estímulo ao planejamento municipal, e aos estados, incentivo aos programas estaduais de desenvolvimento urbano. $O$ planejamento metropolitano deveria receber apoio dos órgãos federais, bem como receber recursos de acordo com as diretrizes da PNDU, para projetos prioritários de desenvolvimento urbano e metropolitano, nas áreas de habitação, saneamento e transportes.

Como fontes de recursos para financiamento de programas e projetos urbanos, contava-se com o FIPLAN e o FINEP, com os Fundos de Desenvolvimento Urbano (do $\mathrm{CEF}, \mathrm{BNH}, \mathrm{BB}, \mathrm{BNB}, \mathrm{BASA})$, do próprio $\mathrm{BNH}$ e das transferências da União aos Estados e municípios. A CNPU era responsável por gerenciar essa gastos públicos, compatibilizando os mecanismos relativos à política financeira e fiscal que, "por sua origem e aplicação no meio urbano, influenciam a qualidade e nível de infra-estrutura econômica e social" (idem, p. 78).

Quanto ao federalismo fiscal, os investimentos nacionais eram distribuídos setorial e regionalmente. Do total de gastos previstos com planos e programas urbanos nas áreas de habitação, saneamento, transportes e outros para o período de 1975 a 79 , do total de $64 \%$ dos recursos foram previstos para a região Sudeste e apenas $16 \%$ para a região Nordeste ${ }^{65}$.

Em que pese o discurso de cooperação, integração governamental, ações conjuntas etc, fato é que o governo federal era o grande formulador, financiador e executor da política urbana, num claro processo de centralização fiscal e administrativa

\footnotetext{
${ }^{65}$ Porcentagens obtidas a partir da previsão de gastos apresentada regionalizados previstos para o BNH, apresentados no documento referencial da PNDU de 1975 (MINISTÉRIO DI INTERIOR, 1975, p. 83, Tabela 6.2)
} 
na implementação da PNDU. Observando-se os resultados, há que se questionar quais fatores concorrem para que um governo centralizado, que formula a política, controla os recursos e meios institucionais para sua execução, não consiga de fato implementar essa política.

Segundo crítica do documento da PNDU DE 2004 sobre as relações federativas anteriores, "para a grande maioria dos municípios, o acesso aos recursos federais se dava sobretudo através de relações de tutela e clientelismo nos diversos ministérios, ao custo de numerosas intermediações políticas e viagens a Brasília ${ }^{66}$. Com baixas taxas de crescimento econômico e indefinição de canais de financiamento para cidades e regiões, ao anos 90 generalizam a chamada 'política de balcão', em que projeto isolados de municípios e estados se submetiam unicamente ao crivo de bancos federais - como Caixa Econômica e BNDES - ou internacionais - como BIRD e BID." (MINISTÉRIO DAS CIDADES, 2004a, p. 36).

\subsubsection{PNDU de 2004: o pacto federativo nas discussões da nova PNDU}

Como já discutido no Capítulo 2, os principais constrangimentos à efetivação do pacto federativo nacional tem-se dado pelas contingências relativas à própria configuração histórica do federalismo no Brasil, que carrega uma "tradição" de disputas intergovernamentais, mais que acordos cooperativos, fato que se agrava quando se trata do arranjo federalista fiscal nacional e no cumprimento das novas competências constitucionais atribuídas a cada ente federativo. A natureza desses constrangimentos e as perspectivas para sua superação têm sido ponto de atenção constante nos debates da nova PNDU.

Nas discussões sobre a PNDU destaca-se a grande preocupação com a criação de condições para ocorrência efetiva do pacto federativo nas políticas urbanas, propondo-se o enfrentamento de problemas como o desequilíbrio regional, a desarticulação entre os entes, e a desarranjo institucional que emperra os processos.

No documento referencial da PNDU, destaca-se a necessidade de uma ação intergovernamental cooperada e coordenada entre os entes federados, principalmente

\footnotetext{
${ }^{66}$ Uma conversa informal com um técnico (arquiteto) de uma prefeitura de cidade média do interior paulista essa mesma situação de muitos recursos para obras locais serem liberadas pelo governo federal por meio de relações pessoais em visitas a Brasília.
} 
na gestão metropolitana e na criação de novos municípios, e claro, nas definições de competências. Apesar dos avanços com o artigo 23 da CF, e das definições do Estatuto das Cidades, reconhece-se que em matéria de cooperação federativa para o desenvolvimento ainda há lacunas que precisam ser preenchidas. $E$ isso implica em: (i) complementar as normas constitucionais sobre as competências federativas, do que é exemplo a Lei dos Consórcios públicos; (ii) ocupar o vazio constitucional caracterizado pela falta de regras claras e marcos regulatórios, em especial no que se refere ao saneamento, transporte urbano, habitação e regularização fundiária, de modo a dar mais segurança aos investimentos e ações; (iii) definir prioridades de ações coordenadas e cooperativas que não dependem obrigatoriamente de legislação, mas de acordos em torno de políticas setoriais.

Na $2^{\text {a }}$ Conferência Nacional das Cidades o debate sobre a Questão Federativa avança, com questões mais complexas de serem trabalhadas, além da Participação e Controle social, da Política urbana regional e metropolitana; e do Financiamento do desenvolvimento urbano. Assim, no texto-base para a $2^{\underline{a}}$ Conferência das Cidades já foram apontadas algumas propostas que possam vir de encontro a essas lacunas observadas:

"10. O desenvolvimento urbano deve ser responsabilidade dos três entes federados, com articulação de orçamentos em projetos acordados e ações coordenadas, respeitando os planos diretores participativos municipais, bem como os planos nacional, regionais e estaduais de ordenamento do território.

11. A PNDU deve propor as diretrizes e explicitar as condições e critérios para a criação, incorporação, fusão e desmembramento de municípios, subsidiando legislação específica para regulamentar o tema.

12. O município deverá ser responsável pelo planejamento, financiamento, gestão, execução e fiscalização das ações do desenvolvimento urbano, com apoio e ação subsidiária dos estados e da União.

13. A ação subsidiária dos estados e da União no financiamento e execução do desenvolvimento urbano deve ser baseada em indicadores que meçam a capacidade dos municípios de gerar riquezas frente às carências e demandas dos mesmos nas questões de moradia, saneamento ambiental; mobilidade e ocupação e uso do solo; assim como sua inserção regional e posição na rede de cidades.

14. A cooperação e a coordenação intergovernamental de programas, projetos e ações devem ser priorizadas. A parceria é fundamental para o desenvolvimento urbano, especialmente nas bacias hidrográficas, nas microrregiões pouco dinâmicas, nas aglomerações urbanas e nas regiões metropolitanas, onde os grandes problemas urbanos dependem de gestão compartilhada e cooperação administrativa.

15. A União deve formular e aprovar leis que possam definir competências dos diversos entes federados na gestão, ordenamento e desenvolvimento do território urbano.

16. União, estados, Distrito Federal e municípios devem utilizar o Consórcio Público como forma de fortalecer a cooperação federativa e 
promover parcerias para a gestão de serviços públicos" (MINISTÉRIO DAS CIDADES, 2008a).

$\mathrm{Na} 2^{\underline{a}}$ Conferência, as proposições principais giram em torno da responsabilização dos três entes sobre o desenvolvimento urbano, mas tendo o município como principal executor dessa política, contando com subsídios dos estados e da União na implementação dessas ações. A parceria e a cooperação são estimuladas, principalmente com a utilização da lei de Consórcios Públicos.

Nas resoluções da $3^{a}$ Conferência Nacional das Cidades, as discussões em torno da questão federativa avançam um pouco mais, propondo-se a "definição de um pacto entre os entes federados para implantação da Política Nacional de Desenvolvimento Urbano (PNDU), com os seguintes papéis:

- União - financiamento, formulação das diretrizes nacionais e avaliação dos resultados.

- Estados - financiamento, fomento para elaboração, monitoramento e avaliação dos planos estaduais e regionais.

- Municípios - financiamento, formulação, monitoramento e avaliação das diretrizes locais e implementação das ações, com adequação aos planos regionais e aos planos diretores participativos" (MINISTÉRIO DAS CIDADES, 2008b).

Verifica-se que o Ministério das Cidades tem concentrado esforços nessa direção, fomentado a ação conjunta e integrada das esferas de governo - federal, estadual e municipal, juntamente com a participação e mobilização da sociedade, na intenção de garantir condições para efetivação do "direito à cidade" - moradia, saneamento, equipamentos público, à parcela de excluídos do desenvolvimento urbano.

Teoricamente, esse deveria ser o grande diferencial nesse processo político - a busca da pactuação federativa e democrática - mas na prática, o que se tem observado é ainda a grande dificuldade de se colocar as proposições resultantes do processo democrático em prática, no sentido de efetivação em políticas e programas que fujam dos velhos problemas da falta de integração, da setorialização e de se articular políticas nos três níveis de governo.

O atual governo tenta pôr em pauta uma agenda federativa que permita estabelecer relações mais estreitas no compartilhamento de "issues" de interesse 
comum. Assim, o que tem sido chamado de "Agenda Federativa Compartilhada", estabelecida desde 2007, tem como objetivos

- Consolidar uma ampla rede pública de proteção social, mediante o fortalecimento e a integração das políticas públicas federativas, como as de Educação, Saúde, Assistência Social, Trabalho e Renda, Cultura, Segurança Pública, Regularização Fundiária e as demais políticas de desenvolvimento urbano (habitação, saneamento e mobilidade urbana);

- Pactuar uma agenda estratégica para as regiões metropolitanas, de modo a superar a fragmentação da ação governamental nesses territórios, viabilizar a gestão democrática e ambientalmente sustentável das cidades, a integração das políticas de desenvolvimento urbano com as estratégias de combate à violência, além do acesso de toda a população aos serviços públicos e à infra-estrutura urbana

- Desenvolver uma política nacional de fortalecimento institucional e gerencial dos municípios, articulando os diversos programas de capacitação, apoio e fortalecimento da gestão municipal desenvolvidos pelos órgãos federais, com foco nos pequenos municípios, bem como promovendo o aperfeiçoamento da legislação nacional de contabilidade pública, responsabilidade fiscal, licitações e contratos, entre outros;

- Ampliar e qualificar o padrão de atendimento dos órgãos federais aos municípios, viabilizando o acesso aos programas e recursos federais de forma transparente e desburocratizada

- Fortalecer os mecanismos de negociação, pactuação e cooperação federativa, mediante a institucionalização de instâncias intergovernamentais, como o Comitê de Articulação Federativa ${ }^{67}$, comissões tripartites e mesas federativas, e pela regulamentação dos dispositivos constitucionais pertinentes (arts. 18, 23 e 43 entre outros)

- Apoiar as ações da cooperação internacional federativa e descentralizada, como o Foro de Governadores e Prefeitos do Mercosul, as ações de cooperação para o desenvolvimento regional nas fronteiras e relações bilaterais dentro dos acordos-quadro internacionais, além das iniciativas internacionais das associações nacionais municipalistas ${ }^{68}$.

O discurso ministerial da pactuação federativa, da cooperação, da transversalidade, participação democrática, da cidade justa e igualitária etc se coloca como prática ainda difícil se transpor em políticas exeqüíveis de fato. Se antes as políticas eram clientelísticas, populistas, elitistas e economicamente enviesadas, elas

\footnotetext{
${ }^{67}$ Por meio do decreto no 6.181/2007, foi instituído o Comitê de Articulação Federativa - CAF, no âmbito da Secretaria de Relações Institucionais da Presidência da República, com a finalidade de promover a articulação na formulação de estratégias e implementação de ações coordenadas e cooperativas entre as esferas federal e municipal de governo, para atendimento das demandas da sociedade e aprimoramento das relações federativas."

Propostas do Comitê de Articulação Federativa, do Governo Federal. Disponível em: http://www.portalfederativo.gov.br/bin/view/Inicio/WebHome. Acesso em: 05.05.2008. Segunda consta ainda na página de assuntos federativos do GF, "no âmbito do CAF já foram criados seis grupos de trabalho interfederativos, com o objetivo de debater e para prestação do serviço de transporte escolar; de ações de fortalecimento institucional e qualificação da gestão dos municípios; de acompanhamento das ações do Plano de Desenvolvimento da Educação (PDE) e para o desenvolvimento de alternativas para o barateamento das tarifas e melhoria da qualidade dos serviços de transporte público urbano; e para o aperfeiçoamento da gestão das Regiões Metropolitanas, Aglomerações Urbanas e Microrregiões".
} 
agora se revestem de novos atores, novas burocracias, novas práticas econômicas liberalizantes e globalizantes, novos conflitos federativos que exigem uma revisão constante dos padrões que regem os processos de tomada de decisão.

\subsubsection{Considerações sobre a competência comum e a difícil cooperação intergovernamental}

A instituição da república federativa no Brasil configurou a distribuição de poderes entre a União, os Estados, e mais recentemente os Municípios, tornando-se um marco na natureza das relações políticas e econômicas entre esses entes nas diversas esferas de atuação do poder público.

Umas dessas esferas é o processo de tomada de decisões sobre políticas públicas que, somado aos contingenciamentos históricos que têm conformado o federalismo nacional, tornou-se mais complexo diante das combinações de poderes, responsabilidades, recursos e interesses - internos e externos - afetando diretamente a formulação e execução de políticas para o enfrentamento dos problemas urbanos a partir de meados do século XX, uma vez que o "pacto federativo", que se define e se consubstancia pela cooperação e articulação entre os entes federativos, é constantemente ameaçado pelos conflitos de interesses entre o governo central e os governos subnacionais, e pelas próprias especificidades do arranjo federativo nacional.

Relembrando a trajetória das Políticas Nacionais de Desenvolvimento Urbano no Brasil verificam-se dois momentos políticos distintos relativos ao arranjo federativo: a primeira, proposta em 1975, foi elaborada num contexto de centralização política ditatorial, de tomadas de decisões unilaterais pelo governo federal e seus órgãos. Já a segunda experiência, mais recente, de 2004, num contexto de descentralização e democratização dos processos decisórios, vem sendo elaborada num amplo processo de articulação e debates, não só entre União, estados e municípios, mas entre o executivo e os demais poderes e com a sociedade.

São dois cenários bem distintos que, se analisados sob a ótica do pacto federativo, podem agregar elementos para se entender o quadro de correlações que se insere a política urbana atual e do passado. Não se pretende justificar a crise urbana pela crise federativa, mas por meio da verificação de como a política é afetada pelos arranjos institucionais, as preferências de burocracias e os mecanismos legais da organização federativa do país. 
"O federalismo brasileiro enquanto instituição tem sido moldado por arranjos políticos e territoriais construídos ao longo da nossa história. Esses arranjos se refletiram em cada uma das constituições brasileiras, mostrando que as relações federativas têm se movido através de um continuum, que saiu de um federalismo "isolado" dos primeiros anos republicanos para a centralização nos regimes autoritários, até chegar à sua atual configuração, onde o poder entre os entes constitutivos da Federação e das instituições a eles relacionados encontra-se mais equilibrado" (SOUZA, 2003, p. 143).

Nas décadas mais recentes, ao se expressar legalmente as responsabilidades de União, Estados e municípios sobre a política urbana, intensificou-se o debate sobre a capacidade do federalismo brasileiro, combinado a outras contingências da organização política nacional, ser um fator de articulação ou entrave ao processo de gestão urbana.

A descentralização federativa constitucionalmente fortalecida desde o final da década de 1980 redefine o pacto federativo no tocante às competências de União, Estados e municípios. Finalmente colocada na agenda política nacional com a constituição de 1988, a política urbana passa a ser formulada mediante a proposição de leis por diferentes atores institucionais, conforme as competências legislativas definidas na constituição. Na prática, a questão de coordenação para soluções de problemas urbanos encontra-se mais próximo de um "imbróglio" que de um pacto propriamente dito, tanto pelas indefinições de competências, quanto pelo complexo trâmite de criação de políticas dentro do sistema federativo.

A PNDU de 2004, além de contar com as mudanças constitucionais de 1988, também tem no Estatuto da Cidade de 2001 as definições legais sobre os papéis dos entes federativos. Segundo o Estatuto, no seu artigo $3^{\circ}$, as competências da União sobre a política urbana tomam como base a repartição das competências constitucionais sobre essa política atribuída aos entes federativos, mas deixa lacunas que precisam ser mais precisamente definidas, principalmente na forma de negociação legal e institucional para que o pacto federativo ocorra de fato. Destaca-se nas proposições para a nova PNDU a grande preocupação com a criação de condições para ocorrência efetiva do pacto federativo nas políticas urbanas, propondo-se o enfrentamento de problemas como o desequilíbrio regional, a desarticulação entre os entes, e a desarranjo institucional que emperra os processos. 
Na PNDU de 1975 pode-se dizer que havia uma alta concentração de poderes nas mãos do governo central. Essa lógica se repete no tratamento da questão espacial urbana e nas definições estratégicas de políticas para ordenamento do território nacional. SOUZA (2004, p. 141) aponta como uma das divergências da I PNDU o antagonismo entre as diretrizes da política urbana, de caráter eminentemente descentralizador - da sociedade e do espaço - e as diretrizes do II PND, de caráter centralizador. A proposta na PNDU de 1975 era de manter a autonomia dos municípios, mas ficava evidente a centralização de decisões e ações de iniciativa do governo federal.

Devido às idéias geopolíticas de poder da nação, soberania nacional, era dominante a associação a um Estado forte, capaz de decidir os rumos do desenvolvimento do País, e obviamente do desenvolvimento urbano (mais regional que intra-urbano). As políticas federais prevaleciam comandadas pelos militares, pela burocracia e pelos agentes privados e coronéis, engajados em um projeto de "integração" no discurso, mas na prática de retalhação do território e da cidade, cada qual interessado em assegurar que seus interesses sejam contemplados nos planos, programas e projetos do Estado para a cidade e para as regiões.

Testemunho patente disso é o processo de elaboração da primeira política nacional de desenvolvimento, em que se privilegiavam os planos de investimento nas regiões de maior concentração econômica e industrial, mas com a abertura de estradas, provimento de energia e outras ações nas regiões norte e centro-oeste como novos focos de investimentos do capital privado. Isso se reproduzia não somente em escala regional, como também local, intra-urbana, onde os recursos públicos, como os destinados ao financiamento da habitação, privilegiavam a classe média, enquanto 0 provimento de moradia para a as populações de renda mais baixa limitavam-se a terras não urbanizadas e projetos arquitetônicos sem adequação mínima para uma moradia digna.

Para Villaça (2004, p. 190),

"o fato de a técnica no período ditatorial legitimar a ação do Estado marcou profundamente o planejamento urbano que foi concebido segundo planos setoriais, regionais e nacionais, para justificar obras que eram ou tinham intenção de serem executadas, e os planos urbanos equivalentes aos planos diretores - que de um enorme calhamaço de documentações diversas, mapas, pesquisa, estatísticas etc, passou a projeto de lei, muitas vezes apenas com declarações de princípios ou diretrizes." 
Prevaleciam os planos diretores de âmbito local como instrumentos de planejamento "intra-urbano", elaborados segundo as demandas da alta renda e interesses dos agentes privados. Muitos desses planos não tiveram uma força executiva de fato, tornando-se meramente "planos de gaveta", aproximando-se mais de instrumentos técnicos e normativos, muitas vezes desconexos da realidade urbana, que tinham pouco ou nenhum rebatimento no desenvolvimento das cidades e na melhoria efetiva da qualidade de vida da sociedade. O sentido da cooperação federativa no desenvolvimento urbano e regional ficou apenas no vácuo, ou melhor, no papel.

Segundo Maricato (2006, p. 212), "a falta de tradição federativa constitui um forte constrangimento para a solução de problemas urbanos. O desprestígio da esfera pública dificulta a cooperação entre diversos governos de um mesmo nível ou governos de diversos níveis. Um exemplo expressivo dessa assertiva está na falta de instâncias satisfatórias de gestão de regiões metropolitanas, embora o país tenha algumas das maiores metrópoles do mundo". O entendimento é de que a atual constituição consagrou o federalismo, mas não foi capaz de criar uma estrutura institucional e política que respaldasse os entes federados frente aos novos encargos administrativas e fiscais que the foram designados (NATAL, 1996).

Segundo Prado (2006) , mesmo diante desses desafios, a federação brasileira parece ainda não ter despertado para a importância de promover os ajustes necessários no federalismo fiscal brasileiro: "ao mesmo tempo em que a política tributária das ultimas décadas foi dominada pelas preocupações com a dimensão macroeconômica do ajuste fiscal, os fundamentos em que se apoiava o modelo fiscalfederativo adotado na Constituição de 1967 foram sendo abandonados. As diversas mudanças promovidas na transição do regime autoritário para a democracia na década de oitenta, agravadas pelas alterações incluídas na Constituição de 1988 e mudanças posteriores, reverteram a descentralização tributária, esvaziaram a base das transferências constitucionais e destruíram os mecanismos financeiros voltados para a cooperação intergovernamental na promoção das políticas nacionais de desenvolvimento".

Como já se observou anteriormente, essa situação tornou-se institucionalizada e constitucionalizada a partir de 1988. Desde então, o que se tem visto é uma disputa entre União, Estados e municípios por recursos tributários, fato agravado pelas regras 
definitivas ainda pendentes de regulamentação constitucional. Por outro lado, definidas constitucionalmente, as despesas estão atreladas às atribuições cabíveis a cada nível de governo, porém, são deixadas brechas, principalmente quando se fala em competências concorrentes, onde há possibilidade de mais de um ente federado responsabilizar-se sobre o assunto.

Isso impacta diretamente nas políticas públicas, uma vez que o gasto gerado a partir da execução de políticas urbanas, sociais, etc, onera deveras o orçamento do ente responsável, abrindo brechas para um "jogo de empurra", no que carece de determinação constitucional. Conforme constata Almeida (2005), "com efeito, a concentração de recursos fiscais na esfera federal foi a marca do autoritarismo burocrático no Brasil. Dessa forma, no Brasil pós-autoritário, a redefinição de competências e atribuições entre esferas de governo disse respeito sobretudo - ainda que não exclusivamente - às políticas e programas sociais. É aqui, portanto, que os dilemas envolvidos no processo podem ser observados com mais clareza".

Um elemento mais recente, de grande impacto sobre o funcionamento do federalismo brasileiro foi a LRF - Lei de Responsabilidade Fiscal, aprovada em 2000 (COSTA, 2007), que estabeleceu normas rígidas para todos os governos, inclusive o federal. Se por um lado a LRF preserva os entes federados do gasto irresponsável, contendo o endividamento, por outro lado, tem funcionado como um elemento de contenção dos gastos públicos, o que é importante, mas também de investimentos em setores urbanos básicos, como a de habitação e saneamento, por exemplo. Além disso, as disputas horizontais se expressam nas "guerras fiscais", procurando utilizarse de meios fiscais para atrair investidores e obter maior arrecadação via ICMS. Diante dessas restrições orçamentárias, União, Estados e Municípios precisam constantemente de ajustes em seus orçamentos de forma a arcar com os custos das políticas que são de responsabilidade.

A falta de clareza ou as determinações de responsabilidades e atribuições concorrentes entre os entes é o grande questionamento de como fazer funcionar esse pacto fiscal-federativo. Para Rezende (1995, p. 244) "na ausência de fatores propícios à articulação e coordenação das decisões de investimento, predominam a pulverização, o casuísmo e o clientelismo facilitados pela dispersão dos recursos em vários centros de decisão, cada um deles comandando uma verba insuficiente para viabilizar empreendimentos de maior porte, porém capaz de angariar apoio político em 
troca do suporte financeiro para a realização de pequeno vulto com grande visibilidade eleitoreira e escasso impacto na economia e na sociedade".

Pinto (2007) lembra que as políticas urbanas demandam investimentos de longo prazo e apresentam um desenho complexo, exigindo uma acurada cooperação intergovernamental e coordenação de ações de interesses comuns. Porém essa autora aponta que a rigidez fiscal tem dificultado a iniciativa, principalmente de União e estados, de mecanismos de cooperação, principalmente sobre a infra-estrutura urbana, de competência dos municípios. No interurbano ou inter-regional, o imbróglio político da gestão metropolitana é um problema patente e crescente, e as disparidades interregionais tornam ainda mais difíceis a cooperação federal, com o que, segundo a autora, "o arcabouço institucional do federalismo brasileiro tem-se mostrado inadequado para lidar".

Muitas dessas questões urbanas que tem se relacionado diretamente com o federalismo fiscal, como o regionalismo e o municipalismo, carecem de intervenções claras do governo federal em termos de reformas políticas e criação de políticas urbanas nacionais, o que só em décadas mais recentes entrou como pauta na agenda do governo federal. O municipalismo tem sido fortalecido com a descentralização da execução das políticas urbanas, e as disparidades inter-regionais, acentuadas cada vez mais com os desequilíbrios econômicos e fiscais.

Tomando como base as análises de MacDOWELL (2007) sobre o financiamento urbano, em particular a situação dos municípios, os problemas fiscais se apresentam da seguinte forma:

i. Problemas para aquisição de empréstimos (instrumentos de controle às vezes fora do alcance de alguns municípios) - A complexidade dos procedimentos burocráticos exigidos pelas instituições financiadoras é apontada pelos governos locais como um fator limitador para a tomada de empréstimos, uma vez que a execução de determinadas política urbanas exige mais recursos do que pode ser conseguido via receitas correntes;

ii. São muitos municípios pra repartir a receita (mais ou menos resolvido em 1996)

iii. $\quad$ governo federal acabou por criar novas contribuições sociais desvinculadas dos fundos com repasse aos governos subnacionais- "E quais as conseqüências do retorno das transferências vinculadas sobre as finanças municipais? O principal impacto, sob o ponto de vista do governo local, é a redução do poder discricionário dos governos locais quanto à alocação dos recursos. A destinação dos recursos, nesses casos, é decidida pelo governo federal, de acordo com prioridades da sua política de desenvolvimento nacional." 
iv. Atuação de forma não planejada e descoordenada dos municípios no desempenho de algumas funções urbanas e sociais devido à ausência de definição legal dos responsáveis (competências dos entes federativos);

v. Subaproveitamento do potencial de arrecadação do IPTU;

vi. As transferências fiscais dos governos federal e estaduais na composição da receita corrente que gera alta dependência dos municípios;

vii. Municípios com mais habitantes dispõem de menos receita para despesas;

viii. $\quad$ Pressão da população pela oferta de serviços urbanos;

ix. Pequenos municípios sofrem pela falta de economias de escala (uma atividade econômica que gere receita para o município);

x. Grandes municípios, como São Paulo, já sofrem com a deseconomia de aglomeração, que é a saída da atividade econômica para regiões com maior atratividade (menos custos);

xi. O processo de democratização gerou maior pressão da população para o atendimento aos serviços públicos, que com a descentralização passaram a ser atendidos muito mais pelos municípios, que pelos estados e governo federal, que passaram a se acomodar na oferta desses serviços;

xii. Discrepâncias de arrecadação do IPTU por habitante mesmo entre municípios com indicadores semelhantes de renda e tamanho da população;

xiii. Poder discricionário dos municípios em relação a algumas receitas, mas restrito em outras, gerando uma autonomia restrita

xiv. A dependência dos municípios das transferências intergovernamentais gera uma incerteza das receitas, e isso impacta diretamente na previsibilidade do orçamento municipal" (MacDOWELL, 2007)

Nestas situações em particular se estabelece uma relação concreta da interferência do sistema federativo sobre as políticas urbanas: a centralização e concentração de poderes de tomada de decisões, a quebra do pacto federativo, pela falta de cooperação entre os entes federativos; a guerra fiscal, com as disputas entre os governos para arrecadação; a falta de clareza das competências; o processo de criação da política urbana, que passa por negociações diversas e pressões dos diversos grupos de atores desde a sua formulação até sua implementação.

Como visto, são muitos os fatores que concorrem dentro do pacto federativo nacional na convergência com as políticas urbanas. Viu-se que a tentativa de pactuação entre os diversos níveis de governos, principalmente após a constituição de 1988, tem elementos interferentes os mais diversos, como a descentralização, a democratização, a redefinição de competências, a redistribuição de recursos e o próprio redesenho da política urbana.

Dentre estes, a redefinição de competências na formulação e execução das políticas de desenvolvimento urbano tem um peso significativo para a factibilidade do que ficou constitucionalmente desenhado. A formulação em nível nacional e a 
execução nos demais níveis de governo, principalmente municipal, têm revelado o grau de dificuldade que esse redesenho apresenta.

A redistribuição de competências entre os entes federados exige uma movimentação conjunta e concertada entre essas esferas na criação e implementação de políticas, programas e ações nas cidades, que muitas vezes se vêem limitadas por um fraco arranjo institucional que dê suporte a essa articulação federativa. Para Natal (1996), o redesenho do Estado é um aspecto decisivo nos debates sobre as atribuições de competências e funções entre os entes federativos. Segundo esse autor, há um consenso de que o antigo Estado desenvolvimentista exauriu-se, mas acredita que não se efetivou ainda uma pactuação federativa que assegure um processo estratégico nacional de desenvolvimento. No nível federal, apesar do seu papel decisivo, observase o enfraquecimento do papel coordenador e regulador do Estado. 


\section{Capítulo 4}




\section{$\mathbf{C}_{\text {APITULO } 4}$}

\section{EIXOS COMPARATIVOS - Instrumentos}

Esse capítulo dedica-se à comparação das Políticas de Desenvolvimento Urbano relativamente a seus instrumentos, enquanto aparatos institucionais, financeiros, legais e técnicos, categorização, usada por Serra (1991, p. 85) para designar instrumentos da Política de Desenvolvimento Urbano que se mostram adequadas para apresentar as duas PNDUs em bases comparáveis.

Sendo assim, os instrumentos institucionais serão relativos à estrutura do governo federal, às relações governamentais e competências dos governos, enfim, às estruturas que interferem no processo de tomada de decisões e na implementação das políticas. Os instrumentos financeiros tanto se referem ao federalismo fiscal, que determina as partes de arrecadações e tributos para cada ente federado, como os recursos disponibilizados para a implementação dos programas. Os instrumentos legais referem-se à legislação urbanística de suporte às PNDUs e os instrumentos técnicos de capacitação das equipes técnicas dos governos para dar suporte à implementação das diretrizes das políticas.

\subsection{INSTRUMENTOS INSTITUCIONAIS}

A verificação da estrutura institucional no contexto das políticas de desenvolvimento apresenta algumas possibilidades. Uma possibilidade é fazer uma abordagem a partir da estrutura institucional de suporte à implementação da Políticas, verificando os órgão competentes. Outra possibilidade é verificar como o sistema institucional de momento, enquanto conjugação de regras e atores, tem a capacidade de ter aprovadas "mudanças" que impliquem em avanços na consecução das diretrizes da Política.

Isso implica na conjugação de três temas que já têm sido tangenciados ao longo dessa tese: as competências dos governos, as relações governamentais e participação dos atores nos processos de tomada de decisão. 
O processo de iniciativa, criação, aprovação, liberação de recursos e execução, dessas e de outras políticas, passa por instâncias diversas implicando na necessidade de uma movimentação conjunta e concertada entre esferas de poder político e atores na criação e implementação de políticas, programas e ações para as cidades.

O processo de iniciativa, criação, aprovação, liberação de recursos e execução de políticas públicas, passa momentos diversos: a percepção da necessidade de mudança de certo status quo por um grupo, a proposição de uma reforma, os contextos e mecanismos institucionais que podem ou não favorecer o avanços dessa proposição, o embate de grupos políticos, a proposição de uma lei, os trâmites institucionais de aprovação dessa lei, a momento adequado de "ocupação" das arenas e a combinação de articulações e mecanismos para sua aprovação, os novos instrumentos necessários para implementação, enfim, há uma combinação de regras institucionais, atores e arenas de veto até à consecução dos objetivos de mudança.

Mediante esse complexo processo, verifica-se que as instituições e atores no sistema federativo têm interferência direta no processo de criação e implementação das políticas urbanas, sendo essencial a compreensão desse sistema de relação entre os governos, ou seja, a sua competência para legislar, elaborar políticas e planos, implementar programas ou gerir serviços

\subsubsection{Relações governamentais e competências dos governos}

As competências entre os governos, divididas em materiais (administrativas) exclusivas e comuns, e as competências legislativas (regulamentar matérias por lei), divididas quanto à iniciativa em exclusiva, privativa, concorrente e suplementar. Segundo explicam Baracho Jr. e Lima (2007, p. 4):

"Diz-se que a competência é exclusiva quando é atribuída a uma entidade com exclusão das demais, sem possibilidade de delegação (transmitir o poder). Competência privativa, àquela enumerada como própria de uma entidade, podendo, contudo ser delegada a outra. Competência comum significa legislar ou praticar atos em pé de igualdade com outros, sem que o exercício de uma venha a excluir a competência de outra. Competência concorrente é a possibilidade de dispor sobre o mesmo assunto ou matéria por mais de uma entidade federativa. Podendo ser plena, no âmbito de seu território, quando 
inexistir legislação federal; ou suplementar, quando as normas supram ausência ou omissão de determinado ponto da norma geral nacional, ou desdobrem seu conteúdo visando atender peculiaridades locais. Sempre a legislação federal terá primazia sobre as elaboradas concorrente ou suplementarmente pelas outras unidades da federação."

Em resumo, nas competências legislativas comuns os três entes podem legislar sobre o assunto, enquanto nas concorrentes, a União tem competência para estabelecer normas gerais que podem ser complementadas por legislação estadual. $\mathrm{Na}$ ausência de legislação federal, os Estados exercem competência legislativa plena. A competência residual também é dos Estados.

Com relação às responsabilidades sobre as questões urbanas, as competências materiais e legislativas de cada ente federado ficaram assim estabelecidas segundo a Constituição de 1988: a União - Artigo 20, inc. IX - deve "elaborar e executar planos nacionais e regionais de ordenação territorial e de desenvolvimento econômico" - e no XX - "instituir diretrizes para o desenvolvimento urbano, inclusive habitação, saneamento básico e transportes". Os Estados - Artigo 25, parágrafo $3^{\circ}$ - "poderão, mediante lei complementar, instituir regiões metropolitanas, aglomerações urbanas e microrregiões, constituídas por agrupamento de municípios limítrofes, para integrar a organização, o planejamento e a execução de funções públicas de interesse comum". E os municípios - no Artigo 30, inciso VIII - promover, no que couber, adequado ordenamento territorial, mediante planejamento e controle do uso do solo, do parcelamento e da ocupação do solo urbano". O Quadro 7 demonstra a distribuição de competências entre os entes federativos.

\section{Quadro 5 - Distribuição das competências dos entes federativos}

\begin{tabular}{|c|c|c|c|}
\hline $\begin{array}{l}\text { ENTE } \\
\text { FEDER. }\end{array}$ & $\begin{array}{l}\text { AREA DE } \\
\text { ATUAÇÃO }\end{array}$ & $\begin{array}{l}\text { COMPETËNCIAS LEGISLATIVAS } \\
\text { (ref. ao desenvolvimento urbano) }\end{array}$ & $\begin{array}{l}\text { COMPETËNCIAS } \\
\text { MATERIAIS } \\
\text { (ref. ao desenvolvimento } \\
\text { urbano) }\end{array}$ \\
\hline UNIÂO & $\begin{array}{l}\text { Nacional } \\
\text { Regional } \\
\text { Municipal }\end{array}$ & $\begin{array}{l}\text { Exclusivas } \\
\text { • desapropriação } \\
\text { - } \quad \text { diretrizes da política nacional de transportes } \\
\text { • } \quad \text { trânsito e transporte; } \\
\text { questões específicas das matérias relacionadas neste artigo } \\
\text { Comuns } \\
\text { • impedir a evasão, a destruição e a descaracterização de obras } \\
\text { de arte e de outros bens de valor histórico, artístico ou cultural } \\
\text { - proteger o meio ambiente e combater a poluição em qualquer } \\
\text { de suas formas } \\
\text { - preservar as florestas, a fauna e a flora } \\
\text { • construção de moradias e a melhoria das condições } \\
\text { habitacionais e de saneamento básico } \\
\text { • Lei complementar fixará normas para a cooperação entre a } \\
\text { União e os Estados, o Distrito Federal e os Municípios, tendo em } \\
\text { vista o equilíbrio do desenvolvimento e do bem-estar em âmbito } \\
\text { nacional. }\end{array}$ & $\begin{array}{l}\text { Pela Lei federal de } \\
\text { desenvolvimento urbano: } \\
\text { - dar diretrizes de } \\
\text { desenvolvimento urbano } \\
\text { - definir objetivos da } \\
\text { política urbana nacional } \\
\text { - regulamentar os artigos } \\
182 \text { e } 183 \text { da Const. } \\
\text { - instituir os instrumentos } \\
\text { urbanísticos } \\
\text { - sistema de gestão da } \\
\text { política nacional } \\
\text { - Planos nacionais e } \\
\text { regionais de ordenação do } \\
\text { território e desenvolvimento } \\
\text { econômico e social }\end{array}$ \\
\hline
\end{tabular}




\begin{tabular}{|c|c|c|c|}
\hline $\begin{array}{l}\text { ENTE } \\
\text { FEDER. }\end{array}$ & $\begin{array}{l}\text { AREA DE } \\
\text { ATUAÇÃO }\end{array}$ & $\begin{array}{l}\text { COMPETENCIAS LEGISLATIVAS } \\
\text { (ref. ao desenvolvimento urbano) }\end{array}$ & $\begin{array}{l}\text { COMPETENCIAS } \\
\text { MATERIAIS } \\
\text { (ref. ao desenvolvimento } \\
\text { urbano) }\end{array}$ \\
\hline $\begin{array}{l}\text { ESTADOS E } \\
\text { DISTRITO } \\
\text { FEDERAL }\end{array}$ & $\begin{array}{l}\text { Metropolitana } \\
\text { Microrregional } \\
\text { Estadual } \\
\text { Municipal }\end{array}$ & $\begin{array}{l}\text { Concorrentes (com a União) } \\
\text { - Direito urbanístico } \\
\text { - florestas, caça, pesca, fauna, conservação da natureza, } \\
\text { e controle da poluição; } \\
\text { - proteção ao patrimônio histórico, cultural, artístico, turístico e } \\
\text { paisagístico } \\
\text { a responsabilidade por dano ao meio ambiente, ao consumidor, } \\
\text { paisagístico; }\end{array}$ & $\begin{array}{l}\text { Pela Lei estadual de } \\
\text { política urbana (na } \\
\text { ausência de federal) } \\
\text { - sistema de política urbana } \\
\text { metropolitana }\end{array}$ \\
\hline MUNICIPIOS & $\begin{array}{l}\text { Municipal } \\
\text { Local }\end{array}$ & 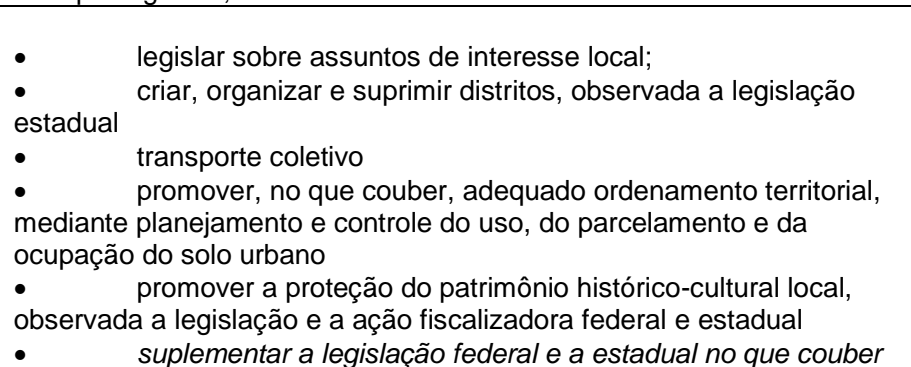 & $\begin{array}{l}\text { Pela Lei orgânica } \\
\text { Pelo Plano diretor } \\
\text { - Legislar sobre assuntos } \\
\text { de interesse local } \\
\text { - planejamento e controle } \\
\text { do uso, ocupação e } \\
\text { parcelamento do solo } \\
\text { urbano }\end{array}$ \\
\hline
\end{tabular}

Fontes: SOUZA (2003), PÓLIS (2001), BARACHO Jr. e LIMA (2007)

A grande dificuldade nesta área está nas competências concorrentes. Como afirma Martins (2004) "apesar de haver competências exclusivas, o que predomina na estrutura brasileira são as competências concorrentes - no que o nível estadual é o mais inespecífico. As poucas competências exclusivas são referentes à União e aos Municípios. Aos Estados, compete tudo que não Ihes seja vedado pela Constituição."

Como a autora mesmo afirma isso tem gerado tensões principalmente entre Estados e Municípios, que tem sua área de atuação em termos de políticas e legislações ampliadas, como também transferências diretas vinculadas, como da área de saúde, educação e assistência social, além de maior possibilidade de fazer parcerias e receber investimentos externos.

Já em termos de prestação de serviços públicos, os conflitos aumentam por conta das competências concorrentes, que permitem que mais de um dos entes tenha prerrogativas de prestação do mesmo serviço que os demais, como confima Lordello de Mello:

"Nós temos no Brasil um sistema profundamente estranho e nefasto de competências concorrentes, segundo o qual um mesmo serviço público, inclusive aquele de caráter predominantemente local, pode ser prestado diferente e simultaneamente pelo Estado e até pela União. Esse sistema é ilógico em todos os sentidos e, se fosse bom, de 175 países não seria 0 Brasil o único a adotá-lo, (Lordello de Mello, citado por SERRA, 1991, p. $51)$. 
Assim, por exemplo, sofrem claramente com essas sobreposições ou lacunas de competências as regiões metropolitanas. A questão das regiões metropolitanas é sempre um ponto nevrálgico ao se tratar das relações federativas, uma vez que a criação de mais uma instância governativa, que depende da articulação e cooperação de diversos entes federados pode se tornar mais um imbróglio do que uma saída, uma vez que enfrentam, além dos problemas intergovernamentais até então levantados, a não consolidação ainda como uma instância governativa de fato, embora seja constantemente utilizada como objeto de pesquisa, por concentrar os principais problemas urbanos nacionais.

\begin{abstract}
"Passadas poucas décadas da institucionalização da gestão metropolitana no Brasil, a maioria das experiências foi interrompida nos anos 90, gerando algumas perguntas que ainda buscam respostas, em especial para dois conjuntos de questões. O primeiro se reporta à compreensão de por que as RMs perderam espaço na agenda política quando o processo de redemocratização se iniciou e por que a maioria das entidades estaduais criadas para geri-las não sobreviveu à redemocratização. O segundo diz respeito ao papel das $\mathrm{RMs}$ no sistema federativo brasileiro e nas relações intergovernamentais, enfatizando, sobretudo, a questão da cooperação (ou da falta de cooperação) entre entes governamentais. Tais questões tornam-se ainda mais importantes porque o tema metropolitano (ou o das grandes cidades) e o da sua gestão, silenciado nos anos 90, começa, lentamente, a ressurgir na agenda pública, embora ainda restrito aos fóruns acadêmicos e técnicos" (SOUZA, 2003, p. 138)
\end{abstract}

\title{
4.1.2. A estrutura institucional da PNDU de 1975: a subordinação federativa
}

Como já debatido em alguns momento, o contexto da PNDU de 1975 era marcadamente centralizador e concentrador de decisões por parte do governo federal;:

A estrutura institucional disposta para implementação das diretrizes da PNDU, baseava-se no entendimento da necessidade de institucionalização da atividade do planejamento $^{69}$ como forma de garantir, primeiramente a sua existência, e

\footnotetext{
${ }^{69}$ Cintra (1978) afirma que "os arquitetos-planejadores", muitas vezes alocados em órgãos burocráticos eram os maiores incentivadores da "institucionalização" do planejamento urbano, via construção da política nacional de desenvolvimento urbano. Na década de 1960, estavam à frente do movimento de promoção do planejamento urbano, arquitetos-planejadores, muitos deles colocados nos próprios órgãos governamentais. A atividade de planejamento relacionada a sistemas urbanos, principalmente em nível local, foi incentivada entre profissionais de diversas áreas (arquitetos, economistas, administradores, principalmente, mas também geógrafos e sociólogos), constituídos em grupos privados, mas vinculados ao setor público quando contratados pelas prefeituras para a execução dos planos.
} 
posteriormente a implementação da política nacional de desenvolvimento urbano pelo governo central, a partir de seus órgão ou agências criadas.

A "institucionalização do planejamento" e a estrutura organizacional criada alinhava-se às expectativas do governo federal de manter cada vez mais controle sobre os processos decisórios na determinação das diretrizes do desenvolvimento urbano, até mesmo como forma de ingerência sobre Estados e municípios.

A Lei 4.380 instituiu o Serviço Federal de Habitação e Urbanismo (SERFHAU) e o $\mathrm{BNH}$, que deveriam ser os órgãos centrais relativamente ao desenvolvimento urbano, principalmente na área de habitação e planos diretores. As propostas do SERFHAU serviam de modelo às prefeituras, que se incumbiam da função de promover a elaboração e implantação dos planos (Planos de Desenvolvimento Local Integrado). Segundo o Art. 55 da Lei, o Serviço Federal de Habitação e Urbanismo tinha as seguintes atribuições (destaques da autora):

a) promover pesquisas e estudos relativos ao déficit habitacional, aspectos do planejamento físico, técnico e sócio-econômico da habitação;

b) promover, coordenar e prestar assistência técnica a programas regionais e municipais de habitação de interesse social, os quais deverão necessàriamente ser acompanhados de programas educativos e de desenvolvimento e organização de comunidade;

c) fomentar o desenvolvimento da indústria de construção, através de pesquisas e assistência técnica, estimulando a iniciativa regional e local;

d) incentivar o aproveitamento de mão-de-obra e dos materiais característicos de cada região;

e) estimular a organização de fundações, cooperativas, mútuas e outras formas associativas em programas habitacionais, propiciando-lhes assistência técnica;

f) incentivar a investigação tecnológica, a formação de técnicos, em qualquer nível, relacionadas com habitação e urbanismo;

g) prestar assistência técnica aos Estados e Municípios na elaboração dos planos diretores, bem como no planejamento da desapropriação por interesse social, de áreas urbanas adequadas a construção de conjuntos habitacionais;

h) promover, em colaboração com o Instituto Brasileiro de Geografia e Estatística, a realização de estatísticas sobre a habitação no país;

i) (Vetado);

j) prestar assistência técnica aos Estados, aos Municípios e às empresas do país para constituição, organização e implantação de entidades de caráter público, de economia mista ou privadas, que terão por objetivo promover a execução de planos habitacionais ou financiá-los, inclusive assisti-los para se candidatarem aos empréstimos do Banco Nacional da Habitação ou das sociedades de crédito imobiliário;

I) prestar assistência técnica na elaboração de planos de emergência, intervindo na normalização de situações provocadas por calamidades públicas; 
m) estabelecer normas técnicas para a elaboração de Planos Diretores, de acordo com as peculiaridades das diversas regiões do país;

n) assistir aos municípios na elaboração ou adaptação de seus Planos Diretores às normas técnicas a que se refere o item anterior.

$\S 1^{\circ}$ Os municípios que não tiverem códigos de obras adaptados às normas técnicas do Serviço Federal de Habitação e Urbanismo ou que aprovarem projetos e planos habitacionais em desacordo com as mesmas normas, não poderão receber recursos provenientes de entidades governamentais, destinados a programas de habitação e urbanismo.

$\S 2^{\circ}$ (Vetado).

Art. 56. A organização administrativa do Serviço Federal de Habitação e Urbanismo será estabelecida em decreto, devendo ser prevista a sua descentralização regional. ${ }^{70}$

Destaca-se que o BNH era o órgão gestor dos recursos para o financiamento urbano, e o SERFHAU dedicava-se especificamente às questões técnicas, mas tanto em um aspecto como em outro, fica claro a subordinação dos Estados e municípios ao interesse central. Mesmo com os interesses do governo central subjacentes à sua criação, o SERFHAU pode ser considerado como o "marco do planejamento urbano", através do seu Sistema Nacional de Desenvolvimento Local Integrado que compreendia, em nível regional e municipal, os aspectos econômicos, sociais, físicos e institucionais do planejamento urbano.

Apesar de teoricamente o SERFHAU ser o órgão técnico central responsável pelas questões do desenvolvimento urbano, para Kohlsdorf (1976), "pode-se dizer que, até a criação da CNPU em 1974, o executor efetivo da Política Nacional de Desenvolvimento Urbano era o $\mathrm{BNH}$, cujos recursos provenientes do Fundo de Garantia de Tempo de Serviço aplicavam-se majoritariamente aos programas setoriais, abrangendo subsistemas urbanos outros além do habitacional, como saúde pública (saneamento), produção, comércio, equipamentos comunitários, em todos os estados da Federação." BNH e SERFHAU não se afinaram em termos de ações em torno do desenvolvimento urbano, o que reduziu esse plano (a PNDU) a mero discurso do governo federal, na opinião de Monte-Mór (2008).

Como a instituição das regiões metropolitanas, em 1974 criou-se a citada CNPU (Comissão Nacional de Regiões Metropolitanas e Política Urbana), para assumir a coordenação da política urbana nessas regiões. Essa comissão tinha como funções: "acompanhar a implantação do sistema de regiões metropolitanas e propor diretrizes, estratégias e instrumentos da Política Nacional de Desenvolvimento Urbano, bem como acompanhar e avaliar sua execução; propor as diretrizes da Política Nacional de

${ }^{70}$ FONTE: PLANALTO LEI 4.380/1964 (LEI ORDINÁRIA, 1964-08-21). 
Desenvolvimento Urbano, e articular-se com ministérios, superintendências de desenvolvimento regional, e demais órgãos governamentais envolvidos com a execução da PNDU de modo a assegurar a implementação conjunta dos programas e projetos estabelecidos" (CINTRA, 1978, p. 244).

Apesar de ser claro o papel gerencial centralizador desses órgãos, no texto da PNDU de 1975, a gestão das metrópoles constava como atribuída aos Estados, dentro da visão de gestão por "serviços comuns de interesse metropolitano". A gestão deveria ser feita por meio dos Conselhos Deliberativo e Consultivo, criados a nível estadual.

O Conselho deliberativo tinha por competência promover a elaboração do Plano de Desenvolvimento Integrado da Região Metropolitana e coordenar a execução de programas e projetos de interesse da Região Metropolitana. O Conselho Consultivo só tinha a função de "opinar e sugerir" sobre esses assuntos. Os membros dos Conselhos eram nomeados pelos governadores e ou eram do poder público ou eram técnicos, e não havia abertura para participação de representantes da sociedade em tais conselhos.

Num contexto de centralização, autoritarismo e controle central sobre as decisões intergovernamentais, fica evidente que a possibilidade de inclusão da participação social nesses processos passava bem ao largo de qualquer intenção do governo central, que tratou logo de neutralizar ou cooptar adversários ou possíveis oponentes à "marcha do progresso racionalista do desenvolvimento nacional" por meio da dissolução dos partidos, de forma a remover qualquer coalização contrária às decisões tomadas centralmente.

Pode-se concluir que as relações intergovernamentais na PNDU de 1975 eram claramente marcadas pela ingerência federal através de ideologia do planejamento racional. A autonomia municipal era limitada pelo condicionamento financeiro a certas normas e diretrizes do planejamento federal, geralmente impostas através do $\mathrm{BNH}$. A estratégia criada para garantir essa dependência passava principalmente pelo processo de obtenção de recursos para as obras, que em linhas gerais seguiam por várias instâncias e trâmites até ter sua aprovação definitiva. Serra (1991, p. 75) pontua essas possibilidades: 
1. "Ao iniciar o processo era necessário consultar uma série de funcionários dos diversos órgãos para saber se o projeto era "enquadrável" nos programas existentes;

2. era necessário saber se o Município preenchia todas as condições exigidas;

3. Verificar se o agente financeiro achava que havia capacidade de endividamento;

4. Aguardar na incerteza se os projetos apresentados seriam aprovados;

5. Aguardar a aprovação do Banco Central e ver obteria aprovação do Conselho Monetário;

6. Verificar se a Secretaria de Planejamento não criaria obstáculos;

7. Depender do Presidente da República ou Chefe da Casa Civil para dar encaminhamento;

8. Aguardar se os senadores dariam andamento ao processo etc".

Essas eram as "regras do jogo" para aprovação de projetos, que na verdade baseavam-se na falta de clareza, e que ainda contavam com a incerteza de "interesses políticos" que pudessem se opor à liberação de tal recurso para cidade do prefeito do partido adversários..." Enfim, a autonomia municipal também era suprimida por questões político-partidárias, segundo Serra, que destaca a ocorrência de "transferência em massa de prefeitos para o partido do governo, com o objetivo de não prejudicarem suas cidades que, de outra forma, estariam excluídas das benesses federais" durante o período militar (op. cit. 1991, p. 147).

Segundo Serra, "o que a ideologia da decisão esconde é o fato de que a cidade é o espaço da confrontação de interesses variados e múltiplos. De outro lado, o tecnocrata se considera o dono de uma saber específico que o habilita a tomar decisões com base na mais absoluta racionalidade", o que se reflete na "atitude do centralismo autoritário procurando eliminar a autonomia das autoridades locais, para que as mesmas tivessem que se enquadrar nas diretrizes de planejamento federal, assim como se viu a pretensão de se tomar o processo despolitizado e racional" (Idem, p. 74).

\subsubsection{A estrutura institucional da PNDU de 2004: a tentativa de pactuação federativa democrática}

O modelo de política urbana desenvolvido no período não resistiu à crise econômica que se abateu sobre o país nas décadas de 80 e 90, levando à falência do BNH e à desarticulação dos órgãos e instituições direcionadas ao desenvolvimento urbano. "Com a Caixa Econômica assumindo o espólio do $\mathrm{BNH}$, tem início uma verdadeira via crucis institucional da política urbana, reveladora da pouca importância 
que ela tem na agenda nacional a partir da crise econômica" (MINISTÉRIO DAS CIDADES, 2004a, p. 10).

O tratamento da questão urbana passou por pastas ministeriais as mais diversas, desde "Bem-estar", a "Ação Social" à associação com meio-ambiente e descolamento dos transportes da questão urbana. A CEF, sem um direcionamento claro, como detentora e administradora dos recursos do FGTS - maior fonte de recursos da habitação e do saneamento - acabou por se tornar cada vez mais responsável pelos rumos do desenvolvimento urbano.

Conforme se pode ver no Quadro 6, as políticas urbanas passaram por atribuições de diversas pastas do governo, até a criação de um Ministério específico para o desenvolvimento urbano, que foi o Ministério das Cidades, em 2003.

Quadro 6- Sucessão de Ministérios relacionados ao Desenvolvimento Urbano - de 1964 a 2003

\begin{tabular}{|c|c|}
\hline \multicolumn{2}{|r|}{ SUCESSĀO DE MINISTÉRIOS RELACIONADOS AO DESENVOLVIMENTO URBANO } \\
\hline ANO & EVENTO \\
\hline 1964 a 1985 & $\begin{array}{l}\text { Serviço Federal de Habitação e Urbanismo, depois sucedido pela } \\
\text { Comissão Nacional de Política Urbana e Regiões Metropolitanas / Banco } \\
\text { Nacional da Habitação (BNH) eSistema Financeiro da Habitaç ão (SFH) / Plano } \\
\text { Nacional de Saneamento (Planasa) e Sistema Financeiro do Saneamento. } \\
\text { Criaç ão do FGTS }\end{array}$ \\
\hline 1985 & $\begin{array}{l}\text { Extinção do BNH. Fragmentos do Planasa e do SFH sobrevivem no espólio } \\
\text { herdado pela Caixa Econômica Federal }\end{array}$ \\
\hline 1986 a 2002 & $\begin{array}{l}\text { Rumo errático do desenvolvimento urbano, habitação, saneamento e } \\
\text { transporte urbano }\end{array}$ \\
\hline 1985 & Ministério do Desenvolvimento Urbano e Meio Ambiente \\
\hline 1987 & Ministério da Habitação, Urbanismo e Meio Ambiente \\
\hline 1988 & Ministério do Bem Estar Social \\
\hline 1990 & Ministério da Ação Social \\
\hline 1995 & Secretaria de Política Urbana / Min. Planejamento e Orçamento \\
\hline 1999 & Secretaria Especial de Desenv. Urbano / Presidência da República \\
\hline 2003 & Criação do Ministério das Cidades. \\
\hline
\end{tabular}

Fonte:MARICATO (2006)

O Ministério desde a sua criação está estruturado da seguinte forma: uma Secretaria Executiva; as Secretarias Nacional, de Habitação, Ambiental, Transporte e Programas Urbanos, além do Conselho das Cidades e órgãos de trânsito e transporte. Conta ainda com a herança institucional dos períodos anteriores, principalmente programas e recursos da Caixa Econômica Federal e do BNDES.

$\mathrm{Na}$ estruturação do Ministério, a CEF ainda possui papel relevante, principalmente na liberação de recursos para o financiamento de empreendimentos urbanos, nos mais diversos níveis de renda. Embora as companhias de habitação 
estaduais e municipais tenham um papel importante nessas parcerias com a CEF, o setor habitacional ainda é fortemente marcado pela presença do governo federal.

A busca de intersetorialidade das políticas urbanas também tem sido um tema constante do discurso da PNDU, mas prevalece ainda o recorte do desenvolvimento urbano marcado por setores, da habitação, do saneamento, dos transportes (mobilidade) e trânsito na gestão dos problemas urbanos, estando cada "pasta" voltada para as políticas, programas, planos e ações dentro de sua área específica.

Criado o Ministério, ficou como o principal responsável pela elaboração e implementação da Política Nacional de Desenvolvimento Urbano, buscando, porém em contraste com a PNDU de 1975, desenvolver um trabalho conjunto com os demais níveis de governo, não somente centralizado, e ainda com a participação social, dentro da premissa da "pactuação federativa democrática", que tem sido a premissa básica das decisões e ações previstas e implementadas a partir dessa instância.

\section{II}

Como já visto no Capítulo 2, as diretrizes iniciais da PNDU têm sido levado à prática via planos, programas e ações das propostas estruturantes dentro de cada área, buscando apoiar as Estados e municípios no que seja de suas competências, com intuito de fortalecer o já fragilizado pacto federativo.

A estrutura descentralizada do governo e o município como ente federado são condições que diferem em termos institucionais do contexto da PNDU anterior. Em tese, na condição de federações com administração descentralizada, o aumento da "distância" do centro de decisões da política urbana nacional, por exemplo, para os centros de decisão da implementação, que estão em Estados e municípios podem dificultar os trâmites e aprovações de mudança necessária, principalmente em caso que haja discordância de alguma linha de ação ou pressupostos.

Mas Arretche (2002) acredita que o caso brasileiro se mostre menos propenso a que reformas propostas pelo governo federal sejam majoritariamente vetadas pelos governos locais: "Em outras palavras, diferentemente das previsões da literatura que enfatiza o poder de veto dos governos subnacionais no federalismo brasileiro, estes últimos não representaram um ponto de veto intransponível à implementação da agenda de reformas do governo federal nessas políticas particulares". Isso se mostrou 
particularmente evidente nas políticas sociais analisadas pela autora de saúde, habitação e saneamento, cujas reformas propostas pelo governo federal encontraram poucas resistências nos governos subnacionais nos casos analisados.

Isso parece fato quando se faz a verificação dos resultados iniciais obtidos no contexto da PNDU, na análise de Maricato e Santos Jr. Nos primeiros dois anos os esforços foram dirigidos para a institucionalização e funcionamento do Ministério, a retomada dos investimentos públicos (que foram bem sucedidos em habitação e saneamento ambiental, dadas as ações prioritárias para reorganização dessas áreas), a estruturação das Secretarias Nacionais com suas políticas setoriais, a readequação dos organismos que foram herdados pelo Ministério (Denatran, CBTU e Transurb) e especialmente a realização da Conferencia Nacional das Cidades e a implantação do Conselho das Cidades, o que ocorreu no primeiro semestre de 2004 (Maricato e Santos Jr, 2006).

No balanço para a realização da $3^{\underline{a}}$ Conferência das Cidades (que ocorreu em 2007) apresentaram-se passos importantes que já foram dados para a consecução da Política Nacional de Desenvolvimento Urbano:

"a promulgação da Constituição Federal de 1988, em especial os artigos
6o.., 182 e 183; a aprovação do Estatuto das Cidades - Lei no. $10.257 / 01$;
a edição da Medida Provisória $2220 / 01$; a criação do Ministério das
Cidades; a criação do Conselho das Cidades e do processo de
Conferências das Cidades; a criação do Sistema e Fundo Nacional de
Habitação de Interesse Social - Lei no $11.124 / 05 ;$ a aprovação do marco
regulatório da Política Nacional de Saneamento Básico - Lei no
11.445/07; a aprovação da Lei de Consórcios Públicos - Lei no
11.107/05; a proposição do Projeto de Lei da Mobilidade Urbana - PL no
1687/07; a aprovação da lei voltada à regularização fundiária em áreas
da União - Lei no 11.481/07; a retomada e ampliação de recursos para
habitação e saneamento, apesar de ainda insuficientes, e início de um
processo de revisão de prioridades de investimento dos recursos públicos
federais para população de baixa renda; a flexibilização de limites de
endividamento para o setor público; e a realização da Campanha
Nacional para Elaboração de Planos Diretores Participativos."
(MINISTÉRIO DAS CIDADES, 2010)

O mesmo documento, produzido a partir dos debates do Conselho das Cidades, aponta ainda uma contradição evidente entre a constante afirmação de necessidade de "intersetorialidade" e a manutenção de uma estruturação marcadamente setorial da PNDU, como já enfatizado, que tem se refletido nas suas diretrizes e implementações 
já possíveis de serem vistas, como "uma somatória" das políticas setoriais de habitação, saneamento, mobilidade, entre outras.

O relatório citado também indica caminhos para avanços no debate seguinte, apontando para a necessidade de: participação efetiva do planejamento territorial integrado; da legitimação do controle social por meio dos Sistema de Conselhos e Conferências e acompanhamento de ações em andamento; de uma estrutura institucional federativa adequada às diretrizes da PNDU, com devidos respaldos financeiro, partindo das três esferas nas partes que lhe cabem; e fundos e mecanismos financeiros que garantam a factibilidade dos programas e ações para o desenvolvimento urbano definidas na PNDU.

\title{
III
}

Como destaque da estrutura institucional da PNDU, a abertura à participação social, tanto para formulação, quanto monitoramento e avaliação das proposições e ações da política urbana nacional é inovadora e vai de encontro à tradição política nacional, de escamoteação de conflitos, de tratamento da esfera pública como esfera privada pelo Estado, de controle dos aparelhos estatais. Como afirmam Maricato e Santos Jr.:

\begin{abstract}
"não se trata de ignorar, ingenuamente, o papel da luta de classes, que ganha contornos dramáticos, no capitalismo global. Nem se desconhece a sobrevivência da tradicional e cultural manipulação do aparelho do Estado como coisa privada e pessoal no Brasil. Mas trata-se de dar visibilidade aos conflitos, sempre ocultados pela tradição do 'homem cordial' e construir novos paradigmas de consciência e organização social que contrariem o patrimonialismo na condução do Estado" (MARICATO E SANTOS Jr, 2007).
\end{abstract}

Com a abertura política no final da década de 80 , os movimentos e debates pela Reforma Urbana que voltaram à cena, tiveram "por inúmeras vezes "formulada a proposta de criação de uma instância federal voltada para as políticas urbanas no decorrer dessa luta social. No entanto, foi no Projeto Moradia, divulgado em 2000, que o Ministério das Cidades foi formulado mais claramente, ocupando um vazio institucional que retirava completamente o governo federal da discussão sobre a política urbana e o destino das cidades (MARICATO, 2006).

Foi a partir dessa base "reformista" intelectual e militante dos movimentos sociais que a proposição do Ministério das Cidades teve êxito. A sua criação e estruturação, está portanto "ligada a esse movimento social urbano que teve início 
ainda nos anos 1970 e que acumulou forças nas duas décadas seguintes na luta pela democratização do país e pela reforma urbana" (MARICATO, 2006, p. 214). A engenharia institucional de apoio à PNDU de 2004 se deve em grande parte à abertura dada aos movimentos sociais para participação nos "processos decisórios".

A incorporação de um órgão colegiado de deliberação com composição dos diversos segmentos da sociedade, como é o Conselho das Cidades, é algo a ser destacado como "contra-mão" da lógica patrimonialista do Estado, e ainda por ser esse órgão responsável pela condução do processo de elaboração da política nacional de desenvolvimento urbano, que se constrói e se renova também "democraticamente" a partir dos debates públicos nas Conferências das Cidades.

Juntamente com os movimentos de Reforma Urbana, tomam lugar a partir de meados da década de 1970, as prefeituras progressistas democráticas, com perfis inovadores de gestão mais participativa nas decisões do espaço urbano.

"Paralelamente ao retorno dos movimentos sociais à cena política, ainda sob contexto da ditadura, têm início as experiências democráticas de administração municipal (excluindo as capitais cujos prefeitos eram indicados por governadores que, por sua vez, eram indicados pelas autoridades da Ditadura) com a eleição de prefeitos progressistas. Começa um novo período no qual se colocavam em prática propostas elaboradas nas mobilizações e organizações populares. Arquitetos, engenheiros, advogados, assistentes sociais, geógrafos dedicaram-se a formular, por meio de processos democráticos, novos programas e novas formas de gerir as cidades" (MARICATO, 2010, p. 18).

Destacaram-se nesse período as administrações de São Paulo e Porto Alegre, que teve no primeiro Ministro das Cidades, Olívio Dutra, figura política que se sobressaiu no processo de redemocratização gaúcha, cujo modelo de inclusão política social serviu de referência para administrações públicas em diversos outros municípios.

Acredita-se que a força do movimento de redemocratização, a eleição de um partido de esquerda e a experiência político-democrática do ministro e seus assessores diretos (acadêmicos, técnicos, pessoas engajadas no MRU), foram fatores que combinados permitiram a abertura da estrutura ministerial à participação da sociedade no processo de elaboração da política nacional de desenvolvimento urbano. Para Maricato e Santos Jr. "a saída do Olívio Dutra do Ministério das Cidades interrompeu a 
continuidade da estratégia traçada para a PNDU - Política Nacional de Desenvolvimento Urbano".

Essa troca ministerial entra justamente no rol das alianças político-partidárias necessárias para a formação das bancadas de apoio ao governo, movimentos típicos do presidencialismo de coalizão. O jogo de interesses, os pequenos círculos de poder (as burocracias), o clientelismo e o patrimonialismo são ainda práticas que rondam a esfera governamental e que podem impedir maiores avanços na construção mais justa e democrática do desenvolvimento urbano e na cooperação federativa e intergovernamental.

\subsubsection{Considerações sobre as relações intergovernamentais no Brasil}

Apesar de em alguns casos não representarem "barreiras intransponíveis" para aprovação de reformas, não se pode negar a existência dos "pequenos" centros de poder regionais concentrados no país.

A capacidade de influência dessas oligarquias ou burocracias regionais, além das questões institucionais, foi e ainda continua sendo diretamente proporcional à riqueza da região - ou potencial de riquezas. Tome-se como exemplo o caso da região Sudeste, a mais rica do país, que notadamente recebeu privilégios de investimentos, principalmente no momento de montagem da base industrial nacional, formando num primeiro momento as economias de aglomeração e pode-se dizer que ainda hoje.

Historicamente a associação entre o capital e o poder político certamente garantiram a tomada de decisões que privilegiaram os investimentos em determinadas zonas de influência eleitoral. As relações entre o governo federal e as burocracias locais, geralmente marcada pelo clientelismo e pelos "Iobbies", permitiram que planos, programas e projetos fossem implementados nessas cidades com os recursos do governo federal ${ }^{71}$.

Por outro lado, em muitos momentos o governo federal usou de seus recursos governativos para suplantar interesses dos governos locais. Isso ficou muito claro no

\footnotetext{
${ }^{71}$ Fica claro o movimento de indução do desenvolvimento de uma dada região pelo poder central, mas de forma desequilibrada.
} 
período do regime militar, concentrando na sua esfera e nos seus agentes a formulação e a execução de políticas urbanas, como bem expressa Arretche (2002):

\begin{abstract}
"Quer para a política de habitação social quer para o saneamento básico, o modelo do regime militar era simultaneamente estatal e centralizado. A oferta de bens e serviços fazia-se via produção pública - a habitação social e os serviços de saneamento básico eram geridos por empresas estatais. No plano federal, havia uma agência que centralizava a formulação das políticas e a arrecadação da principal fonte de financiamento da política, o Fundo de Garantia por Tempo de Serviço FGTS. Com base nesse modelo, constituiu-se no país uma rede de 44 empresas públicas municipais e estaduais de habitação social, assim como 27 companhias estaduais de saneamento" (Idem, 2002, p. 435)
\end{abstract}

A relação intergovernamental era, portanto, baseada não na cooperação e "divisão" de competências, mas na tomada de decisões centralizada como já visto, fazendo valer a sua execução via disseminação de agências governamentais espalhados pelos estados. Essa foi a tônica que seguiu durante todo o período do regime militar, reforçada pela Constituição Federal de 1967: "Art 8 - § 1ำ A União poderá celebrar convênios com os Estados para a execução, por funcionários estaduais, de suas leis, serviços ou decisões. Mas também deveriam observar que: Art. 9o - A União, aos Estados, ao Distrito Federal e aos Municípios é vedado: I - criar distinções entre brasileiros ou preferências em favor de uns contra outros Estados ou Municípios" (BRAISL, 1967).

Isso implica que claramente na prática as determinações constitucionais pouco influenciavam nas relações intergovernamentais, sujeitando-se a gestão das políticas públicas ao curso mandatório do modelo de gestão imposto pela tecnocracia que estava no poder. Nos contextos governativos mais recentes, esse modelo, porém, foi duramente criticado pela sua ineficiência, uma vez que marcado pelo "peso estatal", não dava abertura a que os "processos mais eficientes de gestão" tomassem seu lugar. Segundo Arretche:

"O Executivo federal avaliava - na transição democrática - que a corrupção e ineficiência administrativas das gestões civis precedentes foram possíveis graças à centralização federal; por conseguinte, era forte a concepção, derivada desta primeira, que associava positivamente descentralização a formas mais ágeis, democráticas e eficientes de gestão. A defesa da descentralização era ainda reforçada pela avaliação de que a burocracia federal estava viciada nos padrões administrativos prévios. Além disso, o Executivo federal considerava que o modelo anterior gerava incentivo à ineficiência das prestadoras estaduais e municipais. Políticas tarifárias voltadas a satisfazer o eleitorado, 
renegociação sistemática das dívidas com o governo federal, empreguismo e uma burocracia ativa na defesa de seus próprios interesses eram o resultado do modelo anterior. A separação entre regulação (estatal) e provisão (privada ou pública com padrões privados de eficiência) seria a alternativa mais adequada (ARRETCHE, 2002, p. 435).

Assim, procurou-se estabelecer um "novo padrão" gerencial de gestão pública que é o que tem permeado a governança não só no nível federal, mas também nos níveis estadual e local, fortemente embasada no ideário de eficiência pública do neoliberalismo, com redução de gastos públicos e parcerias privadas para atração do capital e de financiamentos externos, resultando no empresariamento das cidades, que devem se manter atrativas no "mercado" internacionais, seja para investimentos empresariais, turísticos de lazer etc. animado de certa forma as parcerias intergovernamentais em determinados momentos.

Entra assim a idéia de "mínimo denominador comum" no acordo entre os governos, seja por reformas ou políticas mais "polêmicas", em que o interesses nem sempre se alinham, mas podem ser ajustados, incorporados, negociados etc., ou no caso em que de haja interesses comum, estabelecidas as parcerias e convênios nas relações verticais e horizontais. No caso brasileiro, Arretche (2002, p. 451) reforça que "em razão da sua autonomia política e fiscal, os governos subnacionais adotam as políticas federais apenas por adesão voluntária ou obrigação constitucional" e que as relações intergovernamentais, por sua vez, "são condicionadas por regras constitucionais, legado de políticas anteriores e o ciclo da política”.

A superação desse quadro só foi possível na PNDU de 1975, e tem sido de alguma forma, tema constante de debate na elaboração da PNDU de 2004, com a proposição de parcerias, consórcios, convênios, ainda em nível incipiente de experimentação. $^{72}$

Há que se lembrar que para a execução dos "serviços de interesse comum" ou se efetivar um programa "intergovernamental", não se trata apenas de uma questão de alinhamento de interesses, ou de gestão. A tensão das relações horizontais e verticais se torna mais problemática ainda no tocante aos mecanismos financeiros de suporte ao desenvolvimento dessas atividades. Para Almeida (2005) o federalismo fiscal "constitui a espinha dorsal das relações intergovernamentais e por isso deve ser levado em conta

\footnotetext{
${ }^{72}$ Sobre a Lei dos Consórcios, o tema será melhor abordado no item sobre Instrumentos Legais.
} 
entre os fatores interferentes nas políticas de desenvolvimento urbano e seus instrumentos ou meios de implementação.

\subsection{INSTRUMENTOS FINANCEIROS}

\subsubsection{O federalismo fiscal}

O federalismo fiscal trata da distribuição das finanças (receitas, tributos e transferências) entre os entes federativos, da forma como os recursos fiscais e parafiscais são gerados e distribuídos entre os diferentes níveis, os quais definem, em boa medida, as feições da federação.

Sobre isso, Lemgruber (2009) esclarece que "o mecanismo de transferências intergovernamentais tem por objetivo básico corrigir os problemas de desequilíbrios verticais e horizontais existentes em qualquer federação". Segundo Pinto (2007), "desequilíbrios verticais referem-se a descompassos entre a capacidade de tributar e as responsabilidades de gastos entre os diversos níveis governamentais" (União, estados e municípios), enquanto os desequilíbrios horizontais são relativos a governos situados no mesmo nível de hierarquia, no caso brasileiro, os estados e municípios.

Pinto (2007) defende que o desequilíbrio vertical ocorre devido ao fato de que alguns tributos são melhor administrados em nível central e algumas despesas em nível local e que a política de gastos tende a ser melhor desenhada e controlada pelos governos locais, uma vez que estão mais próximos dos cidadãos e de suas necessidades básicas. Já os desequilíbrios horizontais refletem as diferenças interregionais de renda, apontando-se que regiões mais ricas e com uma base econômica mais desenvolvida deverão ter maior arrecadação que as regiões com menor potencial econômico.

Para Silva (1995) a ação governamental orientada a políticas redistributivas processa-se primordialmente por intermédio da política fiscal, ainda que políticas monetárias e cambiais também exerçam impactos sobre as rendas individuais e regionais. Em síntese, a política fiscal redistributiva pode ser implementada pela operacionalização de três instrumentos, a saber: (i) a progressividade do sistema tributário: (ii) o direcionamento das transferências fiscais intergovernamentais; (iii) o perfil da cesta de bens provisionados pelo governo. 
A "motivação redistribuição" estaria vinculada a objetivos orientados à redução das diferenças fiscais entre unidades federativas, derivadas dos diferenciais relacionados ao grau de desenvolvimento da atividade econômica, à dimensão da base tributária, aos custos de produção e ao perfil da demanda por bens cuja provisão, sendo de responsabilidade do setor governo. Os ajustes na estruturação do federalismo fiscal nacional buscam uma compensação nesses desequilíbrios internos, mas tem gerado muito mais conflitos do que entendimentos, o que leva a uma desconfiança sobre as possibilidades de acordos cooperativos, consórcios, alianças ou quaisquer outras formas de integração regional ou federativa para o desenvolvimento de políticas de interesse comum.

A definição clara e precisa de competências que devem ser atribuídas a cada nível de governo e os respectivos arcabouços institucionais que apóiem o desenvolvimento dessas competências são dois elementos essenciais dentro do pacto federativo nacional. Isso porque, como se observa em Silva (2005, p. 119), "a adoção do federalismo fiscal implica em distribuição de competências constitucionais fiscais entre os diferentes níveis de governo, para que cada um, de modo autônomo, e na medida de suas competências e capacidade de financiamento, possa construir desenhos institucionais capazes de disciplinar os procedimentos de contribuição e gestão tributária, transferências fiscais, composição e dimensão da despesa".

\subsubsection{A PNDU de 1975: financiamento e ajustes fiscais}

Já se viu em debates anteriores que algumas situações em específicos marcaram o financiamento dos programas e ações da PNDU de 1975: a Reforma Tributária de 1967, a centralização da liberação de recursos aos Estados e municípios por parte do Governo Federal, o privilégio de investimentos em alguns setores e algumas regiões.

I

A reforma tributária de 1967, produto de decisões tecnocráticas e centralizadoras, é considerada uma "manobra" de centralização de recursos, de forma a reduzir cada vez mais a autonomia de Estados e municípios. Pelo novo arranjo fiscal, no período de 1968 a 1972, a arrecadação municipal caiu de $12 \%$ para 10\%, a Estadual, de $42 \%$ para $40 \%$ e a Federal subiu de 46 para 50\% (Serra, 1991, p. 53). 
Tabela 3 - Receita total arrecadada por esfera de governo no contexto da PNDU de 1975

\begin{tabular}{|c|c|c|c|}
\hline \multicolumn{3}{|c|}{ RECEITA TOTAL ARRECADADA, POR ESFERA DE GOVERNO - 1968 - 1972 (EM \%) } \\
\hline ANOS & MUNICIPAL & ESTADUAL & FEDERAL \\
\hline 1968 & $12 \%$ & $42 \%$ & $46 \%$ \\
\hline 1969 & $11 \%$ & $38 \%$ & $51 \%$ \\
\hline 1970 & $11 \%$ & $36 \%$ & $55 \%$ \\
\hline 1971 & $11 \%$ & $42 \%$ & $47 \%$ \\
\hline 1972 & $10 \%$ & $40 \%$ & $50 \%$ \\
\hline
\end{tabular}

Fonte: FERRAZ, 1976 (citado por SERRA, 1991)

Gráfico 10 - Perfil de arrecadação das três esferas de governo de 1968 a 1972

Receita total arrecadada por efera de governo, em \%

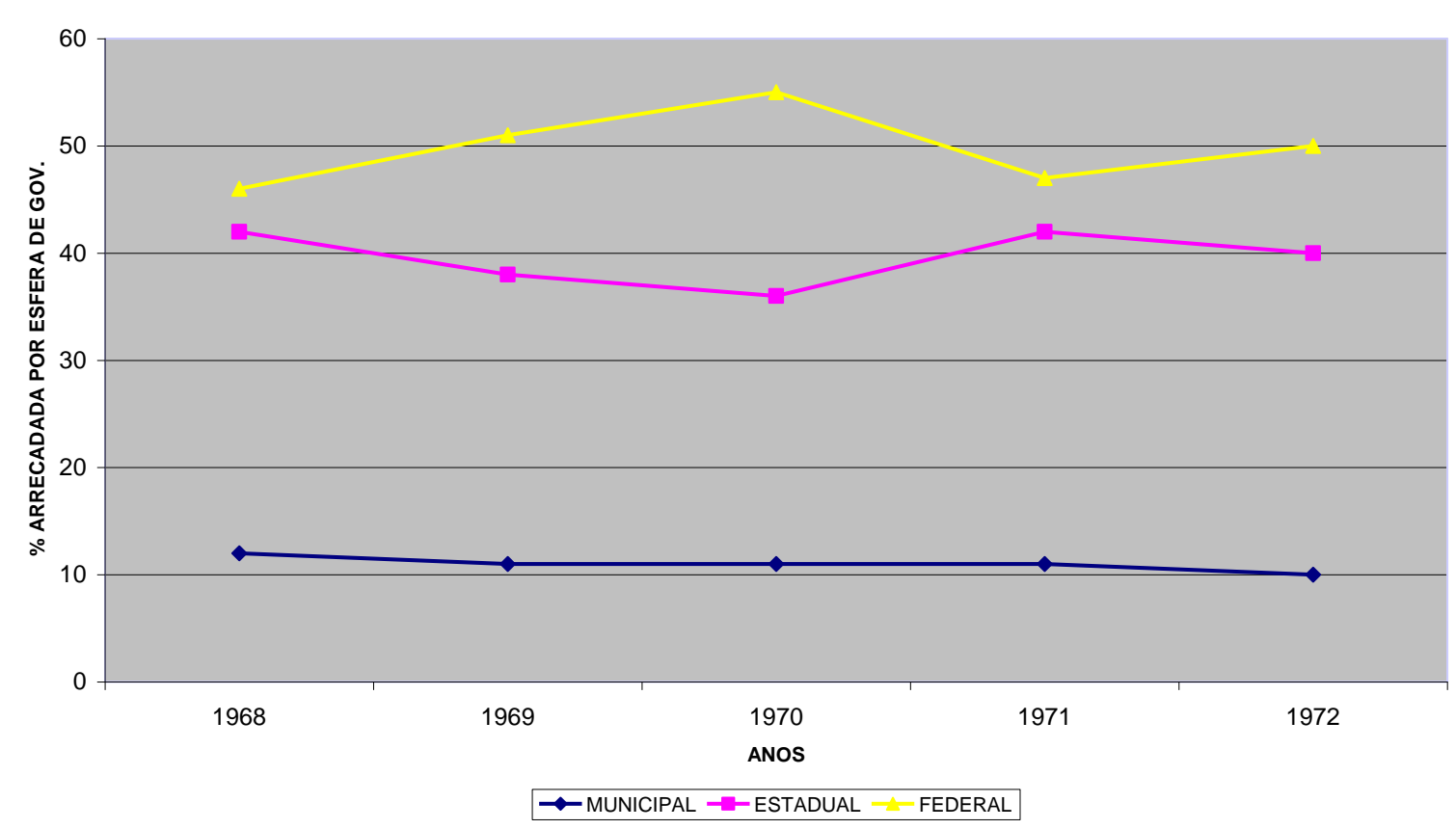

Fonte: FERRAZ (1976) (sistematização da autora).

A visão predominante dos idealizadores da Reforma Tributária era de que a autonomia dos Estados e municípios era um obstáculo a um planejamento "correto", ou seja, de acordo com os interesses do governo central "quando essas unidades têm um substancial peso e recursos próprios, e capacidade autônoma de levantar recursos próprios por tributação e empréstimo, é extremamente difícil submetê-las à disciplina do planejamento central" (Simonsem e Campos, citados por SERRA,1991,p. 54) 


\section{II}

No contexto que antecedeu a criação da PNU, em 1965, o então Ministério de Planejamento e Coordenação regional criou o Setor de Planejamento Regional e Municipal que "estimulava" a elaboração de Planos de Desenvolvimento Local Integrado (PDLI) para obtenção de recursos junto ao FINEP (Fundo de Financiamento de Estudos e Programas), recém criado, que depois virou empresa pública desvinculada desse Ministério, que passou a ser denominado de Ministério do Interior.

Depois disso foi instituído o FGTS (Fundo de Garantia por Tempo de Serviço) (em 1966), que além de servir de garantia à estabilidade trabalhista dos empregados, foi uma forma de ampliar os recursos para o financiamento de programas de habitação popular, saneamento básico e infra-estrutura urbana.

Para controlar a concessão de recursos pelo Banco Nacional de Habitação (BNH), uma vez que esses passaram a ser vultosos, a liberação aos municípios ficou atrelada à elaboração dos Planos Locais (PDLI). Essa responsabilidade passou a ser também do SERFHAU (Serviço Federal de Habitação e Urbanismo), que com a criação do FIPLAN (Fundo de Financiamento de Planos de Desenvolvimento Local), passou a regular a provisão de recursos necessários à elaboração de planos, programas e projetos de desenvolvimento urbano e local.

O Art 6ำ da Lei Complementar ำ 14/73 abria uma concessão especial para os municípios da região metropolitana que participassem da execução do planejamento integrado e dos serviços comuns, concedendo-lhes preferência na obtenção de recursos federais e estaduais, inclusive sob a forma de financiamentos, bem como de garantias de empréstimos (MINISTÉRIO DO INTERIOR, 1975, p. 44)

Os investimentos nacionais eram distribuídos setorial e regionalmente. Do total de gastos previstos, um grande volume estava destinado aos planos e programas urbanos nas áreas de habitação e saneamento para o período de 1975 a 1979, conforme se pode ver na Tabela 4.

Observa-se que os investimentos federais eram discricionariamente determinados, e não ocorreram de forma equânime em todo o território nacional, mas privilegiaram as regiões de maior concentração de indústrias, especialmente Sudeste, 
fomentando o já grande desequilíbrio inter-regional, e atraso no desenvolvimento de regiões de baixíssima concentração de capital, como Norte e Nordeste (MINISTÉRIO DO INTERIOR, 1975).

Segundo um balanço dos planos, programas e projetos implantados a partir das diretrizes da PNDU de 1975 ou em consonância com seus pressupostos e objetivos, verifica-se a assimetria de investimentos pelos setores e regiões.

Tabela 4 - Aplicações previstas para desenvolvimento urbano (1975-1979)

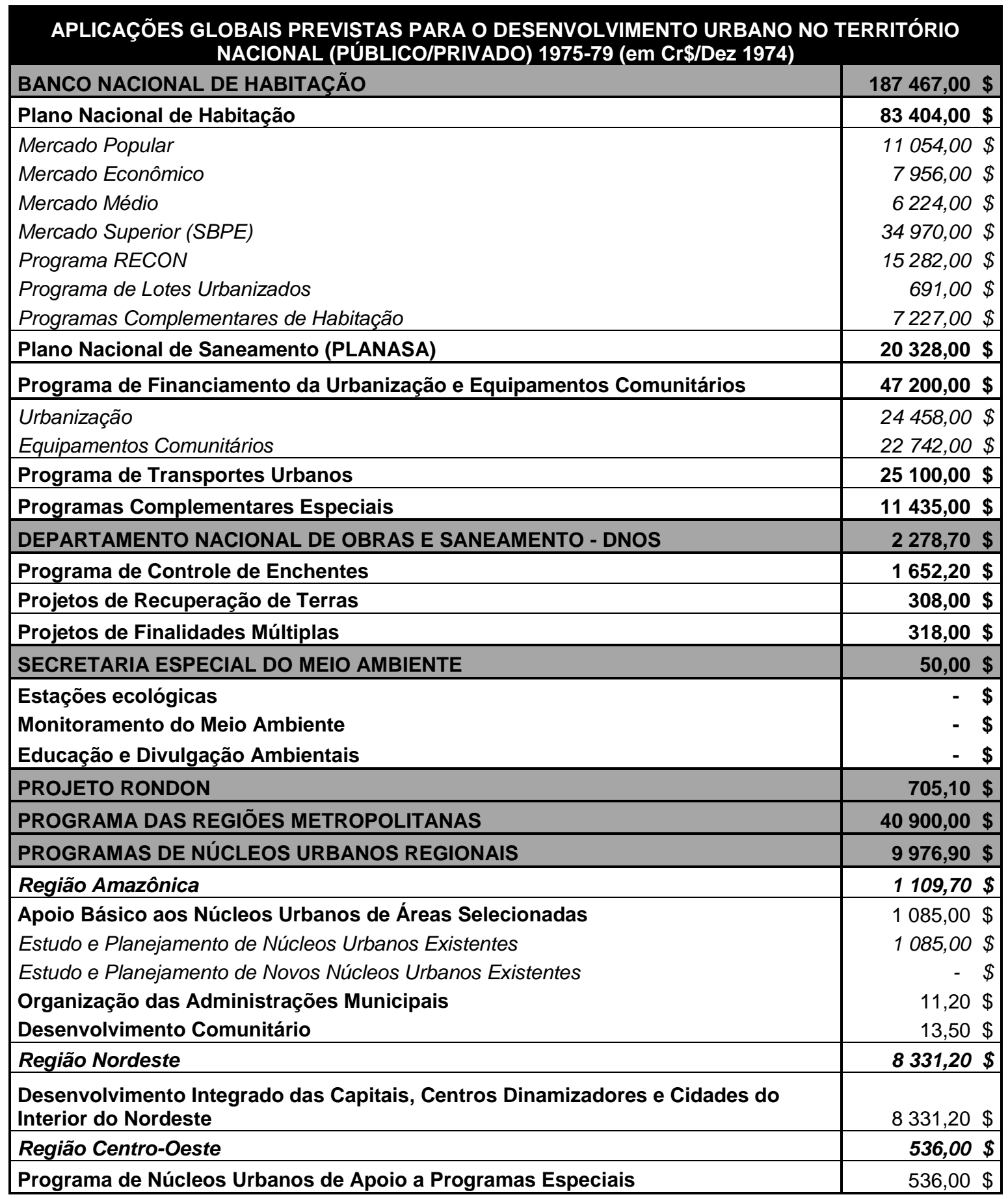




\begin{tabular}{|c|c|}
\hline OUTROS PROGRAMAS URBANOS & $129,80 \$$ \\
\hline Programa de Capacitação de Recursos Humanos & $42,50 \$$ \\
\hline $\begin{array}{l}\text { Recursos Humanos para o Desenvolvimento Urbano } \\
\text { Recursos Humanos para Administração Municipal }\end{array}$ & $\begin{array}{l}27,50 \$ \\
15,00 \$\end{array}$ \\
\hline Sistemas Estaduais de Desenvolvimento Urbano-Local & $50,00 \$$ \\
\hline $\begin{array}{l}\text { Programa de Migrações Internas } \\
\text { Pesquisa de Migracões Internas }\end{array}$ & $\begin{array}{ll}37,30 & \$ \\
14,30 \$\end{array}$ \\
\hline Centros de Triagem e Treinamento de Migrantes (CETREMIs) & $23,00 \$$ \\
\hline TOTAL & $241507,50 \$$ \\
\hline
\end{tabular}

Fonte: Ministério do Interior, 1975.

Gráfico 11- Aplicações previstas para o desenvolvimento urbano (1975-1979)

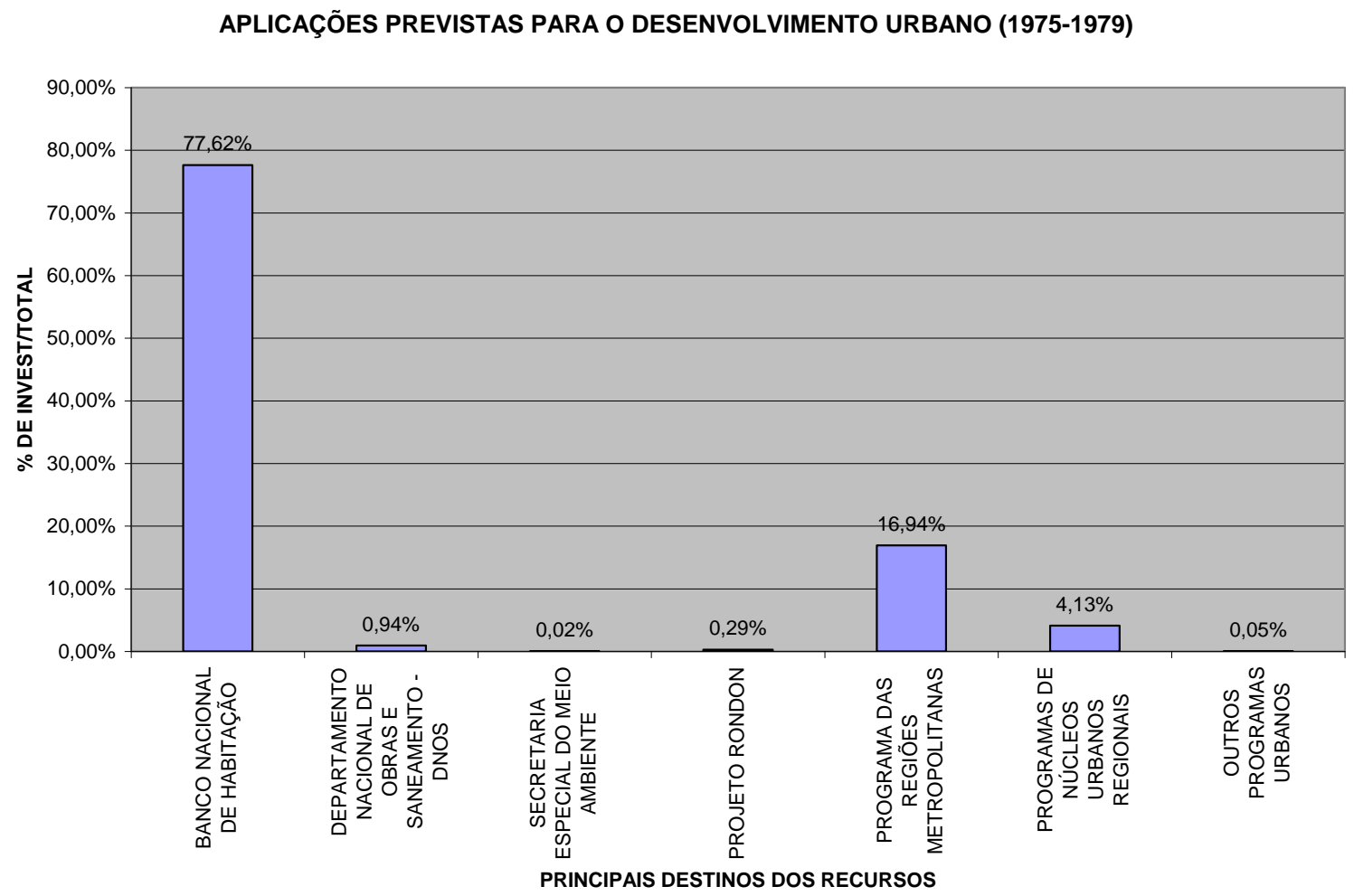

Fonte: Ministério do Interior, 1975 (Gráfico elaborado pela autora)

Colocando em destaque os investimentos por "setor", pode-se ver que o grande volume de investimentos estava concentrado no BNH (Gráfico 9), para financiamento implementação de programas de habitação (popular, mas também para classe média), saneamento e "urbanização". O segundo maior volume de recursos seria destinado às metrópoles, já que eram consideradas as principais bases do projeto de industrialização e "modernização" nacionais. 


\subsubsection{A PNDU de 2004: novas fontes de recursos e rearranjos fiscais}

\section{I}

Já no quadro da nova PNDU, com o fortalecimento da descentralização e com os municípios agora como entes federados, o arranjo fiscal assume uma importância ímpar nas relações intergovernamentais.

O atual arranjo distributivo e arrecadatório nacional tem suas origens ainda na Constituição de 1967, quando pela primeira vez se trabalhou uma reforma tributária no país. A fixação constitucional de quotas de repasse da União para os estados, e destes aos municípios (que ainda não contavam com autonomia fiscal) foi um marco no período, ampliando as possibilidades de investimentos nos níveis subnacionais, iniciando-se então um processo de descentralização de recursos sem precedentes.

Esses mecanismos de transferência se tornaram tão essenciais ao desenvolvimento dos governos que mesmo na Constituição seguinte, a de 1988, com toda a crítica ao autoritarismo e quase tudo que se relacionasse ao período da ditadura militar, o esquema distributivo não só foi mantido, como ampliadas quotas, inclusas novas transferências, e ampliadas as autonomias dos governos subnacionais.

Para MacDowel (2007), o aumento da autonomia fiscal dos municípios com a Constituição de 1988 foi marcante. Pelo lado da receita, os municípios passaram a poder fixar as alíquotas e administrar os tributos que thes foram atribuídos como também estabelecer a cobrança de taxas pela prestação de serviços. A autora esclarece como se deu essa partilha (a Figura 4 esquematiza de forma simplificada como se deu essa partilha fiscal entre os entes federados): 


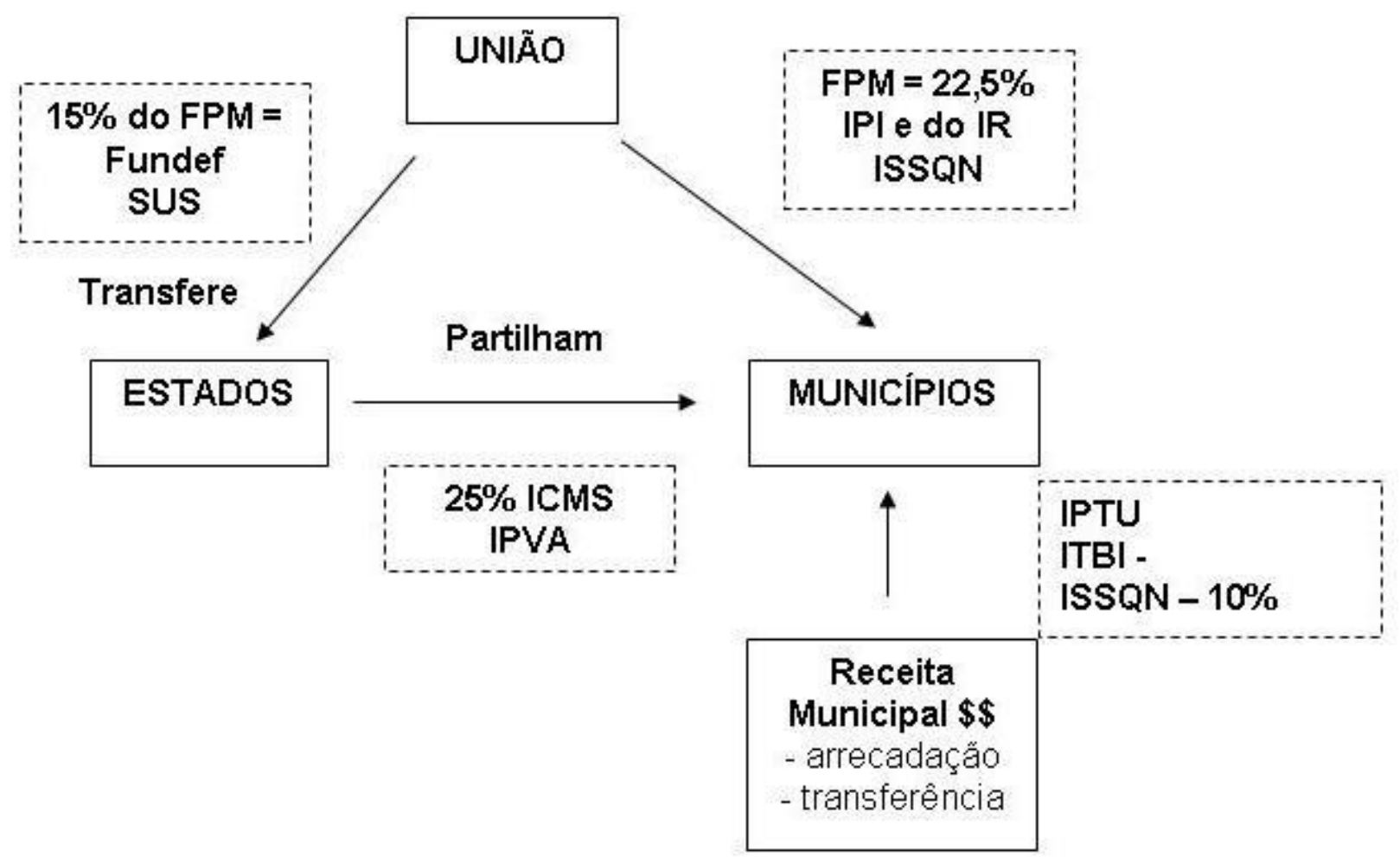

Figura 2 - Sistematização de distribuição de recursos entre os entes federados após a Constituição de 1988 (sistematização da autora).

"Foi transferida aos municípios a responsabilidade pela arrecadação do Imposto sobre Transmissão de Bens Intervivos (ITBI) e foi ampliada a base geradora do Imposto sobre Serviços de Qualquer Natureza (ISSQN). Ao mesmo tempo, houve um aumento das transferências de recursos dos governos federal e estadual para os municípios. O Fundo de Participação dos Municípios (FPM) passou a ser constituído por $22,5 \%$ da arrecadação federal do Imposto sobre Produtos Industrializados (IPI) e do Imposto sobre a Renda (IR), representando um aumento de 6,5 pontos percentuais da participação dos municípios nessas receitas com relação ao período anterior à última Carta Magna. A cota-parte dos municípios na arrecadação do Imposto sobre Circulação de Mercadorias (ICMS) por parte do Estado passou de 20 para $25 \%$ do total dos recursos" (MacDowel, 2007, p. 21)

O rateio da receita proveniente da arrecadação de impostos entre os entes federados representa um mecanismo fundamental para amenizar as desigualdades regionais, na busca de promover o equilíbrio sócio-econômico entre Estados e Municípios. 
Dentre as principais transferências da União para os Estados, o DF e os Municípios, previstas na Constituição, destacam-se: o Fundo de Participação dos Estados e do Distrito Federal (FPE); o Fundo de Participação dos Municípios (FPM); o Fundo de Compensação pela Exportação de Produtos Industrializados - FPEX; o Fundo de Manutenção e Desenvolvimento da Educação Básica e de Valorização dos Profissionais da Educação - Fundeb; e o Imposto sobre a Propriedade Territorial Rural $\mathrm{ITR}^{73}$.

Outro mecanismo de compensação de receitas pela União são as transferências voluntárias. Por meio desse mecanismo, a União se compromete a repassar parte de recursos financeiros aos Estados, Distrito Federal e Municípios por meio da celebração de convênios, acordos, ajustes ou outros instrumentos similares cuja finalidade seja a realização de obras e/ou serviços de interesse comum e coincidente às três esferas do Governo. Pela Lei de Responsabilidade Fiscal, a transferência voluntária deve ocorrer a título de cooperação, auxílio ou assistência financeira, que não decorra de determinação constitucional, legal ou os destinados ao SUS.

Após a Constituição de 1988, os recursos recebidos pelos municípios por meio das transferências fiscais foram desvinculados de gastos específicos, o que significou relativa liberdade dos gestores municipais na elaboração de seus orçamentos, respeitando apenas a obrigatoriedade constitucional de destinar $25 \%$ de suas receitas correntes aos gastos com educação.

\section{II}

A descentralização administrativa deu autonomia aos municípios para elaborar e executar seus orçamentos e partilha fiscal tratou de dar o aporte financeiro para a novas responsabilidades municipais.

Para MacDowell (2007, p. 36), no Brasil, o sistema de transferências intergovernamentais é complexo e contempla vários tipos e finalidades de transferências aos municípios. A principal transferência proveniente do governo federal em termos de importância no total dos recursos correntes dos municípios ainda é o

\footnotetext{
${ }^{73}$ Fonte: http://www.tesouro.fazenda.gov.br/estados municipios/transferencias constitucionais.asp
} 
FPM, seguida do Fundef e do SUS. Ao longo dos anos 1970 e 1980, os municípios dispunham de uma média anual de cerca de 10\% do total de recursos públicos disponíveis para as três esferas de governo; já a partir de 1989 esse percentual começou a elevar-se, passando para um novo patamar em torno de $16 \%$ ao ano e permanecendo em torno dele desde então, o que é positivo ${ }^{74}$.

Observando-se o gráfico elaborado por MacDowell (2007, p. 25), verifica-se a tendência de centralização de recursos na década de 70 (após a Reforma Tributária de 1967), como apontado antes, mas a partir da década de 80, relativo equilíbrio da proporcionalidade de arrecadação entre os entes federados manteve-se até 2004 (ano da nova PNDU), mas com indícios de aumento de receita do governo federal, em detrimento de tendências de do Estados (mais) e dos Municípios (menos).

Gráfico 12 - Evolução da participação dos níveis de governo no total da receita disponível (\%)

\section{Evolução da participação dos níveis de governo no total da receita disponível (\%)}



Fonte: MacDowell (2007).

Observa-se que em um primeiro momento (após a Constituição de 1988, cf. Gráfico 10) o governo federal teve seus recursos reduzidos, mas logo tratou de reverter a situação ${ }^{75}$, conseguindo elevar 0 nível de arrecadação por algumas fontes, como pode-se ver na Tabela 5 . A partir de 1997, o governo federal recuperou parte dos

\footnotetext{
${ }^{74}$ Porém, os municípios entre si apresentam características fiscais diferentes e por isso as mesmas regras não podem ser aplicadas ao conjunto de municípios.

${ }^{75}$ Almeida já põe em discussão a volta de centralização pelo governo federal, mediante os recentes movimentos de controle sobre recursos que estariam fora das transferências constitucionalmente determinadas.
} 
recursos disponíveis por meio da criação de várias contribuições sociais, criando um movimento em direção à re-centralização (Mac DOWELL, 2007. p. 22).

Tabela 5 - Arrecadação tributária federal de 2004-2009

\begin{tabular}{|c|c|c|c|c|c|c|c|c|c|c|c|}
\hline \multicolumn{12}{|c|}{ ARRECADAÇĀO TRIBUTÁRIA FEDERAL NO CONTEXTO DA PNDU DE 2004} \\
\hline ANOS & IR & IPI & IOF & Cofins & CSLL & PIS/Pasep & $\begin{array}{l}\text { Imp. de } \\
\text { import. }\end{array}$ & CPMF & CIDE & $\begin{array}{l}\text { Outros } \\
\text { Tributos }\end{array}$ & $\begin{array}{l}\text { Total } \\
\text { (R\$ } \\
\text { Milhões) }\end{array}$ \\
\hline 2004 & $32 \%$ & $7 \%$ & $2 \%$ & $24 \%$ & $6 \%$ & $6 \%$ & $3 \%$ & $6 \%$ & $2 \%$ & $11 \%$ & 394638 \\
\hline 2005 & $35 \%$ & $7 \%$ & $2 \%$ & $24 \%$ & $7 \%$ & $6 \%$ & $3 \%$ & $8 \%$ & $2 \%$ & $6 \%$ & 422105 \\
\hline 2006 & $35 \%$ & $7 \%$ & $2 \%$ & $23 \%$ & $7 \%$ & $6 \%$ & $3 \%$ & $8 \%$ & $2 \%$ & $7 \%$ & 448801 \\
\hline 2007 & $36 \%$ & $8 \%$ & $2 \%$ & $23 \%$ & $8 \%$ & $6 \%$ & $3 \%$ & $8 \%$ & $2 \%$ & $6 \%$ & 490901 \\
\hline 2008 & $38 \%$ & $8 \%$ & $4 \%$ & $24 \%$ & $9 \%$ & $6 \%$ & $3 \%$ & $0 \%$ & $1 \%$ & $6 \%$ & 497275 \\
\hline 2009 & $38 \%$ & $6 \%$ & $4 \%$ & $24 \%$ & $9 \%$ & $6 \%$ & $3 \%$ & $0 \%$ & $1 \%$ & $8 \%$ & 481249 \\
\hline
\end{tabular}

Fonte: Ministério da Fazenda, 2010 (Valores brutos transformados em porcentagem pela autora)

A descentralização de competências e responsabilidades, e recente "recentralização" de recursos no governo central, combinados com a questão da partilha fiscal entre os entes federativos das últimas duas décadas principalmente, tem sido um verdadeiro torniquete à consecução do pacto federativo nacional.

\begin{abstract}
"O desenho do federalismo feito em 1988 está sendo modificado desde 1994, com a implantação do Plano Real. Como decorrência da necessidade de se manter o controle da inflação, várias políticas foram redesenhadas, promovendo sensíveis e sutis mudanças no arranjo federativo desenhado pela Constituição de 1988. Essas novas políticas aumentaram o volume das receitas federais não-partilhadas com as esferas subnacionais, vincularam receitas estaduais e locais a determinadas funções, em especial educação e saúde, e restringiram a liberdade de alocação de recursos subnacionais, que foi uma das marcas da Constituição de 1988. (SOUZA, 2003, p. 145)
\end{abstract}

Há uma tendência de os governos municipais atentarem para a importância de cumprirem seu papel arrecadador dentro do federalismo fiscal, e algumas medidas, como a simplificação dos aspectos burocráticos na aquisição de empréstimos, a ampliação da autonomia dos municípios sobre alguns tributos, a parceria e cooperação da União e dos governos na execução de determinadas políticas podem apontar para uma perspectiva mais "cooperativa" na parte que cabe a cada esfera de governo com relação ao financiamento do desenvolvimento urbano. 


\section{III}

Além de parte dos repasses fiscais, as fontes de financiamento da política urbana podem ser os empréstimos público ou privado, obtidos junto aos bancos públicos, por meio de fundos como FGTS e FAT operados pela CEF, BNDES), ou agencias de fomento internacionais, como o BID e o BIRD.

No período militar, viu-se um grande volume de investimentos públicos federais injetados em programas urbanos. Nas décadas de 1980 e 1990 as sucessivas crises econômicas fizeram recrudescer os investimentos públicos, e posteriormente, o ajuste fiscal para conter o endividamento dos Estados e Municípios com a Lei de Responsabilidade Fiscal, aprovada em $2000^{76}$, somam fortes constrangimentos ao financiamento da política urbana.

"Com as políticas de ajuste fiscal, o financiamento ao desenvolvimento urbano encontra, ao longo dos últimos anos, duas ordens de constrangimentos. Em primeiro lugar, a pura e simples retração dos investimento públicos diretos. Em segundo, a restrição da capacidade de endividamento de estados e municípios, que leva ao contingenciamento de recursos destinados ao financiamento do setor público" (MINISTÉRIO DAS CIDADES, 2004a, p, 19).

O contingenciamento de empréstimos públicos e privados para implementação de programas urbanos que exigem altos volumes de contratações, como programas habitacionais e de saneamento, tem levado à busca de alternativas dentro da própria estrutura governamental, como a contratação de recursos onerosos, ampliação das possibilidades de empréstimos a partir de outras fontes além do FGTS, e contado com recursos provindos também do OGU (Orçamento Geral da União).

Tabela 6 - Recursos financeiros para habitação (em R\$ 1 milhões) - Governo Federal 2003/2004

\begin{tabular}{|l|c|c|}
\hline Fonte dos Recursos & $\mathbf{2 0 0 3}$ & $\mathbf{2 0 0 4}$ \\
\hline Fundo de Garantia por Tempo de Serviço & $2.761,00$ & $4.050,00$ \\
\hline Caixa Econômica Federal & 552,52 & $1.792,77$ \\
\hline Fundo de Arrendamento Residencial & $1.116,60$ & $1.180,00$ \\
\hline Orçamento Geral da União & 492,73 & 670,48 \\
\hline Fundo de Amparo do Trabalhador & 164,29 & 597 \\
\hline Fundo de Desenvolvimento Social & 0 & 542 \\
\hline TOTAL & $\mathbf{5 . 0 8 7 , 1 4}$ & $\mathbf{8 . 8 3 2 , 2 5}$ \\
\hline
\end{tabular}

Fonte: MINISTÉRIO DAS CIDADES, 2004a.

\footnotetext{
${ }^{76}$ A Lei Complementar no 101, de 4 de maio de 2000, intitulada Lei de Responsabilidade Fiscal - LRF, estabelece normas de finanças públicas voltadas para a responsabilidade na gestão fiscal, mediante ações em que se previnam riscos e corrijam desvios capazes de afetar o equilíbrio das contas públicas, destacando-se o planejamento, o controle, a transparência e a responsabilização como premissas básicas. Fonte: Ministério da Fazenda, Disponível em $<$ http://www.tesouro.fazenda.gov.br/hp/lei responsabilidade fiscal.asp > Acesso em: 15.06.2010.
} 
Outra fonte de recursos para a Política Nacional de Desenvolvimento Urbano são as Parcerias Público-Privadas (PPPs), com Lei em tramitação desde 2004, ampliando as possibilidades de financiamentos habitacionais, de transportes e infraestrutura, mas ressaltando-se o caráter de complementaridade, não de substituição do papel do poder público de financiador do desenvolvimento urbano e regulador dos processos especulativos e excludentes do mercado imobiliário, fundiários, enfim, dos interesses tanto econômicos quanto sociais do desenvolvimento urbano.

\section{IV}

Além dessas possibilidades, os municípios contam ainda com os institutos tributários e financeiros do Estatuto da Cidade, como o imposto sobre a propriedade predial e territorial urbana - IPTU progressivo no tempo; a contribuição de melhoria, e incentivos e benefícios fiscais e financeiros.

O IPTU progressivo no tempo "é muito mais um instrumento de indução do aproveitamento das terras urbanas, do que um instrumento para aumentar as receitas do Município". Já o IPTU Progressivo já pode ser mais entendido como um instrumento fiscal, pelo princípio de equivalência entre a alíquota e a área do imóvel.

A Contribuição de Melhoria, larga e historicamente mal-interpretadas como mecanismo reducionista de "recuperação de mais valia" (FURTADO, 2007), tem sido entendido como "benfeitorias" ou benefícios realizadas pelo empreendedor em determinada obra urbana, podendo assumir interpretações variadas, como contrapartidas, ou mesmo de que a própria obra é um contribuição de melhoria Os incentivos fiscais e financeiros são ainda inespecíficos no Estatuto, mas juridicamente podem relacionar-se a incentivos do poder público ao empreendedor na preservação do patrimônio histórico e ambiental.

Outros instrumentos de recuperação da "mais-valia" são a Outorga Onerosa do Direito de Construir (o "solo criado", que trabalha em cima dos coeficientes de aproveitamento) e as Operações Urbanas Consorciadas, que podem gerar recursos para o poder público a partir de contrapartidas dos empreendedores. 
A idéia sobre o qual esses instrumentos estão fundados é o da recuperação da valorização fundiária pelo Poder Público, a partir da dinamização da urbanização.

\subsubsection{Considerações sobre 0 federalismo fiscal e a competição intergovernamental}

Como visto, são muitos os fatores que concorrem dentro do arranjo federativo para a formulação e implementação da política urbana. No Brasil, as relações entre o governo central e os governos "locais" historicamente foram marcadas pela barganha e pelo clientelismo na divisão de poderes entre o governo central e os estados e regiões, ou por concentração de poderes no nível central, superando ou "agregando" os interesses locais.

A começar pela trajetória histórica do federalismo no Brasil, viu-se que foi marcada mais pela competição entre os entes federados do que pela cooperação. $A$ autonomia dos governos subnacionais passou por momentos de maior ou menor transferência de poder decisório conforme o período político de centralização ou descentralização.

Durante governo militar, apesar da centralização política, houve, a partir de determinado momento, uma descentralização fiscal que aumentou o volume de transferências para os Estados Na nova Constituição (1988), estabeleceu-se a partir dos Artigos 157 a 162, a repartição das receitas tributárias entre União, estados e municípios (PÓLIS, 2001) ${ }^{77}$.

A definição da repartição de tributos e despesas, se por um lado aumentou a receita dos governos subnacionais, por outro, também veio acompanhada de despesas, principalmente no nível municipal, que ficou com a atribuição principal de promoção e execução das políticas urbanas.

Atualmente, a forma do federalismo fiscal também tem grandes impactos sobre a política urbana, principalmente a intra-urbana, de atribuição executiva do município,

\footnotetext{
${ }^{77}$ PÓLIS, INSTITUTO. Estatuto da Cidade - guia para implementação pelos municípios e cidadãos.
} São Paulo: Instituto Polis, 2001. 
que a partir de 1988 se tornou mais um ente federativo passando a responder por mais atribuições do desenvolvimento urbano.

Por isso, a cooperação e a coordenação federativa tornam-se essenciais para que as novas regras constitucionais passem do papel à ação planejada e executada com a colaboração dos três governos. Mas a dificuldade de manter os gastos públicos dentro de um orçamento compatível com a arrecadação ou recebimento por transferências tem gerado competição entre os níveis de governo, ou seja, a guerra fiscal.

Para Souza (2003), o objetivo do federalismo cooperativo está longe de ser alcançado por duas razões principais: a primeira está nas diferentes capacidades dos governos subnacionais de implementarem políticas públicas, dadas as enormes desigualdades financeiras, técnicas e de gestão existentes; e a segunda está na ausência de mecanismos constitucionais ou institucionais que estimulem a cooperação, tornando o sistema altamente competitivo.

Costa (2007) considera que o entendimento do funcionamento real do federalismo, além do fiscal, passa pelas principais instituições políticas e administrativas, como os partidos, as casas legislativas e órgãos executivos em todos os âmbitos da federação (nacional, estadual, municipal), e o poder judiciário, a burocracia.

\subsection{INSTRUMENTOS LEGAIS}

\subsubsection{Institutos jurídico-urbanísticos e sua trajetória histórica no Brasil}

$\mathbf{I}$

$\mathrm{Na}$ relação entre os estudos urbanos e estudos jurídicos, Fernandes $(2008)^{78}$ destaca a necessidade de superação da visão do direito como simples "instrumento técnico" de solução de conflitos e problemas da ilegalidade urbana, e colocar a lei urbanística no patamar de processo sociopolítico, como componente da arena de conflitos e negociações que envolvem a noção de função social da cidade e da propriedade urbana.

\footnotetext{
${ }^{78}$ FERNANDES, E. Reforma urbana e reforma jurídica no Brasil: duas questões para reflexão. lin Costa, Geraldo Magela Costa e Jupira Gomes de Mendonça (orgs) Planejamento urbano no Brasil: trajetória, avanços e perspectivas, Belo Horizonte C/Arte. 2008
} 
O autor destaca ainda que a relação entre leis urbanísticas e políticas públicas passa também pelo desafio de aproximação entre os institutos jurídicos e os objetivos declarados das políticas públicas. Os processos econômicos e sócio-políticos que implicam na sua implementação implicam superação de descompassos entre as aspectos conceituais e pragmáticos, de aplicação da lei na gestão urbana. Nesse sentido, a Reforma Urbana implica também na Reforma do Direito Urbanístico.

Fernandes (2008) aponta duas questões essenciais de partida, que são: o plano diretor como instituto jurídico do plano urbanístico, que encampa as complexidades do direito de propriedade no desenvolvimento urbano; e o segundo, da dinâmica do pacto federativo, remetendo às questões da instituição jurídica do "Município", introduzidas a partir da Constituição de 1988, gerando descompassos entre as responsabilidades de gestão, frente às problemáticas da urbanização, cuja escala seria então metropolitana, ou da problemática ambiental, cuja escala seria as micro-bacias etc.

\subsubsection{Legislação à época da PNDU de 1975}

\section{Lei Complementar no 14, de 1973 - Instituição das Regiões Metropolitanas}

O contexto à época da primeira PNDU como já visto, era de crescimento acelerado da urbanização, grande parte desse contingente populacional direcionandose às metrópoles, que viviam o contraste da riqueza econômica da industrialização com a pobreza crescente de grande parte da população que ocupava suas periferias.

A necessidade de regular o processo de expansão metropolitana e de proporcionar a gestão integrada dos problemas comuns das cidades conurbadas era sentida tanto pelas esferas administrativas da União, dos Estados e dos Municípios, como eram reivindicados nos debates da sociedade, como já pautado no Seminário de Habitação e Reforma Urbana.

A institucionalização dessas regiões foi objeto de legislação específica na Carta de 1967, porém sua efetivação teve lugar somente em 1973. Um ano depois, pela lei Complementar no 20, de 01.07.1974, foi criada a Região Metropolitana do Rio de Janeiro, aproveitando a oportunidade da fusão dos antigos Estados da Guanabara e do Rio de Janeiro" (MINISTÉRIO DO INTERIOR, 1975, p. 10). 
A Constituição de 1967 já previa a possibilidade da instituição de regiões metropolitanas pela União:

$\S 10$ - A União, mediante lei complementar, poderá estabelecer regiões metropolitanas, constituídas por Municípios que, independentemente de sua vinculação administrativa, integrem a mesma comunidade sócioeconômica, visando à realização de serviços de interesse comum. (BRASIL, 1967) ${ }^{79}$.

Considerado, portanto, um instrumento de fundamental importância para o fortalecimento das ações no campo do desenvolvimento urbano foi promulgada a Lei Complementar no 14 de 08.06.73, que estabeleceu as Regiões Metropolitanas de São Paulo, Belo Horizonte, Recife, Salvador, Curitiba, Belém e Fortaleza.

As Leis Complementares №s 14/73 e 20/74 determinaram quais os municípios que comporiam as regiões metropolitanas do País e delegaram aos Estados a tarefa de implantar os serviços comuns de interesse metropolitano. Fixaram ainda que em cada RM haveria um Consellho Consultivo, criados a nível estadual. (MINISTÉRIO DO INTERIOR, 1975).

Oportunamente criada no momento em que a gestão dos problemas urbanos exigia parcerias intermunicipais e supramunicipais, a responsabilidade que recaiu sobre os Estados no tocante à gestão metropolitana não foi acompanhada de contrapartidas financeiras, o que dificultou a manutenção da estrutura prevista (conselhos, planos, serviços) em Lei para fazer funcionar essas instâncias administrativas dos problemas urbanos.

Acredita-se que a Lei ignorou experiências de gestão consorciada que já vinham acontecendo, impondo legalmente os novos arranjos metropolitanos regionais, que expressava interesse de investimentos prioritários nessas regiões, uma vez que os seus municípios componentes teriam privilégios na obtenção de recursos federais e estaduais.

A Constituição de 1988 delegou definitivamente aos estados a prerrogativa de criação das Regiões Metropolitanas, com os mesmo objetivos de "exercício de funções públicas de interesse comum":

\footnotetext{
${ }^{79}$ BRASIL. Constituição da República Federativa do Brasil, 1967.
} 
$\S 3$ 3․ Os Estados poderão, mediante lei complementar, instituir Regiões Metropolitanas, aglomerações urbanas e microrregiões, constituídas por agrupamentos de municípios limítrofes, para integrar a organização, o planejamento e a execução de funções públicas de interesse comum." (BRASIL, 1988).

\section{Lei № 1.817, de 1978, sobre o Zoneamento industrial na região Metropolitana de São Paulo}

Ainda no mesmo contexto de consolidação da base industrial nacional, preocupação muito presente do texto da PNDU de 1975, e que influenciou a criação das regiões metropolitanas, a Lei de Zoneamento Industrial de São Paulo foi criada como um instrumento de regulação estatal da ocupação do solo urbano por essa função econômica.

O próprio texto da PNDU já alertava sobre os problemas decorrentes da excessiva concentração industrial na região Sudeste e falta de zoneamento adequado:

"No Brasil, a Região Sudeste é a área que apresenta aspectos de poluição mais agudos, sobretudo face à excessiva concentração industrial em certas áreas metropolitanas, sem zoneamento adequado, assim como o grande número de veículos existentes nos aglomerados urbanos (...)

Entres as fontes ativas de poluição, destacam-se a indústria e os setores de transportes como os maiores contribuintes para a poluição do ar, ao passo que a indústria e o setor doméstico predominam na poluição da água"(...)

As condições locais de poluição de origem industrial são agravadas pelo fato de na maioria dos Municípios da Região, assim como nos de São Paulo, não existir uma política ativa de implantação de centros industriais, capaz de disciplinar a ocupação industrial da terra".

(MINISTÉRIO DO INTERIOR, 1975, p. 28-29)

A Lei foi criada, então, alguns anos após esses diagnósticos, e estabeleceu "os objetivos e as diretrizes para o desenvolvimento industrial metropolitano" e disciplinou "o zoneamento industrial, a localização, a classificação e o licenciamento de estabelecimentos industriais na Região Metropolitana da Grande São Paulo".

A Lei intencionava tanto fazer frente ao processo de ocupação irregular da terra pelas indústrias, organizando a localização de forma danosa ao ambiente, como por outro lado, pela adequação do zoneamento, atrair grandes indústrias (indústrias de vocação ou especialização metropolitana), e com isso garantir os investimentos de infra-estrutura para manter a vitalidade do Parque Industrial regional, e estimular a 
descentralização de estabelecimentos industriais, que não fossem de especialização ou de vocação metropolitana, para outras regiões.

A legislação previu o "zoneamento ambiental", com áreas de proteção aos mananciais metropolitanos, e classificou as zonas de uso industrial (e os índices urbanísticos), determinou quais tipos de indústrias poderiam se instalar na região, e delimitou especificamente as áreas de permissão de instalação de novas indústrias em cada município, que teriam uma compensação financeira pela atividade industrial recebida.

Pode-se dizer que o significado dessa Lei é relevante no momento de expansão urbana a partir da ocupação industrial, tanto de regular esse processo de uso do solo em uma região já densamente tomada - sofrendo com sérios problemas de ocupação irregular imobiliário, habitacional e nesse caso, agravado pelo dano ambiental - como foi para direcionar o desenvolvimento econômico das áreas contíguas à concentração na cidade de São Paulo, que já começava a dar sinais da deseconomias de aglomeração.

\section{Lei 6766 , de 1979, sobre o Parcelamento do Solo Urbano}

Como conseqüência direta do processo de urbanização acelerado das décadas de 60 e 70 - no qual a indústria concentrada em São Paulo teve grande influência - e do tipo de tratamento dado ao desenvolvimento urbano, que claramente priorizava o atendimento dos interesses governamentais do desenvolvimento econômico, contraditoriamente - ou convenientemente - o processo de uso e ocupação do solo nas periferias ocorreu à revelia de qualquer regulação urbanística, à margem da cidade urbanizada, provida de infra-estrutura.

Viu-se a ocupação periférica das franjas urbanas, das áreas distantes dos centros, das margens de rios, de áreas de proteção, em condições precárias ou inexistentes de habitação, saneamento, transportes, ou seja, e a proliferação de loteamentos populares sem mínima infra-estrutura, a alternativa habitacional que restava à população de baixa renda, excluída de qualquer processo legal de ocupação urbana. 
A Lei Federal № 6.766 foi criada em 1979 com o intuito de fazer frente a esses processos e disciplinar o parcelamento, o uso e a ocupação do solo urbano, determinando especificamente as condições infra-estruturais, físicas e locacionais para projetos de loteamentos e desmembramentos. Era facultativo aos Estados e Municípios criarem leis complementares que atendessem a suas especificidades locais e regionais, mas as aprovações do parcelamento urbano se deviam às municipalidades. A Lei, que ainda vigora, contempla em seu escopo:

a) Modalidades de parcelamento

b) Requisitos urbanísticos para loteamento;

c) Responsabilidades do loteador e do Poder Público;

d) Elementos do projeto de loteamento e desmembramento;

e) Aprovação e registro do Parcelamento do Solo;

f) Define as competências do Município e do Estado para o parcelamento do solo urbano;

g) Relações contratuais: loteador e adquirentes de lotes

h) O papel do Poder Público na Regularização de Parcelamento Irregular;

i) Critérios específicos para a regularização de parcelamentos de interesse social promovidos pelo Poder Público;

j) Infrações e crimes de Parcelamento do Solo;

k) Requisitos para a modificação de área rural para área urbana para fins de implantação de parcelamento urbano". (SAULE Jr, 2008).

Se por um lado a Lei veio para conter ao crescente cenário de informalidade que se construía diariamente nas grandes metrópoles e organizou melhor a produção de lotes urbanos para o mercado formal, acabou por gerar uma situação ambígua. Conforme Fernandes (2008), sua trajetória, assim como a do conjunto da legislação urbanística nacional, tem sido marcada pelo foco na tentativa de regular o solo urbano, sendo na verdade a própria "ordem jurídica uma dos principais fatores que têm determinado muitos dos problemas urbanos, sócio-ambientais que as políticas tentam enfrentar - começando com o fenômeno da ilegalidade urbana" (FERNANDES, 2008, p. 124), fazendo prevalecer mais uma vez os interesses econômicos sobre os sociais. Ainda que tenha previsto loteamentos para baixa renda, era mais um caráter de "concessão" do que enfrentamento real do problema da cidade "irreal".

"Apesar de estabelecer a possibilidade de parâmetros urbanísticos reduzidos para os parcelamentos de baixa renda, não possui os requisitos urbanísticos e ambientais suficientes, no sentido de viabilizar a regularização fundiária do enorme passivo sócio-ambiental existente no país, dificultando ainda mais o acesso à terra legal, barata e urbanizada aos mais pobres, favorecendo a desqualificação espacial e propiciando o agravamento do quadro de irregularidade fundiária no país" (GOUVEIA e RIBEIRO, 2010). 


\subsubsection{Legislação à época da PNDU de 2004}

\section{Lei Federal 10.257 de 2001: Estatuto da Cidade}

Estatuto da Cidade (Lei Federal 10.257 de 2001), como já visto, é o marco regulatório da política nacional de desenvolvimento urbano que regulamenta os artigos 182 e 183 da Constituição Federal e estabelece os novos parâmetros e diretrizes da política urbana nacional.

Assim como o capítulo constitucional sobre a política urbana, o Estatuto também é fruto dos movimentos nacionais de luta pela reforma urbana, com suas bases lançadas desde antes do período militar. Treze anos pós a aprovação do capítulo constitucional e longos embates entre os diversos interesses em jogo, porquanto se propunha mudanças significativas na forma de apropriação do espaço e da gestão urbana, o Estatuto finalmente foi aprovado introduzindo um caráter inovador do ponto de vista jurídico, normativo e instrumental na formulação das políticas e planejamento urbano no Brasil.

O significado da aprovação dessa Lei, muito mais que uma conquista do movimento de luta pela reforma urbana, representa um marco para a reflexão histórica e ação presente da atuação do Estado no processo de desenvolvimento intra-urbano, no sentido de que propõe renovação das práticas de planejamento nas cidades, tentando romper com a herança antidemocrática, clientelística, privatista, funcional e centralizada da formulação e gestão das políticas públicas nacionais.

E isso se expressa nas diretrizes básicas do direito integral à cidade, que em suma, tratam da gestão democrática, da cooperação intergovernamental, do planejamento do desenvolvimento das cidades, da oferta de equipamentos urbanos e na ordenação e controle do uso do solo, recuperação da mais-valia imobiliária, e isonomia entre os agentes públicos e privados, pra citar alguns destaques, preconizando uma concepção eminentemente democrática para formulação da política urbana e na forma de gestão e apreensão social do espaço intra-urbano. 
O instrumento básico para implementação dessas diretrizes nas cidades é o Plano Diretor ${ }^{80}$. O planejamento municipal, na forma de elaboração dos planos diretores participativos passa a contar com os novos institutos tributários financeiros e jurídico-políticos regulamentados pelo Estatuto.

"O Plano Diretor na sua nova concepção determina o conjunto de princípios e regras orientadoras da ação dos agentes que constroem e utilizam o espaço urbano. O Plano Diretor parte de uma leitura da cidade real, envolvendo temas e questões relativos aos aspectos urbanos, sociais, econômicos e ambientais, que embasa a formulação de hipóteses realistas sobre as opções de desenvolvimento e modelos de territorialização. O objetivo do Plano Diretor não é resolver todos os problemas da cidade, mas sim ser um instrumento para a definição de uma estratégia para a intervenção imediata, estabelecendo poucos e claros princípios de ação para o conjunto dos agentes envolvidos na construção da cidade, servindo também de base para a gestão pactuada da cidade. Desta forma, é definida uma concepção de intervenção no território que se afasta da ficção tecnocrática dos velhos Planos Diretores de Desenvolvimento Integrado, que tudo prometiam (e nenhum instrumento possuíam para induzir a implementação do modelo idealizado proposto!) e nada faziam (PÓLIS, 2001, p. 40).

\section{O Art. 4ำ do Estatuto da Cidade estabelece o Plano Diretor como um dos} "instrumentos da política urbana", que conta ainda com:

I - planos nacionais, regionais e estaduais de ordenação do território e de desenvolvimento econômico e social;

II - planejamento das regiões metropolitanas, aglomerações urbanas e microrregiões;

III - planejamento municipal, em especial:

a) plano diretor;

b) disciplina do parcelamento, do uso e da ocupação do solo;

c) zoneamento ambiental;

d) plano plurianual;

e) diretrizes orçamentárias e orçamento anual;

f) gestão orçamentária participativa;

g) planos, programas e projetos setoriais;

h) planos de desenvolvimento econômico e social;

\footnotetext{
80 Além do planejamento municipal, o Estatuto regulamenta ainda o planejamento nacional, determinando os planos a serem desenvolvidos por cada nível, ou em cooperação entre estes, que são os planos nacionais, regionais e estaduais de ordenação do território e de desenvolvimento econômico e social; e também o planejamento das regiões metropolitanas, aglomerações urbanas e microrregiões, que são os outros instrumentos do planejamento urbano e regional. Porém, a concentração de esforços tem se dado na elaboração em massa dos planos diretores participativos, obrigatórios para municípios acima de vinte mil habitantes, mas incentivado a todos os municípios pelo Ministério das Cidades.
} 
Vê-se que nas outras escalas territoriais - nacional, regional, estadual, regiões metropolitanas, aglomerações urbanas e microrregiões - não são excluídos os planos e o planejamento, dedicado principalmente a regiões metropolitanas e municípios, que contam ainda com outros instrumentos complementares aos planos diretores, observando-se os aspectos ambientais, orçamentários e de gestão, dentro de uma visão mais holística do planejamento.

Diante dessa "nova concepção" dos Planos Diretores, o Estatuto da Cidade e seus instrumentos são os recursos do planejamento municipal para redirecionar o desenvolvimento urbano. Os instrumentos jurídicos do Estatuto da Cidade para os PDS, são normativos e indutivos, e se colocam como ferramentas para promoção do desenvolvimento urbano, com vistas ao atendimento à determinação constitucional da "função da cidade e da propriedade urbana. Os instrumentos assim estão dispostos, conforme Artigo 4ํㅡㄹ do Estatuto:

IV - institutos tributários e financeiros:

a) imposto sobre a propriedade predial e territorial urbana - IPTU;

b) contribuição de melhoria;

c) incentivos e benefícios fiscais e financeiros;

$V$ - institutos jurídicos e políticos:

a) desapropriação;

b) servidão administrativa;

c) limitações administrativas;

d) tombamento de imóveis ou de mobiliário urbano;

e) instituição de unidades de conservação;

f) instituição de zonas especiais de interesse social;

g) concessão de direito real de uso;

h) concessão de uso especial para fins de moradia;

i) parcelamento, edificação ou utilização compulsórios;

j) usucapião especial de imóvel urbano;

I) direito de superfície;

m) direito de preempção;

n) outorga onerosa do direito de construir e de alteração de uso;

o) transferência do direito de construir;

p) operações urbanas consorciadas;

q) regularização fundiária;

r) assistência técnica e jurídica gratuita para as comunidades e grupos sociais menos favorecidos;

s) referendo popular e plebiscito;

VI - estudo prévio de impacto ambiental (EIA) e estudo prévio de impacto de vizinhança (EIV).

$\S 10$ Os instrumentos mencionados neste artigo regem-se pela legislação que lhes é própria, observado o disposto nesta Lei. 
$\S 20$ Nos casos de programas e projetos habitacionais de interesse social, desenvolvidos por órgãos ou entidades da Administração Pública com atuação específica nessa área, a concessão de direito real de uso de imóveis públicos poderá ser contratada coletivamente.

$\S 30$ Os instrumentos previstos neste artigo que demandam dispêndio de recursos por parte do Poder Público municipal devem ser objeto de controle social, garantida a participação de comunidades, movimentos e entidades da sociedade civil.

Os instrumentos de uso do solo, a gestão urbana e a regularização fundiária são o tripé sobre o qual se assentam a força e as inovações do Estatuto. São instrumentos inovadores no cenário urbano nacional, (i) de indução do desenvolvimento, (ii) de financiamento da política urbana, (iii) de regularização fundiária e (iv) instrumentos de democratização da gestão urbana. No primeiro conjunto, a evidente interação entre regulação urbana é tratada por meio de dispositivos que procuram inibir a especulação imobiliária e garantir a função social dessas propriedades urbanas.

O segundo conjunto de instrumentos trata da regularização fundiária de áreas ocupadas e não regularizadas. Os instrumentos de financiamento dizem respeito a arrecadação de impostos e capacidade de recuperação de mais-valia e estabelecimento de parcerias público-privadas em empreendimentos urbanos. Os instrumentos da gestão democrática garantem a participação dos diversos atores sociais no planejamento municipal, e isso se dá diretamente no processo de elaboração dos planos diretores participativos.

$\mathrm{Na}$ nova constituição o plano diretor é claramente expresso como o "instrumento básico" da política urbana, ou seja, é por meio dele que as diretrizes da política nacional de desenvolvimento urbana deveriam se implementar, contendo os instrumentos - ou institutos - mais adequados à realidade de cada município. No entanto, a realidade de aplicabilidade dos planos, bem como desses instrumentos é ponto crítico atualmente ${ }^{81}$.

Outro conjunto de instrumentos, os de Gestão Democrática da Cidade, podem ser entendidos como as ferramentas do "controle social sobre o planejamento urbano", que na própria concepção do Plano Diretor, é denominado Plano Diretor Participativo.

\footnotetext{
${ }^{81}$ Há críticas de que essa elaboração massiva acabe em planos elaborados a "toque de caixa", sem o necessário processo reflexivo e de debate participativo que de fato causem impactos positivos no desenvolvimento urbano.
} 
São eles: a Conferências da Cidade; os Conselhos da Cidade; as Audiências Públicas; os Estudos de Impacto de Vizinhança; o Orçamento Participativo; a Iniciativa Popular; e o Plebiscito.

No entanto, apesar dos celebrados avanços, o EC contém ainda dispositivos pendentes, cuja aplicação fica alongada no tempo e ainda sujeita a uma diversidade de regulamentações complementares - jurídicas, urbanísticas, ambientais e administrativas. Prevê-se nesse processo de transição um embate entre os interesses de manutenção do status quo da atual situação urbana (fragmentação, exclusão, segregação) e as forças de renovação das concepções e estruturas que aportam esse processo $^{82}$.

\begin{abstract}
"As forças contrárias à implementação da função social da propriedade, seja na sociedade civil, seja no interior do poder judiciário, legislativo ou executivo têm usado diversos artifícios para protelar sua aplicação. A Constituição Federal de 1988 exigiu uma lei complementar — o Estatuto da Cidade - que foi aprovada apenas 13 anos depois. A Constituição e o próprio Estatuto exigiram ainda que a função social da propriedade e outros preceitos se subordinassem ao Plano Diretor municipal. A maior parte dos PDs municipais, por sua vez, está remetendo os instrumentos que regulam a função social da propriedade para lei municipal complementar. Muitos municípios brasileiros ainda não têm aprovadas essas leis complementares e muitos elaboraram PDs genéricos, cheio de boas intenções, mas sem efetividade" (MARICATO, 2010).
\end{abstract}

O que se esperava que fosse um fecho de um ciclo de lutas pela almejada reforma urbana, tem sua força executiva transferida para um novo processo de criação de política enquanto lei, com força executiva: os planos diretores municipais precisam ser aprovados dentro do âmbito legislativo local, e estão sujeitos aos mesmos processos de negociações, articulações e combinações dentro das instituições do sistema federativo nacional. Ainda carente de clareza, o texto integral do Estatuto deixa lacunas que precisam ser mais precisamente definidas, principalmente na forma de negociação legal e institucional para que o pacto federativo ocorra de fato.

\title{
LEI № 11.107, de 2005 - Lei dos Consórcios Públicos
}

No rol das legislações que dão suporte jurídico para que as diretrizes da PNDU possam ser implementadas, a Lei dos Consórcios Públicos entra como um importante

\footnotetext{
${ }^{82}$ Verifica-se aí uma vulnerabilidade do Estatuto, que é a possibilidade de adotarem-se mediações que reduzem muito, quando não, anulam o impacto dos instrumentos de efetivação da Função Social da Propriedade (MARTINS, 2004).
} 
instrumento de apoio ao pacto federativo, no que regulamenta o Artigo 241 da CF1988, que já determinava que:

Art. 241. A União, os Estados, o Distrito Federal e os Municípios disciplinarão por meio de lei os consórcios públicos e os convênios de cooperação entre os entes federados, autorizando a gestão associada de serviços públicos, bem como a transferência total ou parcial de encargos, serviços, pessoal e bens essenciais à continuidade dos serviços transferidos. (BRASIL, 1988).

A resolução de determinados problemas urbanos muitas vezes extrapola a esfera de ação de um município. Ou mesmo a execução de determinado encargo municipal pode ser melhor presta quando realizada em parcerias, dadas as limitações financeiras, de recursos humanos e políticos, que a grande maioria dos municípios brasileiros sofre. Soluções em parceria e potencialização de recursos sãos as motivações principais para o estabelecimento de um consórcio, sejam intermunicipal, seja com a participação dos demais níveis de governo.

A aprovação da Lei dos Consórcios Públicos ${ }^{83}$ em 1996 avança na regulamentação da contratação se consórcios públicos para a realização de serviços de interesse comum e na definição de normas para sua execução, como também as possibilidades de finalidades de consórcios, bem como os procedimentos para criação e desenvolvimento dos processos.

A noção de consorciação por "objetivos de interesse comum" abre uma leque de possibilidades para as associações em diversas áreas, de serviço ou obras públicas, seja saúde ${ }^{84}$, saneamento ambiental (bacias, resíduos sólidos, tratamentos de efluentes), desenvolvimento econômico etc. São possibilidades variadas de consorciação, que podem reforçar a capacidade política e de gestão, principalmente, dos municípios.

Quando celebrados os acordos, os consórcios assumem a condição de "associação pública ou pessoa jurídica de direito privado". A elaboração e ratificação de um "protocolo de intenções" (detalhamento especificado na Lei) é imprescindível ao

\footnotetext{
83 DECRETO № 6.017, DE 17 DE JANEIRO DE 2007. que regulamenta a Lei oㅜ 11.107, de 6 de abril de 2005, que dispõe sobre normas gerais de contratação de consórcios públicos.

84 § 30 Os consórcios públicos, na área de saúde, deverão obedecer aos princípios, diretrizes e normas que regulam o Sistema Único de Saúde - SUS.
} 
celebração do contrato entre as partes interessadas. Uma vez firmado o consórcio ou convênio, passa a integrar a administração indireta de todos os entes da Federação consorciados.

Segundo a Lei, para o cumprimento de seus objetivos, o consórcio público poderá desfrutar dos "privilégios" de:

I - firmar convênios, contratos, acordos de qualquer natureza, receber auxílios, contribuições e subvenções sociais ou econômicas de outras entidades e órgãos do governo;

II - nos termos do contrato de consórcio de direito público, promover desapropriações e instituir servidões nos termos de declaração de utilidade ou necessidade pública, ou interesse social, realizada pelo Poder Público; e

III - ser contratado pela administração direta ou indireta dos entes da Federação consorciados, dispensada a licitação.

Como relação aos tipos de associações possíveis, verticalmente, a Lei de termina que União somente participará de consórcios públicos em que também façam parte todos os Estados em cujos territórios estejam situados os Municípios consorciados.

Anteriormente à Lei, a cooperação intergovernamental administrativa se dava por meio de convênios e consórcios de natureza privada, havendo já experiências nacionais, mais que eram instrumentos insuficientes. A nova PNDU defende que "o Consórcio Público fortalece a cooperação federativa e dá mais consistência legal aos poder local, além de permitir novos formatos institucionais às parcerias entre Município, Estado, Distrito Federal e União para a gestão associada de serviços públicos, recursos hidrográficos, destinação final de resíduos sólidos, tratamento de esgotos, etc." (MINISTÉRIO DAS CIDADES, 2004 a, p. 26)

A partir dessa Lei, a idéia de compartilhar "responsabilidades", ou a gestão conjunta de determinado problema comum já vem tomando formas mais concretas com a possibilidade e estímulos à criação de consórcios em várias áreas. ${ }^{85}$ Muitas têm sido as iniciativas, principalmente intermunicipais, mas a manutenção e a continuidade dos acordos muitas vezes encontra dificuldades na implementação das ações dos convênios.

${ }^{85} \mathrm{O}$ atual governo criou uma plataforma eletrônica que congrega programas governamentais com possibilidade de serem desenvolvidos por meio de convênios, nas mais diversas áreas. 
O relato de um técnico de uma prefeitura no interior de São Paulo revela que as relações intergovernamentais se estabelecem de fato por meio de ações de interesse comum, ou de acordos nas áreas de competências concorrentes, mas que muitas vezes as divergências partidárias são uma forte entrave a uma maior cooperação entre governos de diferentes níveis. As relações horizontais, entre municípios, parecem mais acessíveis, e recentemente foi possível dar andamento ao primeiro consórcio público intermunicipal da região, na área de manejo de resíduos sólidos.

Outro tipo de parceria nos empreendimentos público são as PPPs (Parcerias Público-Privadas), que tiveram sua regulamentação ainda em 2004, por meio da Lei 11.079/2004, que instituiu normas gerais para licitação e contratação de parceria público-privada no âmbito da administração pública.

A Lei definiu a Parceria público-privada como um contrato administrativo de concessão, na modalidade patrocinada ou administrativa, entre os órgãos da administração pública direta, autarquias, fundações, empresas públicas e outras modalidades de órgão públicos dos três níveis do governo e parceiros privados, envolvendo necessariamente contrapartidas financeiras, com a seguintes ressalvas:

\footnotetext{
$\S 4^{\circ}$ É vedada a celebração de contrato de parceria público-privada: reais):

I - cujo valor do contrato seja inferior a $\mathrm{R} \$ 20.000 .000,00$ (vinte milhões de

II - cujo período de prestação do serviço seja inferior a 5 (cinco) anos; ou

III - que tenha como objeto único o fornecimento de mão-de-obra, o fornecimento e instalação de equipamentos ou a execução de obra pública.
}

No contexto da nova PNDU, a ampliação dos investimentos públicos por meio das Parcerias Público-Privadas constitui uma alternativa importante de financiamento da infra-estrutura em transportes, saneamento e habitação, mas claro, sendo esta uma alternativas não uma regra de financiamento, uma vez que ainda pesa sobre o poder público, principalmente o governo federal, a responsabilidade de boa parte do montante de investimentos para o financiamento do desenvolvimento urbano.

NEVES E RIBEIRO (2006) apontam que as principais tendências para a organização de consórcios são a livre associação de municípios que se organizam segundo características políticas próprias e, de outro lado, uma forte indução governamental, segundo as preferências do poder executivo estadual; com ambas incluindo a participação do governo estadual. 
Dentre as características consideradas para o êxito de um consórcio os autores citam: (i) a forte continuidade política e administrativa, que possibilita ambiente político favorável; (ii) otimização e economia em escala; (iii) necessidade de alto grau de coalizão política e confiabilidade entre os participantes.

\section{Projeto de Lei № 3.057/00 - Revisão da Lei 6766/ 79}

Frente à crescente contestação dos termos da Lei 6766/ 79, e seu distanciamento em relação à realidade da maioria das grandes cidades brasileiras desde o final do século XX, uma revisão mais completa da Lei 6.766/79 encontra-se já na forma de Projeto de Lei, № $3.057 / 00^{86}$ e tem como objetivo estabelecer as normas gerais disciplinadoras de parcelamento do solo urbano e de regularização fundiária sustentável de áreas urbanas, visando ter como denominação "lei de responsabilidade territorial". O Projeto de Lei $\mathrm{n}^{\circ} 3.057 / 00$ disciplina as seguintes matérias sobre o parcelamento do solo urbano, conforme destaque de Saule Jr. (2008):

I. "os requisitos urbanísticos e ambientais do parcelamento do solo urbano;

II. as responsabilidades do empreendedor e do Poder Público na implantação e manutenção do parcelamento do solo;

III. os requisitos e critérios sobre o conteúdo e para fins de aprovação do projeto do parcelamento do solo;

IV. as competências do Município e do Estado sobre licenciamento para parcelamento do solo;

V. as exigências para a adoção da licença urbanística e ambiental integrada, bem como para a entrega das obras e da licença final integrada;

VI. critérios para o registro do parcelamentos do solo;

VII. regras para os contratos, relações de consumo e direito do consumidor em parcelamento do solo;

VIII. regularização fundiária sustentável em área urbana, regularização fundiária de interesse social e de interesse específico, demarcação urbanística e legitimação de posse, registro da regularização fundiária de interesse social;

IX. infrações penais, administrativas e civis sobre o parcelamento do solo;

$X$. requisitos e critérios para implantação e regularização do loteamento com controle de acesso; critérios sobre o custo do registro dos títulos inerentes ao parcelamento e regularização fundiária de interesse sócia" (SAULE Jr. , 2008, p. 17)

Segundo Saule Jr, "a lei federal de parcelamento do solo no âmbito da ordem jurídica urbana tem a mesma relevância que o Estatuto da Cidade, por dispor das diretrizes, critérios, procedimentos e instrumentos sobre o parcelamento do solo urbano

\footnotetext{
86 Segundo Saule Jr, (2008, p, 17): "No ano de 2007, o Projeto de Lei $n^{\circ} 3.057 / 00$, que altera a Lei de Parcelamento do Solo Urbano, foi aprovado na Comissão Especial da Câmara dos Deputados, cujo relator foi o deputado Renato Amary (PSDB-SP), e necessita ser aprovado no plenário da Câmara dos Deputados. Este projeto de lei ainda precisa ser apreciado pelo Senado Federal".
} 
para a implantação de núcleos, vilas, conjuntos habitacionais e bairros nas cidades. Essa legislação contém normas fundamentais para o desempenho das funções das cidades" (SAULE Jr., 2008).

Essas mudanças são significativas no novo contexto jurídico-urbanístico da função social da cidade e da propriedade urbana, consagrada com o Estatuto da Cidade, e visam corrigir os passivos sócio-ambientais urbanos das últimas décadas, introduzindo instrumentos de compensação mediante ausência de mecanismos mais próximos à realidade ignorada dos assentamentos informais e ocupações irregulares, juntando-se ao Estatuto no desafio do desenvolvimento urbano mais justo e em igualitário.

Seu longo tempo de tramitação (desde 2000) bem expressa a dimensão do conflito que abarca.

\subsubsection{Considerações sobre a evolução dos institutos jurídico-urbanísticos e o desafio do novo paradigma da propriedade urbana}

A evolução da legislação urbanística nacional é marcada por dois momentos cruciais no contexto das PNDUs.

Na primeira PNDU tem-se o registro da passagem da noção de regulação do solo e normas edilícia como de "remodelação e melhoramentos urbanos", nas décadas de 30 e 40, para a de regulação estatal do uso e ocupação do solo urbano como contenção da irregularidade urbana sobre a terra urbanizada de valor para o mercado e expulsão tácita da baixa renda para as periferias "desurbanizadas e desumanizadas" na década de 70 .

Na segunda PNDU, testemunha-se a tentativa de passagem da noção privatista e individualizada da propriedade para a noção de função social do desenvolvimento urbano, que passa a incluir os excluídos no planejamento do uso e ocupação do solo urbano.

O novo "paradigma" da propriedade urbana calcado nos institutos do Estatuto da Cidade certamente sobrepuja a tanto a esfera físico-territorial do planejamento, uma vez que introduz a gestão democrática como premissa desse processo; quanto a esfera local de decisões sobre o uso de solo, embora seja prerrogativa municipal, no 
sentido que entram na cena da negociação política, financeira e jurídica novos atores, tanto privados como públicos, que se articulam (ou não) na implementação dos instrumentos do Estatuto.

Para Braga (2004), "o Estatuto da Cidade, por um lado, estabelece as bases para a implementação de uma reforma urbana no Brasil e, por outro, coloca todo o peso dessa ação nas mãos do poder municipal, cuja capacidade de efetivar políticas vem sendo solapada pela ruptura unilateral do pacto federativo pela União. Isso determina um impasse no projeto de reforma urbana, que só poderá ser viabilizada se colocada num contexto mais amplo de reforma fiscal federativa".

Assim, as legislações paralelas à de uso do solo, que regulamentam competências, serviços, parcerias, convênios se tornam fundamentais para a implementação das diretrizes da nova PNDU, sem as quais o desafio do novo paradigma da função social das cidades pode ficar restrito mais uma vez à penúria do discurso em lugar da mudança efetiva.

\subsection{INSTRUMENTOS TÉCNICOS}

\subsubsection{Capacitação no contexto da PNDU de 1975}

A ênfase nas disciplinas quantitativas e a crença nos princípios do planejamento racionalista são a pedra de toque dos cursos mais técnicos da época. Novas influências se fazem presentes no planejamento territorial, como exemplificam a política francesa de aménagement $d u$ territoire e as propostas relativas aos pólos de crescimento. Ambas tiveram ampla aceitação nos meios técnicos e serviram de base a propostas de regionalização do território nacional e a estratégias de desenvolvimento.

A capacitação de pessoal e formação de técnicos especializados nas questões urbanas era uma das diretrizes da PNDU de 1975. O planejamento nesse período assume um elevado grau de institucionalidade, e são criados os primeiros de cursos de pós-graduação no país, nas áreas técnicas e em economia.

São implantados os programas de mestrado em planejamento urbano e regional na Universidade Federal do Rio Grande do Sul (1970), na Universidade Federal do Rio de Janeiro (1972) e na Universidade Federal de Pernambuco (1975) (PIQUET e 
RIBEIRO, 1975). São frutos dessa política de de qualificação de pessoal (BNH, SERFHAU e órgãos do governo federal envolvidos com o planejamento urbano ou regional) e produção de dados mais técnicos sobre o território:

- $\quad$ Centro de Desenvolvimento e Planejamento Regional (Cedeplar) UFMG, programa de pesquisa e ensino de pós-graduação na área da Economia Regional (1967)

- Instituto de Pesquisa Econômica Aplicada (IPEA) - diagnósticos da economia nacional (1964)

- $\quad$ Ipea, o Instituto de Planejamento (Iplan) e Centro de Treinamento para o Desenvolvimento Econômico (Cendec) - maior conhecimento da dinâmica de numerosos setores.

- $\quad$ Programas de Pós-graduação em Engenharia- COPPE UFRJ,

Nesses cursos/institutos predominava a formação voltada para as questões nacionais, uma vez que o projeto dos governos militares era transformar o país em uma grande potência no final do século. Acreditava-se que a senda para o desenvolvimento poderia ser trilhada por meio da elaboração de modelos econométricos e demográficos, baseados na geopolítica e na doutrina da Segurança Nacional (PIQUET E RIBEIRO, 2008).

Isso é o que Serra (1991) classifica como "abordagem positivista do processo de decisão", uma vez que seriam característica desse tipo de abordagem o tratamento técnico/científico em metodologias apropriadas e distantes das políticas, do conflito, da negociação: "essas metodologias são por vezes bastante complicadas, propondo algoritmos e fórmulas que pressupõem ser o objeto final da decisão o 'bem-comum'”.

Isso se traduziria em um processo racional linear de: planejar > programas > projetar > construir > ocupar (SERRA, 1991, p.71). O uso ideológico do planejamento racionalista positivista no processo de decisão tende a mascarar a verdadeira face urbana, escondendo "o fato que a cidade é o espaço da confrontação de interesses variados e múltiplos"."A parafernália metodológica proposta tende a obscurecer 0 conflito, fornecendo a cobertura ideológica necessária às decisões tomadas pelos grupos dominantes". Esse era o entendimento de "capacitação" presente no contexto da PNDU de 1975.

A urbanização como um fenômeno novo a ser investigado, suas causas, seus efeitos, seus impactos, e conseqüentemente o planejamento urbano, é compreensível que no contexto da década de 1970 esses temas estivessem em franca ascensão nos 
círculos acadêmicos e de pesquisa, o que justificou a criação de novos cursos e programas de urbanismo em vários Estados, o que foi estimulado no texto da primeira PNDU, assim como o centralismo autoritário também pautou a capacitação e de seus agentes nas diversas esferas do poder público, como forma de garantir o predomínio ideológico do regime.

\subsubsection{Capacitação no contexto da PNDU de 2004}

Passadas algumas décadas da novidade temática chamada urbanização, suas conseqüências e efeitos sobre a cidade certamente contavam com os debates ampliados e constantemente colocados sob novos paradigmas de conhecimento, principalmente nos círculos acadêmicos e militantes.

A capacitação técnica dos agentes públicos parece não ter acompanhado nem os debates, nem a "modernização" dos processos de gestão no nível de compatibilidade com as demanda de serviço e inovações processuais que se deram ao longo dos últimos anos.

Por isso a instrumentação técnica para a nova PNDU tem na capacitação dos agentes públicos (técnica e politicamente) uma ação praticamente transversal, que perpassa todos os setores na tentativa de potencializar a máquina pública como instrumento de cooperação e favorecimento ao desenvolvimento urbano, e não de entrave e subaproveitamento de possibilidades concretas disponibilizadas pelos diversos programas e ações propostos a partir das diretrizes da PNDU.

Isso se materializa no Programa Nacional de Capacitação das Cidades - PNCC, que "promove, coordena e apóia programas e ações voltados para a capacitação de agentes públicos e sociais e para o apoio ao setor público municipal e estadual para o desenvolvimento institucional". ${ }^{87}$

\footnotetext{
${ }^{87}$ Como já foi mais detalhado em tópico anterior, esse item se limita ao debate colocado e referência ao PNCC, como forma de pontuar o tipo de instrumentação técnica pautada pela nova PNDU.
} 


\section{Capítulo 5}




\section{EIXOS COMPARATIVOS: Planos, Programas e ações implementados}

Esse Capítulo apresenta os programas, planos e ações resultantes das diretrizes das PNDUs que foram implementados, no caso da PNDU de 1975, ou estão em implementação, no caso da PNDU de 2004.

Os planos, programas e ações foram escolhidos pela relevância no seu contexto, disponibilidade de dados e informações, e que pudessem fornecer elementos de comparação entre as PNDUs. Como alguns desses programas já foram descritos no Capítulo 2, sobre os conteúdos das PNDUs, serão analisados aqui de forma mais objetiva.

\subsection{Planos, programas e ações PNDU de 1975}

\subsubsection{PLANHAP (Plano Nacional de Habitação Popular)}

Um dos mais conhecidos e estudados programas da década de 70 foi Plano Nacional de Habitação, implementado pelo BNH.

Com a crescente expansão urbana periférica das cidades, as condições habitacionais da população de baixa renda agravavam-se paulatinamente. Não alheio a essa situação, o governo federal também reconhecia o problema, e falava em "déficit habitacional", "número significativo de aglomerados subnormais", "domicílios rústicos" e "condições precárias de habitação". Essa era uma preocupação expressa no texto da PNDU.

Paralelamente à "sensibilização" do Estado ao problema habitacional, o movimento pela Reforma Urbana também tinha como ponto forte em sua agenda a questão habitacional, com a reivindicação de maior atenção do Estado às demandas que o recente processo de urbanização exigia. 
Nesse contexto, o Plano Nacional de Habitação foi instituído na década de 70 (com início da consolidação em 1975), com o objetivo anunciado pelo governo de atender à demanda de habitação de "interesse social" (na verdade, atingiu mais a população de renda acima de 5 salários mínimos) a serem financiadas (por empréstimos) pelos recursos geridos pelo BNH, obtidos do FGT e da Poupança dos trabalhadores (SPBE).

Os principais "parceiros" do BHN na execução dos projetos habitacionais eram as Companhias de Habitação (COHABS) estaduais e municipais, principais agentes operacionais (construção e financiamento) da política habitacional do $\mathrm{BNH}$ na intermediação junto às populações locais.

No texto da PNDU de 1975 , as demandas habitacionais são analisadas regionalmente, observando-se os números e características dos domicílios, quanto ao tipo de construção e as condições de ocupação.

Tabela 7 - Domicílios particulares ocupados em 1970

\begin{tabular}{|l|r|r|r|r|r|r|}
\hline \multicolumn{7}{|c|}{$\begin{array}{c}\text { Domicílios particulares ocupados, por tipo, com discriminação de } \\
\text { Condições de Ocupação, segundo as Regiōes } \\
\text { Número e características dos domicilios permanentes - 1970 }\end{array}$} \\
\begin{tabular}{|l|r|r|r|r|r|} 
Brasil e regiões \\
geográficas
\end{tabular} & \multicolumn{2}{c|}{ Tipo de construção } & \multicolumn{2}{c|}{ Condições de Ocupação } \\
\hline Regióes & Total & Duráveis & Rústicos & Próprios & Alugados & Outros \\
\hline Brasil & $100 \%$ & $74 \%$ & $26 \%$ & $60 \%$ & $19 \%$ & $21 \%$ \\
\hline Norte & $3 \%$ & $44 \%$ & $56 \%$ & $79 \%$ & $10 \%$ & $11 \%$ \\
\hline Nordeste & $29 \%$ & $59 \%$ & $41 \%$ & $66 \%$ & $12 \%$ & $21 \%$ \\
\hline Sudeste & $45 \%$ & $85 \%$ & $15 \%$ & $54 \%$ & $27 \%$ & $20 \%$ \\
\hline Sul & $18 \%$ & $79 \%$ & $21 \%$ & $64 \%$ & $14 \%$ & $22 \%$ \\
\hline Centro-oeste & $5 \%$ & $60 \%$ & $40 \%$ & $59 \%$ & $13 \%$ & $28 \%$ \\
\hline
\end{tabular}

Fonte: IBGE - Censo Demográfico 1970. (MINISTÉRIO DO INTERIOR, 1975).

Os recursos provenientes do FGTS e da Poupança somavam uma ordem vultosa de investimentos, que não destinaram somente às habitações populares como o próprio texto da PNDU aponta: "As análises efetuadas pelo BNH a partir de março de 1974 sobre a distribuição do número de unidades contatadas relevaram uma oferta percentualmente mais elevada, da demanda, nos grupos familiares de maior poder aquisitivo, em decorrência das melhores possibilidades de absorção pelo mercado nessas faixas" (MINISTÉRIO DO INTERIOR, 1975, p. 58). 
O déficit habitacional ${ }^{88}$ para baixa renda no período foi tratado como questão de construção massiva de novas unidades habitacionais pelo BNH. Segundo Bonduki, (2010), "nos vinte e dois anos de funcionamento do BNH, o Sistema Financeiro da Habitação financiou a construção de 4,3 milhões de unidades novas, das quais 2,4 com recursos do FGTS e destas, cerca de 1,2 milhões para população com renda de até 5 salários mínimos e 1,9 milhões com recursos do SBPE, para o mercado de habitação para a classe média". Esse também foi um dos grandes problemas do $\mathrm{SFH}$, a destinação considerável de recursos para a classe média.

No texto da PNDU, foram apontados uma série de fatores para o atendimento à demanda de habitação das camadas mais populares, que são constatações da discrepância entre o discurso e a ação:

- Prestações inacessíveis a mutuários de baixa renda;

- Níveis de poupança dos pretensos mutuários (de baixa e média renda) inadequados;

- Desorganização das COHAB's;

- Dificuldade de obtenção de agentes financeiros para a faixa de renda necessária;

- Dificuldades financeiras dos Estados para contrapartida das obras de infraestrutura e de equipamentos comunitários para implementação do PLANHAP;

- Elevação nos custos dos fatores da produção da habitação, de materiais e de preços dos terrenos;

Diante dessas distorções do sistema, foram propostas uma série de medidas corretivas que facilitassem à população de menor poder aquisitivo acesso à casa própria, em termos de financiamento, de agentes financeiros, de cooperação com os sub-governos através das COHABs, mas os resultados desse programas foram pelo ponto de vista quantitativo exitoso (até isso em parte, porque não conseguiu atender ao déficit existentes), mas do ponto de vista qualitativo desastroso em muitos aspectos, principalmente arquitetônico, locacional, funcional, etc.

\footnotetext{
88 "Como déficit habitacional entende-se a noção mais imediata e intuitiva de necessidade de construção de novas moradias para a solução de problemas sociais e específicos de habitação detectados em certo momento" (MINISTÉRIO DAS CIDADES, 2009, p. 14)
} 
Figura 3 - Conjunto habitacional do Banco Nacional da Habitação (BNH) em Ji - Paraná (RO)

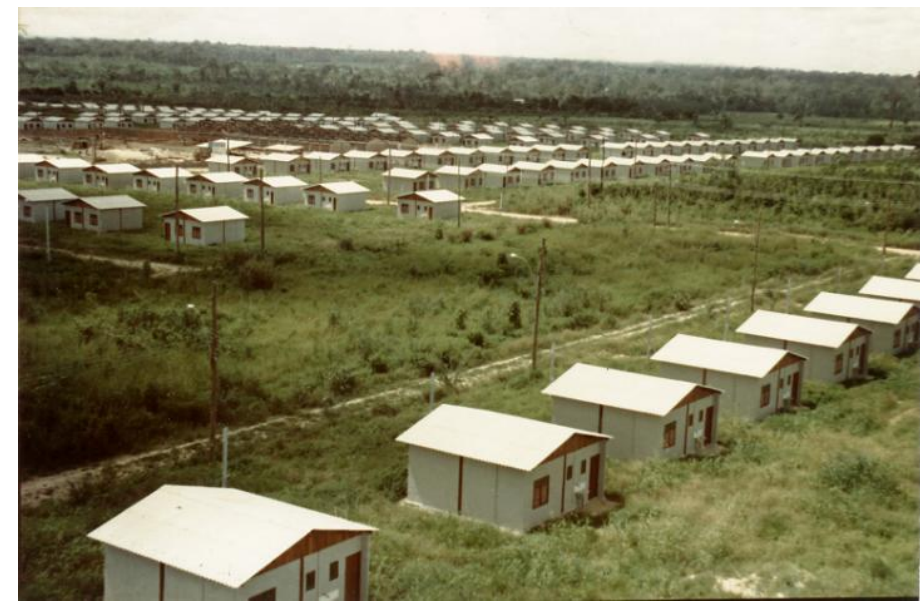

Fonte: Arquivo do IBGE

Apesar das críticas e distorções do sistema, a sua relevância está na importância histórica e referencial que a Política Habitacional do BNH (1964-1986) teve para o País, sendo o primeiro momento em que se estruturou de fato uma política nacional de habitação para o País.

O PLANHAP era um dos muitos programas proposto pelo SFH, comandado pelo $\mathrm{BNH}$, que previam muitos outros tipos de intervenções do governo federal no financiamento, na produção habitação e na provisão de equipamentos urbanos e infraestrutura. Dentre esses diversos programas, serão destacados mais três: O PLANASA (na área de infra-estrutura urbana), o Programa de Cidades Médias (no âmbito regional) e o Projeto CURA (na área de equipamentos urbanos).

\subsubsection{PLANASA (Plano Nacional de Saneamento)}

No começo da década de 70 o problema do saneamento nacional começava a assumir contornos críticos, devido ao processo de urbanização acelerada recente, às ocupações irregulares em áreas marginais, ou mesmo ao surgimento de novas aglomerações e municípios em algumas regiões.

A média nacional de abastecimento de água era de $47 \%$ de domicílios ligados a rede de água e menos de $30 \%$ dos domicílios nacionais eram servidos por redes de esgoto sanitário. A região melhor servida era a sudeste, com médias até acima das nacionais, mas em algumas regiões, como a Sul, que apresentavam um grande 
número de pequenos municípios, a situação era mais precária, e médias do saneamento chegavam a ser muito inferiores que as nacionais, que já eram deficitárias.

Como resposta a essa crise de saneamento nacional, principalmente de abastecimento, o Plano Nacional de Saneamento (PLANASA) foi previsto para implementação de 1975 a 1979, compreendendo operações de financiamento e refinanciamento de estudos, projetos, assistência técnica, execução de obras, bem como a compra de materiais específicos necessários à implantação, ampliação e melhoria dos sistemas de abastecimento de água e esgoto e ao controle da poluição nos centros urbanos do País (MINISTÉRIO DO INTERIOR, 1975, p. 62). As metas eram:

- atendimento de água potável cerca de $80 \%$ da população brasileira em $80 \%$ das regiões;

- atender regiões metropolitanas, capitais e cidades de maior porte com serviços adequados de esgotos sanitários;

- atender com serviços de esgoto mais simples, cidades e vilas de menor porte; (ldem).

A implementação pelo MINTER era prevista para ser realizada em parceria com o Ministério da Saúde, que deveria estabelecer padrões de potabilidade e salubridade para a água e os sistemas a serem implantados. Os recursos proviriam do $\mathrm{BNH}$, via SFS (Sistema Financeiro de Saneamento) - do qual os governos estaduais participavam desde 1968 - e do FAE (Fundo de Financiamentos para Água e Esgoto).

O PLANASA era mantido com recursos do FGTS e com aplicação prioritária na expansão do sistema de abastecimento de água. $\mathrm{Na}$ verdade, a engenharia institucional criada para implementação do Plano, demandava a criação de uma Companhia Estadual de Saneamento (as CESBs), que monopolizavam as concessões de serviço dos municípios daquele Estado. E o FAE, alimentado com recursos do próprio município, arcava com apenas $50 \%$ dos custos, que deveriam ser complementados por empréstimos do BNH com recursos do FGTS.

A parceria entre os diversos níveis de governo era considerada essencial do processo. A parte dos Estados cabia às Companhias Estaduais de Água e Esgoto, e dos Municípios a execução dos serviços. Isso foi uma condição imposta pelo Governo Federal, onde os municípios deveriam entregar às companhias estaduais a gestão dos serviços de abastecimento de água e esgoto, sob a justificativa federal da incapacidade municipal (técnica e financeira) de conduzir esses serviços. 
As Regiões Sudestes (com índices acima da média nacional) e Nordeste (com índices abaixo da média nacional) foram as que mais receberam recursos do BNH para saneamento. Segue a situação dos investimentos por Região antes da elaboração da PNDU.

Gráfico 13 - Investimentos do PLANASA por região, no período de 1968-1974

INVESTIMENTOS DO PLANASA POR REGIÃO, NO PERÍODO 1968-1974

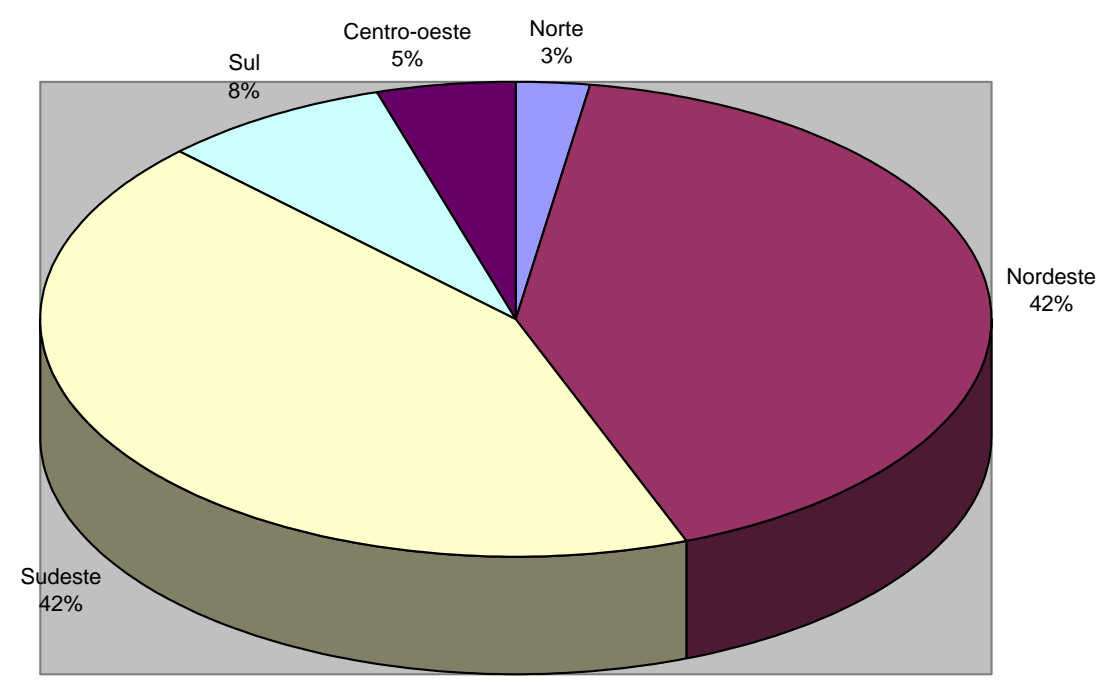

Fonte: BNH (Ministério do Interior, 1975)

O ambiente político marcado pela ditadura militar determinou o perfil da gestão do setor: centralização decisória; prestação de serviços subordinada à autosustentação tarifária, predominância das ações nas regiões mais desenvolvidas (Sudeste), aplicação dos subsídios cruzados e obrigatoriedade de concessão com as Companhias Estaduais de Saneamento Básico, renunciando a suas prerrogativas de poder concedente notadamente em matéria de políticas tarifárias de novos investimentos. 
Tabela 8 - Evolução da população coberta pelo Planasa em termos de abastecimento de água, segundo regiões (19701991) - (em milhares)

\begin{tabular}{|c|c|c|c|c|c|c|}
\hline \multicolumn{7}{|c|}{ ABASTECIMENTO DE ÁGUA - POPULAÇĀO ATENDIDA PELO PLANASA } \\
\hline \multicolumn{7}{|c|}{$\begin{array}{l}\text { Evolução da população coberta pelo PLANASA em termos de abastecimento de água, segundo regiões } \\
\qquad(1970-1991) \text { - (em milhares) }\end{array}$} \\
\hline Ano & Norte & Nordeste & Sudeste & Sul & Centro-Oeste & Brasil \\
\hline 1970 & 455,6 & 2582,2 & 7238,8 & 1289,3 & 314,7 & 11880,8 \\
\hline 1971 & 476,6 & 3097,2 & 8170,2 & 1530,3 & 335,9 & $13.610,30$ \\
\hline 1972 & 499,1 & 3805,3 & 8522,1 & 2259,6 & 354,5 & 15440,7 \\
\hline 1973 & 544,6 & 4409,6 & 9708,4 & 2702,2 & 477,9 & 17842,8 \\
\hline 1974 & 604,8 & 5037 & 10206,6 & 3441,2 & 1206,8 & 20496,6 \\
\hline 1975 & 685,4 & 5680,1 & 10857,6 & 4162 & 1343,6 & 22728,8 \\
\hline 1976 & 938,9 & 6149,4 & 15699,9 & 4659,3 & 1630,1 & 29347,7 \\
\hline 1977 & 1081 & 7512,5 & 18818 & 5575,4 & 2044,9 & 35032,8 \\
\hline 1978 & 1171,1 & 8288,5 & 20782,1 & 6285,6 & 2260,6 & 38788 \\
\hline 1979 & 1541,9 & 9332,7 & 23909,5 & 6731,5 & 2558,6 & 44074,4 \\
\hline 1980 & 1836,7 & 10567 & 28632 & 7852,1 & 2969,8 & 49568,5 \\
\hline 1981 & 1909,5 & 10567 & 28632 & 8500,1 & 3347,7 & 52308,5 \\
\hline 1982 & 2112,4 & 11494,5 & 30389,6 & 8500,1 & 3596,6 & 56093,3 \\
\hline 1983 & 2438,3 & 12853,1 & 31229 & 9297,9 & 4028,5 & 59847,1 \\
\hline 1984 & 2647,6 & 13831,7 & 32755 & 9801,9 & 4380,1 & 63416,4 \\
\hline 1985 & 2833,6 & 14862,9 & 34600,6 & 10411,3 & 4822,5 & 67531 \\
\hline 1986 & 3029,8 & 16214,4 & 33738,6 & 11070,1 & 5299,1 & 69352,2 \\
\hline 1987 & 3262,4 & 17178,5 & 35849,4 & 11676 & 5651,4 & 73617,9 \\
\hline 1988 & 3532,6 & 18202,8 & 38124,2 & 12642,2 & 5933,2 & 78434,2 \\
\hline 1989 & 3818,8 & 20539,1 & 36901,9 & 13728,9 & 6296,8 & 81285,7 \\
\hline 1990 & 4116,6 & 21122,8 & 37737,6 & 13535,6 & 6392,8 & 82905,6 \\
\hline 1991 & 4197,4 & 20823,1 & 37165,2 & 14185,8 & 6102,4 & 82474,2 \\
\hline
\end{tabular}

Fonte: CEF/DESAN, SOUZA (1990)

Gráfico 14 - Abastecimento de Água - População atendida pelo Planasa

Abastecimento de Água - População Atendida pelo Planasa

Evolução da população coberta pelo Planasa em termos de abastecimento de água, segundo regiões (1970-1991) - (em milhares)

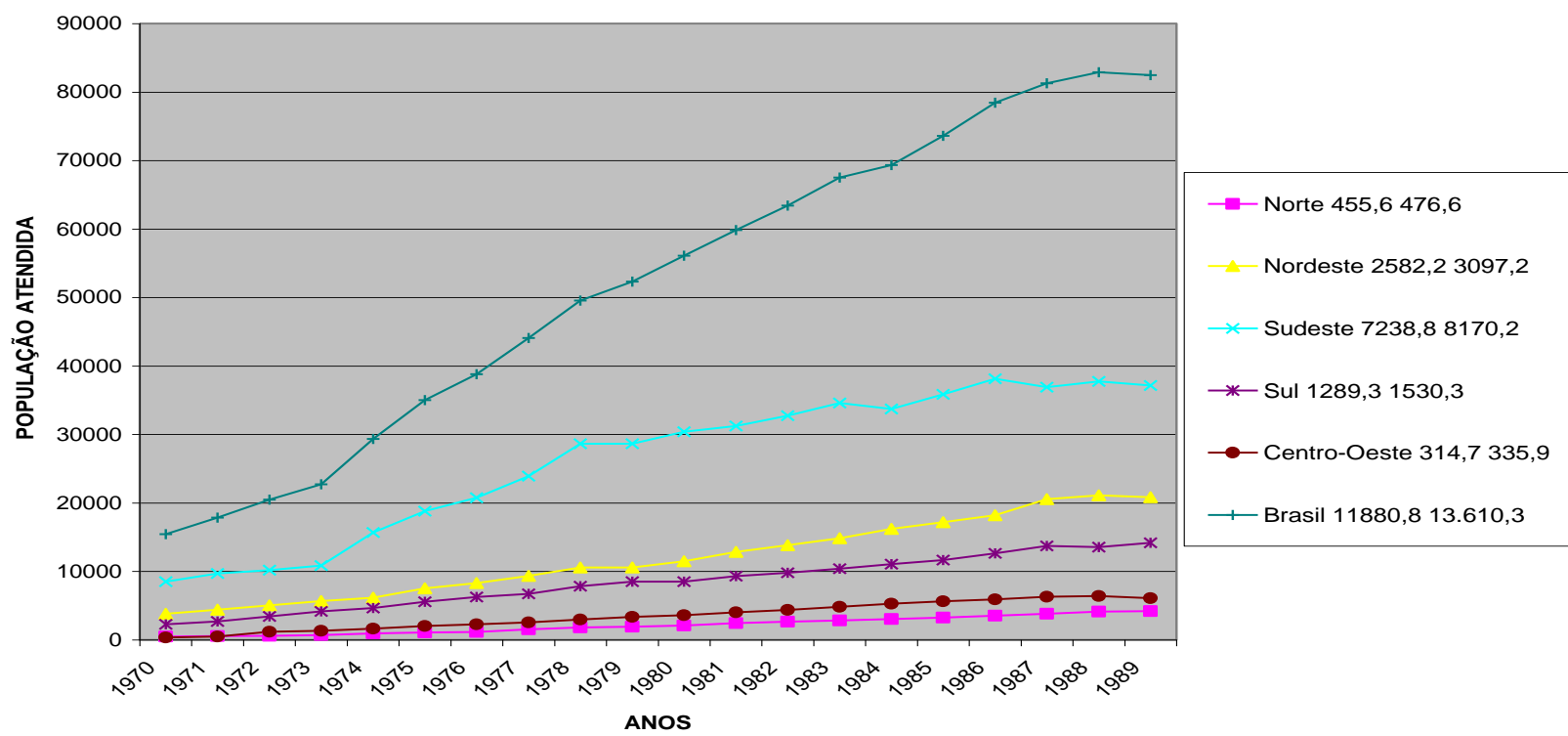

Fonte: Idem Tabela 8 (elaborado pela autora). 
Tabela 9 - Evolução da população coberta pelo Planasa em termos de esgotamento sanitário, segundo regiões (1970-1991) - (em milhares)

\begin{tabular}{|c|c|c|c|c|c|c|}
\hline \multicolumn{7}{|c|}{ ESGOTAMENTO SANITÁRIO - POPULAÇĀO COBERTA PELO PLANASA } \\
\hline Anos & Norte & Nordeste & Sudeste & Sul & Centro-Oeste & Brasil \\
\hline 1970 & 455,6 & 2582,2 & 7238,8 & 1289,3 & 314,7 & 11880,8 \\
\hline 1971 & 476,6 & 3097,2 & 8170,2 & 1530,3 & 335,9 & $13.610,30$ \\
\hline 1972 & 499,1 & 3805,3 & 8522,1 & 2259,6 & 354,5 & 15440,7 \\
\hline 1973 & 544,6 & 4409,6 & 9708,4 & 2702,2 & 477,9 & 17842,8 \\
\hline 1974 & 604,8 & 5037 & 10206,6 & 3441,2 & 1206,8 & 20496,6 \\
\hline 1975 & 685,4 & 5680,1 & 10857,6 & 4162 & 1343,6 & 22728,8 \\
\hline 1976 & 938,9 & 6149,4 & 15699,9 & 4659,3 & 1630,1 & 29347,7 \\
\hline 1977 & 1081 & 7512,5 & 18818 & 5575,4 & 2044,9 & 35032,8 \\
\hline 1978 & 1171,1 & 8288,5 & 20782,1 & 6285,6 & 2260,6 & 38788 \\
\hline 1979 & 1541,9 & 9332,7 & 23909,5 & 6731,5 & 2558,6 & 44074,4 \\
\hline 1980 & 1836,7 & 10567 & 28632 & 7852,1 & 2969,8 & 49568,5 \\
\hline 1981 & 1909,5 & 10567 & 28632 & 8500,1 & 3347,7 & 52308,5 \\
\hline 1982 & 2112,4 & 11494,5 & 30389,6 & 8500,1 & 3596,6 & 56093,3 \\
\hline 1983 & 2438,3 & 12853,1 & 31229 & 9297,9 & 4028,5 & 59847,1 \\
\hline 1984 & 2647,6 & 13831,7 & 32755 & 9801,9 & 4380,1 & 63416,4 \\
\hline 1985 & 2833,6 & 14862,9 & 34600,6 & 10411,3 & 4822,5 & 67531 \\
\hline 1986 & 3029,8 & 16214,4 & 33738,6 & 11070,1 & 5299,1 & 69352,2 \\
\hline 1987 & 3262,4 & 17178,5 & 35849,4 & 11676 & 5651,4 & 73617,9 \\
\hline 1988 & 3532,6 & 18202,8 & 38124,2 & 12642,2 & 5933,2 & 78434,2 \\
\hline 1989 & 3818,8 & 20539,1 & 36901,9 & 13728,9 & 6296,8 & 81285,7 \\
\hline 1990 & 4116,6 & 21122,8 & 37737,6 & 13535,6 & 6392,8 & 82905,6 \\
\hline 1991 & 4197,4 & 20823,1 & 37165,2 & 14185,8 & 6102,4 & 82474,2 \\
\hline
\end{tabular}

Fonte: CEF/DESAN, dados extraídos do trabalho de SOUZA,(1990). 
Gráfico 15 - Evolução da População Coberta pelo PLANASA em termos de esgotamento sanitário, segundo regiões, de 1970 a 1991)

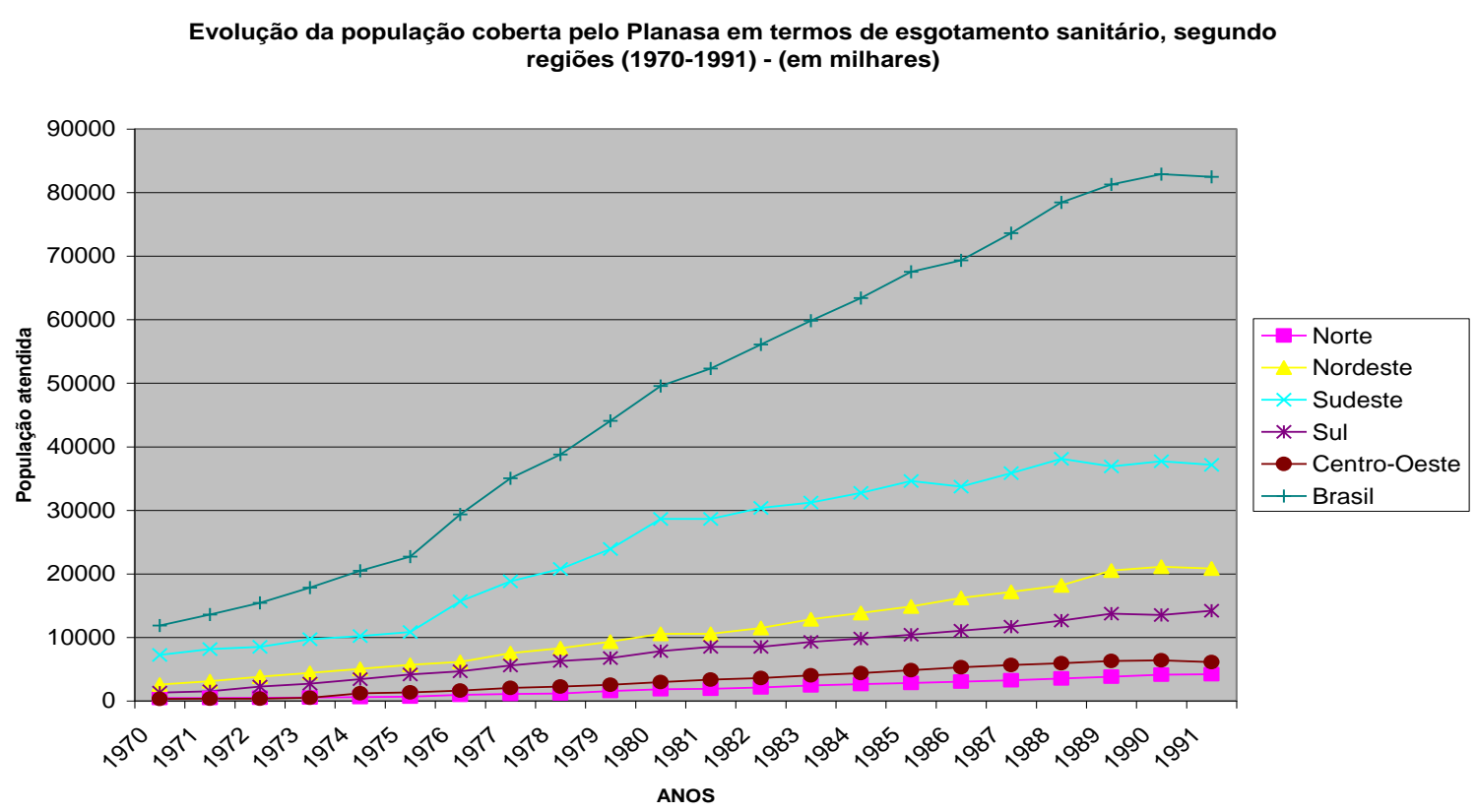

Fonte: Idem Tabela 9 (elaborado pela autora)

Em termos de resultados alcançados, pode-se dizer que o PLANASA conseguiu atingir a meta proposta e ampliar consideravelmente a cobertura de abastecimento de água e o de esgotamento sanitário em termos nacionais, concentrando-se também sobre a região de maior contingente populacional, a região Sudeste, mas também marginalizando parte da população sem condições de remuneração dos serviços (MINISTÉRIO DAS CIDADES, 2004c)

Em termos financeiros, um grande volume de recursos do FGTS foi investido no setor, o que acabou por descapitalizar o Fundo para outras áreas, até que com a crise destrutura-se a engenharia institucional e financeira para continuação do Plano. Em termos políticos, manteve-se a ideologia centralização de decisões pelo governo federal, principalmente em relação ao municípios, mas em relação aos Estados, manteve certo grau de descentralização dos serviços desse setor, que foram delegados às Companhias Estaduais.

\subsubsection{PNCCPM (Programa Nacional de Capitais e Cidades de Porte Médio)}

Steinberger e Bruna (2001) apontam que um estudo elaborado por Francisconi e Souza (1976) no período da PNDU, apontava a importância das cidades médias como 
estratégias de desconcentração e interiorização do sistema urbano, pelo saturamento dos núcleos principais, e dinamização das cidades de porte médio, com potencial de desenvolvimento industrial, ou como suporte para os serviços relacionados. Sobre as cidades de porte médio, esse documento apontava:

(...) eram as áreas estrategicamente mais importantes na rede urbana e aptas a receberem impulsos por serem os verdadeiros pólos de desenvolvimento. Dentre as cidades que já apresentavam potencial para desempenhar esse papel estavam as capitais estaduais e as metrópoles regionais interiorizadas. Estavam representadas em dois grupos: as áreas mais urbanizadas da região Sudeste, em fase de organização, sensíveis a inovações e com base socioeconômica sólida, em especial as situadas na franja de descentralização espontânea das metrópoles nacionais que tinham o papel de barrar o crescimento dessas, razão pela qual teriam condições de apresentar resposta rápida e eficiente; as metrópoles regionais interiorizadas nordestinas e as cidades médias do Centro-Oeste e Sul do País (50 mil a 250 mil habitantes), que além de desempenharem um papel estruturador da rede urbana, poderiam ser pontos de apoio da rede, servindo à economia agrícola e agroindustrial. (op. cit., p. 69-70, citado por STEINBERGER E BRUNA, 2001).

A interiorização ou proposta de composição de núcleos urbanos culminou na criação do Programa de Cidades Médias, em 1976, que se delongou por 10 anos de implementação sob o comando da CNPU e do Banco Mundial, com intenção de impactos sobre a desconcentração e dinamização do sistema urbano nacional.

O Programa Nacional de Capitais e Cidades de Porte Médio (PNCCPM) tinha por objetivo propiciar a criação de novos pólos de desenvolvimento, desconcentrar a população e as atividades e reduzir as disparidades de renda entre os municípios. Os pressupostos do programa baseavam-se na correlação entre aglomeração e desenvolvimento, e na possibilidade de concentrar investimentos em determinados pontos do espaço (Serra, 1991, p. 88).

Além disso, eram objetivos ainda do plano criar novas oportunidades de emprego e de contribuir para a redução das disparidades inter-regionais e da concentração da renda. Piquet e Ribeiro (2008) acreditam que a preocupação com a intensidade do crescimento demográfico das metrópoles nacionais - que absorviam grande parte do contingente populacional com origem nas zonas rurais das diversas regiões do país - levou à proposição de uma nova função para as cidades de porte médio: a de "dique" dos fluxos migratórios.

Assim, afirma Serra (1991), poder-se-ia melhor aproveitar o potencial representado pelas aglomerações de porte médio existentes no território nacional 
para, por meio dos investimentos no programa e de outros por ele induzidos, criar um pólo de desenvolvimento que passasse a atrair para si as atividades econômicas, emprego e população. Dada a realidade regional em diferentes patamares de desenvolvimento, concentrando grandes aglomerados em torno das regiões metropolitanas do Rio De Janeiro e de São Paulo, o investimento em subcentros próximos tinha a função de desconcentrar esse afogado urbano, para que outras regiões com potenciais de desenvolvimento ainda menos explorados, constituíssem centros com a função de dinamização da economia regional.

O escopo desse programa foi assim sistematizado por Serra:

\section{PROGRAMA NACIONAL DE CAPITAIS E CIDADES DE PORTE MÉDIO - PNCCPM} OBJETIVOS

- Propiciar novos pólos de desenvolvimento

- Desconcentração da população e das atividades econômicas

- Criar novos empregos

- Reduzir disparidades de renda

\section{PRESSUPOSTOS}

- Existência de relações entre a aglomeração e o desenvolvimento

- Possibilidade de concentrar os investimentos governamentais;

MÉTODO

- Concentrar ações do governo

- Atingir certos níveis de infra-estrutura urbana

- Atingir determinada escala de aglomerações

\section{CLASSIFICAÇÃO DOS CENTROS}

- Centros com função de desconcentração (alternativas para o Rio e São Paulo)

- Centros com função de dinamização (nas regiões que se pretende desenvolver)

Fonte: Serra, 1991.

Os critérios para seleção das cidades a serem contempladas pelo Programa passavam por questões espaciais e de aspectos intra-urbanos. Nos critérios espaciais, levava-se em conta a relevância regional, a localização em relação aos eixos principais, a existência de programas especiais na área, distância de outras aglomerações ou centros, posição estratégica. Nos aspectos intra-urbanos, as dimensões demográficas, o desempenho econômico, a grande proporção de migrantes recentes, a estrutura da PEA (População Economicamente Ativa), a pobreza urbana e a evolução urbana recente eram os critérios utilizados para selecionar os municípios que receberiam investimentos do Programa em cada região (SERRA, 1991). 
De 1976 a 1982, previu-se a implementação do Programa em cerca de 194 municípios, menos de $5 \%$ do total dos municípios existentes na época, e contraditoriamente ao discurso de desconcentração regional e dinamização de outras regiões da PNDU, os recursos investidos pelo Programa e quase a metade dos municípios contemplados estavam "concentrados" na região Sudeste, conforme podese constatar na Tabela 10 e no Gráfico 15.

Tabela 10 - Aplicações PNCCPM - 1976 a 1982 - por regiões (previsão)

\begin{tabular}{|l|c|c|r|c|}
\hline \multicolumn{5}{|c|}{ Aplicações PNCCPM - 1976 a 1982 - por regiões (previsão) } \\
\hline Regiões & Municípios & $\%$ (sobre o total) & OTNS & $\%$ (sobre o total) \\
\hline Norte & 13 & $7,1 \%$ & $862618,00 \$$ & $0,9 \%$ \\
\hline Nordeste & 44 & $23,9 \%$ & $3202994,00 \$$ & $3,4 \%$ \\
\hline Centro-oeste & 16 & $8,7 \%$ & $7835280,00 \$$ & $8,4 \%$ \\
\hline Sudeste & 86 & $46,7 \%$ & $42916422,00 \$$ & $46,2 \%$ \\
\hline Sul & 35 & $19,0 \%$ & $9279415,00 \$$ & $10,0 \%$ \\
\hline Total & 184 & $100,0 \%$ & $92923029,00 \$$ & $100,0 \%$ \\
\hline
\end{tabular}

Fonte: Avaliação do Programa de Nacional de Capitais e Cidades de Porte Médio,

FAU-USP - 1984 (Serra, 1991, p. 93)

Gráfico 16 - Relação entre a quantidade de municípios de médio porte e recursos destinados ao PNCCPM

RELAÇÃO ENTRE A QUANTIDADE DE MUNICÍPIOS (Selecionados por região/Total de selecionados) E RECURSOS DESTINADOS POR REGIÃO (Investimentos previstos por Região)

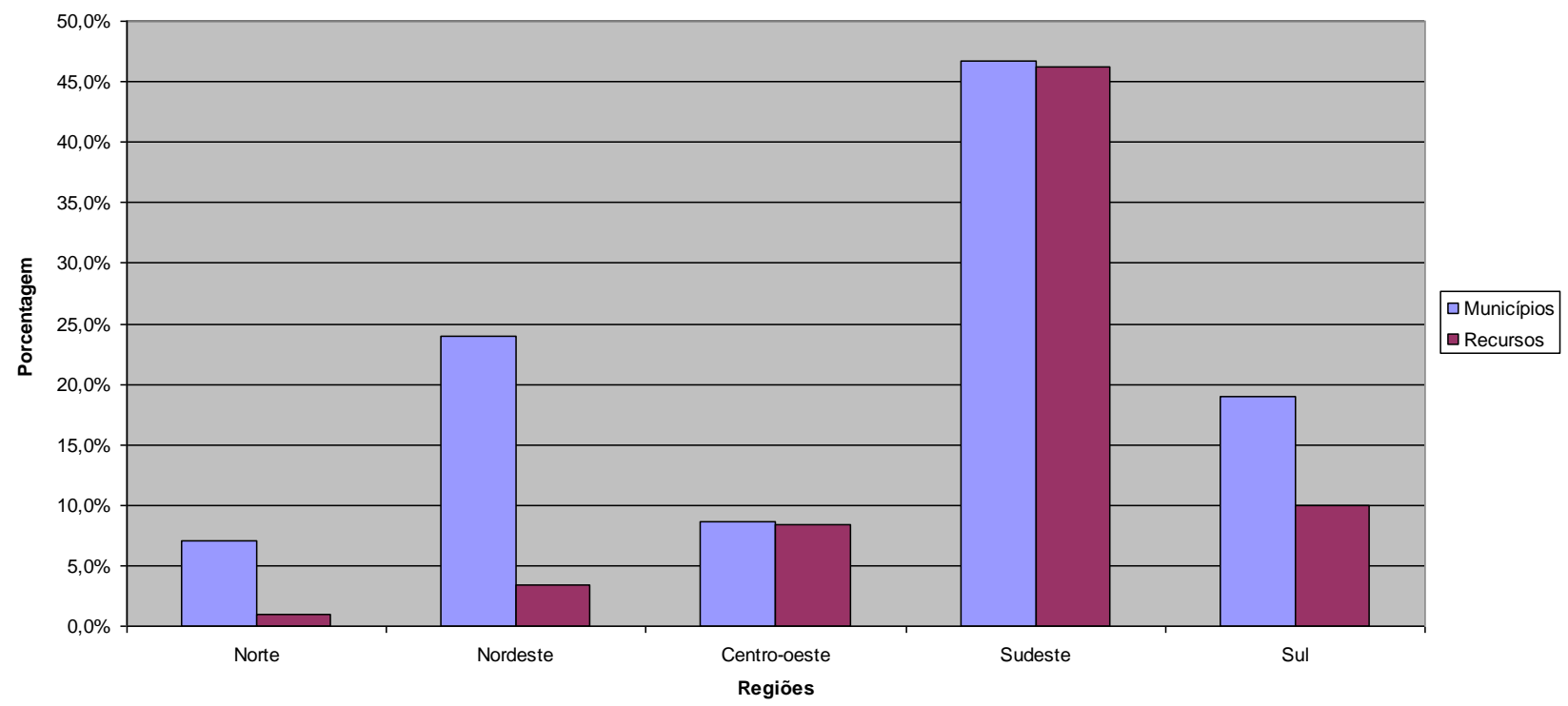

Fonte: Idem Tabela 10 (elaborado pela autora).

Uma das principais contradições entre o Programa e a PNDU está nos fatores de localização dos investimentos do Programa, que deveriam ser indicados pela PNDU, mas que de fato a Política não tinha força para determiná-los, senão "os 
critérios técnicos e econômicos usuais na localização industrial, afetados por alguns condicionantes políticos" (Serra, 1991, p. 91).

As ações seriam coordenadas pela CNPU, que no fim acabou por predominar sobre a articulação com os órgãos estaduais e federais, a intermediação da liberação de recursos estatais e privados. Porém, muitas dessas intervenções decididas a distância resultaram inócuas e sem continuidade, dado o distanciamento não só físico, mas político, social, financeiro do federal para o municipal. É mais um fator a se considerar em como a política federal pode dialogar e se articular de forma eficiente com as políticas e necessidades locais ou regionais.

Sobre a avaliação do Programa, Steinberger e Bruna (2001), afirmam que:

\begin{abstract}
"Uma questão paralela seria investigar se essa configuração teve como elementos desencadeadores as propostas de política urbana nacional e do Programa de Cidades de Porte Médio. Alguns planejadores, os mais otimistas, responderiam afirmativamente, enquanto outros diriam que as cidades de porte médio aconteceram a despeito dessas propostas. De fato, essa questão carrega um equívoco, pois a relação entre um programa e seus resultados não se restringe a uma medição direta de causa/efeito. Um conjunto de condições estruturais e conjunturais, dentre as quais a própria existência das políticas urbanas e o tempo decorrido, possibilitou que as cidades de porte médio se tornassem uma realidade. (op. cit, p. 32).
\end{abstract}

As autoras vêem resultados positivos na implementação do Programa, quando observa-se a configuração da rede urbana no final da década de 90 , isso pelos impactos qualitativos que a ação do programa teve em relação aos objetivos pretendidos, "dado que houve uma substancial desconcentração, via cidades de porte médio, bases da estratégia da política urbana nacional adotada pelo Estado nos anos 70." Quanto a fatores interferentes nos resultados, os internos estão relacionados à concepção e à consistência do programa e da política urbana, e os externos a questões conjunturais e/ou estruturais, que escaparam ao controle dos gestores do programa. (op. cit. p. 36).

Já o grupo do Ministério das Cidades (2004a, p. 34) avalia que, "seguindo uma lógica centralista, o Programa de Cidades de Porte Médio promoveu a difusão dos investimentos urbanísticos em pequenas capitais e pólos regionais sem guardar relação com os incentivos fiscais para projetos industriais e agropecuários que eram 
concedidos por superintendências regionais como a SUDENE", mostrando a desarticulação interna dentro do próprio governo em suas ações, mesmo com a excessiva descentralização.

\subsubsection{Plano de Complementação Urbana - Projetos CURA}

O Plano de Complementação Urbana inseria-se dentro dos Programas de Urbanização e equipamentos comunitários do BNH que, tendo em vista a carência de equipamentos sociais na maioria das cidades, principalmente nas zonas periféricas das manchas urbanas, pretendia prover essas áreas com "melhorias urbanas" em alguns setores. A implementação do Plano se daria por meio dos Projetos CURA (Comunidade Urbana de Renovação Acelerada), a serem implementados em áreas pré-determinadas pelo governo.

A expectativa do Ministério do Interior era de que esses "mecanismos", os Projeto CURA, seriam poderosos "agentes de racionalização do espaço urbano". A regulamentação do Plano demandava medidas pedagógicas consideradas essenciais para planejamento-urbano, uma vez que se constituíam em pré-requisitos para aprovação e obtenção de financiamento para os projetos (MINISTÉRIO DO INTERIOR, 1975, p. 64):

- Instituição de IPTU progressivo nas áreas CURA;

- Fixação de taxas mínimas e máximas nas áreas de ocupação do projeto;

- Elaboração de estudo de viabilidade do projeto;

- Legislação para aprovação de novos loteamentos e parcelamentos de terra;

O quadro urbano que justificava o lançamento desse Programa era já conhecido (crescimento desordenado, carência de infra-estrutura e equipamentos etc), mas um em especial justificava intervenções tão "pontuais" no espaço intra-urbano, que era a "especulação pela retenção de glebas e lotes", os vazios urbanos, que faziam da cidade uma sobreposição de loteamentos sucessivos, como relata Serra (1991), ou de baixo padrão técnico, principalmente quanto às redes de infra-estrutura, ou de terrenos intencionalmente deixados desocupados, aguardando os investimentos públicos ou privados para melhoria do entorno, e então, valorização financeira desses espaços na cidade.

O CURA era destinado, originalmente, à complementação da infra-estrutura em áreas de "vazios urbanos". Dever-se-ia executar obras não só de infra-estrutura, mas 
de equipamentos comunitários para eliminar a capacidade ociosa, assim como reduzir a especulação e racionalizar investimentos nas cidades. Serra chama a atenção para o que era a tese principal do governo federal, ou seja, a ideologia do centralismo, que demandava "o estabelecimento de critérios objetivos para a fixação das prioridades em níveis tecnicamente satisfatórios". Isso se traduzia por adequar os critérios aceitáveis de escolha das áreas e dos tipos de projetos segundo as decisões da tecnocracia federal.

O centralismo se concretizava ainda nos trâmites criados para liberação dos recursos, que eram oriundos do FGTS e contavam também com parceria do BIRD: "o governo federal apropriava-se de parte da receita dos municípios, ao mesmo tempo que aumentava a demanda por investimentos em urbanização, promovendo uma urbanização acelerada e, finalmente, empresta ao Município o dinheiro do trabalhador, com juros e correção monetária, empréstimo esse subordinado ao controle técnico e político do governo federal (SERRA, 1991). Apesar dessa ideologia tecnocrática e centralizadora, o Programa parece ter sofrido modificações de seu escopo original ao longo do tempo, o que parece ter sido benéfico para a obtenção de melhores resultados onde foram implementados.

As áreas para investimento e os resultados dessas intervenções eram: sistema viário (movimento de terra, guias, sarjetas, pavimentação, sinalização, arborização), drenagem (associada ao sistema viário e à canalização de córregos), educação e cultura (creches, por exemplo), serviço social, recreação e lazer, iluminação pública, transportes urbanos (abrigos de pontos de ônibus), saúde, abastecimento de água, coleta de esgotos, comércio e abastecimento, desapropriações, estudos e projetos, gerenciamento. Numa análise por amostragem de cidades feita por Serra (1991), que categorizou a distribuição de recursos por esses setores, concluiu-se que o principal destinos dos recursos era para o sistema viário, seguido da drenagem (provavelmente por custos associados), e em seguida equipamentos de recreação e lazer.

Durante 12 anos, 136 municípios foram atendidos pelo CURA, que financiou projetos integrados de obras urbanas com "melhora da qualidade das condições ambientais de vida nas áreas em que atuou", segundo Fest (2005). Para chegar a essa conclusão sobre o CURA, esse pesquisador baseou-se no caso de Lavras/MG, onde relata que o Plano de Complementação Urbana para a cidade: 
"evidenciou a capacidade transformadora do programa, que ofereceu o indispensável suporte para a alteração da estrutura urbana tradicional da cidade. A partir da ação do CURA o tecido urbano se adensou e se expandiu, a infra-estrutura melhorou, a superestrutura passou a incluir equipamentos intra-urbanos de porte, alguns a escala microrregional, um distrito industrial foi instalado. O IDH cresceu de 0,482 em 1970 para 0,819 no ano $2.000 "$.

Na cidade de São Paulo, obras de "reurbanização" realizadas pela Prefeitura na década de 70, foram realizada com recursos do BNH dentro do Projeto CURA, como foi o caso do complexo empresarial do Itaú, na região do metrô Conceição, área essa objeto de desapropriações e reparcelamentos do solo com intuito de "desafogar" as áreas centrais por meio da verticalização e liberação de espaço para circulação e áreas verdes. Diferentemente dos outros contextos, as obras do CURA em São Paulo tinham a intermediação da EMURB (Empresa Municipal de Urbanização) (LUCCHESE, 2004). Esse pode ser um exemplo da "apropriação privada" dos investimentos públicos, com a idéia das "contribuições de melhoria" como contrapartidas privadas.

Em muitos casos, como o apresentado de Lavras $^{89}$, ou mesmo os resultados do Programa renderam melhorias significativas. Porém, um dos aspectos a serem observados na escolha das áreas de intervenção, as chamadas áreas CURA, era que contraditoriamente, em vez de combater a especulação, poderia fomentá-la, como foi o caso de São Paulo, ampliando a concentração de "terra urbanizada" e a criação de espaços-mercadoria na cidade, em lugar de democratizar o acesso à infra-estrutura e equipamentos pela maioria de seus habitantes.

O relatório avaliativo elaborado pelo CEPAM (Fundação Prefeito Faria Lima) sobre os resultados do Projeto CURA aponta também resultados nessa direção:

- "Quando o nível geral da cidade é bom, o Projeto CURA tende a "preencher lacunas e a equalizar (sic) a distribuição de equipamentos pelos diferentes setores da cidade"

- Caso contrário, o CURA tenderia a formar ilhas de padrão mais elevado;

- O CURA tanto pode "amenizar como exacerbar desigualdades na distribuição de equipamentos urbanos e pode ser usado para atendera segmentos da população dos mais diversos níveis de renda" (CEPAM, 1976, citado por SERRA, 1991, p. 115)

Por fim, pode-se dizer que o Plano de Complementação Urbana, que deu origem aos Projetos CURA em várias cidades brasileira, no aspecto econômica,

\footnotetext{
${ }^{89}$ A avaliação dos impactos do Projeto CURA em outras cidades pode também ser encontrado em Serra (1991).
} 
cumpriu seu papel de dinamizar a economia da cidades em termos de obras e emprego na construção civil; no aspecto de intra-urbano, da "complementação urbana", viabilizou, embora restritamente, reestruturações, complementação de infra-estrutura, localização de equipamentos urbanos etc; embora de certa forma, clientelista, na medida que os critérios para escolha das áreas de intervenção permitiam distorções no beneficiamento de áreas privilegiadas. Do ponto de vista das relações intergovernamentais, ficaram marcadas pela concepção centralista autoritária, nos aspectos políticos, técnicos e financeiros; no âmbito do físico-territorial, viu-se uma atomização do planejamento, na medida em que a cidade era fragmentada em diversos projetos urbanos isolados e por vezes sem continuidade nem integração em um planejamento urbano continuado.

\subsubsection{Os Planos de Desenvolvimento Local Integrado}

Como já bem discutido em itens anteriores, a noção de planejamento urbano no contexto da PNDU de 1975, em sua concepção metodológica, era marcado pela concepção de planejadores técnicos dentro dos órgãos de planejamento governamentais, concentrados principalmente no SERFHAU.

A idéia de Planos Diretores municipais começou a ter mais ênfase e "apoio" governamental a partir da década de 1960, quando o SERFHAU foi criado dentro do Ministério do Interior e Coordenação, "e se encarregava de estudar os problemas do desenvolvimento urbano no quadro geral do processo de desenvolvimento econômico e social do País (MINISTÉRIO DO INTERIOR, 1975, p. 9).

Num contexto anterior ainda à criação da PNDU, em 1969, o Ministério do Interior criou o PAC - Programa de Ação Concentrada que, já dentro da idéia de criação de um política de desenvolvimento do País, previa a elaboração de estudos sobre a realidade das cidades a serem realizados em 457 centro urbanos, com nível de abrangência conforme o tamanho dos municípios, podendo variar desde simples Relatórios Preliminares (RP), para os municípios pequenos, aos Planos de Desenvolvimento Local Integrado (PDLIS) (Monte-Mór, 2008, p. 51).

Com a criação do FGTS e ampliação do montante de recursos à disposição do BNH para financiar o desenvolvimento urbano "o BNH adotou medidas no sentido de conceder os financiamentos para a área urbana mediante a apresentação, pelos 
interessados, de planos de desenvolvimento local integrado que constituíam, no seu entender, instrumentos úteis ao julgamento das aplicações do sistema financeiro da habitação.

Para subsidiar esse processo, na ocasião também foi instituído o FIPLAN (Fundo de Financiamento de Planos de Desenvolvimento Local Integrado) "com o objetivo de prover os recursos necessários à elaboração de planos, programas e projetos de desenvolvimento urbano e local". E para completar, foi instituído o Sistema Nacional de Planejamento Local Integrado, e SERFHAU ficou como órgão central do Sistema: "o SERFHAU, assim fortalecido, pôde dar início à tarefa de conduzir o planejamento urbano e local do País".

Viu-se uma grande movimentação financeira e institucional para apoiar o planejamento urbano local, promovido pelo governo federal, isso porque era de interesse do governo a centralização e controle sobre esse planejamento, de forma a garantir suas prioridades e dos "clientes" do governo na estruturação das cidades. Devido a essa imposição de elaboração dos planos para obtenção de recursos, além de terem que se submeter à burocracia governamental criada, os planos eram por vezes feitos a toque de caixa, por equipes técnicas terceirizadas, ressalvadas, claro, algumas experiências que foram proveitosas para cidades que ainda não dispunham de diagnóstico sobre sua situação urbana (SERRA, 1991)

Serra (1991, p. 131) afirma ainda que "a política nacional de desenvolvimento urbano, contida no II PND, continuou a utilizar os conceitos de concentração de investimentos em pontos estratégicos do espaço e de controle da administração municipal”. Em muitos dos planos, as decisões e recursos estavam amarradas às diretrizes centrais para sua elaboração e implementação, do que dependiam também outros projetos, como os CURA (Comunidade Urbana para Renovação Acelerada), que deveriam obedecer à imposição do modelo do BNH para o plano.

"Foram justamente essas pretensas superioridade e neutralidade da técnica que levaram o planejamento a um isolamento em relação à população, e a ausência desses mesmos resultados terminou por transformar o Plano Diretor em um texto burocrático, cujo interesse político, principalmente num momento histórico em que inexistia o controle social sobre essas atividades, restringia-se aos aspectos que poderiam alterar o valor da terra e atender interesses de investidores." (NUNES, 2009). 
Para Monte-Mór (2008) a tentativa de implementação do planejamento "integral" preconizado pelo SERFHAU, abrangendo "visão físico-territorial, social, econômica e administrativa, se por um lado abria uma nova dimensão à tentativa de organização do espaço urbano," tomando como base o município como entidade autônoma, esbarrava na centralidade crescente do governo federal, e mantinha uma visão política inconsistente com o planejamento econômico central.

Essa incompatibilidade de visão do SERFHAU com a visão político-econômica dos planejadores econômicos do governo, e o baixo nível de autonomia dos municípios, fadou a tentativa de promoção do planejamento e desenvolvimento municipal a "mera figura de retórica", nos dizeres de Monte-Mór, e o SREFHAU acabou integrado à centralização do BNH.

"Na verdade, o SNPLI - Sistema Nacional de Planejamento Local Integrado transformou-se, apenas, num promotor de documentos técnicos que tinha em última instância, o papel de modernizador das burocracias municipais" (op. cit. p, 52). As consultorias obedeciam à metodologia geral definida pelo SERFHAU/BNH, dentro da idéia do planejamento compreensivo, racional e positivista, baseados ainda num ideal de cidade distante da realidade dos municípios.

"Montou-se todo um discurso de planejamento urbano voltado para o fortalecimento da célula mínima autônoma da nação - o município quando os instrumentos da política eram cada vez mais centralizados e autoritários. De fato, entretanto, pretendeu-se o desenvolvimento local integrado atrelado aos grandes objetivos nacionais" (Monte-Mór, 2008, p. 53).

Uma avaliação do Ministério das Cidades sobre a trajetória dos Planos Diretores no Brasil apresenta, em síntese, os seguintes traços predominantes (MINISTÉRIO DAS CIDADES, 2004b):

- Visão tecnocrática no processo de elaboração;

- Terceirização por consultorias ou especialistas;

- Baixa integração dos quadros técnicos, bem com das diversas secretarias municipais;

- Quadros técnicos insuficientes e incapazes de dar seguimento à implementação do plano diretor elaborado;

- Ausência de participação popular, mas interlocução com setores imobiliários;

- Participação consultiva de validação de diagnósticos em audiências públicas formais; 
- Planos normativos, com concepções idealizadas de cidades pelos técnicos, sem incorporar os conflitos dos atores nos territórios.

O tipo de planejamento urbano assim praticado, reforçado durante a PNDU e continuado em períodos posteriores, tem sido tomado por mudanças gradativas no compasso da democratização e descentralização nos últimos anos, que têm permitido novas perspectivas para os planos diretores municipais, pelo menos em termos de processo de elaboração e instrumentação para sua implementação.

\subsection{Planos, programas a ações da PNDU de 2004}

\subsubsection{Os Planos Diretores Participativos}

Na nova PNDU um dos eixos principais das políticas de planejamento e gestão municipais assenta-se justamente sobre os incentivos à elaboração ou revisão dos Planos Diretores para os municípios acima de 20 mil habitantes, para os quais a elaboração do Plano é obrigatória.

Devido ao legado do período tecnicista e burocrático em que foram concebidos planos diretores municipais a "toque de caixa" para recebimento de recursos do $\mathrm{BNH}$, como já visto anteriormente, o planejamento municipal ficou negativamente marcado pelo tradicionalismo na composição de diagnósticos, zoneamentos, taxa de ocupação etc, que apesar da marca racionalista, foram as ferramentas das quais se valeram as administrações para regular as investidas privadas sobre a ocupação do solo urbano.

Mas constatou-se ao logo dos anos que para um Plano Diretor atualizar-se conforme as mudanças da configuração das cidades, precisava-se muita mais do que ferramentas de cunho físico-territorial, mas sobretudo de cunho político, uma vez que o plano em si não teria impacto executivo para o "bem coletivo", se não dispusesse da participação da coletividade, da sociedade em seus diversos segmentos, e do comprometimento político dos diversos poderes executivo, legislativo e judiciário, nos vários níveis, não só no municipal, para sua implementação.

As mudanças ocorreram principalmente a partir instituição da competência municipal sobre o planejamento intra-urbano, por meio do Plano Diretor, primeiro no 
Capítulo constitucional sobre a Política Urbana ${ }^{90}$ e posteriormente com a aprovação do Estatuto da Cidade, que categoricamente explicita o Plano Diretor como o instrumento básico da política urbana e do planejamento municipal, contendo um Capítulo específico sobre os Planos Diretores, o Capítulo III, tendo como diretriz principal o cumprimento da "função social da propriedade urbana" e a "participação social" no processo de elaboração:

Art. 39. A propriedade urbana cumpre sua função social quando atende às exigências fundamentais de ordenação da cidade expressas no Plano Diretor, assegurando o atendimento das necessidades dos cidadãos quanto à qualidade de vida, à justiça social e ao desenvolvimento das atividades econômicas, respeitadas as diretrizes previstas no art. $2^{\circ}$ desta Lei.

Art. 40. O Plano Diretor, aprovado por lei municipal, é o instrumento básico da política de desenvolvimento e expansão urbana.

$\S 1^{\circ}$ O Plano Diretor é parte integrante do processo de planejamento municipal, devendo o plano plurianual, as diretrizes orçamentárias e o orçamento anual incorporar as diretrizes e as prioridades nele contidas.

$\S 2^{\circ}$ O Plano Diretor deverá englobar o território do Município como um todo.

$\S$ 3ํㅡ A lei que instituir o Plano Diretor deverá ser revista, pelo menos, a cada dez anos.

$\S 4^{\circ}$ No processo de elaboração do Plano Diretor e na fiscalização de sua implementação, os Poderes Legislativo e Executivo municipais garantirão:

I - a promoção de audiências públicas e debates com a participação da população e de associações, representativas dos vários segmentos da comunidade;

II - a publicidade quanto aos documentos e informações produzidos;

III - o acesso de qualquer interessado aos documentos e informações produzidos.

Art. 41. O Plano Diretor é obrigatório para cidades:

I - com mais de vinte mil habitantes;

II - integrantes de regiões metropolitanas e aglomerações urbanas;

III - onde o Poder Público municipal pretenda utilizar os instrumentos previstos no $\S 4^{\circ}$ do art. 182 da Constituição Federal;

IV - integrantes de áreas de especial interesse turístico;

$\mathrm{V}$ - inseridas na área de influência de empreendimentos ou atividades com significativo impacto ambiental de âmbito regional ou nacional.

$\S 1^{\circ}$ No caso da realização de empreendimentos ou atividades enquadrados no inciso $\mathrm{V}$ do caput, os recursos técnicos e financeiros para a elaboração do Plano Diretor estarão inseridos entre as medidas de compensação adotadas.

$\S 2^{\circ}$ No caso de cidades com mais de quinhentos mil habitantes, deverá ser elaborado um plano de transporte urbano integrado, compatível com o Plano Diretor ou nele inserido.

Art. 42. O Plano Diretor deverá conter no mínimo:

I - a delimitação das áreas urbanas onde poderá ser aplicado o parcelamento, edificação ou utilização compulsórios, considerando a existência de infra-estrutura e de demanda para utilização, na forma do art. 5ㅇs. desta Lei;

II - disposições requeridas pelos arts. 25, 28, 29, 32 e 35 desta Lei;

\footnotetext{
90 “Art 182 Parágrafo 1: O Plano Diretor, aprovado pela Câmara Municipal, obrigatório para cidades como mais de vinte mil habitantes, é o instrumento básico das políticas de desenvolvimento e expansão urbana". Cf. Constituição de 1988.
} 
III - sistema de acompanhamento e controle. (ESTATUTO DA CIDADE,, $2001)^{91}$.

Munidos dessas novas diretrizes e instrumentos, os Planos Diretores foram "regatados" da mesmice burocrática, tecnicista e pouco eficiente de outrora, para tentar enfrentar de forma mais "realista" as transformações que o espaço e seus agentes sofreram ao longo do tempo. Nesse intuito, de dar "nova cara" ao planejamento municipal é que foi a lançada uma ampla campanha, com mecanismos legais obrigatórios, para revisão dos textos dos planos diretores já existentes, ou de criação nas cidades que ainda não haviam elaborado seus PDPs, na expectativa de um processo, de fato, participativo, e que se pudesse implementar com mais facilidade os tão "caros" instrumentos do Estatuto para cumprimento da função social da cidade.

Dentro da Política Nacional de Estímulo à Revisão dos Planos Diretores, os números oficiais dão conta de uma experiência positiva de revisão iniciada e criação dos planos, a partir de 2004, com sistemáticas específicas a cada ano, que preconizaram o envolvimento dos diversos entes federados, poderes, segmentos sociais, sob o entendimento de um processo de cooperação e articulação para, compreensão dos conflitos, mas busca de consensos coletivos (algo quase impossível de se conseguir na prática) e de diretrizes e ações negociadas sobre as cidades.

Em contraste ao processo anterior de elaboração dos Planos Diretores, estes deixam de se tornar instrumentos meramente físicos, programáticos, racionalistas e positivistas, para abranger uma visão multidimensional da cidade, nas de diversas visões política, social, econômica, cultural e ambiental que se manifestam e se expressam sobre o território e dinamizam a ocupação do espaço e a sua transformação. Para isso foram propostos processos de leituras técnicas participativas da cidade, fóruns de discussão para elaboração de propostas, assembléias públicas, ou, seja, foram criados canais para uma participação mais efetiva dos diversos setores na elaboração ou revisão do Plano.

Há semelhanças e diferenças entre a visão que envolve os planos diretores nas duas PNDUs. Em ambas as políticas, os Planos Diretores são os instrumentos 
básicos do planejamento intra-urbano, e há o "estímulo" dos órgãos governamentais, claro, via condicionamento à liberação de recursos para que os municípios elaborassem seus planos. E permanece uma forte crítica sobre eficiência e eficácia desses planos em ambas as situações.

No início da década de 1960, em que pese ter sido marcante a ampliação da participação política, esta acabou por não se institucionalizar plenamente, justificando de certa forma o percurso que "teve como eixo as atividades e discursos que vieram a desembocar nos atuais planos diretores" (Villaça,1999, p. 175, citado por NUNES, 2009).

Tratando-se de um documento de escopo amplo, não só dos diversos segmentos da sociedade, mas também em termos institucionais e de recursos, pressupondo a cooperação interministerial, intersetorial, e interinstitucional para o alcance de seus objetivos e implementação de seus instrumentos, uma vez que há mais uma tradição "centrífuga", do que "centrípeta" nas relações inter e intragovernamentais, ou seja, mais de divergência de interesses ações isoladas do que convergência e trabalho conjunto na definição dos programas e implementação das ações.

Foi proposto um novo escopo na revisão e elaboração dos Planos Diretores que deveriam observar:

A) verificação da função social da propriedade e garantia de terras e
imóveis para os empreendimentos de interesse social; B) elaboração de
Plano de Reabilitação de Áreas Centrais para o financiamento da
Habitação de Interesse Social em regiões dotadas de infra-estrutura
urbana; C) ampliação do controle público sobre a ocupação do solo em
áreas de proteção ambiental e de risco geotécnico; D) impedimento para
a construção de novas moradias urbanas em áreas afastadas do tecido
urbano consolidado; E) regularização e urbanização de áreas de
assentamentos precários ou sua remoção para áreas contíguas, em
situações dignas; F) elaboração de planos setoriais de Habitação e
Saneamento Ambiental (MINISTÉRIO DAS CIDADES, 2004a, p.57)

Sem dúvida, as propostas, as iniciativas, o desejo e as intenções do grupo do Ministério da Cidade são relevantes, que permitem uma abordagem tão positiva quanto o entusiasmo do discurso cooperativo e participativo, mas que certamente, enfrentam realidades, contextos e práticas instaladas de décadas, nas políticas, no mercado, e na sociedade, que geram novos desafios a serem enfrentados na tentativa de que os planos diretores sejam, além de um instrumento da técnica, da política, ou do mercado, também um instrumento da democratização das cidades para o cumprimento de sua função social. 
Segundo RODRIGUES E BARBOSA (2010, p. 26) "a primeira batalha a ser travada foi, na maioria das cidades, exatamente a questão da participação da sociedade. Argumentos autoritários ou tecnocráticos questionavam a capacidade de a população participar da elaboração dos planos. A tradição de planos diretores feitos por especialistas, em geral por consultorias contratadas e sem nenhum diálogo com a cidade, ainda hoje, permeia as práticas de planejamento. Tampouco havia um consenso ou uma norma para avaliar o que $s$ podia ou não qualificar de "participativo". A edição da Resolução 25 do Conselho das Cidades, em março de 2005, deu melhor definição sobre o processo participativo, com orientações para a sua efetivação". ${ }^{2}$

Os mesmos autores levantam ainda a dificulta de leitura técnica dos Planos pela população. Nos processos participativos, a adequação da linguagem técnica tem que ser levada a um nível mínimo de compreensão por parte dos "leigos", sob pena de tornarem nulos os esforços de inclusão participativa na elaboração dos planos. E esse baixo de nível de compreensão não se limita à lideranças das associações de bairros ou dos movimentos populares, mas atinge também os legisladores, os vereadores que aprovam o Plano Diretor, que apresentam baixo conhecimento técnico, tornando questionável sua capacidade de avaliar adequadamente as proposições da Lei do Plano Diretor local.

\subsubsection{Plano Nacional de Habitação}

No contexto da nova PNDU, a questão habitacional assumiu uma importância ímpar, dadas as condições precárias de habitação que se agravaram nos anos 80 , juntamente com as crise econômica e urbana.

\footnotetext{
92 No entanto, os autores afirmam que "foram inúmeros os casos de conflitos nos municípios sobre o tema da participação. Por meio de pressões, manifestos e também demandas ao Ministério Público e ao Judiciário, os movimentos, articulados com outros segmentos, exigiram participar não só das audiências públicas, mas de todo o processo de elaboração. Foram batalhas que levaram meses e algumas delas conseguiram interromper ou alterar o processo, garantindo alguma reversão em favor da sociedade. Em diversas cidades, ações civis e representações no Ministério Público, Defensorias Públicas e mobilizações do povo nas Câmaras. Municipais e Prefeituras questionaram a forma de elaboração de planos diretores e também o seu conteúdo depois de aprovado (op. cit., p.26)
} 
O diagnóstico da questão habitacional apontado pelo Ministério das Cidades (2004b), aponta situações de déficit habitacional ${ }^{93}$ da ordem de 7,2 milhões de moradias, concentrados nas áreas urbanas, metropolitanas, e regionalmente, no Sudeste e Nordeste, que agregam as maiores densidades populacionais do Brasil. As menores faixas de renda, ate 2 salários mínimos são as que mais sofrem com as carências habitacionais

Tabela 11 - Domicílios particulares ocupados em 2004

Tabela 2864 - Domicílios particulares permanentes e Moradores em domicílios particulares permanentes, por tipo de domicílio e condição de ocupação

\begin{tabular}{|l|c|c|c|c|}
\hline \multicolumn{5}{|c|}{ Variável $\begin{array}{c}\text { Domicílios particulares permanentes (Percentual) } \\
\text { Tipo de domicílio = Total }\end{array}$} \\
\hline \multirow{5}{*}{ Brasil e Região Geográfica } & \multicolumn{5}{c|}{ Ano = 2004 } \\
\cline { 2 - 5 } & Próprio & Alugado & Cedido & Outra condição \\
\hline Brasil & 73,71 & 15,42 & 10,38 & 0,49 \\
\hline Norte & 77,6 & 11 & 10,59 & 0,81 \\
\hline Nordeste & 76,75 & 12,28 & 10,56 & 0,41 \\
\hline Sudeste & 71,67 & 17,82 & 10,04 & 0,47 \\
\hline Sul & 76,72 & 13,82 & 9 & 0,46 \\
\hline Centro-Oeste & 65,27 & 19,49 & 14,55 & 0,69 \\
\hline
\end{tabular}

Nota:

1 - Até 2003, exclusive a população da área rural de Rondônia, Acre, Amazonas, Roraima, Pará e Amapá.

2 - Exclusive os moradores cuja Condição no domicílio era pensionista, empregado doméstico ou parente de empregado doméstico.

3 - Os dados desta tabela foram reponderados pelo peso definido pela Contagem da População de 2007.

Fonte: IBGE - Pesquisa Nacional por Amostra de Domicílios

O Plano Nacional de Habitação, cuja discussão inicial se deu em agosto de 2007, constitui "etapa essencial de implantação e consolidação da Política Nacional de Habitação" " Com ele pretende-se orientar as ações e projetos e investimentos na área habitacional, dos setores público e privado, congregando os esforços com Estados e Municípios para superação do déficit habitacional.

Em 2005 foi criado o Sistema Nacional de Habitação de Interesse Social (SNHIS), centralizado todos os programas, ações e projetos de habitação social, bem como os conselhos, os gestores financeiros e parceiros da implementação das ações.

\footnotetext{
93 "O déficit habitacional é calculado com base em pesquisas domiciliares e refere-se a uma estimativa que caracteriza o estoque na data da pesquisa domiciliar. A caracterização do estoque realizada nesses trabalhos é aprofundada e cumpre com as necessidades de planejamento de políticas." In: Oliveira, Elzira Lúcia de. Demanda futura por moradias no Brasil 2003-2023: uma abordagem demográfica. Brasília: Ministério das Cidades, 2009

94 Fonte: Secretaria Nacional de Habitação - 22.02.2008 < http://www.cidades.gov.br/secretariasnacionais/secretaria-de-habitacao/planhab>
} 
Posteriormente, em 2006, foi criado o Fundo Nacional de Habitação de Interesse Social (FNHIS) concentrando os recursos orçamentários para assentamentos subnormais e habitação de interesse social. É composto principalmente de recurso do Orçamento Geral da união (OGU) e do Fundo de Assistência Social (FAS), com destinação definida em Lei.

Foi montado abaixo um quadro com uma síntese dos principais programas desenvolvidos no âmbito da Secretaria Nacional de Habitação, divididos por origem dos recursos (como apresentado no site desta secretaria) com seus objetivos principais, permitindo uma visualização do escopo de atuação dessa Secretaria nesses anos de criação do Ministério das Cidades.

Quadro 7 - Programas desenvolvidos pela Secretaria Nacional De Habitação na PNDU de 2004

\begin{tabular}{|c|c|}
\hline PROGRAMA / FUNDO & OBJETIVO PRINCIPAL \\
\hline PAC & \\
\hline $\begin{array}{l}\text { Programa Minha Casa, } \\
\text { Minha Vida }\end{array}$ & acesso a 1 milhão de moradias de famílias com renda até 10 salários mínimos \\
\hline FNHIS & Fundo Nacional de Habitação de Interesse Social \\
\hline $\begin{array}{l}\text { Programa Urbanização, } \\
\text { Regularização e } \\
\text { Integração de } \\
\text { Assentamentos Precários }\end{array}$ & $\begin{array}{l}\text { intervenções necessárias à regularização fundiária, segurança, salubridade e habitabilidade de } \\
\text { população localizada em área inadequada à moradia ou em situações de risco, visando a sua } \\
\text { permanência ou realocação, por intermédio da execução de ações integradas de habitação, } \\
\text { saneamento ambiental e inclusão social }\end{array}$ \\
\hline $\begin{array}{l}\text { Habitação de Interesse } \\
\text { Social - HIS }\end{array}$ & \\
\hline $\begin{array}{l}\text { Ação Provisão } \\
\text { Habitacional de Interesse } \\
\text { Social }\end{array}$ & $\begin{array}{l}\text { acesso da população com renda familiar mensal de até } \mathrm{R} \$ 1.050,00 \text { (um mil e cinqüenta reais) à } \\
\text { habitação digna, regular e dotada de serviços públicos, em localidades urbanas ou rurais, mitigando } \\
\text { as desigualdades sociais e contribuindo para a ocupação urbana planejada. }\end{array}$ \\
\hline PROGRAMA / FUNDO & OBJETIVO PRINCIPAL \\
\hline $\begin{array}{l}\text { Ação Provisão } \\
\text { Habitacional de Interesse } \\
\text { Social - Modalidade: } \\
\text { Assistência Técnica }\end{array}$ & $\begin{array}{l}\text { melhoria dos padrões de salubridade, segurança e habitabilidade das edificações produzidas, } \\
\text { reformadas ou ampliadas no âmbito do Fundo Nacional de Habitação de Interesse Social, por } \\
\text { intermédio de apoio à prestação de serviços de assistência técnica, assim entendida como o } \\
\text { conjunto de ações voltadas à mobilização e organização comunitária, elaboração de projetos, } \\
\text { acompanhamento e execução da obra, trabalho social e jurídico, de forma coletiva ou individual. }\end{array}$ \\
\hline PROGRAMA / FUNDO & OBJETIVO PRINCIPAL \\
\hline $\begin{array}{l}\text { Ação Apoio à elaboração } \\
\text { de Planos Habitacionais } \\
\text { de Interesse Social - } \\
\text { PLHIS }\end{array}$ & $\begin{array}{l}\text { formulação dos Planos Locais de Habitação com foco na habitação de interesse social, para que } \\
\text { esses construam com os agentes sociais um conjunto de objetivos, metas, diretrizes e instrumentos } \\
\text { de ação e intervenção para o setor habitacional. }\end{array}$ \\
\hline $\begin{array}{l}\text { Ação de Apoio à } \\
\text { Produção Social da } \\
\text { Moradia }\end{array}$ & $\begin{array}{l}\text { apoiar entidades privadas sem fins lucrativos, vinculadas ao setor habitacional, no desenvolvimento } \\
\text { de ações integradas e articuladas que resultem em acesso à moradia digna, situada em localidades } \\
\text { urbanas ou rurais, voltada a famílias de baixa renda, assim consideradas aquelas que recebam até } \\
\mathrm{R} \$ 1.125,00 \text { (um mil, cento e vinte e cinco reais) de rendimento mensal bruto. }\end{array}$ \\
\hline OGU & Orçamento Geral da União \\
\hline Habitar Brasil BID - HBB & $\begin{array}{l}\text { projeto piloto para financiar obras e ações nos municípios capitais de estado ou integrantes de } \\
\text { regiões metropolitanas e aglomerados urbanos }\end{array}$ \\
\hline $\begin{array}{l}\text { Programa Brasileiro da } \\
\text { Qualidade e Produtividade } \\
\text { do Habitat - PBQP-H }\end{array}$ & $\begin{array}{l}\text { visa elevar os patamares da qualidade e produtividade da construção civil, por meio da criação e } \\
\text { implantação de mecanismos de modernização tecnológica e gerencial, contribuindo para ampliar o } \\
\text { acesso à moradia para a população de menor renda. }\end{array}$ \\
\hline
\end{tabular}

95 Idem. 


\begin{tabular}{|c|c|}
\hline $\begin{array}{l}\text { Programa de Subsídio à } \\
\text { Habitação de Interesse } \\
\text { Social - PSH }\end{array}$ & $\begin{array}{l}\text { oferecer acesso à moradia adequada a cidadãos de baixa renda por intermédio da concessão de } \\
\text { subsídios. }\end{array}$ \\
\hline $\begin{array}{l}\text { Projetos Prioritários de } \\
\text { Investimentos - PPI } \\
\text { (Intervenções em Favelas) }\end{array}$ & $\begin{array}{l}\text { As intervenções propostas deverão ter como objetivo precípuo a implantação de ações } \\
\text { necessárias à regularização fundiária, segurança, salubridade e habitabilidade de população } \\
\text { localizada em área inadequada à moradia, visando a sua permanência ou realocação, por } \\
\text { intermédio da execução de ações integradas de habitação, saneamento e inclusão social }\end{array}$ \\
\hline - $\quad$ FGTS & Fundo de Garantia por Tempo de serviço \\
\hline Carta de Crédito Individual & $\begin{array}{l}\text { conceder financiamentos a pessoas físicas para fins de aquisição, construção, conclusão, } \\
\text { ampliação, reforma ou melhoria de unidade habitacional, propiciando ainda a aquisição de cesta de } \\
\text { material de construção ou a aquisição de lote urbanizado. }\end{array}$ \\
\hline $\begin{array}{l}\text { Carta de Crédito } \\
\text { Associativo }\end{array}$ & $\begin{array}{l}\text { conceder financiamentos a pessoas físicas, associadas em grupos formados por condomínios, } \\
\text { sindicatos, cooperativas, associações, Companhias de Habitação (COHAB) ou empresas do setor } \\
\text { da construção civil / Aquisição e construção de Unidades Habitacionais, Reabilitação Urbana e } \\
\text { Produção de Lotes Urbanizados. }\end{array}$ \\
\hline $\begin{array}{l}\text { Programa de Atendimento } \\
\text { Habitacional através do } \\
\text { Poder Público - Pró- } \\
\text { Moradia }\end{array}$ &  \\
\hline FAR & Fundo de Arrendamento Residencial \\
\hline $\begin{array}{l}\text { Programa de } \\
\text { Arrendamento Residencial } \\
\text { - PAR }\end{array}$ & $\begin{array}{l}\text { O Programa de Arrendamento Residencial (PAR) tem por objetivo propiciar moradia à população de } \\
\text { baixa renda, sob a forma de arrendamento residencial com opção de compra. }\end{array}$ \\
\hline FDS & Fundo de Desenvolvimento Social \\
\hline $\begin{array}{l}\text { Programa Crédito } \\
\text { Solidário }\end{array}$ & $\begin{array}{l}\text { financiamento habitacional a famílias de baixa renda organizadas em associações, cooperativas, } \\
\text { sindicatos ou entidades da sociedade civil organizada. }\end{array}$ \\
\hline FAT & Fundo de Amparo ao Trabalhador \\
\hline $\begin{array}{l}\text { PMI - Projetos } \\
\text { Multissetoriais Integrados }\end{array}$ & $\begin{array}{l}\text { Oferecer, no âmbito dos Projetos Multissetoriais Integrados - PMl, operados pelo Banco Nacional de } \\
\text { Desenvolvimento Econômico e Social - BNDES, acesso à infra-estrutura urbana, à moradia } \\
\text { adequada e aos serviços públicos básicos para a população em situação de vulnerabilidade social e } \\
\text { com rendimento familiar mensal preponderante de até } 3 \text { salários mínimos, por intermédio do } \\
\text { financiamento de projetos de investimentos e ações integradas em assentamentos precários. }\end{array}$ \\
\hline
\end{tabular}

Fonte: Relatório do Ministério das Cidades, 2005.

A concepção desses programas claramente reflete um compromisso ideológico com a democracia, a participação e o cumprimento da função social da cidade e da propriedade urbana, indo em direção diametralmente oposta à política habitacional excludente empreendida pelo BHN. Segundo Maricato:

"As inúmeras propostas de política urbana que não saíram do papel após 1985 e a pouca eficácia que teve a política autoritária do regime militar reforçam a convicção de que apenas uma formulação que resulte de um pacto social e um pacto federativo teria a durabilidade, a legitimidade e a eficácia para as transformações pretendidas. Para a equipe que coordenou os primeiros passos da Política Nacional de Desenvolvimento Urbano (PNDU) no Ministério das Cidades, tratava-se de construir uma nova "cultura" para ocupar um vazio de propostas práticas abrangentes, dar espaço para a emergência dos conflitos, constituir pactos em torno de conceitos, programas e linhas de ações. Buscou-se edificar um espaço 
público participativo que pudesse resistir à cultura de privatização da esfera pública, bem como ao avanço das imposições anti-sociais da globalização. A abertura de espaços democráticos nos quais os conflitos possam se expressar não é algo banal na história do país. Trata-se de uma mudança que pode desencadear novas e sucessivas transformações". (MARICATO, 2006b, p.215)

Mas, por outro lado, enquanto busca-se a superação do modelo habitacional do regime militar, o Programa Minha Casa Minha Vida (PMCMV), lançado em 2009 pelo Governo Federal, entra no rol das políticas massivas de habitação, com pretensão de financiar a construção de 1 milhão de novas moradias para as faixas de renda até 10 salários mínimos, com subsídios para aquisição de imóveis de acordo com as fixas de renda de 0 - $3 \mathrm{sm}, 3$ - $6 \mathrm{sm}$ e 6 - 10sm.

Antecipando instrumentos e ações dentro do Plano Nacional de Habitação, o diferencial da política de subsídio governamental é o acesso às populações de baixa renda, principalmente da faixa de $0-3 \mathrm{sm}$, tradicionalmente excluídas, ao financiamento da casa própria, tendo em vista que esse foi uma dos principais problemas na política habitacional do $\mathrm{BNH}$.

Mas esse não é o escopo único do Programa. Tentando aliar uma solução (parcial) para o déficit habitacional com o "aquecimento" do mercado da construção civil, através do PMCMV o Governo Federal justifica uma ação protecionista ao mercado, pela produção massiva da moradias, dessa vez tendo como grande aliado na produção habitacional não somente companhias estaduais e municipais de habitação, como foi no $\mathrm{BNH}$, mas também a iniciativa privada, como forma também de enfrentamento da crise internacional que ocorreu nesse ano.

\subsubsection{Plano de Saneamento Básico (Lei 11.445/2007 Nacional do Saneamento Básico)}

Segundo levantamento do Ministério das Cidades, baseados em dados no Brasil, 83 milhões de pessoas, quase $50 \%$ da população, não é atendida por sistemas de esgoto, e 45 milhões não têm acesso serviços de água potável, e quase $60 \%$ dos esgotos são lançados diretamente nos mananciais, sem receber tratamento. Os problemas maiores de saneamento estão concentrados nos bolsões de pobreza das grandes cidades, e especialmente no Norte e Nordeste (MINISTÉRIO DAS CIDADES, 2004d, p. 18). 
Após a extinção do PLANASA, com a finalização dos prazos de contratos de prestação de serviços das concessionárias estaduais, e ausência de novos planos na após 15 anos de sem legislações e políticas específicas para o saneamento, a Política Nacional de Saneamento Ambiental, aprovada em 2007 como a Lei do Saneamento Básico (Lei n. 11.445/2007) é o novo marco regulatório do saneamento ambiental nacional que vem tentar reorganizar a prestação de serviço no setor.

O texto da PNDU em 2004 já pautava a questão, no que passou a ser da competência da União:

\begin{abstract}
"No saneamento básico a competência da esfera federal para legislar sobre estes serviços públicos está restrita a dois aspectos: 1) instituir diretrizes definidoras da natureza e dos padrões mínimos da prestação dos serviços públicos; 2) instituir uma Política Nacional de Saneamento Ambiental a que estados e municípios possam aderir em função do planejamento integrado que o setor requer." (MINISTÉRIO DAS CIDADES, 2004a, p. 66).
\end{abstract}

Os princípios da universalidade, da integralidade, da qualidade e regularidade dos serviços, da transparência das ações, do controle social e da integração de políticas, coloca a Política de Saneamento no campo das políticas públicas de referenciais universalistas, alinhada ao Estatuto das Cidades e a Lei Orgânica da Saúde n. 8.080/1990, que circunscrevem o saneamento como um direito social e recolocam a responsabilidade do Estado na sua promoção (BORJA, 2008).

Dentre as muitas contribuições e inovações da Lei, um marco é a exigência legal da ação do planejamento do setor, devendo os titulares do serviço formularem a política pública de saneamento básico, e para tanto elaborarem o Plano de Saneamento Básico - o PLANSAB (cf. art. 9‥, do Capítulo II ,BRASIL, 2007a).

O PLANSAB ainda está em vias de implementação, mas é notória a relevância do Plano como eixo central da atuação do Governo Federal, por se tornar o responsável pela definição de programas, ações e estratégia de investimento no setor. Tanto que a concessão dos serviços, o financiamento, a validade dos contratos pela nova Lei ficam condicionados à existência do Plano.

O Plano pressupõe uma abordagem intersetorial da problemática do saneamento básico e demanda a existência de um conselho municipal para sua execução e controle 
social. Difere do PLANASA pelo caráter local dos planos, e não um plano único de dimensões federais, mas como no PLANASA, tem-se a descentralização dos serviços de saneamento, não centrada nos Estados, mas nos municípios.

O quadro da prestação de serviços de água e esgoto é hoje formado por inúmeras prestadoras de serviço de abrangência local, regional ou microrregional, na forma de autarquias, empresas privadas, sociedades de economia mista com administração pública, ou administração pública direta, cobrindo a quase totalidade municípios brasileiros.

Tabela 12 - Distribuição dos prestadores de serviço participantes do SNIS em 2008, segundo características de atendimento.

Distribuição dos prestadores de serviços participantes do SNIS em 2008, segundo características do atendimento

\begin{tabular}{|l|r|r|r|r|r|}
\hline \multicolumn{2}{|c|}{ Prestador de serviços } & \multicolumn{2}{c|}{$\begin{array}{c}\text { Populaçāo urbana dos } \\
\text { municípios atendidos }\end{array}$} & \multicolumn{2}{c|}{$\begin{array}{c}\text { Quantidade de municípios } \\
\text { atendidos }\end{array}$} \\
\hline Abrangência & Quantidade & $\begin{array}{c}\text { Água } \\
\text { (GE006a) }\end{array}$ & $\begin{array}{c}\text { Esgotos } \\
\text { (GE006b) }\end{array}$ & $\begin{array}{c}\text { Água } \\
\text { (GE005a) }\end{array}$ & $\begin{array}{c}\text { Esgotos } \\
\text { (GE005b) }\end{array}$ \\
\hline Regional & 26 & 116.455 .034 & 87.844 .464 & 3.980 & 1.082 \\
\hline Microrregional & 7 & 663.572 & 604.573 & 20 & 14 \\
\hline Local & 628 & 36.463 .402 & 32.517 .216 & 627 & 372 \\
\hline Brasil & 661 & 153.582 .008 & 120.966 .253 & 4.627 & 1.468 \\
\hline
\end{tabular}

Fonte: SNIS, $2008^{96}$.

Segundo dados do SNIS $(2004)^{97}$ a análise dos índices gerais de atendimento urbano em termos de abastecimento de água mostra uma média nacional da ordem de 95,4\% em 2004, que sofrerá uma leve queda em 2008 (cf. Tabela 13). Regionalmente, vê-se que o Norte e Nordeste em 2008, ainda permanecem com a menor cobertura regional, abaixo da média nacional.

Em termos de esgotamento sanitário, em 2004, o relatório do SNIS aponta que o atendimento urbano com coleta apresenta um índice médio nacional ainda precário, igual a 50,3\%, índice que tem um ligeira elevação para 50, 6\% em 2008. Nesse ano, os índice de Norte, Nordeste e Sul pode-se dizer que permanecem sofríveis, chegando a Região Norte a apenas $7 \%$ de cobertura de esgoto.

\footnotetext{
${ }^{96}$ MINISTÉRIO DAS CIDADES, Secretaria Nacional de Saneamento Ambiental, Programa Nacional de Modernização do Setor de Saneamento. Programa de Sistema Nacional de Informações Sobre Saneamento - SNIS. Diagnóstico Dos Serviços de Água e Esgoto. 2008.

${ }^{97}$ Ibidem, Visão Geral da Prestação dos Serviços de Água e Esgotos, 2004.
} 
O Relatório aponta que "o elevado déficit com os serviços de esgotamento sanitário explica-se, em parte, pela ausência das companhias estaduais de saneamento na grande maioria dos municípios brasileiros no que diz respeito a esses serviços, onde enquanto tais companhias atuam com serviços de água em 3.887 municípios (70\% do total de municípios brasileiros) em relação aos serviços de esgotos a quantidade cai para apenas 894 (16,0\% do total de municípios do país)".

Em relação ao tratamento dos esgotos os resultados de melhora são mais expressivos, passando de um índice médio nacional de tratamento dos esgotos gerados na área urbana de apenas $31,3 \%$ para $34,6 \%$. Destaca-se nesse aspecto a região Centro-Oeste com índices de tratamento urbano acima da média nacional.

Tabela 13 - Níveis de atendimento com água e esgotos dos prestadores de serviços participantes do SNIS em 2008, por região demográfica.

Níveis de atendimento com água e esgotos dos prestadores de serviços participantes do SNIS em 2008, segundo região geográfica

\begin{tabular}{|c|c|c|c|c|c|}
\hline \multirow{3}{*}{ Regiöes } & \multicolumn{4}{|c|}{ Índice de atendimento (\%) } & \multirow{3}{*}{$\begin{array}{c}\text { Indice de } \\
\text { tratamento dos } \\
\text { esgotos gerados }(\%) \\
\text { Total } \\
\left(\mathrm{IN}_{\text {O46 }}\right)\end{array}$} \\
\hline & \multicolumn{2}{|c|}{ Água } & \multicolumn{2}{|c|}{ Coleta de esgotos } & \\
\hline & $\begin{array}{l}\text { Total } \\
\left(I N_{05 s}\right)\end{array}$ & $\begin{array}{l}\text { Urbano } \\
\left(1 \mathrm{~N}_{023}\right)\end{array}$ & $\begin{array}{c}\text { Total } \\
\left(\mid \mathrm{NN}_{056}\right)\end{array}$ & $\begin{array}{l}\text { Urbano } \\
\left(\mathrm{IN}_{\text {oas }}\right)\end{array}$ & \\
\hline Norte & 57,6 & 72,0 & 5,6 & 7,0 & 11,2 \\
\hline Nordeste & 68,0 & 89,4 & 18,9 & 25,6 & 34,5 \\
\hline Sudeste & 90,3 & 97,6 & 66,6 & 72,1 & 36,1 \\
\hline Sul & 86,7 & 98,2 & 32,4 & 38,3 & 31,1 \\
\hline Centro-oeste & 89,5 & 95,6 & 44,8 & 49,5 & 41,6 \\
\hline Brasil & 81,2 & 94,7 & 43,2 & 50,6 & 34,6 \\
\hline
\end{tabular}

Fonte: SNIS, $2008^{98}$.

Embora se perceba avanços na legislação e regulação do setor com a PMDU, e algum nível de melhoria dos índices de saneamento, o grande volume de assentamentos precários ou subnormais nas metrópoles e grandes cidades sem infraestrutura de saneamento, ou mesmo a inexistência de cobertura de coleta de esgoto em regiões como a Amazônia, por exemplo, revela ainda a insuficiência de investimentos ou políticas adequadas ou o direcionamento de ambos para áreas que não sejam exatamente as de maior PIB, como a Sudeste ou Centro-Oeste, revertendo-

\footnotetext{
${ }^{98}$ MINISTÉRIO DAS CIDADES, Secretaria Nacional de Saneamento Ambiental, Programa Nacional de Modernização do Setor de Saneamento. Programa de Sistema Nacional de Informações Sobre Saneamento - SNIS. Diagnóstico Dos Serviços de Água e Esgoto. 2008.
} 
se tendência histórica de concentração regional que tem se observado nas políticas de desenvolvimento urbano.

\title{
5.2.4. O Programa de Aceleração do Crescimento - PAC (1)
}

Mantendo a "tradição" dos grandes planos nacionais de investimento em infraestrutura, o Programa de Aceleração do Crescimento foi lançado no segundo mandato do Governo Lula, em 2007. O discurso governamental era de que:

\begin{abstract}
"Mais que um plano de expansão do investimento, o PAC quer introduzir um novo conceito de investimento em infra-estrutura no Brasil. Um conceito que faz das obras de infra-estrutura um instrumento de universalização dos benefícios econômicos e sociais para todas as regiões do País. O PAC vai estimular, prioritariamente, a eficiência produtiva dos principais setores da economia, impulsionar a modernização tecnológica, acelerar o crescimento nas áreas já em expansão e ativar áreas deprimidas, aumentar a competitividade e integrar o Brasil com seus vizinhos e com o mundo. Seu objetivo é romper barreiras e superar limites. Um programa dessa magnitude só é possível por meio de parcerias entre o setor público e o investidor privado, somadas a uma articulação constante entre os entes federativos (estados e municípios)."
\end{abstract}

Segundo os dados oficiais, o PAC (Programa de Aceleração do Crescimento) trata-se de um grande projeto - grande em objetivos, abrangência territorial e recursos investidos - de investimento na infra-estrutura do País, na construção de portos, aeroportos, estradas, hidrelétricas, energia, habitação, saneamento, etc, que foram considerados investimentos prioritários para o crescimento econômico nacional.

Tendo em vista a obtençao de resultados a curto prazo, a estratégia de ação do governo federal baseou-se na recuperação da infra-estrutura existente, em concluir projetos em andamento e buscar novos projetos com forte potencial para gerar desenvolvimento econômico e social - "além de estimular, decididamente, a sinergia entre estes projetos". Na verdade, foi proposto como resposta do governo à crise internacional, como uma tentativa de dinamização da economia por meio da indústria da construção civil, para movimentar recursos e gerar empregos.

Lançado em 2007, com obras previstas até 2010, a primeira etapa do PAC envolveu uma ordem vultosa de recursos da ordem de 500 bilhões de reais com recursos provenientes da União, das empresas estatais e da iniciativa, confirme podese ver no Gráfico 17. 


\section{Gráfico 17 - Origem dos Recursos do PAC 1}

\section{ORIGEM DOS RECURSOS DO PAC 1 (Total de 503,9 bilhões)}

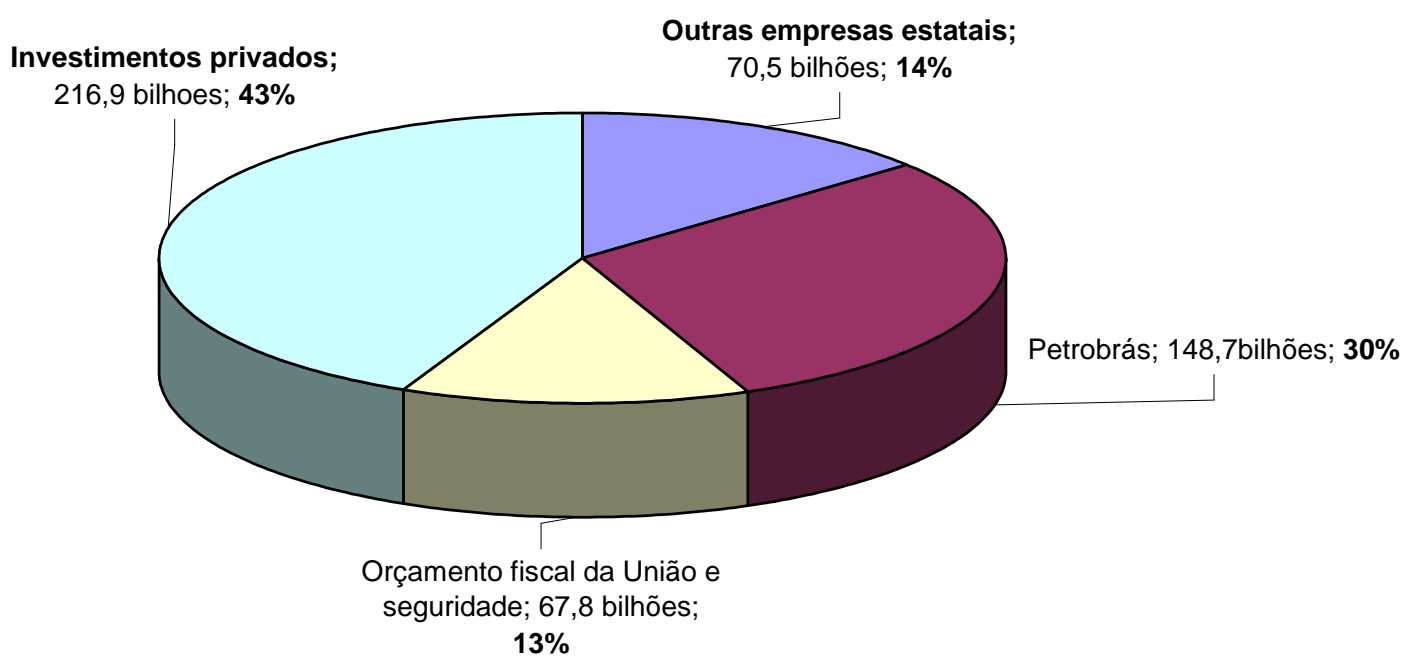

Fonte: PAC, informações oficias (gráfico elaborado pela autora)

Os investimentos foram divididos em três eixos:

- Infraestrutura Logística, envolvendo a construção e ampliação de rodovias, ferrovias, portos, aeroportos e hidrovias;

- Infraestrutura Energética, correspondendo a geração e transmissão de energia elétrica, produção, exploração e transporte de petróleo, gás natural e combustíveis renováveis; e

- Infraestrutura Social e Urbana, englobando saneamento, habitação, metrôs, trens urbanos, universalização do programa Luz para Todos e recursos hídricos (BRASIL, 2010).

Para a Infraestrutura Logística, a previsão de investimentos de 2007 a 2010 é de $R \$ 58,3$ bilhões; para a Energética, $R \$ 274,8$ bilhões; e para a Social e Urbana, $R \$ 170,8$ bilhões, o que gera a seguinte proporcionalidade em termos gráficos: 
Gráfico 18 - Destino dos investimentos do PAC 1 - POR EIXO

\section{DESTINO DOS INVESTIMENTOS DO PAC-1 POR EIXO}

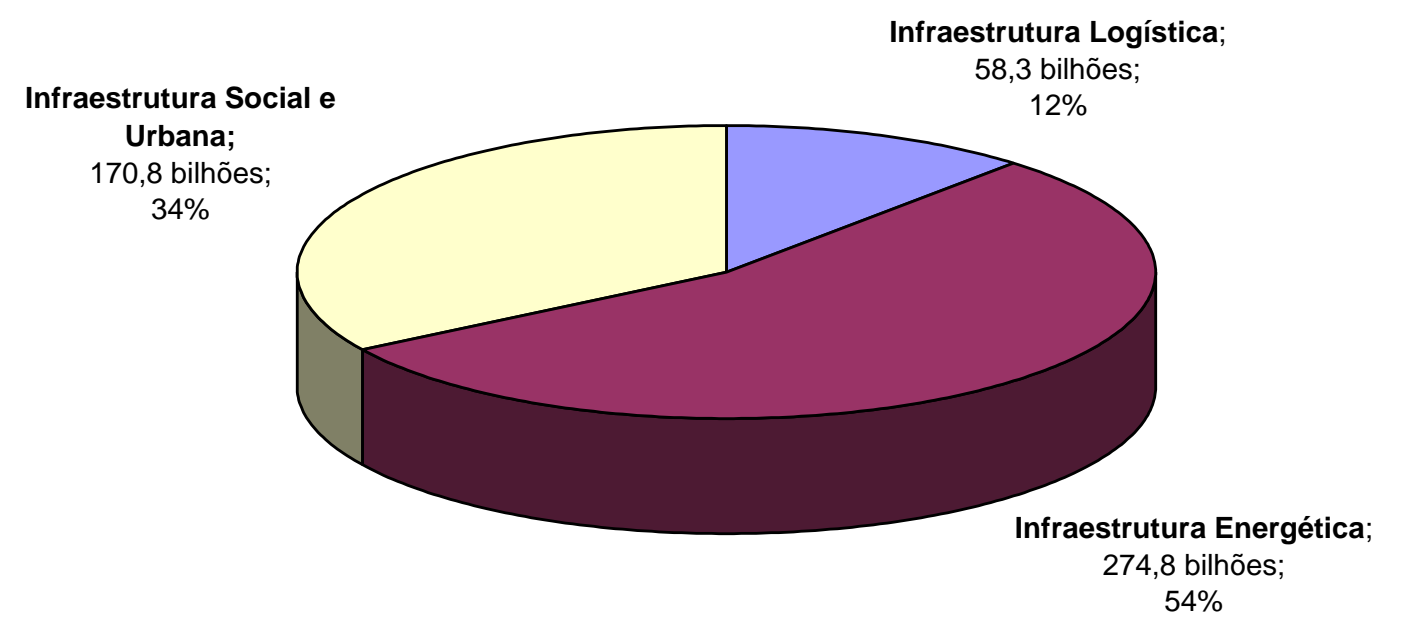

Fonte: PAC, informações oficias (gráfico elaborado pela autora)

\section{ORIGEM DOS RECURSOS DO PAC 1 (Total de 503,9 bilhões)}

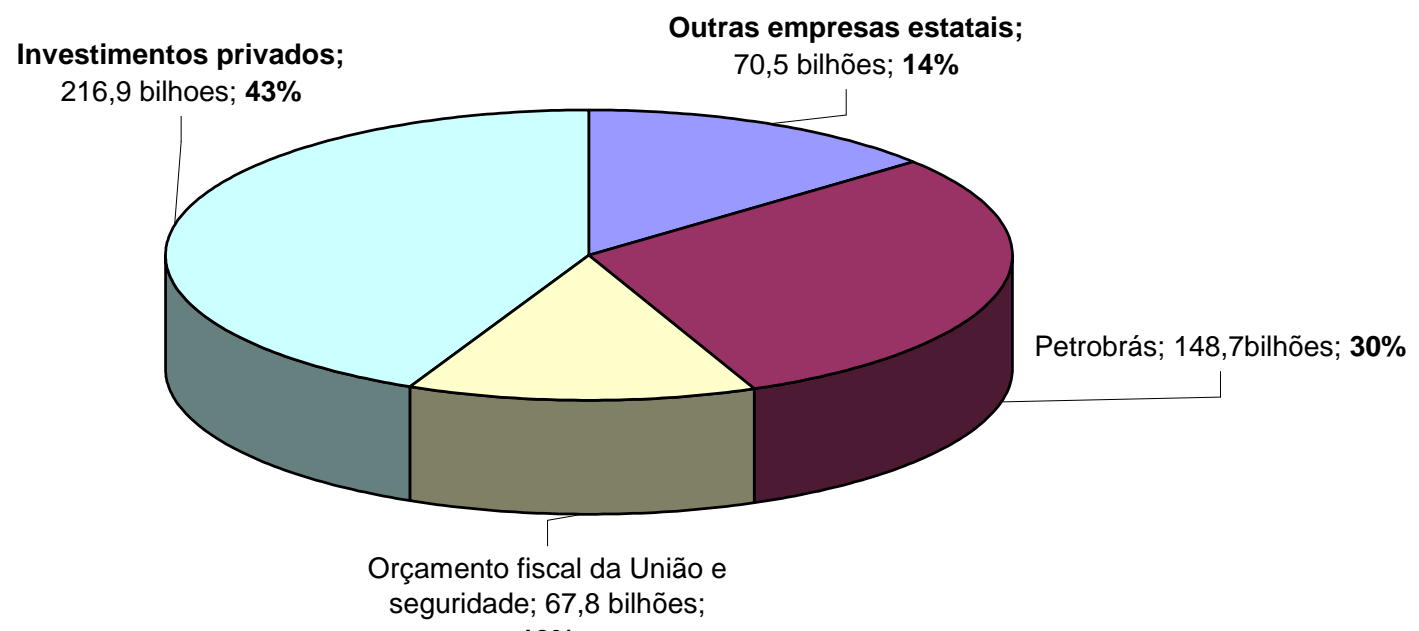

$13 \%$ 
Em termos mais detalhados, da destinação dos recursos dentro de cada eixo, tem-se o seguinte:

- $\mathrm{R} \$ 274,8$ bilhões deverão ser investidos em Energia (inclui petróleo), assim divididos [7]

- $\mathrm{R} \$ 65,9$ bilhões para geração de energia elétrica

$\mathrm{R} \$ 12,5$ bilhões para transmissão de energia elétrica

$\mathrm{R} \$ 179,0$ bilhões para petróleo e gás natural

$R \$ 17,4$ bilhões para combustíveis renováveis.

- $\mathrm{R} \$ 170,8$ bilhões serão investidos em Infra-Estrutura Social e Urbana, assim divididos:

- $\mathrm{R} \$$ 8,7 bilhões para o projeto Luz Para Todos

- $\mathrm{R} \$ 40,0$ bilhões para projetos de saneamento básico

- $\mathrm{R} \$ 106,3$ bilhões para projetos de habitação

- $\mathrm{R} \$ 3,1$ bilhões para Metrôs

- $\mathrm{R} \$ 12,7$ bilhões para recursos hídricos.

- $\quad \mathrm{R} \$ 58,3$ bilhões serão investidos em Logística, assim distribuídos:
- $\mathrm{R} \$ 33,4$ bilhões para rodovias
$R \$ 7,9$ bilhões para ferrovias
$\mathrm{R} \$ 2,7$ bilhões para portos
$\mathrm{R} \$ 3,0$ bilhões para aeroportos
$\mathrm{R} \$ 700$ milhões para hidrovias
$\mathrm{R} \$ 10,6$ bilhões para marinha mercante.

O Gráfico 19 mostra a proporcionalidade desse investimentos. De acordo com balanço divulgado pela Casa cCvil em junho de 2009, o PAC concluiu $15,1 \%$ do total programado.

Gráfico 19 - Volume de investimentos previstos segundo as áreas prioritárias do PAC 1

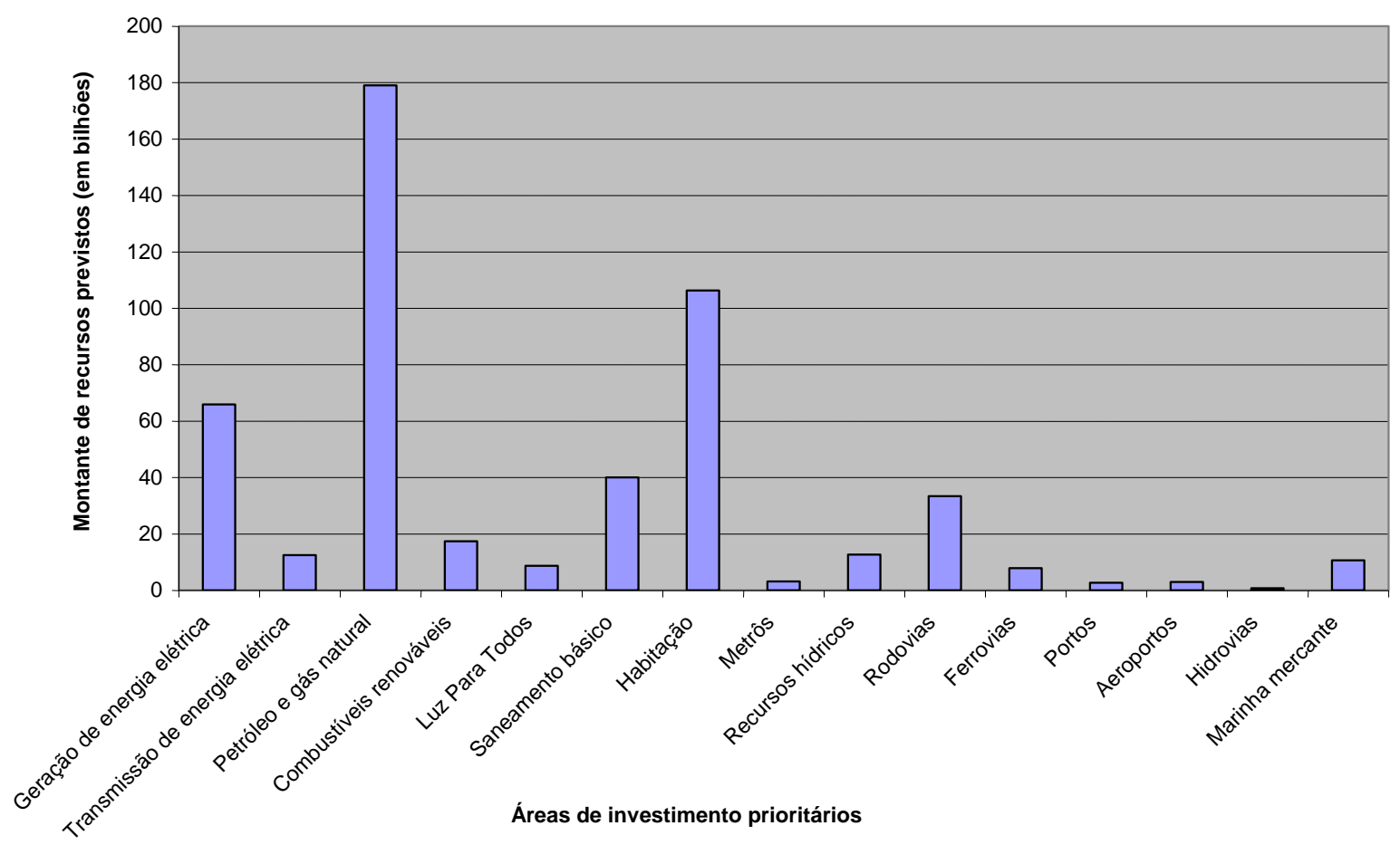


ORIGEM DOS RECURSOS DO PAC 1 (Total de 503,9 bilhões)

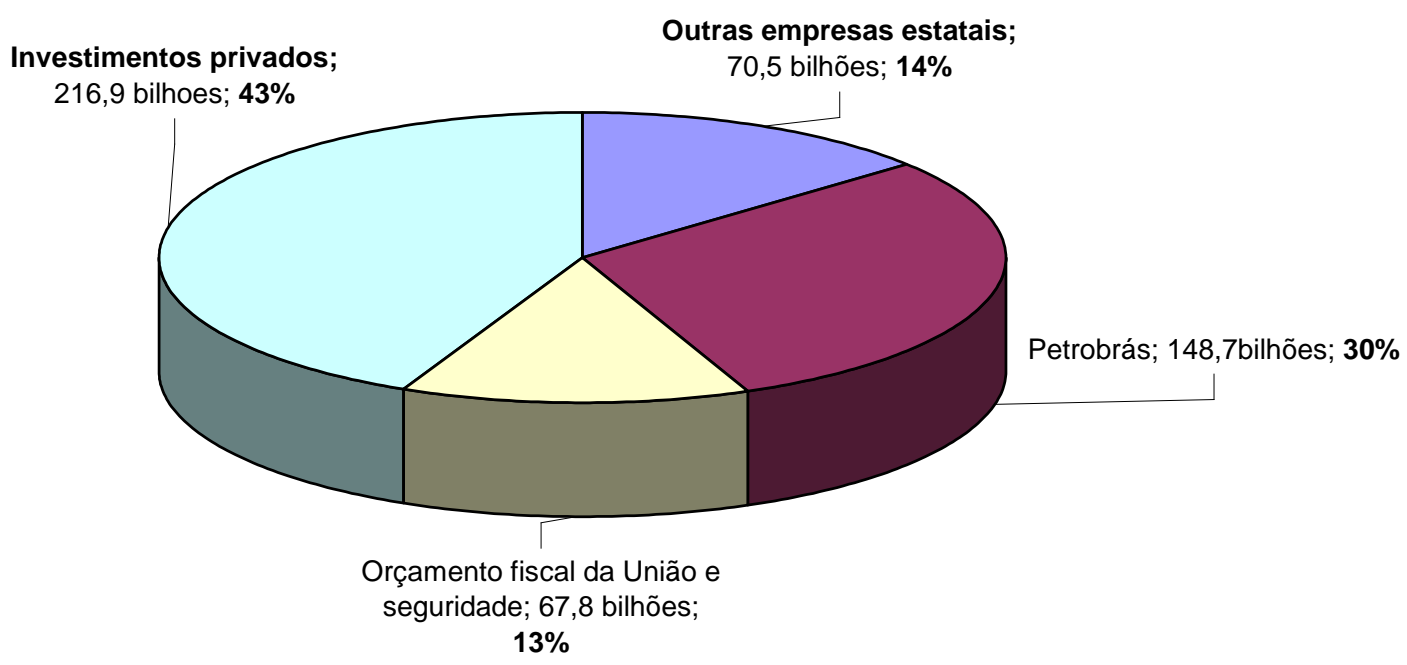

Fonte: PAC, informações oficias (gráfico elaborado pela autora)

No tocante a intervenções urbanísticas, o PAC previu obras nos setores de habitação, saneamento e transportes, com projetos em várias cidades e regiões do País, com a seguinde "natureza"

\section{HABITAÇÃO}

- Urbanização de Assentamentos Precários

- Produção Habitacional

- Produção Habitacional - Assistência Técnica

- Planos Habitacionais de Interesse Social

TRANSPORTES

- Metrô

- Trem Urbano

- Eixo de Integração

- Terminal Fluvial

- Corredor Expresso

- BRs

SANEAMENTO E ABASTECIMENTO

- Saneamento Integrado

- Drenagem Urbana

- Esgotamento Sanitário

- Abastecimento de Água

- Perímetro Irrigado

- Barragem

- Adutora

- Canal

- Perímetro Irrigado

- Sistema Adutor

- Sistema de Abastecimento

- Melhorias Sanitárias Habitacionais

- Resíduos Sólidos

- Melhorias Sanitárias Domiciliares

- Saneamento em Escolas

99 Levantamento feito a partir da listagem de obras do PAC. Disponível em < http://media.folha.uol.com.br/brasil/2008/03/20/lista_das_obras.pdf> 25.06.2010. 
As obras do PAC como são colocadas aparentemente não guardam nenhuma relação com o planejamento territorial municipal, ou diretrizes de planos diretores, parecendo uma sobreposição de projetos isolados setorialmente, com impactos pontuais sobre certas áreas das cidades, metrópoles ou regiões.

Se por um lado, parece não promover interstorialidade nem intregaçao territorial dentro de um plano, por outro enquadra-se em uma das diretrizes da Política Nacional de Desenvolvimento Urbano de 2004 , de "promover políticas abrangente e massivas para o enfrentamento de grandes problemas urbanos como déficit habitacional, regularização fundiária".

Tendo feito uma análise mais detalhada sobre os impactos da dimensão territorial do PAC, Leitão (2009) afirma que o PAC foi lançado num contexto de manutenção da "estabilização macroeconômica" ainda dentro da cartilha neoliberal e "neo-desenvolvimentista", com o estado retomando os investimentos públicos com potencial para elevação das taxas de crescimento da economia, como confirma o discurso governamental: "A consistência dos números sobre o investimento mais uma vez corrobora a estratégia do Governo Federal, no sentido de apoiar a formação de capital pelo setor privado e, simultaneamente, aumentar o investimento público em infra-estrutura"100.

A autora também concorda que os discursos de "crescimento sustentado" e de "programa integrado de desenvolvimento" que aparece em alguns momentos não se sustentam, e classifica o projeto como uma somatória de ações dispersas e desarticuladas, sem apoiar-se em políticas econômicas que de fato the dêem um caráter de "sustentabilidade" na contribuição para o crescimento do País, e sem ter um projeto territorial de fato subjacente a suas propostas, reforçando as políticas setorialistas, desarticuladas e fragmentas sobre o território.

100 BRASIL. BALANÇO DO PAC - 2 ANOS. Fevereiro de 2009. Disponível em <http://www.brasil.gov.br/pac/relatorios/por-balanco/balanco-2-anos> Acesso em 22.06.10. 


\subsection{Considerações sobre os Planos, programas e ações}

Confrontando os documentos oficiais com avaliações técnicas e acadêmicas mais a evidência empírica que se experimenta enquanto cidadão, tem-se uma dimensão desse desafio da implementação das diretrizes das PNDUs no cotidiano das municipalidades ou metrópoles.

Em termos de concepção, pode-se dizer que o Ministério das Cidades representa um avanço significativo no contexto histórico do urbanismo no Brasil. Mas avaliar a factibilidade e impactos de suas propostas, não cabe no escopo desta pesquisa, seja pela proximidade temporal aos fatos, seja pelos caminhos escolhidos, de comparar proposições. 


\section{Capítulo 6}




\section{Capitulo6}

\section{CONSIDERAÇÕES FINAIS}

Tendo como foco as políticas nacionais de desenvolvimento urbano de 1975 e 2004, a pesquisa buscou fazer uma sistematização das duas únicas políticas urbanas nacionais desenvolvidas em nível federal, e identificar através da análise comparativa dessas experiências, proximidades e distanciamentos, continuidades e descontinuidades entre seus princípios e fundamentos, conteúdos, programas e ações, bem como fatores que limitaram ou não sua contribuição ao desenvolvimento urbano do país.

Buscou-se investigar por que meios as políticas urbanas se fizeram implementar. Não só a política urbana como diretriz, mas também seus instrumentos e meios de ação essenciais para a sua prática pelo Estado e governos competentes, conforme as determinações constitucionais e, atualmente, do Estatuto da Cidade. Observou-se que foram vários os fatores que as condicionaram, como os meios legais, institucionais e fiscais, por exemplo. Outra questão foi territorial, metropolitana, regional procurando-se entender como as políticas trataram cada uma dessas escalas, ou como uma política definida na esfera federal, se fez concretizar na escala municipal, na cidade.

Procurou-se então, ao longo da tese, pontuar os planos que foram desenvolvidos no período militar, "quando toda uma práxis política sobre o território percorreu os principais planos governamentais do período - em especial o II PND, que define a primeira PNDU - acatando-se o conceito de planejamento enquanto instrumento norteador - dentro de um clima desenvolvimentista - para o desenvolvimento econômico do Brasil" (BOMFIM, 2007), estendendo-se a contextualização histórica até os períodos mais recentes, de crises - econômica e urbana - até à tentativa de "renovação" conceitual da visão de cidade para o desenvolvimento de uma política urbana nacional

Na Política Urbana Nacional de 1975, uma gama de programas e projetos são descritos no escopo da política, mas dentre os planos tiveram destaque o PLANASA de 
saneamento e o Plano Habitacional - não obstante a forma como foram concebidos e implementados - e o Programa de Cidades Médias, que visava investir nas cidades até 500 mil habitantes de forma a alavancar o desenvolvimento, principalmente econômico, dessas cidades. Dentre os projetos, o Projeto CURA de recuperação urbana prioritária de algumas cidades, previa e provia a instalação de equipamentos e melhorias urbanas. Na PNDU de 2004, os planos habitacionais e de saneamento também são destaque, mas além destes, os diversos instrumentos de regularização fundiária compreendidos no Estatuto das Cidades, e propostas do PAC e o Programa MCMV, lançado em fins de 2009.

I

Ao longo da pesquisa viu-se que a política urbana como pauta na agenda governamental ganhou destaque quando as cidades passaram a ser o cenário principal da crise social e econômica que se abateu sobre a população com a industrialização e exploração do capital sobre as cidades.

A urbanização acelerada a partir de meados do século $X X$, e as demandas da industrialização "modernizadora" foram o ponto de partida para intensificação dos problemas urbanos e da atenção às políticas urbanas pelo governo federal no Brasil. Esse fato marcante direcionou a ação do Estado para o investimento na estruturação física e econômica de determinadas regiões, de modo a oferecer as condições necessárias à produção e acumulação do capitalismo industrial tardio que aqui se instalou.

A partir da modernidade industrial, o Estado passou a desenvolver 0 "planejamento urbano", ou seja, definir os planos, programas e projetos a serem desenvolvidos pelo poder público para "ordenar" a expansão e desenvolvimento das cidades. O planejamento envolveu as propostas de "ações", seja no espaço urbano, seja nas regiões e territórios, enquanto as políticas urbanas seriam a formatação administrativa e legal para implementação dessas ações. Ou seja, a política urbana seria o aparato normativo, jurídico e executivo que determina os rumos do desenvolvimento urbano, em suas várias instâncias.

Esse é o contexto que fomenta a criação da política urbana em 1975, influenciada pelo projeto geopolítico do regime militar que definia estratégias nacionais 
de forma a assegurar "o poder" e a soberania do Estado nos diversos setores. A geopolítica como uma "estratégia de poder" dos governos, foi o projeto políticoterritorial da tecnocracia militar que moldou a primeira PNDU, de 1975, com o projeto "Brasil grande potência". Utilizou-se da ideologia do planejamento para impor o ideário racionalista-positivista para infundir a idéia da grandeza nacional, do "milagre do desenvolvimento". Por ocasião da segunda PNDU a geopolítica, ainda que em outra perspectiva, também está presente como projeto de governo de assumir posições estratégicas no relacionamento com as demais potências mundiais.

Mas a formatação da nova Política dá-se no âmbito de uma perspectiva de aquisição de direitos, que se expressa em todo o perfil da Constituição de 1988 . A Política Urbana consta pela primeira vez em capítulo próprio no texto constitucional e se expressa nos artigos 182 e 183. Ainda que esta seja a matriz que orientará o processo conduzido pelo Ministério das Cidades, a partir de sua criação, em 2001, 0 documento que se considerou nesta pesquisa é o que consta na publicação "Cadernos MCidades" n 1, de 2004, que trata da Política Nacional de Desenvolvimento Urbano, considerada então como PNDU 2004. Em relação à PNDU 1975, a fonte de referência é o documento publicado pelo Ministério do Interior, Secretaria Geral, em 1975, II Plano Nacional de Desenvolvimento; programa de ação do governo na área do desenvolvimento, do qual se considerou o capítulo 5: "Política de desenvolvimento urbano".

\section{II}

Num quadro sinótico das principais características das PNDU, na PNDU de 1975 tem-se uma resolução ministerial, elaborada em processo fechado, restrita a um círculo técnico-burocrático, sem participação da sociedade, centralizado e marcado pelo contexto do autoritarismo ditatorial e desenvolvimentismo econômico, em meio às intempéries crescentes do processo de urbanização e problemas regionais e metropolitanos.

Na PNDU de 2004, tem-se um processo continuado de construção da política urbana determinada constitucionalmente, elaborado num processo amplo de discussão, com participação de diversos segmentos da sociedade e do poder público, num contexto de redemocratização, descentralização, onde o Estado, por mais contraditório que pareça, tenta viabilizar negociações e acordo com os diversos 
segmentos, em meio a pressões constantes dos agentes privados e às crises e déficits notórios nos sistemas urbanos e intra-urbanos.

Pode-se dizer também que a trajetória das duas políticas nacionais de desenvolvimento urbano formuladas no Brasil é marcada por descontinuidades e continuidades em vários aspectos. A descontinuidade se dá em função das mudanças políticas, econômicas e sociais ocorridas nas últimas décadas, indo da centralização à descentralização, do autoritarismo à participação, e do desenvolvimentismo ao neoliberalismo (e novamente a um neo-desenvolvimentismo?).

A continuidade se dá justamente no cerne da questão urbana: a continuidade da crise urbana e regional, da atuação "enviesada" do poder público, da dificuldade de se transpor os discursos de equilíbrio regional, desenvolvimento urbano justo e igualitário, "cidade para todos", em programas e ações que efetivamente reduzam os desequilíbrios regionais, o déficit habitacional, a acessibilidade de transportes, enfim, de superação dos padrões de produção e reprodução do espaço urbano segundo interesses privados e externos em detrimento do cumprimento da função social da cidade e da propriedade urbana.

Os contextos das duas PNDUs também guardam distinções e proximidades. $O$ autoritarismo, o centralismo e a ditadura contrastam com a democratização e abertura à participação social e liberdades políticas atuais. A indústria e a importância da localização de suas bases produtivas da década de 1970, deram lugar à financeirização e transnacionalização do capital da década de 1990, onde as relações importam mais que os lugares, e as fronteiras não são mais barreiras para as negociações nas mais diversas escalas.

As proximidades se apresentam em debates que se revestem de novos discursos, mas se mantém sobre velhos problemas: o clientelismo e o patrimonialismo do Estado; prioridade para as demandas do mercado; problemas urbanos que se agravam paulatinamente; um discurso governamental que pouco se efetiva na prática; políticas urbanas sem implementação.

Como exemplo, a política urbana de 1975 "encomendada" pelo governo federal preconizava a cooperação intergovernamental, mas os investimentos para as regiões e metrópoles eram definidos de acordo com os interesses centrais. Havia o discurso 
governamental da integração territorial, e alguns programas foram propostos nessa direção, mas estava patente a visão de concentração regional, priorizando o fomento às metrópoles do eixo Rio-São Paulo, como forma de aproveitar as economias de aglomeração concentradas nessa região.

Sobre as regiões e escalas, o que era uma estratégia estruturante de "organização" do território na primeira PNDU, na segunda PNDU não encontra praticamente lugar, e foi transferida a outra pasta (Integração Regional), o que se emoldura na atual configuração ministerial é "das Cidades", e não "do Interior" como era em 1975. Nesse período, a estratégia do governo para o desenvolvimento urbano definida em torno das regiões buscava a definição das "vocações" regionais, e a cidade ainda era entendida com "um suporte", como anteriormente já o era na economia agroexportadora, até quando os problemas urbanos se tornam mais evidentes, mas recebendo atenção ainda periférica na PNDU de 1975.

Por outro lado, a visão global de cidade dos técnicos que conceberam a política de 1975 contrastava com a visão setorialista tecnocrática predominante, que se refletia com prioridades de execução de programas dos setores econômicos hegemônicos na aplicação dos recursos e orçamento da união, cuja constituição, segundo SOUZA (2004), era altamente centralizada, ou seja, os recursos recolhidos nos estados e municípios eram repassados e redistribuídos pelo governo federal, limitando na prática a autonomia municipal proposta.

Para Serra (1991, p. 87), essa dificuldade da autonomia municipal, para implementação de programas no nível local, também se deu pela abrangência territorial a que se referia a PNDU de 1975, que era ao mesmo tempo intra e interurbana. Sendo intra-urbana, a ação padecia da ingerência federal em questões locais e sendo interurbana, precisaria da participação de diversos ministérios na estruturação da rede urbana, o que não ocorrreu. 
Steinberger e Bruna (2001, p.47) afirmam que:

"o II PND trazia uma proposta contraditória à economia de mercado, que geralmente privilegiava a concentração de investimentos nos grandes aglomerados urbanos. Para conciliar esse conflito o plano propunha favorecer a criação de pólos secundários, as cidades de porte médio, que se aproveitariam das vantagens das aglomerações. Isso significava apoiar a desconcentração industrial que, de certo modo, já vinha ocorrendo na metrópole de São Paulo, para que essas atividades se distribuíssem pelas demais regiões, conforme seus potenciais de desenvolvimento. Significava também alterar a configuração da rede urbana nacional, fomentando o surgimento de centros preparados para receber essa desconcentração, reassentar a população e estimular, desse modo, o fortalecimento de novas polarizações de atividades econômicas".

As autoras apontam que, "na prática, continuou-se concentrado investimentos nas regiões que dariam maior retorno, como sul e sudeste", e os investimentos intraurbanos ficaram limitados a programas de habitação e saneamento. Os planos diretores desenvolvidos na época se aproximavam mais de instrumentos técnicos e normativos, muitas vezes desconexos da realidade urbana, que tinham pouco ou nenhum rebatimento no desenvolvimento das cidades e na melhoria efetiva da qualidade de vida urbana. Muitos desses planos não tiveram uma força executiva de fato, tornando-se meramente "planos de gaveta".

Já o Relatório técnico do IPEA de Avaliação das Políticas Federais de Desenvolvimento Urbano (SOUZA , 1993) faz uma avaliação positiva de alguns resultados dessa Política, apontando que os ganhos mais expressivos do período 1964/1985 ocorreram na dimensão intra-urbana, quando se realizaram melhoria significativas nas cidades, particularmente em infra-estrutura, pelo menos enquanto a crise econômica não reduziu a capacidade de investimento do setor público. O Relatório afirma ainda que "dimensão interurbana da política jamais foi aceita (e praticada), integralmente, pelas diversas agências intergovernamentais".

Ponto crítico identificado na pesquisa foi o pacto federativo constante em cada uma das PNDUs, ou seja, a capacidade de cooperação e articulação dos entes federados na implementação das políticas urbanas. Verifica-se que fatores críticos desse pacto, como as especificidades do federalismo brasileiro, a guerra fiscal, e a pouca clareza, ou "concorrência" de competências de cada ente federado perante o desenvolvimento urbano, interferem na capacidade de articulação dos três níveis da 
federação não só em propor uma política efetivamente nacional, mas torná-la factível no menor nível da federação, o município.

Apesar de extensa citação, considera-se relevante a transcrição de excerto de LOPES Jr. (2007) que bem relata como transcorria na prática o discurso do "federalismo cooperativo" à época da primeira PNDU:

\begin{abstract}
"A ideologia tecnocrática e centralizadora do regime militar baseava-se num esquema de patronagem estabelecido com os municípios do interior, de maneira a substituir a intermediação das oligarquias pela atuação descentralizada da burocracia federal. A esse modelo hierarquizado que pretendia submeter o clientelismo municipal ao controle da União e neutralizar a atuação desagregadora das oligarquias - a tecnocracia dava o nome de 'federalismo cooperativo'. Esse esquema, pois, não visava prioritariamente a extinção da velha patronagem, e sim, sua adaptação aos planos desenvolvimentistas do regime. Por isso, a extensa e completa malha burocrática e técnica descentralizada ou desconcentrada em empresas, intuições de fomento, autarquias e fundações acabou incorporando, aglutinando o clientelismo sobrevivente. Os chamados 'anéis burocráticos', lócus das demandas paroquialistas, reduziram o poder de barganha dos caciques regionais, aumentaram o controle do executivo sobre o orçamento, mas desgastaram o próprio esquema de cooptação na medida em que impediam a formação, pela via parlamentar, de uma classe ou partido de atuação verdadeiramente nacional. O 'federalismo cooperativo' manteve desnacionalizados os partidos políticos, apesar de ter sido a falta de partidos nacionais o principal argumento contra o multipartidarismo favorável ao Al-3 e aprofundou as disparidades regionais, apenas transferindo suas disputas para dentro do Executivo. Como salienta Abrucio, o declínio do modelo unionista-autoritário e início da redemocratização têm como um dos fatores mais importantes o fracasso de tal estratégia (LOPES Jr.,2007, p. 75).
\end{abstract}

Essa engenharia institucional, ou seja, das unificações - e neutralizações partidárias, das relações e trocas entre governos, da unilaterização do processo de tomada de decisões são pontos relevantes da influência da centralização / descentralização política e/ou concentração/desconcentração de poder nas políticas urbanas, por serem determinantes da autonomia, capacidade e suporte dada aos estados e municípios para organizar o desenvolvimento intra-urbano (no caso dos municípios) e inter-urbano (no caso dos Estados e regiões metropolitana) . A capacidade de gestão dada aos governos subnacionais para solucionarem problemas ou determinarem investimentos em suas escalas territoriais, ou seja, a governança - a autonomia e capacidade de gestão - podem ser determinantes do sucesso ou não de uma política nacional de desenvolvimento urbano. 
Tomando como exemplo o caso das regiões metropolitanas, passadas algumas décadas, embora as metrópoles tenham crescido em importância no cenário nacional, e até ampliados e multiplicados os arranjos sob novas formas, a gestão metropolitana não se firmou como instância intergovernamental de gestão dos problemas de interesse comum, mediante os intrincados problemas federativos, ficando até de certa forma à parte da agenda pública nos anos 90 , retornando ao debate, principalmente acadêmico, em tempos mais recentes, como afirma Souza (2003, p. 138). Esses são condicionantes políticos que determinaram o insucesso de parte da estratégia de gestão territorial da PNDU de 1975.

Em momentos diferentes do processo de urbanização, influenciados diretamente pelos condicionantes políticos de cada período e as estratégias de desenvolvimento em voga, observa-se que na primeira PNDU o discurso era de integração regional, com forte concentração na questão metropolitana. $\mathrm{Na}$ atual PNDU, observa-se que o foco está claramente na cidade, na questão fundiária e habitacional como forma de garantir a função social da propriedade urbana e a gestão democrática das cidades, por meio de processos participativos e compartilhados de gestão dos problemas urbanos, pelo menos em tese.

Mas os efeitos desse processo histórico podem ser percebidos de vários modos, seja nas políticas federais que privilegiaram "escalas" de atuação (ora metrópoles, ora regiões, ora cidades), seja na disputa interna (inter-regional, interurbana) para atrair a atenção do capital para suas potencialidades. Sintomático disso, por exemplo, é a "guerra fiscal" no contexto da nova Constituição de 1988, que tem levado os governos a disputas por subsídios tributários para atrair investimentos, particularmente depois da Lei de Responsabilidade Fiscal. Essa mesma lei, que dispõe sobre restrição ao endividamento, tem, em diversas situações, limitado a aquisição de recursos onerosos por agentes públicos para o financiamento de programas e projetos para 0 desenvolvimento urbano.

Com isso verifica-se que, uma das interfaces do federalismo com as políticas urbanas, o federalismo fiscal - a forma de distribuição das arrecadações de tributos entre os entes federados - que deveria ser um elemento de "soldagem" para efetivação do "pacto", da aliança federativa, acaba trazendo disputas e negociações infindáveis para acordos do que seja extra-constitucional, ou para sua reforma, num contexto 
recente que tem sido marcado por algumas medidas de "recentralização" fiscal do Governo federal, condicionando repasses aos demais governos a uma determinada aplicação.

Para Serra (1991, p. 87), "o discurso da PNDU - de 1975 - era lateral e periférico à política do governo; por isso, era completamente destituído de instrumentos eficazes de ação, o que permitia ignorar as contradições entre ele e a prática da ação governamental". Por instrumentos eficazes de ação, pode-se entender, por exemplo, maior apoio aos estados na gestão das então recém-criadas regiões metropolitanas, maior autonomia municipal nas decisões sobre os empreendimentos urbanos, legislação de suporte ao uso e regulação do solo urbano mais realista quanto ao enfrentamento das ocupações irregulares crescentes nas periferias metropolitanas, no mínimo, liberdade de expressão sobre as decisões políticas tomadas à revelia de qualquer participação social.

Os atores e suas "preferências" poderiam representar o custo de uma decisão política em caso de oposição, o que não chegou a acontecer tendo em vista os movimentos de repressão que deixou atores sociais à margem dos processos decisórios na PNDU de 1975. Mais tarde, a partir de meados da década de 80, pela continuidade da luta por seu espaço político, atores da sociedade se colocaram como agente de mudança, e acabaram "incluídos", se não ainda de forma efetiva no processo decisório, mas obtendo conquistas parciais até a sua inclusão no processo de formulação da política urbana federal de 2004.

A questão da participação dos atores sociais no processo de tomada de decisões pode ser considerada outro fator de identidade específica de cada PNDU. Observa-se, por exemplo, que a primeira PNDU passa por um processo restrito a técnicos e a uma burocracia estatal num período de centralização política. A nova PNDU, no contexto mais recente, após a abertura política e a "democratização" dos processos decisórios, assume a participação ampla de diversos setores da sociedade e do poder público, na proposição de políticas urbanas para as cidades e regiões. 


\section{III}

Em uma análise geral dos impactos da PNDU de 1975 no desenvolvimento urbano, REIS (1996, p. 43) apontou que os principais objetivos por ela definidos, em princípio corretos, foram negados pela prática: "as áreas de concentração foram as que mais cresceram; a qualidade de vida se deteriorou; a concentração de renda se agravou; a geração de empregos atingiu níveis negativos, os custos de infra-estrutura urbana se elevaram e os investimentos reduziram".

Malgrado as limitações que pesaram à implementação das diretrizes da PNDU, Steinberger e Bruna apontam como contribuições que os planos nacionais e depois a PNDU trouxeram para as formulações de desenvolvimento urbano da época, as seguintes :

i. a agregação e a sistematização dos vários temas que envolvem uma política urbana, até então abordados de uma maneira fragmentada;

ii. a formulação de políticas urbanas nacionais;

iii. a consideração de que uma política urbana vai além da problemática de funcionamento interno das cidades para ir ao encontro da problemática regional, via articulação com a rede de cidades, o que, em última análise, significava propugnar pela implantação de uma política nacional de organização territorial;

iv. buscar a compatibilização de um modelo de ocupação do território com o processo econômico e social, via investimentos públicos e privados, tarefa que caberia aos organismos responsáveis pelo planejamento, coordenação e implantação da política de desenvolvimento nacional.

Souza (2004) também ressalta o caráter "inovador e coerente" da PNDU de 1975, pela contribuição dada à sistematização e politização do pensamento urbano na época. E também destaca alguns efeitos positivos em "inovações no tratamento do sistema urbano", especialmente nas regiões metropolitanas e cidades médias, o programa de transportes entre outros.

Contudo, o planejamento urbano estatal desenvolvido no período (em termos físico-territoriais representado pelos planos diretores) não foi capaz de dar conta das contradições que se agravavam na organização do espaço urbano, que no período entre PNDUs, acabou marcado pela (i) segregação sócio-espacial da cidade, (ii) "metropolização" acéfala e desintegrada, (iii) desenvolvimento regional assimétrico, (iv) e ausência de políticas urbanas associadas a um planejamento nacional efetivo. 
Desde então esses problemas permanecem e se agravam, somados à violência, exclusão social, desemprego, problemas ambientais, fazendo transparecer no projeto atual preocupações bem mais específicas no trato dos problemas urbanos, ou intra-urbanos. O próprio documento da PNDU de 2004 especifica o entendimento do desenvolvimento urbano não somente em termos quantitativos do viés econômico, mas em termos qualitativos de melhoria da qualidade de vida nas cidades - social, ambiental, física, política, cultural etc.

Há três décadas a urbanização era o fenômeno recente a ser trabalhado, em termos de ocupação regional, formação de metrópoles, falta de infra-estrutura nas cidades, prevalecendo um projeto fortemente voltado ao crescimento econômico nas regiões e metrópoles - haja a vista o estabelecimento de diretrizes para cada região na PNDU de 1975. Na PNDU de 2004, a cidade é o foco central de atenção das diretrizes e propostas para o desenvolvimento urbano, que muito mais que um preocupação objetiva e quantitativa, agrega elementos qualitativos das condições de vida da sociedade, que culminam na consagração do "direito à cidade" como razão principal da concepção da nova PNDU.

Na PNDU de 2004, o movimento da Reforma Urbana, militante desde antes da ditadura, tinha o foco claramente intra-urbano dos problemas que se agravaram a longo das décadas de 70 e 80 , ao que o governo respondia com "soluções" massivas de grandes investimentos em habitação e saneamento e "remodelações" urbanas por projetos isolados. Os problemas sociais intra-urbanos reais não foram enfrentados, mas não se deixou de dar atenção ao que tocasse no privilégio ao mercado de terras urbanizadas, como foi a Lei 6766/79, que ainda vigora no contexto da PNDU de 2004.

O problema da fragmentação, segregação e exclusão urbana são frutos não só das contradições sociais que se refletem na luta de classes pela "apropriação do espaço", mas pelas aparentes contradições internas do próprio Estado, que ao mesmo tempo que discursa e inova com um processo participativo de construção da política nacional de desenvolvimento urbano, fundamentada em institutos-jurídicos inovadores como da função social da cidade e da propriedade, ainda encontra-se fortemente engajado com o projeto neoliberal-globalizante e neo-desenvolvimentista de uma economia emergente ainda fortemente voltada a interesses privados de acumulação do capital e com a "dinamização do mercado interno". Essa condição abre espaço a 
programas urbanos descolados da perspectiva de "de fato" provocar alterações qualitativas no atual quadro de crise urbana, metropolitana e regional nacionais.

Mas há que se ressaltar que a nova PNDU, como proposições, como concepção, e até como programas e ações em vias de materialização ou já implementadas, se coloca como um marco da renovação do modo de pensar a cidade, do processo de elaboração de proposições para a política urbana nacional baseado na "pactuação federativa democrática", no esforço de incluir diversos segmentos para o debate, nem que pouco se avance em termos concretos, mas pode-se considerar uma conquista de movimentos populares, técnicos, acadêmicos, que desde à época da PNDU de 1975, já buscavam a inclusão do debate urbano na pauta da agenda nacional de modo sistemático, contínuo e inclusivo.

Martins (2003) entende que o debate atual sobre política urbana no país, aponta para necessidade de união de recursos e ações, do qual o Ministério das Cidades tem sido evidência da importância do "controle social" da ação do Estado pela participação direta da sociedade. Para isso, a autora defende que se impõe o desafio de assegurar formas institucionais e de gestão da cidade, "dentro de um trabalho teórico-reflexivo com a ampliação de espaços políticos e constituição permanente de interlocutores" (p.180).

Para a autora, a constituição da política urbana, "inclui leis, planos e recursos, mas requer, principalmente, a constituição de uma forma de gestão, onde a participação da sociedade, de forma direta, não só é essencial, mas o desdobramento de determinações constitucionais. A importância da construção da política urbana baseia-se na hipótese de que a ação dos municípios, na esfera de sua específica competência, tem um imenso potencial capaz de favorecer ou restringir processos de inclusão social, promovendo ou comprometendo a modernização da sociedade brasileira e o desenvolvimento".

Mesmo em contextos diametralmente opostos em termos de democracia, participação, economia, como nos casos analisados, as dificuldades parecem semelhantes, quando se trata da capacidade dos governos em torná-los políticas efetivas. 
O desafio que se vislumbra na construção da PNDU de 2004, que pode contar com sucessos parciais como leis, programas e políticas aprovadas a partir das suas diretrizes, é que está sujeita aos ciclos quadrienais de sucessão dos governos federais. Até então, contou com uma reeleição a seu favor e resistiu a uma mudança partidária com troca de ministro, mas pode ter seu futuro ameaçado pela incerteza de continuidade do ciclo dessa gestão, e mesmo continuando, pode-se questionar qual o limite da construção democrática da PNDU, qual o limite desse conjunto de proposições em constante avanço, e quando se concretizará em uma Política Nacional de Desenvolvimento Urbano, da fato (implementada) e de direito (tendo seu conteúdo legalmente aprovado como tal.).

Trata-se de problemas estruturais da sociedade e do estado brasileiro, bem expressos nas palavras de MARICATO, então Secretária Executiva do Ministério das Cidades, em entrevista na Revista Brasileira de Estudos Urbanos e Regionais (RBEUR):

(...) Então, a Constituição brasileira exige a cooperação, mas tem-se, ao contrário, guerra fiscal num mesmo nível de governo, assim como imensa disputa ou cooptação, dependendo do partido que está aqui ou ali; ou seja, uma cultura difícil de ser superada. A Constituição brasileira pretendeu descentralizar, mas ao mesmo tempo limitou essa descentralização por meio das competências comuns e concorrentes. Também do ponto de vista econômico existe uma dependência muito grande dos municípios em relação aos demais níveis de governo. Precisamos esclarecer as competências dos diversos entes federativos e decidir se há necessidade de novas leis complementares. Precisamos respeitar as competências já definidas claramente, mas não podemos deixar de reconhecer que a situação das gestões metropolitanas está muito insatisfatória. Todo mundo reconhece isso, inclusive a Comissão de Desenvolvimento Urbano do Congresso Nacional. Já podemos festejar um grande avanço nas relações federativas que foi a aprovação da lei dos Consórcios Públicos, que vai permitir a gestão cooperativa ou compartilhada de municípios, governos estaduais e União sob a égide do direito público. O impacto sobre a administração pública brasileira dessa conquista ainda não está bem assimilado.(...)

Pesam ainda contra o espírito da Constituição o arraigado patrimonialismo e o clientelismo da cultura brasileira, que impede que se aproveite dos instrumentos disponíveis, para transformar os potenciais desejos de participação social em canais abertos à coletividade, não só em vozes, mas em deliberações, em se fazer o caminho inverso ao neoliberal e "desprivatizar" as cidades, democratizar o acesso à terra urbana, desconcentrar investimentos em espaços redundantes, integrar políticas e regiões, e não apenas trabalhá-las isoladamente, cooperar federativamente municípios, estados, governo federal - e não apenas competir. 
E como expresso em relatório recente do Ministério das Cidades (2007) para o PNUD, seguem considerações e questões importantes, não necessariamente para 0 fechamento dessa tese, mas como estimulo à continuidade do debate sobre as Políticas Urbanas Federais:

"De acordo com nossa Constituição Federal a política urbana deve ser, necessariamente, produto resultante de uma cooperação federativa. Mas a questão não é apenas jurídica. O Brasil não tem tradição de pacto federativo e compartilhamento na solução de problemas da esfera pública. Interesses paroquiais se superpõem a interesses gerais.

- Como explicar que metrópoles como São Paulo e Rio de Janeiro, que são maiores do que a maior parte dos países da América Latina, não tenham um organismo de gestão compartilhada para seus 17 e 10 milhões de habitantes, respectivamente?

- Quais as conseqüências econômicas, sociais e ambientais da ausência de uma política metropolitana e de acordos intergovernamentais num mesmo território?

- Qual o custo de tamanha irracionalidade e desarticulação que se escancara na desorganização do transporte coletivo ou no destino do lixo, por exemplo?

- Como garantir que a ação federal supere o clientelismo das emendas parlamentares para constituir regras, prioridades e diretrizes resultantes de indicadores socioeconômicos e territoriais?

- E, o que é mais difícil, como garantir uma proposta que seja duradoura e democrática?

A construção de uma esfera com participação direta, se não dá conta de todos esses problemas, ainda é a forma mais eficaz de perseguir esses objetivos. Ela pode constituir uma forte resistência à extinção de conquistas alcançadas pelo movimento nacional de reforma urbana ao longo dos últimos anos, em especial daquelas garantidas no governo Lula, e forte alavanca para alcançar metas pactuadas. Trata-se da construção de paradigmas que articulam conhecimento técnico e crítico, fruto da produção acadêmica e profissional, com o conhecimento trazido pelos que vivem e produzem a cidade". (MARICATO E SANTOS JR., 2007, p. 19)

Por fim, é necessário ressaltar que as cidades, bases sobre a qual atuam as Políticas de Desenvolvimento Urbano são estruturas que refletem aspectos estruturais da sociedade e carregam o passivo de sua história em seus momentos específicos.

\section{IV}

Diante as considerações colocadas, a título de contribuição para a continuidade do processo reflexivo sobre a essa temática, algumas questões podem ser colocadas: 


\section{QUESTÕES}

- Uma PNDU é de fato imprescindível para o desenvolvimento urbano nacional?

- Os contextos são de fato determinantes no sucesso ou fracasso das PNDUs?

- A centralização ou descentralização faz diferença na implementação das PNDUs?

- A participação determina a maior ou menor efetividade das propostas de uma PNDU?

- A PNDU de 2004 sobrevive aos ciclos sucessórios?

- Os técnicos estão preparados para o governo e o governo para os técnicos, e ambos para enfrentar os problemas reais das cidades, metrópoles e regiões?

Tendo algumas dessas questões já sido contempladas nesse debate final, como os contextos, pressupostos e diretrizes das PNDUs, suas bases referenciais, 0 processo participativo, a autonomia municipal, as regiões metropolitanas, as escalas espaciais, e as perspectivas para a nova PNDU, pode-se formular considerações sintéticas sobre a questão titular da tese:

\section{RAZÕES E LIMITES DAS PNDUS:}

- As razões das PNDUs podem estar fundadas na conjugação ou no embate da técnica e da política, das matrizes do pensamento urbanístico e nas particularidades da ação política estatal em cada momento histórico;

- Os limites das PNDUs podem ser fortemente determinados pelos instrumentos (institucionais, financeiros, legais, técnicos) disponíveis para sua implementação e pelas estruturas urbanas que as suportam em cada período;

- E as possibilidades das PNDUs podem se encontrar na participação efetiva da sociedade nos processos decisórios, na manutenção do diálogo com os instâncias deliberativas, na institucionalidade do Estado, e no suporte entre governos para execução dos programas, projetos e ações decorrentes das diretrizes nacionais para o desenvolvimento urbano. 
E a TESE em si, pode ser sintetizada na idéia de que:

"Ainda que com todas as diferenças de princípios, de condições políticas, de formas de ver o país, há uma base da formação nacional, a tradição do não republicanismo, do clientelismo, que estão imbricadas na cultura brasileira, que se perpetuam seja num contexto autoritário, seja num contexto democrático, somada à coexistência de três níveis de poderes, com certa independência, contando ainda com uma estrutura partidária frágil, que dificultam a viabilidade de estruturação de políticas progressiva e socialmente inclusivas, por meio de práticas participativas, que possibilitem também a construção de um sentimento coletivo de direitos". 
Referências bibliográficas

ABREU, M. de P. (org.), A Ordem do Progresso: Cem Anos de Política Econômica Republicana, 1889-1989, Campus, Rio de Janeiro, 1990.

ABRUCIO, F. L. A coordenação federativa no Brasil: a experiência do período FHC e os desafios do governo Lula. Revista de Sociologia Política, jun. 2005, no. 24, p.4167.

ADEODATO, M.T.P.C. Análise das Estratégias para o Projeto de Incorporação de Princípios e Indicadores da Sustentabilidade em Políticas Públicas no Município de Jaboticabal-SP. 2005. 276f. Dissertação (Mestrado em Engenharia Urbana) Departamento de Engenharia Civil, Universidade Federal de São Carlos, São Carlos.

AFFONSO , R. B. A, A federação no Brasil: impasses e perspectivas. In: AFFONSO, R. B. A. e SILVA, P. L. B. (orgs.) A Federação em Perspectiva. São Paulo, FUNDAP: 1995.

ALFONSIN, B. de M. A política urbana em disputa : desafios para a Efetividade de novos instrumentos em uma perspectiva analítica de direito urbanístico comparado : (Brasil, Colômbia e Espanha). Tese de Doutorado. Programa de Pósgraduação em Planejamento Urbano e Regional. UFRJ. 2008.

ALMEIDA, M. H. T. A Recentralizando a federação? Rev. Sociol. Polít., Curitiba, 24, p. 29-40, jun. 2005.

AMARAL FILHO, J. do. O quadrilátero federalista e o federalismo imperfeito no Brasil. Colloque organisé par le GREITD, l'IRD et les Universités de Paris I (IEDES), Paris 8 et Paris 13. Paris, 2000.

ANDRADE, M. C. A. Geopolítica do Brasil. Ed. Ática: 1989.

ARRETCHE, M.. Federalismo e políticas sociais no Brasil: problemas de coordenação e autonomia. São Paulo em Perspectiva.. 2004, vol.18, n.2, pp. 17-26.

Federalismo e relações intergovernamentais no Brasil: a reforma de programas sociais. Dados. 2002, vol.45, n.3, pp. 431-458.

BACELAR T. "Tania Bacelar explica como e porque o Brasil está mudando" de. 06 de julho de 2008. Disponível <http://bahiadefato.blogspot.com/2008/07/tnia-bacelarexplica-como-e-porque-o.html> Acesso em 20 /01/09.

A Máquina da Desigualdade. Fonte: Le Monde Diplomatique Brasil. Extraído de < http://muitasbocasnotrombone.blogspot.com/2008/02/mquina-dadesigualdade-por-tnia-bacelar.html>. Acesso em: 28.12.2008.

BANCO MUNDIAL. Dynamic Cities as Engines of Growth. WORLD DEVELOPMENT REPORT 1999.2000. 
BARACHO JR. J, A. O. e LIMA, E. M. Competências Legislativas e Materiais no Contexto do Pacto Federativo Brasileiro. Comunicação. Disponível em: 12. 08. 2007.

BELLUZZO, L. G. e MELLO, J. M. C. Reflexões sobre a Crise Atual. In: BELLUZO, L.. G., e COUTINHO, R (orgs.). Desenvolvimento Capitalista no Brasil. Ensaios sobre a Crise. São Paulo: Editora Brasiliense. 1982.

BOMFIM, P. R. A. A ostentação estatística (um projeto geopolítico para o território nacional: Estado e planejamento no período pós-64). Tese de Doutorado apresentada à Faculdade de Filosofia, Letras e Ciências Humanas, USP. 2007.

BONDUKI, N. Curso à distância para ações integradas de urbanização de assentamentos precários. Módulo 1 Política Urbana e Habitacional. Disponível em < http://www.nabil.org.br/publicacoes_ver.php?idConteudo=457> Acesso em: 24.06.2010.

BORJA, P. Elaboração de Plano de Saneamento Básico: pressupostos, princípios, aspectos metodológicos e legais. Documento conceitual. Minuta para discussão. Secretara de Saneamento Ambiental. Ministério das Cidades: Brasília, 2008

BRAGA, R. Política urbana, política fiscal e pacto federativo: limites e perspectivas do Estatuto da Cidade no contexto da reforma do Estado. Anais do VII Seminário Internacional da Rede Ibero-americana de Investigadores sobre Globalização e Território. IPPUR-UFRJ, Rio de Janeiro, 25 a 28 de maio de 2004.

BRASIL. Constituição da República Federativa do Brasil. Brasília. 1967. Constituição da República Federativa do Brasil. Brasília. 1988.

CAMPOS FILHO, C. M. Cidades brasileiras - Seu controle ou o caos. São Paulo: Nobel, 1999.

CARNOY, M. Estado e Teoria Política. Campinas: Papirus,1988.339p.

CASTELLS, M. A Questão Urbana. Rio de Janeiro. Paz e terra: 1983. 590p.

CHOAY, F. O urbanismo: utopias e realidades, uma antologia. 6 ed. Perspectiva. São Paulo, 2005

CINTRA, O. A. Planejando as cidades: política ou não política. In: CINTRA, O. A. e HADDAD, P. R. (orgs.). Dilemas do Planejamento Urbano e Regional. Zahar, Rio de Janeiro, 1978.

COSTA, G. M. Prática e ensino em planejamento (urbano) no Brasil: da "velha" compreensividade multidisciplinar à abordagem transidisciplinar. In: COSTA, G. M., MENDONÇA, J. G (Orgs.). Planejamento urbano no Brasil: trajetória, avanços e perspectivas. Belo Horizonte: C/Artes, 2008.

DA MATA, D. DEICHMANN U, HENDERSON, J. V, LALL, SOMIK V. W., HYOUNG G. Examining the growth patterns of Brazilian cities. Texto para Discussão No 1113. IPEA: Brasília, 2005. 
DAIN, S. e LESSA, C. Capitalismo Associado: algumas referências para o Tema Estado e Desenvolvimento. In: BELLUZO, L.. G., e COUTINHO, R (orgs.). Desenvolvimento Capitalista no Brasil. Ensaios sobre a Crise. São Paulo: Editora Brasiliense. 1982.

DANIEL, C. Poder Local no Brasil Urbano. In: Espaço \& Debates: Revista de Estudos Urbanos e Regionais. Ano VIII, № 24, São Paulo: NERU, 1988, p. 26-39.

DEAK, C.; SCHIFFER, Sueli R. (org). O processo de urbanização no Brasil. São Paulo: FUPAM/EDUSP, 2004.

ELAZAR, D. Self-Rule/Shared Rule: Federal Solutions to the Middle East Conflict. Lanham: University Press of America. 1984.

FERNANDES, C. L. M E MEDEIROS, C.M. O Elemento regional no Processo Nacional de Desenvolvimento. In C CINTRA, A. O. e HADDAD, P. R. Dilemas do Planejamento Urbano e Regional no Brasil. Rio de Janeiro: Zahar, 1978.

FERNANDES, E. Reforma urbana e reforma jurídica no Brasil: duas questões para reflexão. In COSTA, G. M. e JUPIRA G. de M. (orgs) Planejamento urbano no Brasil: trajetória, avanços e perspectivas, Belo Horizonte C/Arte. 2008

FEST, F. D. C. Projeto Cura - complementação urbana e mudanças espaciais. Dissertação de Mestrado. PROURB/ FAU/ UFRJ. 2005.

FRANCISCONE, J. G. e SOUZA, M. A. A. de, (1976). Política Nacional de Desenvolvimento Urbano - estudos e proposições alternativas. Série Estudos para o Planejamento, 15, Brasília: IPEA/IPLAN-CNPU

FRIEDMAN, J. R. Regional Development Policy. A case study of Venezuela. Cambridge, 1966.

FURTADO, F. Instrumentos para a gestão social da valorização da terra: fundamentação, caracterização e desafios. In: Financiamento das Cidades: Instrumentos Fiscais e de Política Urbana - SEMINÁRIOS NACIONAIS / Organizadoras: Eglaísa Micheline Pontes Cunha, Claudia M. De Cesare. - Brasília: Ministério das Cidades, 2007. 292 p. : il, $24,5 \mathrm{~cm}$

GIRARDI, P. E. Proposição teórico-metodológica de uma cartografia geográfica crítica e sua aplicação no desenvolvimento do atlas da questão agrária brasileira . Tese de doutorado. Departamento de Geografia UNESP. 2008.

GOLDENSTEIN, L. Repensando a dependência. Editora Paz e Terra. Rio de Janeiro:1994.

GOUVÊA, D.. RIBEIRO, S. Revisão da Lei Federal no 6766/79 - novas regras no "jogo" da cidade? Disponível Em $<$ http://cinder.artisoftware.com/wpcontent/uploads/file/DocumentosFortaleza/Gouvea.pd $\mathrm{f}>$ Acesso em: 05.05.2010.

GRAU, E. R. O Direito Posto e o Direito Pressuposto. Malheiros Editora, São Paulo. 1996. 
GRAZIA, De G. Reforma Urbana e Estatuto da Cidade. Belo Horizonte: EGFJP. 2001.

HARVEY, D. Do gerenciamento ao empresariamento: a transformação da administração urbana no capitalismo tardio. Espaço e Debates, n.39, São Paulo: NERU, 1996, p. 48-65.

J. C. de F. F.. São Paulo e seu Futuro: antes que seja tarde demais. In: AMARAL. Rio de Janeiro, IBAM, 1976,p. 63.

KOHLSDORF, M. E. Ensaio sobre o pensamento urbanístico. Brasília, 1996.

. Planejamento urbano no Brasil, um percurso histórico - do Estado Novo ao estado de exceção. Brasília, dezembro de 1976. (Revisado em março 2002 por NARA KOHLSDORF).

LEITÃO, K. O. A dimensão territorial do Programa de Aceleração do Crescimento: um estudo sobre o PAC no Estado do Pará e o lugar que ele reserva à Amazônia no desenvolvimento do país. Tese de Doutorado. Faculdade de Arquitetura e Urbanismo (USP).São Paulo, 2009.

LEMGRUBER, A. T. Federalismo Fiscal no Brasil: Evolução e Experiências Recentes. Secretaria da Receita Federal. Disponível em < http://www.marcoscintra.org/DOWNLOAD/FederalismoFiscalnoBrasilLemgruberSRF> Acesso em 01.05.09.

LOPES Jr, E. M. A judicialização da política no Brasil e o TCU. FGV Editora:. Rio de Janeiro, 2007.

LUCCHESE, M. C. Curam-se cidades: uma proposta urbanistica da decada de 70. Dissertação de mestrado. São Paulo, FAU-USP, 2004.

MACARINI, J. P. A política econômica do governo Costa e Silva 1967-1969. Rev. econ. contemp. 2006, vol.10, n.3, pp. 453-489. ISSN 1415-9848.

MACDOWELL, C. Financiamento urbano no Brasil: um olhar sobre as finanças municipais Financiamento das Cidades: In.: Instrumentos Fiscais e de Política Urbana - SEMINÁRIOS NACIONAIS / Organizadoras: Eglaísa Micheline Pontes Cunha, Claudia M. De Cesare. - Brasília: Ministério das Cidades, 2007.

MARICATO, E. O desenvolvimento urbano democrático como utopia - Entrevista. Revista Brasileira de Estudos Urbanos e Regionais, v. 6, n. 2. ANPUR: Rio de Janeiro, 2006a.

O ministério das cidades e a política nacional de desenvolvimento urbano. IPEA - políticas sociais - acompanhamento e análise | 12 | fev. 2006b

. SANTOS Jr., O. A. S. Construindo a Política Urbana: participação

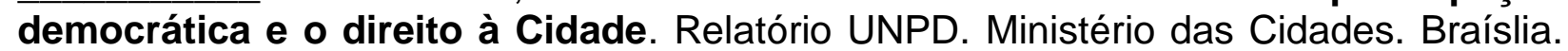
2007.

. Metrópole na Periferia do Capitalismo: ilegalidade, desigualdade e violência. São Paulo: Editora Hucitec, 1996. 
. O Estatuto da Cidade Periférica. São Paulo, 2010.

MARQUES, E. C. Redes sociais e poder no estado brasileiro. Rev. bras. Ci. Soc., Oct., vol.21, no.60, p.45-67. 2006.

. Notas críticas à literatura sobre Estado, Políticas Estatais e Atores Políticos. In: BIB: Revista Brasileira de Informação Bibliográfica em Ciências Sociais. Rio de Janeiro: DUMARÁ, 1997. p. 67-102.

MRTINS, M. L. R. . O Estatuto da Cidade, Marco Referencial para a Política Urbana. CADERNOS DO IJB - NO 1. Osasco, 2004.

. São Paulo: além do Plano Diretor. 17 (47): 167-86, 2003.

MINISTÉRIO DAS CIDADES. Cadernos MCidades № 1: Política Nacional de Desenvolvimento Urbano. Brasília, 2004a.

. Cadernos MCidades № 3 . Planejamento Territorial Urbano e Política Urbana. Brasília: Ministério das Cidades, 2004b. 103 p.

. Cadernos MCidades № 4 . Política Nacional de Habitação. Brasília:

Ministério das Cidades, 2004c. 103 p.

. Cadernos MCidades № 5 - Saneamento Ambiental. Brasília, $2004 f$.

.. Cadernos MCidades № 6. Política Nacional de Mobilidade Urbana

Sustentável. Brasília: Ministério das Cidades, 2004d. 70 p.

.Cadernos MCidades № 7 - Trânsito, questão de cidadania. Brasília,

2004 e.

Brasília, 2006.

Conselho das Cidades: Um Exercício de Gestão Democrática.

- Brasília, 2009 . 129p.

.Resoluções da $2^{a}$ Conferência Nacional das Cidades. Disponível em: www.cidades.gov.br. Acesso em 15.12.2008a.

.Resoluções da 3a Conferência Nacional das Cidades. Disponível em: www.cidades.gov.br. Acesso em 15.12.2008c.

.Resultados, projeções e ações. Brasília: MCidades, 2006. 82 p.

Brasília. 2008b.

.Texto preparatório para a realização da $3^{\text {a }}$ Conferência das Cidades.

.Texto-base para a $2^{\mathbf{a}}$ Conferência Nacional das Cidades. Brasília. 2005. 
MINISTÉRIO DO INTERIOR. Secretaria Geral. II Plano Nacional de Desenvolvimento; programa de ação do governo na área do desenvolvimento, 1975-79. Brasília, 1975.

MIYAMOTO, S. Geopolítica e poder no Brasil. Editora: Papirus, Campinas, 1995. 257 p.

MONTE-MÓR, R.L. Do urbanismo à política urbana: notas sobre a experiência brasileira.In: COSTA, G. M., MENDONÇA, J. G (Orgs.). Planejamento urbano no Brasil: trajetória, avanços e perspectivas. Belo Horizonte: C/Artes, 2008.

MOURA, R. Trajetória e perspectiva da gestão das metrópoles. In: COSTA, G. M. e MENDONÇA, J. G. (org.) Planejamento Urbano no Brasil. Trajetórias, avanços e perspectivas. Belo Horizonte: C/Arte, 2008.

NATAL, J. L.A. Agudização do problema federativo e esgotamento do padrão de desenvolvimento do Brasil. Espaço e Debates: Revista de Estudos Regionais e Urbanos, n.39, São Paulo: NERU, 1996, p. 65-74.

NEVES, L. A.; RIBEIRO, J. M.. Consórcios de saúde: estudo de caso exitoso. Cad. Saúde Pública, Rio de Janeiro, 22(10):2207-2217, out, 2006.

NUNES, L. A. de P.. A construção da esfera pública no planejamento urbano. Cadernos metrópole. 21 pp. 233-245 10 sem. 2009

OLIVEIRA, E. L. de. Demanda futura por moradias no Brasil 2003-2023: uma abordagem demográfica. Brasília: Ministério das Cidades, 2009

OLIVEIRA, F. A crise da federação: da Oligarquia à Globalização. In: AFFONSO, R. B. A. e SILVA, P. L. B. (orgs.) A Federação em Perspectiva. São Paulo, FUNDAP: 1995.

NERU, 1982, p. 36.

O Estado e o urbano no Brasil. Espaço e Debates, n.6, São Paulo:

PALERMO, Vicente. Como se Governa o Brasil? O Debate sobre Instituições Políticas e Gestão de Governo . Dados vol.43 no.3 Rio de Janeiro : 2000.

PERROUX, F. A Economia do Século XX. Lisboa : Herber, 1967.

PINTO, Sol Garson Braule. Regiões metropolitanas:obstáculos institucionais e fiscais à cooperação em políticas urbana. IPPUR, 2007

PIQUET, R . P da S., RIBEIRO, A. C. T . Tempos, Idéias e Lugares: O Ensino do Planejamento Urbano e Regional no Brasil. R. B. Estudos Urbanos e Regionais V.10, N.1. ANPUR. Rio de Janeiro, 2008.

PÓLIS, INSTITUTO. Estatuto da Cidade - guia para implementação pelos municípios e cidadãos. São Paulo: Instituto Polis, 2001.

PRADO, Sérgio. Equalização e federalismo fiscal: uma análise comparada . Konrad Adenauer. Rio de Janeiro, 2006. 
REIS FILHO, N. G. Urbanização e planejamento no Brasil, 1960-1983. CADERNOS DE PESQUISA DO LAP - Universidade de São Paulo, no. 11, jan-fev 1996.

REZENDE, Flávio da Cunha. Por que reformas administrativas falham?. Rev. bras. Ci. Soc. [online]. 2002, vol.17, n.50, pp. 123-142. ISSN 0102-6909.

RIBEIRO, A. C. T. A cidade do Rio de Janeiro: lembrando a "jangada da pedra", de Saramago. In: PIQUET (Org.) Rio de Janeiro: perfis de uma metrópole em mutação. Rio de Janeiro, 2000.

O Ensino do Planejamento Urbano e Regional. R. B. Estudos Urbanos E Regionais, V.4, N.1/2 - Maio/Novembro 2002.

ROBSBAWN, E. A Era dos Extremos: o breve século XX 1914-1991. São Paulo: Cia das Letras. 1995.

RODRIGUES, E. BARBOSA, B. R. Movimentos populares e o Estatuto da Cidade. 2010

ROLNIK, R. O que é cidade. Brasília: Ed. Brasiliense,1988.

ROLNIK, R. Planejamento Urbano nos Anos 90: novas perspectivas para velhos temas. In: Luís Ribeiro; Orlando Júnior. (Org.). Globalização, Fragmentação e Reforma Urbana - O futuro das cidades brasileiras na crise. Rio de Janeiro: Civilização Brasileira, 1994.

SAULE Jr, $\mathrm{N}$ (org.). A Perspectiva do direito à cidade e da reforma urbana na revisão da lei do parcelamento do solo- São Paulo: Instituto Pólis, 2008. 112p. (Cadernos Pólis; 10).

\section{A Participação dos Cidadãos no Controle da Administração}

Pública. Polis Papers. Instituto Polis. São Paulo, 1998

SCHERER, R. Notas sobre planejamento e método. CADERNOS DE PESQUISA DO LAP - Universidade de São Paulo. № 10, nov - dez ,1995.

SCHMIDT, B. V. O Estado e a Política Urbana no Brasil. Editora da Universidade. Porto Alegre, 1983.

SCHUMPETER, Joseph. Capitalismo, socialismo e democracia. Rio de Janeiro: Zahar Editores, 1984.

SCHWARTZ, R. As idéias fora do lugar. Disponível em <http://www.usp.br/fau/depprojeto/labhab/>. Acesso em: 11 de set. 2006.

SERRA, G. Urbanização e centralismo autoritário. Nobel/Editora da Universidade de São Paulo. 1991.

SILVA, J. A.. Direito Urbanístico Brasileiro. 2 ed. São Paulo: Malheiros, 1997

SILVA, M. S. Teoria do federalismo fiscal: notas sobre as contribuições de Oates, Musgrave, Shah e Ter-Minassian. Nova Economia. Belo Horizonte_15 (1)_117137 janeiro-abril de 2005. 
SOUZA, C. Regiões Metropolitanas: Condicionantes Do Regime Político. Revista Lua Nova, № 59. 2003

SOUZA, E. B. Sugestões para uma nova política de saneamento. In: Para a Década de 90. Brasília, IPEA/IPLAN, 1990

. (org). . As Políticas Federais de Desenvolvimento Urbano no Biênio 1989/1990 . . Texto para discussão IPEA. Brasília, IPEA / 1993.

SOUZA, EDGAR BASTOS DE, DILMA SELI PENA PEREIRA, ALDO MOREIRA LIMA E EMMANUEL CAVALCANTE. Avaliação das Políticas Federais de Desenvolvimento Urbano, Habitação e Saneamento em 1991. Texto para discussão IPEA no 304. Porto / Brasília, IPEA / 1993.

SOUZA, M. A. A. O II PND e Política urbana Brasileira: uma contradição evidente. In: DEAK, C.; SCHIFFER, Sueli R. (org). O processo de urbanização no Brasil. São Paulo: FUPAM/EDUSP, 2004. p. 111-144.

STEINBERGER, M. e BRUNA, G. C. Cidades médias: elos do urbano-regional e do público-privado. In. In: ANDRADE T. A.; SERRA, R. V. (Org.). Cidades Médias Brasileiras. Rio de Janeiro: Instituto de Pesquisa Econômica Aplicada - IPEA, 2001, v. 1, p. 35-77.

STÜR, W. B. El desarollo regional en America Latina - Experiencia e Perspectivas. Buenos Aires:Ed. SIAP, 1972,

TOLOSA, H. Os Novos Desafios da Política Urbana na Era do Real. Planejamento e Políticas Públicas. № 15 . IPEA. 1997.

VAINER, C. B. As Escalas do poder e o poder das escalas: o que pode o poder local?. IX Encontro Nacional da ANPUR. 2001.

Fragmentação e Projeto Nacional: Desafios para o Planejamento Territorial. XII Encontro da Associação Nacional de Pós-Graduação e Pesquisa em Planejamento Urbano e Regional, Belém, 2007.

VILLAÇA, F Uma contribuição para a história do planejamento no Brasil. In: DEAK, C.; SCHIFFER, Sueli R. (org). O processo de urbanização no Brasil. São Paulo: FUPAM/EDUSP, 2004.

. Espaço intra-urbano. São Paulo, Studio Nobel, 2001.

WEBER, A. The theory of the location of industries. Chicago: University of Chicago, 1929.

WESTPHAL, J.,Federalism in the United States: Nation Centered Power. In: . AFFONSO , R. B. A. e SILVA, P. L. B. (orgs.) A Federação em Perspectiva. São Paulo, FUNDAP: 1995. 


\section{Biblografia E FONTES CONSULtADAS}

ALBUQUERQUE, M. C. A. A participação da sociedade na redefinição de políticas de direitos.Os direitos da infância e o direto à moradia. Tese de doutorado apresentada ao Programa de pós-graduação em Integração da América Latina da Universidade de São Paulo - PROLAM/USP. 2007.

ANASTASIA, F. Federação e relações intergovernamentais. In: AVELAR, L (org.). Sistema político Brasileiro: uma introdução. $2^{\underline{a}}$ Ed. Fundação Konrad Adenauer e UNESP editora: 2007.

ARRETCHE, Marta. Quem taxa e quem gasta: a barganha federativa na federação brasileira. Rev. Sociol. Polit., jun., no.24, p.69-85. ISSN 0104-4478. 2005.

COSTA, V. Federalismo. In: AVELAR, L e CINTRA, A. O. (org.). Sistema político brasileiro: uma introdução. $2^{\mathrm{a}} \mathrm{Ed}$. Fundação Konrad Adenauer e UNESP editora: 2007.

DAHL, R. Poliarquia. participação e oposição. São Paulo : Edusp. 1997.

FERREIRA, J, S. W. Instrumentos urbanísticos. Notas de aula. Disponível em $<$ http://www.usp.br/fau/docentes/depprojeto/c_deak/CD/4verb/instrumentos-

urb/index.html> Acesso em 09.06.2010

HARVEY D. Social justice and the city. Edward Arnold, Londres, 1973. (Hucitec, São Paulo, 1980)

IMMERGUTT, E. M . As Regras do Jogo: A lógica da política de saúde na França, na Suíça e na Suécia. in: Revista Brasileira de Ciências Sociais, (30) 11: 139-63. 1996.

LAMPARD, E. Aspectos históricos da urbanização. In: HAUSER, Philip Morris, et alli. Estudos de Urbanização, Rio de Janeiro: Pioneira Editora, 1975.

MARQUES, E. C. Redes sociais e instituições na construção do Estado e da sua permeabilidade. Rev. bras. Ci. Soc., Oct., vol.14, no.41, p.45-67. 1999.

MINISTÉRIO DAS CIDADES. Diagnóstico dos Serviços de Água e Esgoto. Secretaria Nacional de Saneamento Ambiental, Programa Nacional de Modernização do Setor de Saneamento. Programa de Sistema Nacional de Informações Sobre Saneamento - SNIS. 2008.

www.cidades.gov.br.

- Publicações e relatórios sobre as conferências. Disponíveis em

. Visão Geral da Prestação dos Serviços de Água e Esgotos. Secretaria Nacional de Saneamento Ambiental, Programa Nacional de Modernização do Setor de Saneamento. Programa de Sistema Nacional de Informações Sobre Saneamento SNIS.2004. 
Regimento do Conselho das Cidades. Homologado pela Resolução Normativa no 02, de 08 de junho de 2006, e alterado pela Resolução Normativa oㅡ 07, de 02 de abril de 2008.

SKOCPOL, T. Bringing the State Back. In: in Peter Evans, Theda Skocpol, and Dietrich Rueschemeyer, eds., Bringing the State Back In (Cambridge University Press, 1985.

TSEBELIS, G. Processo decisório em sistemas políticos: veto players no presidencialismo, parlamentarismo, multicameralismo e pluripartidarismo. In: Revista Brasileira de Ciências sociais, 12 (34):89-118. 1997.

VILLAÇA, F. O que todo cidadão precisa saber sobre habitação. Disponível em <http://www.flaviovillaca.arq.br/pdf/cidadao_habita.pdf>Acesso em: 24.06.2010.

\section{FONTES OFICIAIS}

BRASIL. Comitê de Articulação Federativa. <www.portalfederativo.gov.br>

BRASIL. Informações históricas.< https://www.planalto.gov.br/ >

BRASIL. Lei 10.257 "Estatuto da Cidade". 2001

BRASIL. Lei do Saneamento Básico - Lei №. 11.445 de 05 de Janeiro de 2007.

BRASIL. Lei № 1.817, de 1978, sobre o Zoneamento industrial na região Metropolitana de São Paulo.

BRASIL. Ministério da Fazenda. <http://www.fazenda.gov.br/>

BRASIL. Ministério da Integração Nacional. <http://www.integracao.gov.br>

BRASIL. Ministério das Cidades. <www.cidades.gov.br>

BRASIL. Programa de Aceleração do Crescimento. <http://www.brasil.gov.br/pac/> 